\title{
Teloschistaceae (lichenized Ascomycota) from the Galapagos Islands: a phylogenetic revision based on morphological, anatomical, chemical, and molecular data
}

\author{
Frank Bungartz ${ }^{1,2,3^{*}}$, Ulrik Søchting ${ }^{4}$ \& Ulf Arup ${ }^{5}$
}

\section{Article info}

Received: 8 Jul. 2020

Revision received: 23 Sept. 2020

Accepted: 24 Sept. 2020

Published: 29 Dec. 2020

Associate Editor

Camille Truong

\begin{abstract}
The lichen family Teloschistaceae from the Galapagos is revised. Most of the species belong to the Caloplacoideae, two to Teloschistoideae and a few to Xanthorioideae, three subfamilies not validly published, which is remedied here. Four different datasets were analyzed using Bayesian inference. For the bulk of the species, a combined dataset of nrITS, nrLSU and mrSSU was analyzed. Additionally, three analyses were performed using nrITS to further investigate phylogenetic relationships within and between species in each subfamily, and in the genera Xanthomendoza and Squamulea. Four new genera are described: Lacrima, Oceanoplaca, Phaeoplaca, Sucioplaca. Twenty-four species are reported, of which ten are new to science: Caloplaca nigra, Lacrima galapagoensis, Oceanoplaca chemoisidiosa, O. sideritoides, Phaeoplaca tortuca, Squamulea chelonia, S. humboldtiana, S. osseophila, S. oceanica, and Xanthomendoza leoncita. Several new combinations are proposed and three species of Xanthomendoza are reduced to synonymy. Several new combinations and species placed into synonymy do not occur in the Galapagos, but are treated as a consequence of our taxonomic revision. Morphology, anatomy, secondary chemistry, distribution and molecular phylogenetic affiliation are presented for each species and a key is provided. Eight different chemical patterns are quantitatively described based on HPLC analyses. The new genus Lacrima includes L. galapagoensis, a species without vegetative propagules, and two densely isidiate species, $L$. epiphora and L. aphanotripta that are morphologically similar to 'Caloplaca' wrightii. The only species of Galapagos Teloschistaceae that contains xanthones is placed into Huneckia. Oceanoplaca includes two species with the new anthraquinone isidiosin, $O$. isidiosa and $O$. chemoisidiosa, while a third species, $O$. sideritoides, does not contain this secondary metabolite. Phaeoplaca camptidia has previously been reported from Galapagos, but our phylogenetic analysis suggests that it is a new species, here named P. tortuca. An isolated position is occupied by 'Caloplaca' diplacia, which we place in it its own monotypic genus Sucioplaca. Some Galapagos Teloschistaceae can be considered a 'residue' of unresolved Caloplaca s.1., i.e. the corticolous $C$. floridana is possibly related to the saxicolous $C$. nigra, while C. cupulifera can currently not be placed. Squamulea remains particularly problematic and includes S. phyllidizans, that is nested among otherwise unresolved Squamulea species. Based on molecular data, S. phyllidizans is close to 'Huriella'. 'Huriella' flakusii, described from Peru, is confirmed to occur in the Galapagos and the genus is reduced to synonymy with Squamulea. The Squamulea squamosa/subsoluta group remains largely unresolved, but the new species $S$. chelonia, S. humboldtiana, S. oceanica, and S. osseophila are phylogenetically distinct. Foliose Teloschistaceae are represented only by one species, described as Xanthomendoza leoncita, while the only fruticose species, Teloschistes chrysophthalmus and T. flavicans, are cosmopolitan.
\end{abstract}

Key words: Census of Galapagos Biodiversity, Caloplaca, Galapagos Lichen Inventory, Squamulea, taxonomy, identification key, South America, HPLC, secondary metabolites

\footnotetext{
${ }^{1}$ Biodiversity Integration Knowledge Center, Arizona State University, PO Box 874108, Arizona State University, Tempe, AZ 85287-4108, USA

${ }^{2}$ Charles Darwin Foundation for the Galapagos Islands, Puerto Ayora, Ecuador

${ }^{3}$ Instituto Nacional de Biodiversidad (INABIO), Quito, Ecuador
}

\footnotetext{
${ }^{4}$ Section for Ecology and Evolution, Department of Biology, University of Copenhagen, Universitetsparken 15, DK-2100 Copenhagen Ø, Denmark

${ }^{5}$ Biological Museum, Lund University, Box 117, SE-221 00 Lund, Sweden

* Corresponding author e-mail: frank.bungartz@asu.edu
} 


\section{Introduction}

With their bright orange color, many species in the family Teloschistaceae are amongst the most attractive lichens and their conspicuous thalli are not easily overlooked. Teloschistaceae is a large, diverse family, with $>1,000$ known species worldwide (Arup et al. 2013a). In recent decades, the advent of molecular phylogenetic tools revolutionized lichen taxonomy in general and resulted in an improved understanding of species delimitation and phylogenetic structure also in this family. A major synthesis was achieved when Arup et al. (2013a) proposed three distinct subfamilies, Caloplacoideae, Teloschistoideae, and Xanthorioideae. Phylogenetically well-delimited groups are now distinguished at the generic level within these subfamilies. Subsequently, several studies (e.g., Kondratyuk et al. 2017) tended to overemphasize generic splitting, a strategy that led to an unfortunate inflation of genera, some of which will undoubtedly disappear once a consensus on the global phylogeny in the family can been achieved.

Here, we present a regional revision that focuses on the Galapagos Islands. As a result of our research, we formally recognize four new, phylogenetically well-defined genera. Although a global consensus on generic delimitation in the family is still premature, we prefer this strategy to the alternative of not formally recognizing well-supported clades, which, in our opinion, would only add to the taxonomic confusion.

In North and Central America the family has been thoroughly investigated, mostly by Wetmore (Wetmore 1994, 1996, 1997, 1999, 2001, 2003, 2004, 2007a, b, 2009; Wetmore \& Kärnefelt 1998, 1999) and Arup (1992a, b, 1993a, b, 1994, 1995a, b), but in South America the family has received little attention. A monographic treatment for this continent does not exist, and the literature includes only sporadic records (Santesson 1944; Magnusson 1950; Dix 1953; Dodge 1966; Follmann \& Redon 1972; Aptroot 2002, 2015; Kärnefelt et al. 2002; Etayo \& Osorio 2004; Rosato \& Arup 2010; Lumbsch et al. 2011; Fryday \& Øvstedal 2012; Søchting \& Sancho 2012; Søchting et al. 2014; Søchting et al. 2016; Wilk \& Flakus 2017; Wilk 2020). Aptroot \& Cáceres (2016) provide an identification key to all tropical lecanoroid Caloplaca currently known, and Schumm \& Aptroot (2019a, b, c) recently published a worldwide image catalog for species of Caloplaca s.l.

The high diversity of Teloschistaceae combined with the fact that many species are conspicuous may explain why the literature on Galapagos lichens includes a high number of taxon names that were reported from the archipelago at various points in time. However, many taxa have subsequently been refuted so that the most recent checklists (Weber 1986; Elix \& McCarthy 1998) only included six species. With the Galapagos lichen inventory, initiated in 2005 by the Charles Darwin Foundation (CDF), it soon became obvious that this low species number was untenable. A considerable proportion of Galapagos species are not brightly colored, which may explain why these species have been overlooked. The CDF online checklist subsequently added a considerable number of new species that made a more thorough taxonomic revision necessary of the more than 600 specimens of Teloschistaceae collected as part of this inventory.

The results presented here include (1) detailed descriptions of all species now accepted to occur in the Galapagos, (2) an identification key to these species, (3) an overview and discussion of their secondary chemistry, (4) a molecular phylogeny of the family in the Galapagos, and (5) a list of previously cited names clarifying earlier reports.

\section{Material and methods}

\section{Geographic Context of the Species Inventory}

The Galapagos Archipelago includes more than 123 islands in the eastern Pacific Ocean that emerged from volcanic hot spot activity. Geist (1996) first estimated the youngest islands in the west to have emerged $60,000-$ 300,000 years ago, the oldest ones in the east between 2.8-5.6 million years ago, while further east lie volcanoes that are even older submerged seamounts. Due to variation in sea level, the geography of the archipelago has been highly dynamic (Ali \& Aitchison 2014), but revised age estimates suggest the youngest islands may have emerged as late as 35,000 years ago, and the oldest extant islands are approximately 4 million years old, and that 'over the past 5 million years at least 7 major islands have existed within the archipelago' (Geist et al. 2014). Today, fourteen islands are somewhat arbitrarily recognized as principal islands because of their size, while smaller ones are typically grouped along with these major islands because of their geological connection and biogeographic affinities (Snell et al. 1995, 1996). The climate of the Galapagos is generally dry, characterized by a hot and cool season, with prevailing winds from the south and southeast (Trueman \& d'Ozouville 2010). Five principal vegetation zones can be distinguished: coastal, dry, transition, humid and high-altitude dry zone (Tye et al. 2002; Bungartz et al. 2010; Tye \& Francisco-Ortega 2011).

As part of the Galapagos Lichen Inventory, the following islands have been visited and all vegetation zones were surveyed: Isabela (including Volcán Sierra Negra, Volcán Alcedo, Volcán Darwin, Volcán Cerro Azul), Santiago (including Rábida, Bartolomé), Santa Cruz (including Santa Fé, Plaza Sur, Plaza Norte, Roca Gordon, Pinzón), Pinta, Española, Floreana, and San Cristóbal.

Herbarium collections of the inventory are deposited at CDS, and detailed collection information of Galapagos specimens used in this study can be downloaded from the Charles Darwin Foundation (CDF) Collections Database at http://www.darwinfoundation.org/datazone/collections/. Specimens from historic collections in B, COLO, CAS, $\mathrm{FH}, \mathrm{H}, \mathrm{S}$ have also been examined.

\section{Morphology \& Anatomy}

At the Charles Darwin Research Station, specimens were examined with a Zeiss Stemi DV4 dissecting microscope and a Zeiss Imager A1 compound microscope equipped 
with differential interference contrast (DIC). At the University of Copenhagen, an Olympus SZH Dissecting Scope was used to study specimen morphology. Anatomical details were examined using an Olympus BX60 Compound microscope, equipped with DIC. A Nikon DS-Fil camera was used to capture images of handmade sections of apothecia. Ascospores were recorded using the Nikon NIS Elements 3.22 Documentation Software. A minimum of 10 spores from 3 different specimens was measured and the results are presented as follow for the length $\times$ width and the thickness of the spore septum: (minimum-) average \pm standard deviation (-maximum) ( $\mathrm{n}=$ number of ascospores measured).

Macrophotos were taken in the field with a Nikon D300, D7000, and/or D800E, equipped with a $62 \mathrm{~mm}$ Nikkor Micro Lens and an R1C1 macro flash. In the herbarium, the cameras were mounted to a Novoflex macro-table to take images of specimens not captured in the field. Extension tubes were used for photographic magnifications higher than 1:1. Laboratory photos were taken with the camera connected to the software ControlMyNikon 5.2 (http://www.controlmynikon.com/) and all photos were managed with the program PhotoSupreme (http://www.idimager.com/WP/?page_id=20) using the Darwin Core XML schema to embed collection and identification information as XMP metadata (http://owl.phy. queensu.ca/ phil/exiftool/TagNames/DarwinCore.html). Photos were processed with Photoshop CS6.

\section{Secondary Chemistry}

Secondary metabolites of representative specimens from each taxon were analyzed with high performance liquid chromatography (HPLC) following a standard procedure outlined in Søchting (1997). Whenever possible, thalli and apothecia were analyzed separately.

\section{Molecular Studies}

Seventy-four representative specimens of all taxa from the Galapagos (Table 1) were subjected to molecular analysis based on direct PCR (Arup 2006). The internal transcribed spacer regions (nrITS) and the large subunit (nrLSU) of the nuclear ribosomal RNA genes, as well as the small subunit of the mitochondrial ribosomal RNA gene (mrSSU) were amplified with primers ITS1F (Gardes \& Bruns 1993), ITS4 (White et al. 1990), AL1R (Döring et al. 2000), LR5 or LR6 (Vilgalys \& Hester 1990), mrSSU1 (Zoller et al. 1999) and mrSSU7 (Zhou $\&$ Stanosz 2001). The PCR parameters included an initial hold at $94^{\circ} \mathrm{C}$ for $5 \mathrm{~min}$, followed by 40 cycles of denaturation at $94^{\circ} \mathrm{C}$ for $1 \mathrm{~min}$, annealing at $50^{\circ}-54^{\circ} \mathrm{C}(\mathrm{mrSSU})$ or $53^{\circ}-56^{\circ} \mathrm{C}$ (nrITS and nrLSU) for $1 \mathrm{~min}$, decreasing $1^{\circ} \mathrm{C}$ per cycle for the first 6 of 39 cycles (touchdown), and extension at $72^{\circ} \mathrm{C}$ for $3 \mathrm{~min}$. The sequencing was done by Macrogen Inc., South Korea using the same primers as for the PCR. The two resulting strands were assembled using CLC Main Workbench 4.1.2 TM or Geneious 11.1.5. Subsequent alignments were done in the same programs and adjusted manually. Sequences have been submitted to GenBank as indicated in Table 1.
Four different alignments were prepared: (1) a threegene alignment of nrITS, nrLSU and mrSSU (2134 bp) including 89 members of the subfamily Caloplacoideae together with Wetmoreana brouardi and Caloplaca cupulifera of the Teloschistoideae (Fig. 1); (2) an alignment including $66 \mathrm{nrITS}$ sequences (547 bp) from a majority of specimens from the Galapagos (Fig. 2); (3) an alignment of 47 nrITS sequences (552 bp) from the genus Squamulea (Fig. 3); (4) an alignment of 33 nrITS sequences (567 bp) from the genus Xanthomendoza (Fig. 4). Xanthoria parietina and Parvoplaca nigroblastidiata were used as outgroup in the first two and the later two alignments, respectively. Introns and ambiguous regions were manually excluded during the alignment procedure. The alignments of the three different genes were first analyzed separately to check for incongruence between genes. A conflict was assumed to be significant if two different relationships were both supported with posterior probabilities of 0.95 or higher, but none were detected.

Data were analyzed using the program MrBayes 3.2.4 (Ronquist et al. 2012). A suitable model of molecular evolution was selected using the Bayesian Information Criterion (BIC) as implemented in jModeltest ver. 2.1.4 (Guindon \& Gascuel 2003; Darriba et al. 2012), evaluating only the 24 models available in MrBayes 3.2.0 (Ronquist et al. 2012). For the combined analysis, the $\mathrm{SYM}+\mathrm{G}+\mathrm{I}$ model was found to be optimal for the nrITS, the $\mathrm{GTR}+\mathrm{G}+\mathrm{I}$ for the $\mathrm{nrLSU}$ and $\mathrm{HKY}+\mathrm{G}+\mathrm{I}$ for the $\mathrm{mrSSU}$ data set. For the global nrITS data set, SYM+G+I was found to be optimal, while $\mathrm{SYM}+\mathrm{G}$ was found to be optimal for the Squamulea and the Xanthomendoza nrITS datasets. No molecular clock was assumed. Three parallel runs with 2,000,000 generations, starting with random trees and employing 6 simultaneous chains, were executed, of which 5 were incrementally heated with a temperature of 0.10 . Analyses were diagnosed every 1,000 generations in the last $50 \%$ of the tree sample and automatically halted when convergence was reached. Convergence was defined as a standard deviation of splits (of frequency 0.1 ) between runs below 0.01 . Every 1,000th tree was sampled. A majority-rule consensus tree was constructed from the post burn-in tree samples. The consensus trees were visualized using FigTree 1.4.4 and re-drawn in Adobe Illustrator.

\section{Results}

\section{Secondary Chemistry}

The secondary chemistry of Galapagos Teloschistaceae is extremely diverse (Table 2). Three species, viz. 'Caloplaca' floridana, Phaeoplaca tortuca and ' $C$.' nigra do not seem to produce extractable secondary metabolites. In 23 of the remaining species, anthraquinones can at least be found in their apothecia, even though 4 of them have thalli deficient of secondary metabolites, namely Lacrima aphanotripta, L. galapagoensis, Oceanoplaca chemoisidiosa, and $O$. sideritoides. Thalli and apothecia of Sucioplaca diplacia contain no anthraquinones, but only the $\beta$-orcinol depside atranorin and the $\beta$-orcinol depsidones 
Table 1. Sequences used in any of the five analyses. Newly produced in bold, others downloaded from Genbank.

\begin{tabular}{|c|c|c|c|c|}
\hline Species & Country, collector, collectors nr, herbarium & nrITS & nrLSU & $\operatorname{mrSSU}$ \\
\hline Athallia holocarpa & Sweden, Arup L04071, LD & FJ346540 & KC179148 & KC179478 \\
\hline Blastenia ammiospila & $\begin{array}{l}\text { Austria, Søchting US9345, C (nrITS, mrSSU); Norway, Søchting, } \\
\text { 10092, C (nrLSU) }\end{array}$ & KC179413 & KC179161 & KC179491 \\
\hline Blastenia catalinae & Sweden, Arup L06075, LD & FJ866792 & KT291532 & KT291477 \\
\hline Blastenia crenularia & Iceland, Søchting US7523, C & KC179415 & KC179162 & KC179492 \\
\hline Blastenia relicta & Spain, Søchting US9996, C & KC179416 & KC179163 & KC179493 \\
\hline Bryoplaca jungermanniae & Greenland, Søchting US 10451, C & KC179420 & MT952895 & MT952925 \\
\hline Bryoplaca sinapisperma & $\begin{array}{l}\text { Norway, Arup L08184, LD (nrITS, mrSSU); Norway, Arup L08184, } \\
\text { LD (nrLSU) }\end{array}$ & KC179421 & МT952896 & KC179495 \\
\hline \multirow[t]{2}{*}{ Bryoplaca tetraspora } & Antarctica, Søchting US7979, C (nrITS) & KC179422 & - & - \\
\hline & Greenland, Søchting US10480, C (nrLSU, mrSSU) & - & MT952897 & KC179496 \\
\hline Caloplaca cerina & Svalbard, Elvebakk 03:109, TROM & KC179425 & KC179168 & KC179499 \\
\hline Caloplaca chlorina & Denmark, Søchting US7321, C & KC179426 & KC179169 & KC179500 \\
\hline Caloplaca turkuensis & Sweden, Frödén 1909, LD & KC179432 & MT952899 & KC179501 \\
\hline 'Caloplaca' aractina & Czech Republic, Vondrák 6702, PRA & MH104919 & - & MH100773 \\
\hline 'Caloplaca' albolutescens & Sweden, Arup L09030, LD & KC179423 & МT952898 & KC179502 \\
\hline 'Caloplaca' cupulifera 1 & Australia, Vondrák 4910, CBFS & МT967374 & - & - \\
\hline 'Caloplaca' cupulifera 2 & Galapagos, Bungartz 9746, CDS 47063 & МT967375 & - & - \\
\hline 'Caloplaca' cupulifera 3 & Galapagos, Bungartz 6062, CDS 33741 & МТ967376 & - & - \\
\hline 'Caloplaca' cupulifera 4 & Galapagos, Aptroot 63720, CDS 30276 & МT967377 & - & - \\
\hline 'Caloplaca' cupulifera 5 & Galapagos, Bungartz 5407, CDS 29623 & MT967378 & - & - \\
\hline 'Caloplaca' demissa & Italy, Arup L97911, LD & AF353960 & KC179172 & KC179505 \\
\hline 'Caloplaca' erythrocarpa & Italy, Arup L07109, LD & KC179427 & KC179173 & KC179506 \\
\hline 'Caloplaca' floridana 1 & Galapagos, Bungartz 7935, CDS 38445 & МT967379 & - & - \\
\hline 'Caloplaca' floridana 2 & Galapagos, Bungartz 4461, CDS 28547 & MT967380 & - & - \\
\hline 'Caloplaca' floridana 3 & Galapagos, Bungartz 7265, CDS 37749 & МT967381 & - & - \\
\hline 'Caloplaca' haematites & Ukraine, Vondrák 7278, PRA & MH104928 & MH100789 & MH100756 \\
\hline 'Caloplaca' sideritis & USA, South Dakota, Adavita 5073, LD & МT967382 & - & - \\
\hline 'Caloplaca' cf. sideritis & USA, Arizona, Søchting US9866, C & MT967383 & - & - \\
\hline 'Caloplaca' teicholyta & $\begin{array}{l}\text { Denmark, Søchting US11195, C (nrITS, nrLSU); Denmark, } \\
\text { US9772, C (mrSSU) }\end{array}$ & KC179431 & $\mathrm{KC} 179176$ & KC179510 \\
\hline Eilifdahlia dahlii & Australia, Kärnefelt 20043101, LD & KJ021318 & KJ021253 & KJ021279 \\
\hline Eilifdahlia wirthii & Australia, Wirth et al. 05.10.2011, STU & KJ021320 & KJH021255 & KJ021281 \\
\hline Franwilsia kilcundaensis & Australia, Kärnefelt 20047101, LD & KJ021327 & KJ021260 & KJ021287 \\
\hline Franwilsia bastowii & Australia, Kärnefelt 994301, LD & KJ021324 & KJ021257 & KJ021284 \\
\hline Gyalolechia arizonica & USA, Arizona, Nash 38931, C & KC179433 & KC179195 & KC179529 \\
\hline \multirow[t]{2}{*}{ Gyalolechia aurea } & Arup L97493, LD (nrITS, mrSSU) & KC179434 & - & KC179530 \\
\hline & Austria, Poelt \& Grube 1993, GZU (nrLSU) & - & KC179196 & \\
\hline Gyalolechia bracteata & Austria, Lutzoni 96.8.30-19, C & AF277668 & MT952900 & MT952926 \\
\hline Gyalolechia canariensis & Canary Islands, Étayo \& Rebolé 17566, C & KC179436 & MT952901 & MT952927 \\
\hline Gyalolechia cranfieldii & Australia, Kondratyuk 20441, LD & KJ021334 & KJ021363 & KJ011293 \\
\hline Gyalolechia flavorubescens & Estonia, Søchting US10127, C & KC179439 & KC179197 & KC179531 \\
\hline Gyalolechia flavovirescens & Russia, Søchting US8648, C & AF353966 & KC179198 & KC179532 \\
\hline Gyalolechia fulgens & $\begin{array}{l}\text { Spain, Søchting US7306, C (nrITS); Sweden, Arup L06206, LD } \\
\text { (nrLSU) }\end{array}$ & KC179440 & KC179199 & - \\
\hline Gyalolechia fulgens & Sweden, Søchting US10586, C (mrSSU) & - & - & KC179533 \\
\hline Gyalolechia gomerana & Spain, Søchting US9653, C & KC179441 & KC179200 & KC179534 \\
\hline Gyalolechia stantonii & USA, California, Wetmore $73334, \mathrm{C}$ & KC179445 & KC179201 & KC179535 \\
\hline Gyalolechia stipitata & Mexico, Søchting US9917, C & KC179446 & KC179202 & KC179536 \\
\hline Huneckia crocina & Argentina, Ferraro et al. 10823, C & МТ967384 & МT952902 & MT952928 \\
\hline Huneckia pollinii 1 & USA, Kansas, Morse 14464, LD & KJ021336 & KJ021265 & KJ021296 \\
\hline Huneckia pollinii 2 & USA, Missouri, Wetmore 84103, LD & KJ021337 & - & - \\
\hline Huneckia pollinii 3 & China, Søchting US9850, C & МT967385 & - & - \\
\hline Huneckia pollinii 4 & Spain, Arup L06051, LD & МТ967386 & - & - \\
\hline Huneckia rheinigera 1 & Australia, Elix 38516, C & МT967387 & - & - \\
\hline Huneckia rheinigera 2 & Australia, Elix 28833, LD (isotype) & KJ021222 & - & - \\
\hline Huneckia wrightii 1 & $\begin{array}{l}\text { Galapagos, Aptroot 63246, CDS } 29981 \text { (nrITS); Miranda 962, CDS } \\
45159 \text { (nrLSU, mrSSU) }\end{array}$ & MT967388 & MT952903 & MT952929 \\
\hline Huneckia wrightii 2 & Galapagos, Aptroot 65379 B, CDS 56220 & MT967389 & - & - \\
\hline Huneckia wrightii 3 & Galapagos, Aptroot 64966, CDS 31546 & MT967390 & - & - \\
\hline Jasonhuria bogilana & South Korea, KoLRI 120454KT220196 & KT220205 & KT220214 & - \\
\hline Lacrima aphanotripta & Galapagos, Aptroot 65085, CDS 31667 & МT967391 & - & - \\
\hline Lacrima epiphora 1 & Panama, van den Boom 43698, priv. herb. & MT967392 & MT952904 & MT952930 \\
\hline
\end{tabular}


Table 1. Continued.

\begin{tabular}{|c|c|c|c|c|}
\hline Species & Country, collector, collectors nr, herbarium & nrITS & $\operatorname{nrLSU}$ & mrSSU \\
\hline Lacrima epiphora 2 & Galapagos, Bungartz 9396, CDS 46683 & MT967393 & - & - \\
\hline Lacrima epiphora 3 & Galapagos, Bungartz 5167, CDS 29380 & МT967394 & - & - \\
\hline Lacrima epiphora 4 & Panama, van den Boom 43819, priv. herb. & МT967395 & - & - \\
\hline Lacrima epiphora 5 & Galapagos, Aptroot 64755, CDS 31330 & МТ967396 & - & - \\
\hline Lacrima galapagoensis 1 & $\begin{array}{l}\text { Galapagos, Bungartz 4091, CDS } 28055 \text { (nrITS); Ertz 22855, BR } \\
\text { (nrLSU, mrSSU) }\end{array}$ & МТ967397 & MT952905 & MT952931 \\
\hline Lacrima galapagoensis 2 & Galapagos, Aptroot 63688, CDS 30244 & МТ967398 & - & - \\
\hline Lacrima galapagoensis 3 & Galapagos, Aptroot 64892, CDS 31469 & MT967399 & - & - \\
\hline Lacrima galapagoensis 4 & Galapagos, Aptroot 63715, CDS 30270 & MT967400 & - & - \\
\hline Lacrima galapagoensis 5 & Galapagos, Aptroot 65743, CDS 32335 & MT967401 & - & - \\
\hline Lacrima galapagoensis 6 & Galapagos, Bungartz 4715, CDS 28813 & MT967402 & - & - \\
\hline Lacrima galapagoensis 7 & Galapagos, Bungartz 6298, CDS 34510 & MT967403 & - & - \\
\hline Lacrima galapagoensis 8 & Galapagos, Bungartz 4813, CDS 28977 (holotype) & MT967404 & - & - \\
\hline Lacrima sonorae & Mexico, Wetmore 79435, LD & MT967405 & - & - \\
\hline Lacrima sp. & Argentina, Catamarca. Juan Martin Hernandez & МТ967406 & MT952906 & MT952932 \\
\hline Leproplaca chrysodeta & $\begin{array}{l}\text { Sweden, Arup L07107, LD (nrITS, nrLSU); Sweden, Arup L13261, } \\
\text { LD (mrSSU) }\end{array}$ & KC179448 & KC179206 & MT952933 \\
\hline Leproplaca obliterans & $\begin{array}{l}\text { Sweden, Arup L02331, LD (nrITS, nrSSU); Norway Arup L03472, } \\
\text { LD (mrLSU) }\end{array}$ & KC179449 & KC179207 & KC179541 \\
\hline Leproplaca proteus & Sweden, Arup L02339, LD & KC179450 & KT291557 & KT291507 \\
\hline Leproplaca xantholyta & $\begin{array}{l}\text { Austria, Arup L97278, LD (nrITS); Spain, Søchting US9675, C } \\
\text { (nrLSU, mrSSU) }\end{array}$ & KC179451 & KC179208 & KC179542 \\
\hline Marchantiana asserigena & Scotland, Arup L10184, LD & MT967407 & MT952907 & MT952934 \\
\hline Marchantiana occidentalis & Australia, Kärnefelt 20042502, LD & MT967408 & - & KJ021304 \\
\hline Marchantiana queenslandica & Australia, Kalb 27764, CANB & MT967409 & MT952908 & - \\
\hline Oceanoplaca catillarioides & Cape Verde, van den Boom 36365, LD & MT967410 & MT952909 & MT952935 \\
\hline Oceanoplaca caesioisidiata & Cape Verde, van den Boom 36538, LD & MT967411 & MT952910 & - \\
\hline Oceanoplaca caesiosorediata & Cape Verde, van den Boom 36346, LD & MT967412 & MT952911 & MT952936 \\
\hline Oceanoplaca chemoisidiosa 1 & $\begin{array}{l}\text { Galapagos, Bungartz 6436, CDS } 34651 \text { (nrITS, nrLSU); Aptroot } \\
\text { 64354, CDS } 30919 \text { (mrSSU) }\end{array}$ & МT967413 & MT952912 & MT952937 \\
\hline Oceanoplaca chemoisidiosa 2 & Galapagos, Bungartz 3864, CDS 27746 & МT967414 & - & - \\
\hline Oceanoplaca chemoisidiosa 3 & Galapagos, Bungartz 6417,CDS 34632 (holotype) & MT967415 & - & - \\
\hline Oceanoplaca isidiosa 1 & Galapagos, Adsersen, LAM8-1, C & MT967416 & MT952913 & MT952938 \\
\hline Oceanoplaca isidiosa 2 & Galapagos, Bungartz 3838, CDS 27720 & МT967417 & - & - \\
\hline Oceanoplaca isidiosa 3 & Galapagos, Bungartz 3753, CDS 27635 & МT967418 & - & - \\
\hline Oceanoplaca isidiosa 4 & Galapagos, Bungartz 5281, CDS 29497 & МТ967419 & - & - \\
\hline Oceanoplaca isidiosa 5 & Galapagos, Bungartz 6100, CDS 33779 & МТ967420 & - & - \\
\hline Oceanoplaca isidiosa 6 & Galapagos, Aptroot 64719, CDS 31293 & МT967421 & - & - \\
\hline Oceanoplaca isidiosa 7 & Galapagos, Adsersen, LAM8-2, C & МT967422 & - & - \\
\hline Oceanoplaca sideritoides 1 & Galapagos, Ertz 22861, BR & MT967423 & MT952914 & - \\
\hline Oceanoplaca sideritoides 2 & Galapagos, Bungartz 3663, CDS 27481 & МТ967424 & MT952915 & MT952939 \\
\hline Oceanoplaca sideritoides 3 & Galapagos, Bungartz 8459, CDS 41105 & - & MT952916 & MT952940 \\
\hline Oceanoplaca sideritoides 4 & Galapagos, Aptroot 64095, CDS 30656 & MT967425 & - & - \\
\hline Oceanoplaca sideritoides 5 & Galapagos, Bungartz 4457, CDS 28543 & МТ967426 & - & - \\
\hline Oceanoplaca sideritoides 6 & Galapagos, Bungartz 6516, CDS 34733 (holotype) & MT967427 & - & - \\
\hline Oceanoplaca sideritoides 7 & Galapagos, Bungartz 3597, CDS 27415 & МT967428 & - & - \\
\hline Oceanoplaca sp. & Panama, van den Boom 44028, LD & МT967429 & MT952917 & MT952941 \\
\hline Pachypeltis castellana & Denmark, Greenland, Søchting US10500, C & KC179105 & - & - \\
\hline Pachypeltis cladodes & USA, Whyoming, Wetmore 81439, LD & KC179106 & - & - \\
\hline Pachypeltis intrudens & Afghanistan, Soelberg s.n., C & KC179107 & - & - \\
\hline Parvoplava nigroblastidiata & Sweden, Jonsson 5958, LD & KT161986 & - & - \\
\hline Phaeoplaca camptidia 1 & USA, Missouri, Wetmore 83990, LD & МТ967430 & - & - \\
\hline Phaeoplaca camptidia 2 & USA, Kansas, Morse 14420, LD & МT967431 & MT952918 & MT952942 \\
\hline Phaeoplaca ochrolechioides & Australia, Kalb \& Rogers 18982, CANB (holotype) & МT967432 & MT952919 & - \\
\hline Phaeoplaca tortuca 1 & Galapagos, Aptroot 65189, CDS 31773 & МT967433 & - & MT952943 \\
\hline Phaeoplaca tortuca 2 & Galapagos, Aptroot 64699 A, CDS 31273 & МТ967434 & - & - \\
\hline Phaeoplaca tortuca 3 & Galapagos, Bungartz 3644, CDS 27462 (holotype) & MT967435 & - & - \\
\hline Pyrenodesmia alociza & Sweden, Arup L10185, LD & MT967436 & MT952920 & MT952944 \\
\hline Pyrenodesmia chalybaea & Austria, Søchting US9351, C & KC179454 & MT952921 & KC179571 \\
\hline Pyrenodesmia variabilis & $\begin{array}{l}\text { Austria, Arup s.n., LD (nrITS); Sweden, Arup L03134, LD (nrLSU, } \\
\text { mrSSU) }\end{array}$ & AF353963 & KC179234 & $\mathrm{KC} 179572$ \\
\hline Rufoplaca scotoplaca & Sweden, Arup L10032, LD & KC179457 & KC179235 & $\mathrm{KC} 179573$ \\
\hline Rufoplaca sp. & California, Arup L09201, LD & KC179458 & KC179236 & KC179574 \\
\hline
\end{tabular}


Table 1. Continued.

\begin{tabular}{|c|c|c|c|c|}
\hline Species & Country, collector, collectors nr, herbarium & nrITS & nrLSU & $\operatorname{mrSSU}$ \\
\hline Rufoplaca tristiuscula & Norway, Arup L08171, LD & KC179460 & KC179237 & KC179575 \\
\hline Seirophora blumii & Iran, Haji Moniri Al_4, KW & KT456219 & KT456234 & KT456249 \\
\hline Seirophora californica & Mexico, Gaya 03.04.10-9 \& Lutzoni, DUKE & KT291470 & KT291564 & KT291521 \\
\hline Seirophora lacunosa & Kazakhstan, Mober \& Nordin K18:04, LD & KC179465 & KC179243 & KC179582 \\
\hline Seirophora cf. mediterranea & Ukraine, Khodosovtsev s.n. KW 70478 & KT220204 & KT220213 & KT220222 \\
\hline Seirophora scorigena & Lanzarote, Snogerup, S. \& B. 17201, LD & KC179466 & KC179244 & KC179583 \\
\hline Squamulea chelonia 1 & Galapagos, Bungartz 4521, CDS 28607 & МT967448 & - & - \\
\hline Squamulea chelonia 2 & Galapagos, Bungartz 9745, CDS 47062 & МT967449 & - & - \\
\hline Squamulea chelonia 3 & Galapagos, Aptroot 63996A, CDS 30557 & MT967450 & - & - \\
\hline Squamulea chelonia 4 & Galapagos, Bungartz 9251, CDS 46069 & MT967451 & - & - \\
\hline Squamulea chelonia 5 & Galapagos, Bungartz 6146, CDS 34358 (holotype) & MT967452 & - & - \\
\hline Squamulea chelonia 6 & Galapagos, Aptroot 64699 B, CDS no accession number assigned & MT967453 & - & - \\
\hline Squamulea chelonia 7 & Galapagos, Aptroot 63996 B, CDS no accession number assigned & MT967454 & - & - \\
\hline Squamulea flakusii 1 & Peru, Flakus 9263, KRAM & MN108089 & - & - \\
\hline Squamulea flakusii 2 & Galapagos, Bungartz 4131, CDS 28162 & MT967442 & - & - \\
\hline Squamulea flakusii 3 & Galapagos, Bungartz 4157, CDS 28188 & MT967443 & - & - \\
\hline Squamulea flakusii 4 & Galapagos, Aptroot 65261, CDS 31847 & MT967444 & - & - \\
\hline Squamulea galactophylla & Kansas, Morse 10997, LD & KC179122 & - & - \\
\hline Squamulea humboldtiana 1 & Galapagos, Bungartz 5151, CDS 29364 & MT967437 & - & - \\
\hline Squamulea humboldtiana 2 & Galapagos, Bungartz 3581, CDS 27390 & MT967438 & - & - \\
\hline Squamulea humboldtiana 3 & Nevis Island, Caribbean ('West Indies'), Buck 29560, MIN & MT967439 & - & - \\
\hline Squamulea humboldtiana 4 & Galapagos, Bungartz 4711 B, CDS 56235 (holotype) & MT967440 & - & - \\
\hline Squamulea humboldtiana 5 & Galapagos, Bungartz 9985, CDS 47354 & MT967441 & - & - \\
\hline Squamulea kiamae & Australia, Kondratyuk 20480, LD isotype & KC179123 & - & - \\
\hline Squamulea loekoesiana 1 & South Korea, Jayalal et al. 120433, KoLRI & KY614406 & - & - \\
\hline Squamulea loekoesiana 2 & South Korea, Kondratyuk \& Lókös 161904, KoLRI & KY614408 & - & - \\
\hline Squamulea loekoesiana 3 & South Korea, Kondratyuk \& Lókös 161904, KoLRI & KY614409 & - & - \\
\hline Squamulea loekoesiana 4 & South Korea, Oh et al. 130672, KoLRI & KY614407 & - & - \\
\hline Squamulea loekoesiana 5 & South Korea, Kondratyuk \& Lókös 162000, KoLRI & KY614410 & - & - \\
\hline Squamulea oceanica 1 & Galapagos, Yánez-Ayabaca 2023, CDS 48373 (holotype) & MT967445 & - & - \\
\hline Squamulea oceanica 2 & Galapagos, Bungartz 10152, CDS 47571 & MT967446 & - & - \\
\hline Squamulea oceanica 3 & Galapagos, Bungartz 9857, CDS 47195 & MT967447 & - & - \\
\hline Squamulea osseophila & Galapagos, Aptroot 65489, CDS 32078 (holotype) & MT967455 & - & - \\
\hline Squamulea parviloba & Texas, Wetmore 87830, LD & KC179124 & - & - \\
\hline Squamulea phyllidizans 1 & Galapagos, Aptroot 65468, CDS 32057 & MT967456 & - & - \\
\hline Squamulea phyllidizans 2 & Galapagos, Bungartz 4710, CDS 28808 & MT967457 & - & - \\
\hline Squamulea phyllidizans 3 & Galapagos, Bungartz 4158, CDS 28189 & MT967458 & - & - \\
\hline Squamulea squamosa 1 & USA, Arizona, Wetmore 63344, MIN & MT967459 & - & - \\
\hline Squamulea squamosa 2 & USA, Arizona, Wetmore 63266, MIN & MT967460 & - & - \\
\hline Squamulea squamosa 3 & Mexico, Wetmore 79338, MIN & MT967461 & - & - \\
\hline Squamulea squamosa 4 & USA, Arizona, Kärnefelt AM960105, LD & KC179125 & - & - \\
\hline Squamulea squamosa 5 & Mexico, Moberg 8782, UPS & MT967462 & - & - \\
\hline Squamulea 'squamosa 1' & Galapagos, Aptroot 65480, CDS 32069 & MT967463 & - & - \\
\hline Squamulea 'squamosa 2' & Galapagos, Aptroot 65167, CDS 31751 & MT967464 & - & - \\
\hline Squamulea 'squamosa 3' & Galapagos, Bungartz 7428, CDS 37915 & MT967465 & - & - \\
\hline Squamulea subsoluta 1 & Galapagos, Ertz 11884, CDS 37243 & MT967467 & - & - \\
\hline Squamulea subsoluta 2 & USA, Arizona, Moberg 8500, UPS & МT967468 & - & - \\
\hline Squamulea subsoluta 3 & Austria, Arup L97072, LD & AF353954 & - & - \\
\hline Squamulea subsoluta 4 & Canada, Arup L89634, LD & МТ967469 & - & - \\
\hline Squamulea subsoluta 5 & Spain, Llimona et al., BCN 8457 & EU639650 & - & - \\
\hline Sucioplaca diplacia 1 & Galapagos, Ertz 11610, CDS 36936 & MT967470 & MT952922 & МТ952945 \\
\hline Sucioplaca diplacia 2 & Galapagos, Aptroot 64559, CDS 31131 & МT967471 & - & \\
\hline Usnochroma carphinea & France, Roux, 1998, C & KC179468 & KC179259 & KC179598 \\
\hline Usnochroma scoriophila & Tenerifa, 1995, Gomez-Bolea, C & KC179469 & KC179260 & KC179599 \\
\hline Variospora aurantia & Spain, 1998, Llimona, C (nrITS, mrSSU); Italy, 2006, Lange, C (nrLSU) & KC179470 & KC179261 & KC179600 \\
\hline Variospora dolomiticola & Spain, Thell SP0514, LD & KC179471 & KC179262 & KC179601 \\
\hline Variospora flavescens & $\begin{array}{l}\text { Denmark, US9601, C (nrITS); Sweden, Arup L03060, LD (nrLSU, } \\
\text { mrSSU) }\end{array}$ & KC179473 & KC179263 & KC179602 \\
\hline Variospora glomerata & Sweden, Arup L03119, LD & KC179474 & KC179264 & KC179603 \\
\hline Variospora kudratovii & Iran, Zarei-Darki 2779, KW-L & KJ021242 & KJ021274 & KJ0223190 \\
\hline \multirow[t]{2}{*}{ Variospora thallincola } & $\begin{array}{l}\text { Sweden, Søchting US7481, C (nrITS); Sweden, Gaya et al., BCN } \\
\text { (nrLSU) }\end{array}$ & KC179475 & JQ301563 & - \\
\hline & Wales, Arup L92148, LD (SSU) & - & - & KC179604 \\
\hline
\end{tabular}


Table 1. Continued.

\begin{tabular}{|c|c|c|c|c|}
\hline Species & Country, collector, collectors nr, herbarium & nrITS & nrLSU & mrSSU \\
\hline Variospora velana & $\begin{array}{l}\text { Italy, Arup L07194, LD (nrITS); Italy, Arup L07123, LD (nrLSU, } \\
\text { mrSSU) }\end{array}$ & KC179476 & KC179265 & KC179605 \\
\hline Wetmoreana brouardii 1 & Mexico, Gaya 03.03.10-3 \& Lutzoni, DUKE & KT291448 & - & - \\
\hline Wetmoreana brouardii 2 & Mexico, Søchting, US9916, C & MT967472 & - & - \\
\hline Wetmoreana brouardii 3 & Galapagos, Bungartz 4053, CDS 27983 & MT967473 & - & - \\
\hline Wetmoreana brouardii 4 & Galapagos, Aptroot 65107, CDS 31689 & MT967474 & - & - \\
\hline Xanthomendoza alfredii & Russia, Obermayer 50-P3, GZU (holotype) & AM263332 & - & - \\
\hline Xanthomendoza aphrodites & Cyprus, Kalb 1807/15808, Kalb priv. herb. (holotype) & AM408411 & - & - \\
\hline Xanthomendoza borealis & Russia, Zhurbenko 94411, UPS & KC179133 & - & - \\
\hline Xanthomendoza fallax & USA, Søchting US 9566, C & AF353955 & - & - \\
\hline Xanthomendoza fulva & Chile, Region XI, Frödén 1544, LD & KC179134 & - & - \\
\hline Xanthomendoza galericulata & Mexico, Søchting US 9898, C & KC179135 & - & - \\
\hline Xanthomendoza hasseana & USA, Søchting US 7014, C & KC179136 & - & - \\
\hline Xanthomendoza hermonii & Syria, Kondratyuk 20128, LD isotype & KC179137 & - & - \\
\hline Xanthomendoza huculica & Czech Republic, Vondrák 11246, PRA & MH145373 & - & - \\
\hline Xanthomendoza kashiwadanii & Argentina, Frödén xxxx, LD & MT967475 & - & - \\
\hline Xanthomendoza leoncita 1 & Galapagos, Bungartz 4417, CDS 28502 (holotype) & МТ967476 & - & - \\
\hline Xanthomendoza leoncita 2 & Galapagos, Aptroot 64925, CDS 31504 & МТ967477 & - & - \\
\hline Xanthomendoza mendozae & Chile, Søchting US 10209, C & KC179138 & - & - \\
\hline Xanthomendoza montana & USA, Wetmore 80956, M & KC179139 & - & - \\
\hline Xanthomendoza novozelandica & New Zealand, Kärnefelt 999003, LD & KC179140 & - & - \\
\hline Xanthomendoza oregana & Oregon, McCune 31146, LD & KC179141 & - & - \\
\hline Xanthomendoza soechtingii & Russia, Søchting, US6422, C & МT967478 & - & - \\
\hline Xanthomendoza trachyphylla & USA, North Dakota, Wetmore 80270, LD & KC179143 & - & - \\
\hline Xanthomendoza ulophyllodes & Russia, Kuznetsova 2006, H (ITS) & KC179144 & - & - \\
\hline Xanthomendoza weberi 1 & USA, North Carolina, Søchting US7241, C & KC179145 & - & - \\
\hline Xanthomendoza weberi 2 & France, Honegger 114t1, Z+ZT & AM292819 & - & - \\
\hline Xanthomendoza weberi 3 & Peru, Santesson \& Theler P126:7 (S) & MT967479 & - & - \\
\hline Xanthomendoza weberi 4 & USA, Massachusetts, Honegger 350t1, Z+ZT & AM292853 & - & - \\
\hline Xanthomendoza weberi 5 & USA, Delaware, Honegger 57t5, Z+ZT & AM292814 & - & - \\
\hline Xanthomendoza weberi 6 & USA, Kansas, Adavita 2253, LD & MT967480 & - & - \\
\hline Xanthomendoza wetmorei & USA, Iowa, Wetmore 76328, LD & MT967481 & - & - \\
\hline Xanthoria parietina & $\begin{array}{l}\text { Denmark, 2002, Søchting, C (nrITS, mrSSU); Denmark, Søchting } \\
\text { US7157, C (nrLSU) }\end{array}$ & KC179411 & KC179289 & KC179629 \\
\hline Yoshimuria galbina & $\begin{array}{l}\text { South Korea, Arup L15370, LD (nrITS); Arup 15500, LD (nrLSU, } \\
\text { mrSSU) }\end{array}$ & MT967482 & МT952923 & MT952946 \\
\hline Yoshimuria spodoplaca & $\begin{array}{l}\text { South Korea, Wang \& Ryu 110364, KoLRI (nrITS, mtSSU); Arup } \\
\text { L15575, LD (nrLSU) }\end{array}$ & KJ021249 & МT952924 & KJ023194 \\
\hline
\end{tabular}

isofulgidin, vicanicin and caloploicin. Huneckia wrightii is the only species of Galapagos Teloschistaceae with a thallus producing xanthones (lichexanthone), but anthraquinones are found in its apothecia.

Among the anthraquinone patterns detected, chemosyndrome A sensu Søchting (1997) is the most common. It is dominated by almost $100 \%$ parietin, and always with small proportions of teloschistin, fallacinal, parietinic acid and emodin. Chemosyndrome A occurs in Leproplaca chrysodeta, Oceanoplaca sideritoides, and in most specimens of Squamulea, e.g. in the species: S. chelonia, S. flakusii, S. humboldtiana, S. oceanica and S. osseophila. Most of the specimens of the S. squamosa/subsoluta-group are also characterized by chemosyndrome A. Other specimens in Squamulea have a related chemosyndrome, A3, where teloschistin and/or fallacinal occur in significantly higher proportion. The only species in Squamulea that is consistently characterized by chemosyndrome A3 is $S$. phyllidizans (and an obscure sorediate specimen of $S$. subsoluta/squamosa, see comments below), but the chemosyndrome is also found in Wetmoreana brouardii and Xanthomendoza leoncita. Caloplaca cupulifera produces the anthraquinone fragilin, a distinctly chrome-yellow pigment, which is also responsible for the color of Lacrima epiphora and occurs in apothecia of L. aphanotripta and L. galapagoensis. Fragilin can also be present in Oceanoplaca sideritoides in trace amounts. Of particular interest is the presence of an anthraquinone here named isidiosin, after Oceanoplaca isidiosa, a species in which it occurs abundantly. The secondary chemistry of Oceanoplaca isidiosa was earlier studied by Santesson (1970), who detected parietin, emodin, fragilin, but also an unknown tri-chlorinated compound that he called ' 402 ' from its molecular weight, and that could correspond with isidiosin. The structure of this secondary metabolite is still not resolved, but according to Santesson (1970), it was also found in C. albidella, C. brachyloba, Sucioplaca diplacia, C. granulifera, C. melanocheila, C. peragrata and $C$. tenella. These species are all from South America and Hawaii, except for C. granulifera, which occurs on 
Table 2. Secondary metabolites in Galapagos Teloschistaceae based on HPLC analyses. Figures are average values based on the number of samples listed in parentheses. They represent relative proportions of compounds quantified by absorption at $270 \mathrm{~nm}$ wavelength, as described in Søchting (1997). Names of the chemosyndromes are those previously published in Søchting (1997 \& 2001), and Søchting \& Frödén (2002).

\begin{tabular}{|c|c|c|c|c|c|c|c|c|c|c|c|c|c|c|c|c|c|c|c|}
\hline Species & 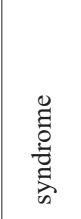 & 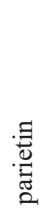 & 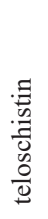 & 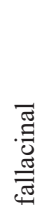 & 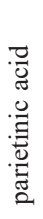 & 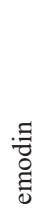 & $\begin{array}{l}\Xi \\
\Xi \\
\Xi \\
\Xi \\
\Xi\end{array}$ & $\begin{array}{l}\Xi \\
\Xi \\
0 \\
0 \\
\frac{1}{1} \\
\frac{1}{1}\end{array}$ & 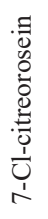 & 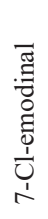 & 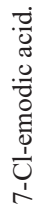 & 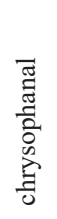 & $\frac{\Xi}{\Xi}$ & 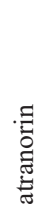 & 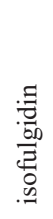 & . & $\frac{\frac{\pi}{0}}{\frac{0}{0}} \frac{0}{\frac{0}{0}}$ & 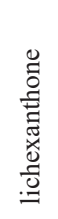 & 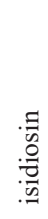 \\
\hline Caloplaca cupulifera (6) thallus & B5 & . & . & . & . & . & 98 & 1 & . & . & 1 & . & . & . & . & . & . & . & . \\
\hline Caloplaca floridana (2) thallus & void & . & . & . & . & . & . & . & . & . & . & . & . & . & . & . & . & . & . \\
\hline Caloplaca nigra (2) apothecia & void & . & . & . & . & . & . & . & . & . & . & . & . & . & . & . & . & . & . \\
\hline Caloplaca nigra (2) thallus & void & . & . & . & . & . & . & . & . & . & . & . & . & . & . & . & . & . & . \\
\hline Huneckia wrightii (5) apothecia & . & . & . & . & . & . & . & . & . & . & . & 14 & 11 & . & . & . & . & 60 & . \\
\hline Huneckia wrightii (6) thallus & $\cdot$ & . & . & . & . & . & $\cdot$ & $\cdot$ & . & . & . & $\cdot$ & $\cdot$ & . & . & . & . & 100 & . \\
\hline Lacrima aphanotripta (1) apothecia & $\mathrm{C} 5$ & . & . & . & . & . & 71 & 25 & . & . & . & . & . & . & . & . & . & $\cdot$ & . \\
\hline Lacrima aphanotripta (1) thallus & void & . & . & . & . & . & & & . & . & . & . & . & . & . & . & . & . & . \\
\hline Lacrima epiphora (3) apothecia & B1 & 23 & 0 & 0 & 0 & 1 & 73 & 1 & . & . & 1 & 0 & 0 & . & . & . & . & . & . \\
\hline Lacrima epiphora $(5)$ thallus & B1 & 19 & . & . & . & 1 & 75 & 3 & . & . & 1 & 0 & 0 & . & . & . & . & . & . \\
\hline Lacrima galapagoensis (6) apothecia & $\mathrm{C} 5$ & 0 & 0 & 0 & 0 & 2 & 45 & 51 & 1 & 1 & 0 & 0 & 0 & . & . & . & . & . & . \\
\hline Lacrima galapagoensis (5) thallus & void & $\cdot$ & . & . & . & . & $\cdot$ & $\cdot$ & . & . & . & . & . & . & . & . & . & . & . \\
\hline Leproplaca chrysodeta (1) thallus & A & 94 & 1 & 3 & 1 & 1 & . & . & . & . & . & . & . & . & . & . & . & . & \\
\hline Oceanoplaca chemoisidiosa (4) apothecia & . & . & . & . & . & . & . & . & . & . & . & . & . & . & . & . & . & . & 100 \\
\hline Oceanoplaca chemoisidiosa (3) thallus & void & . & . & . & . & . & . & . & . & . & . & . & . & . & . & . & . & . & . \\
\hline Oceanoplaca isidiosa (2) apothecia & . & . & . & . & . & . & . & . & . & . & . & . & . & . & . & . & . & . & 100 \\
\hline Oceanoplaca isidiosa (5) thallus & . & . & . & . & . & . & . & . & . & . & . & . & . & . & . & . & . & . & 100 \\
\hline Oceanoplaca sideritoides (2) apothecia & A & 90 & 1 & 2 & 3 & 2 & 2 & 1 & . & . & . & . & . & . & . & . & . & . & . \\
\hline Oceanoplaca sideritoides (2) thallus & void & . & . & . & . & . & . & . & . & . & . & . & . & . & . & . & . & . & . \\
\hline Phaeoplaca tortuca (2) apothecia & void & . & . & . & . & . & . & . & . & . & . & . & . & . & . & . & . & . & . \\
\hline Phaeoplaca tortuca (2) thallus & void & . & . & . & . & . & . & . & . & . & . & . & . & . & . & . & . & . & . \\
\hline Squamulea chelonia (5) thallus \& apothecia & A & 98 & 0 & 1 & 0 & 0 & . & . & . & . & . & . & . & . & . & . & . & . & . \\
\hline Squamulea flacusii (3) thallus & A & 85 & 6 & 7 & 1 & 1 & . & . & . & . & . & . & . & . & . & . & . & . & . \\
\hline Squamulea humboldtiana (1) thallus & A & 89 & 2 & 7 & 1 & 1 & . & . & . & . & . & . & . & . & . & . & . & . & . \\
\hline Squamulea oceanica (2) thallus & A & 95 & 3 & 0 & 1 & 2 & . & . & . & . & . & . & . & . & . & . & . & . & . \\
\hline Squamulea osseophila (1) thallus & A & 96 & 2 & 3 & 0 & 0 & . & . & . & . & . & . & . & . & . & . & . & . & . \\
\hline Squamulea phyllidizans (2) apothecia & A3 & 82 & 3 & 11 & 2 & 1 & . & . & . & . & . & . & . & . & . & . & . & . & . \\
\hline Squamulea phyllidizans (3) thallus & A3 & 67 & 2 & 27 & 3 & 0 & . & . & . & . & . & . & . & . & . & . & . & . & . \\
\hline Squamulea subsoluta A (1) thallus & A & 93 & 2 & 2 & 2 & 1 & . & . & . & . & . & . & . & . & . & . & . & . & . \\
\hline Squamulea subsoluta A3 (3) thallus & A3 & 70 & 8 & 19 & 2 & 1 & . & . & . & . & . & . & . & . & . & . & . & . & . \\
\hline Sucioplaca diplacia (5) thallus \& apothecia & . & . & . & . & . & . & . & . & . & . & . & . & . & 42 & 17 & 17 & 24 & . & . \\
\hline Teloschistes chrysophthalmus (2) thallus & A & 87 & 7 & 4 & 1 & 1 & . & . & . & . & . & . & . & . & . & . & . & . & . \\
\hline Teloschistes flavicans (2) thallus & $\mathrm{A}+2$ & 40 & 2 & 8 & 2 & 1 & . & . & . & . & . & . & . & . & 5 & 14 & 28 & . & . \\
\hline Wetmoreana brouardii (2) apothecia & A3 & 65 & 4 & 27 & 4 & 1 & . & . & . & . & . & . & . & . & . & . & . & . & . \\
\hline Wetmoreana brouardii (3) thallus & $\mathrm{A} 3+3$ & 57 & 3 & 17 & 2 & 0 & . & . & . & . & . & . & . & . & 9 & 13 & . & . & . \\
\hline Xanthomendoza leoncita (1) thallus & A3 & 71 & 3 & 23 & 3 & 0 & . & . & . & . & . & . & . & . & . & . & . & . & . \\
\hline
\end{tabular}

Socotra Island. Galapagos specimens of S. diplacia did, however, not contain isidiosin. In Galapagos, isidiosin has instead been detected in the apothecia of Oceanoplaca chemoisidiosa, a sister taxon to $O$. isidiosa.

Xanthomendoza is represented by a single species, $X$. leoncita, characterized by the chemosyndrome A3. The chemistry of the Teloschistes species in the archipelago does not differ from specimens from the mainland. Teloschistes chrysophthalmus is characterized by chemosyndrome A, while Teloschistes flavicans by chemosyndrome A+2 (Søchting \& Frödén 2002).

\section{Molecular Phylogeny}

The results of our molecular studies are represented in four phylogenetic trees:
The three-gene tree constructed from nrITS, nrLSU and mrSSU sequences represents an overview of the subfamily Caloplacoideae (Fig. 1). This analysis shows how Galapagos Caloplacoideae are nested within the subfamily overall. At the base of the tree are Marchantiana and Yoshimuria. These two genera are sister to a clade that again divides into two principal groups, one with one Galapagos species Leproplaca chrysodeta, and another clade that includes several Galapagos Caloplacoideae from the newly described genera Lacrima, Oceanoplaca, Phaeoplaca, and Sucioplaca.

Figure 2 presents the nrITS phylogeny of Galapagos Caloplacoideae in more detail. Two crustose members of the Teloschistoideae, 'Caloplaca' cupulifera and Wetmoreana brouardii are also included at the base and need 
further study to determine how closely related these two species are. More importantly, the delimitation of genera and species recognized in the three-gene tree (Fig. 1) are confirmed here.

The nrITS phylogeny of the genus Squamulea is presented in Figure 3. Based on ITS sequences, the phylogeny of the genus remains largely unresolved and, in the limited analysis presented here, the genus does not even seem to be monophyletic. To better understand this complex group, further studies using additional genes are necessary. More specifically, an objective assessment of Huriella requires analyzing more genes from more taxa. At the moment, we do not have the necessary data to present such a phylogeny. Nevertheless, our phylogenetic tree presents an overview for the species from the Galapagos and it resolves at least one well-defined group, with three distinct lineages, described here as Squamulea chelonia, S. humboldtiana, and S. oceanica.

The nrITS phylogeny of Xanthomendoza (Fig. 4) illustrates that the new species $X$. leoncita is well-separated from its closest relative, $X$. weberi.

The two fruticose species, Teloschistes chrysophthalmus and T. flavicans, were not included in the phylogenetic trees. Both species also occur on the South American mainland, where the diversity in the genus is much higher.

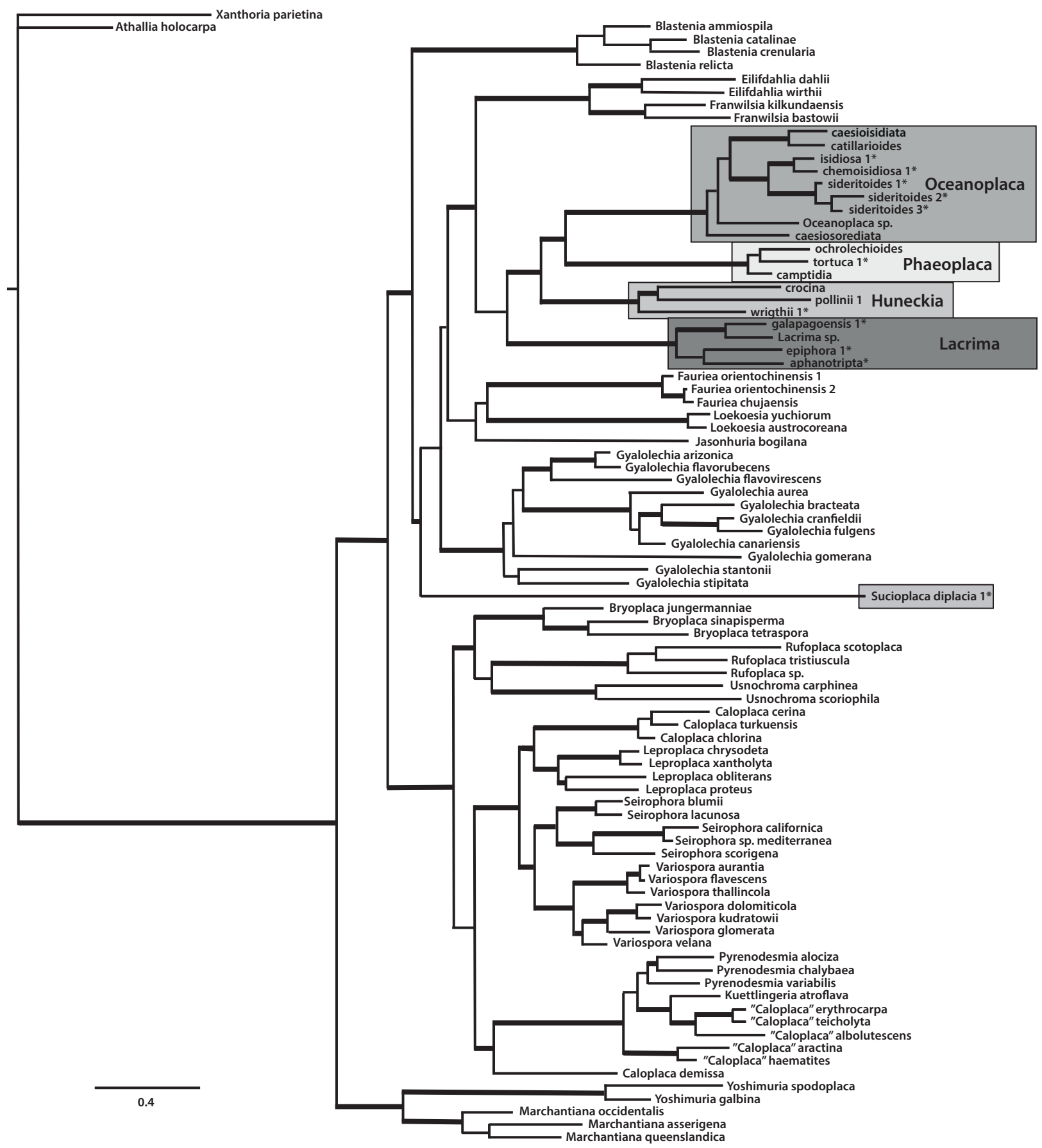

Figure 1. Three-gene tree (nrITS, nrLSU and mrSSU) of the subfamily Caloplacoideae, with the species reported from the Galapagos highlighted. Nodes supported by posterior probabilities higher than 0.95 are in bold. Sequences generated from Galapagos material are marked by an asterisk* 


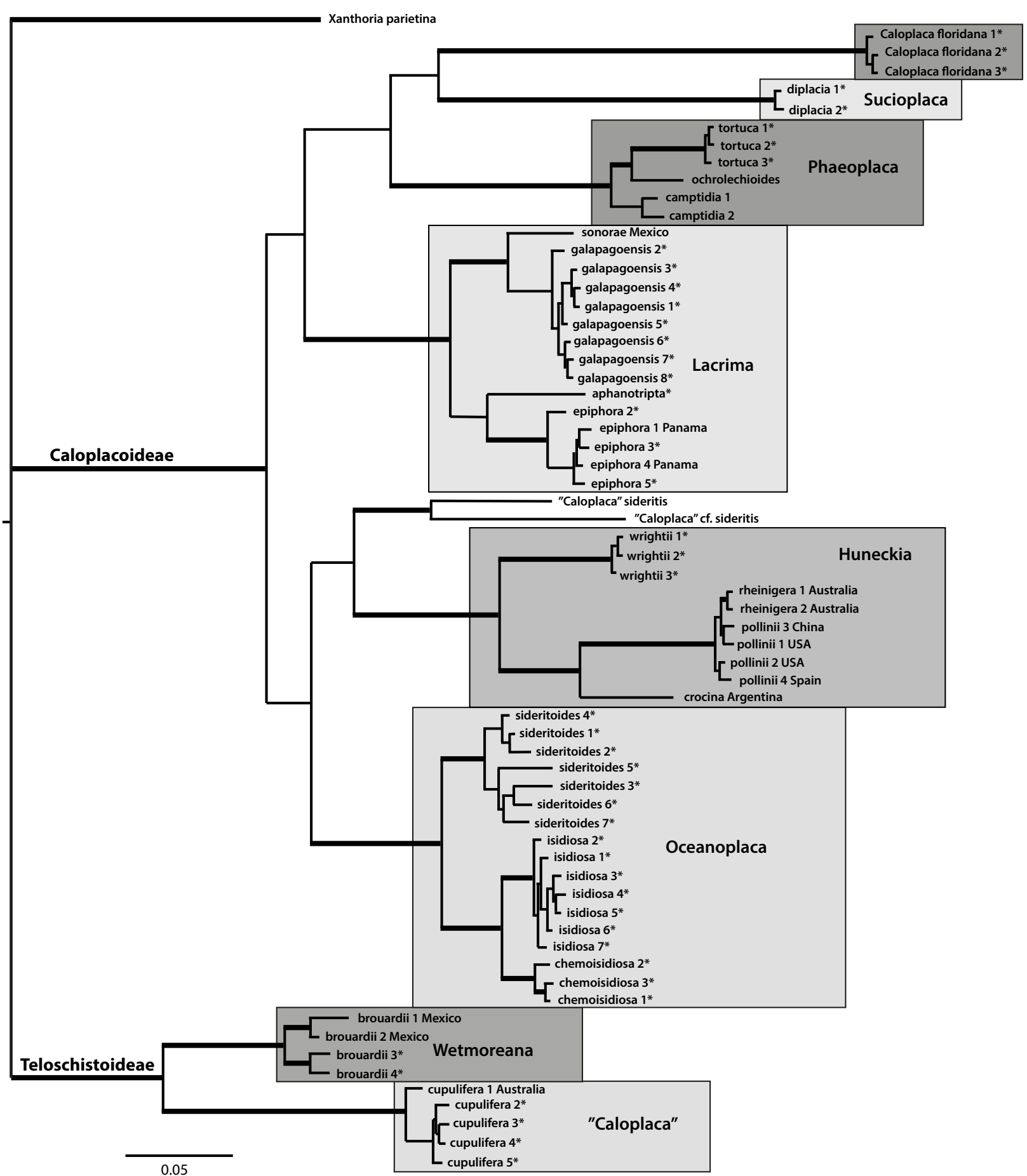

Figure 2. Phylogenetic nrITS tree of species from the subfamily Caloplacoideae and Teloschistoideae in the Galapagos, emphasizing the relationship of the newly described genera Lacrima, Oceanoplaca, Phaeoplaca, and Sucioplaca. Nodes supported by posterior probabilities higher than 0.95 are in bold. Sequences generated from Galapagos material are marked by an asterisk*.

\section{Discussion}

Despite the inclusion of several data sets (nrITS, nrLSU and mrSSU), some phylogenies, particularly for the genus Squamulea, remain poorly resolved. It is likely that several new species are endemic to the Galapagos, but limited material and gaps in molecular data for continental South American taxa at the moment prevent a more comprehensive assessment of the Teloschistaceae, its origins and island biogeography.

The results from our combined analysis of the nrITS,
nrLSU and mrSSU for the subfamily Caloplacoideae reveal several well-supported clades corresponding to the genera currently accepted in this subfamily (Fig. 1). At the bottom of the tree, Marchantiana and Yoshimuria are sister to the rest of the subfamily, which in turn divides into several major subclades.

The first major subclade includes two genera described from the Southern Hemisphere: Eilifdahlia and Franwilsia. Both form a well-supported group, but to our knowledge, none of these species occur in the Galapagos. 


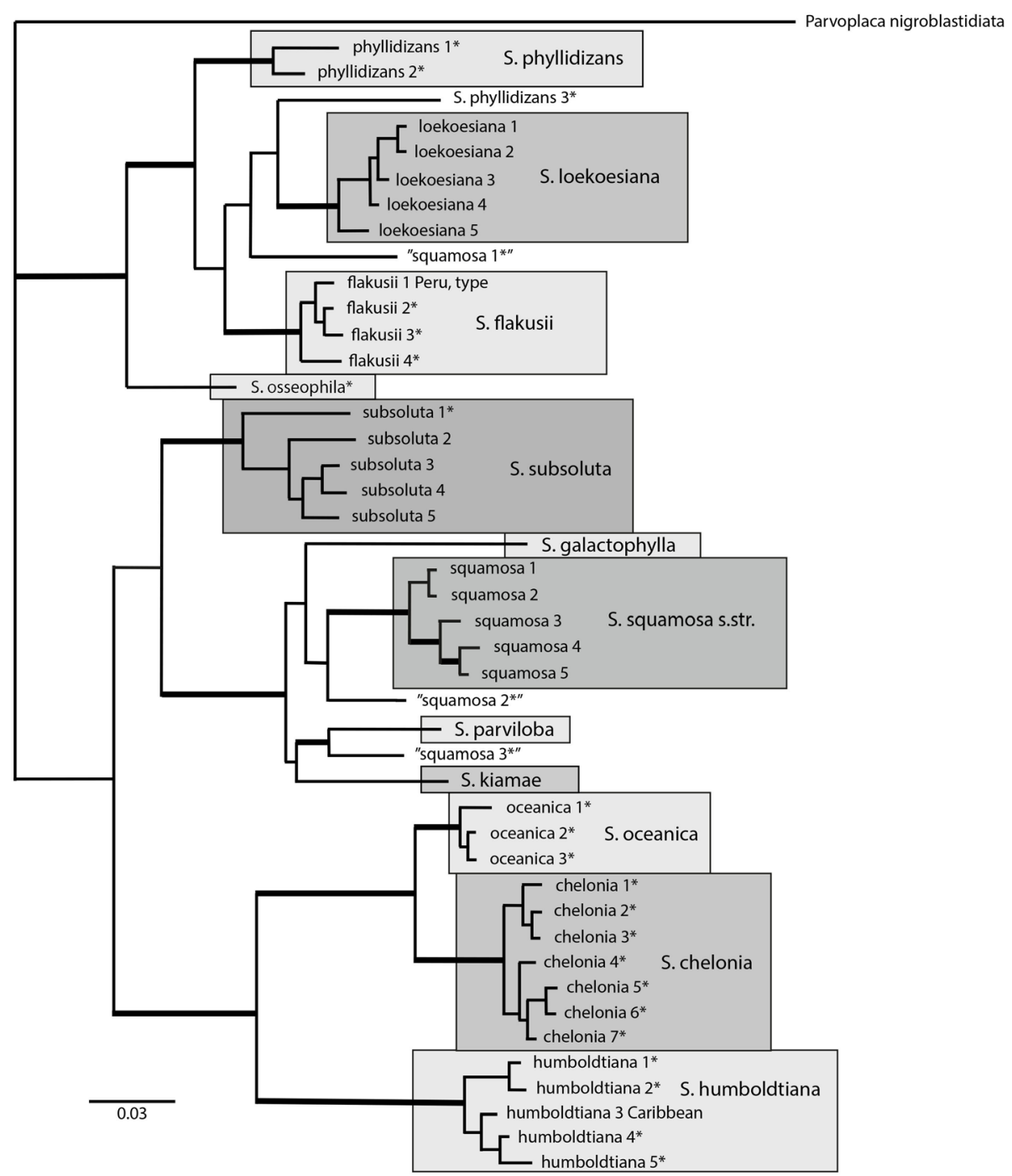

Figure 3. Phylogenetic nrITS tree of selected species in Squamulea (Xanthorioideae), with emphasis on specimens and taxa examined from the Galapagos. Nodes supported by posterior probabilities higher than 0.95 are in bold. Sequences generated from Galapagos material are marked by an asterisk ${ }^{*}$.

The next major subclade distinguishes four new groups with species found in the Galapagos Islands:

The largest well-supported clade is described here as the new genus Oceanoplaca. In the Galapagos, this genus includes three species: $O$. isidiosa, O. chemoisidiosa and O. sideritoides. 'Caloplaca' sideritis is morphologically, biochemically and anatomically inseparable from $O$. sideritoides, but both species do not belong in the same clade (Fig. 2). Even though we were not able to obtain sequence data from other genes, the nrITS data indicates that, despite its similarity, 'C.' sideritis must not be considered to be part of Oceanoplaca. In our analyses, the two species are distinctly separate (Fig. 2). As part of the analysis, Oceanoplaca does, however, include three species from Cape Verde which are not present in the Galapagos: Oceanoplaca caesioisidiata, O. caesiosorediata, and O. catillarioides (Arup \& van den Boom 2011), as well as an additional undescribed species from Argentina.

The sister group to Oceanoplaca consists of a well-supported clade of three species characterized by brown apothecia on a gray thallus. They are described here as Phaeoplaca. The genus includes the previously known P. ochrolechioides from Australia, P. camptidia from North America and Hawaii, and P. tortuca, newly described here from the Galapagos. Although this species cannot be morphologically distinguished from P. camptidia, it is nevertheless phylogenetically distinct, and more closely related to $P$. ochrolechioides than to $P$. camptidia.

The genus Huneckia is delimited in a separate clade (Figs 1-2). This genus was considered monotypic with $H$. pollinii as its only member. Based on our phylogenetic analyses, we include $H$. wrightii from the Galapagos, the USA and northern South America, and H. crocina from South America. Both species also share a common pattern of secondary metabolites with $H$. pollinii.

A fourth clade well-supported by nrITS sequence data is the epiphora-group. In our analysis it is sister to the other three clades, although this position is not significantly supported. This clade is recognized here as the new genus Lacrima; it includes two species that occur in the Galapagos and in the Americas, L. epiphora, L. aphanotripta, and one possible Galapagos endemic, L. galapagoensis. The group further includes $L$. sonorae, a species from the Sonoran Region, not reported from the 
archipelago (Fig. 2). A fifth, currently undescribed species from Argentina also belongs here. It is most closely related to $L$. sonorae.

Further genera in this subclade include Gyalolechia according to the circumscription by Arup et al. (2013a), Jasonhuria (with two species), and Loekoesia. Caloplaca yuchiorum is transferred here to Loekoesia, even though the species is not reported from the Galapagos.

Finally, our phylogenetic overview of Caloplacoideae in Figure 1 includes Blastenia A. Massal., with no representatives in the Galapagos and, on a long branch, Caloplaca diplacia, a taxon for which any close relatives in the subfamily remain unknown. Therefore, we accommodate it in the new, monotypic genus Sucioplaca.

Apart from Leproplaca chrysodeta, the other major subclade of Caloplacoideae does not seem to be represented in the Galapagos. This clade mainly includes genera from the Northern Hemisphere, e.g., Caloplaca s.str. (but none of the Galapagos species treated here as Caloplaca s.1.), Pyrenodesmia, Rufoplaca, Variospora.

The nrITS phylogeny in Figure 2 shows the phylogeny of species mostly from the Galapagos. For taxonomic purposes, other closely related species that do not occur in the Galapagos have also been included. Two genera of Teloschistoideae, Wetmoreana brouardii and 'Caloplaca' cupulifera are positioned at the base of this tree next to the outgroup. Although both are related, a three gene analysis of the subfamily (not presented) did not yield statistical support for including 'Caloplaca' cupulifera within Wetmoreana. Future studies will need to examine their phylogenetic relationship more closely. The rest of the tree consists of clades belonging to the Caloplacoideae. It closely corresponds to our three gene analysis (Fig. 1). All four new genera proposed above re-appear in this tree.

Unfortunately, 'Caloplaca' floridana could not be included in the three-gene phylogeny because we were only able to obtain nrITS sequences from the Galapagos specimens. It is therefore difficult to assess the phylogenetic position of this taxon. The situation is similar for 'Caloplaca' sideritis, for which so far only nrITS sequences are available. Nevertheless, these sequences confirm that the species is genetically distinct from $O$. sideritoides, a newly described species from the Galapagos. In North America, material of ' $C$.' sideritis appears morphologically diverse and additional studies are necessary to assess if this diversity corresponds to one or possibly several different species. The newly described species 'Caloplaca' nigra is undoubtedly distinct and possibly related to 'C.' floridana, but DNA sequence data are so far lacking to resolve its phylogenetic position.

Most species of Huneckia (apart from $H$. wrightii) included in our analyses do not belong to the lichen biota

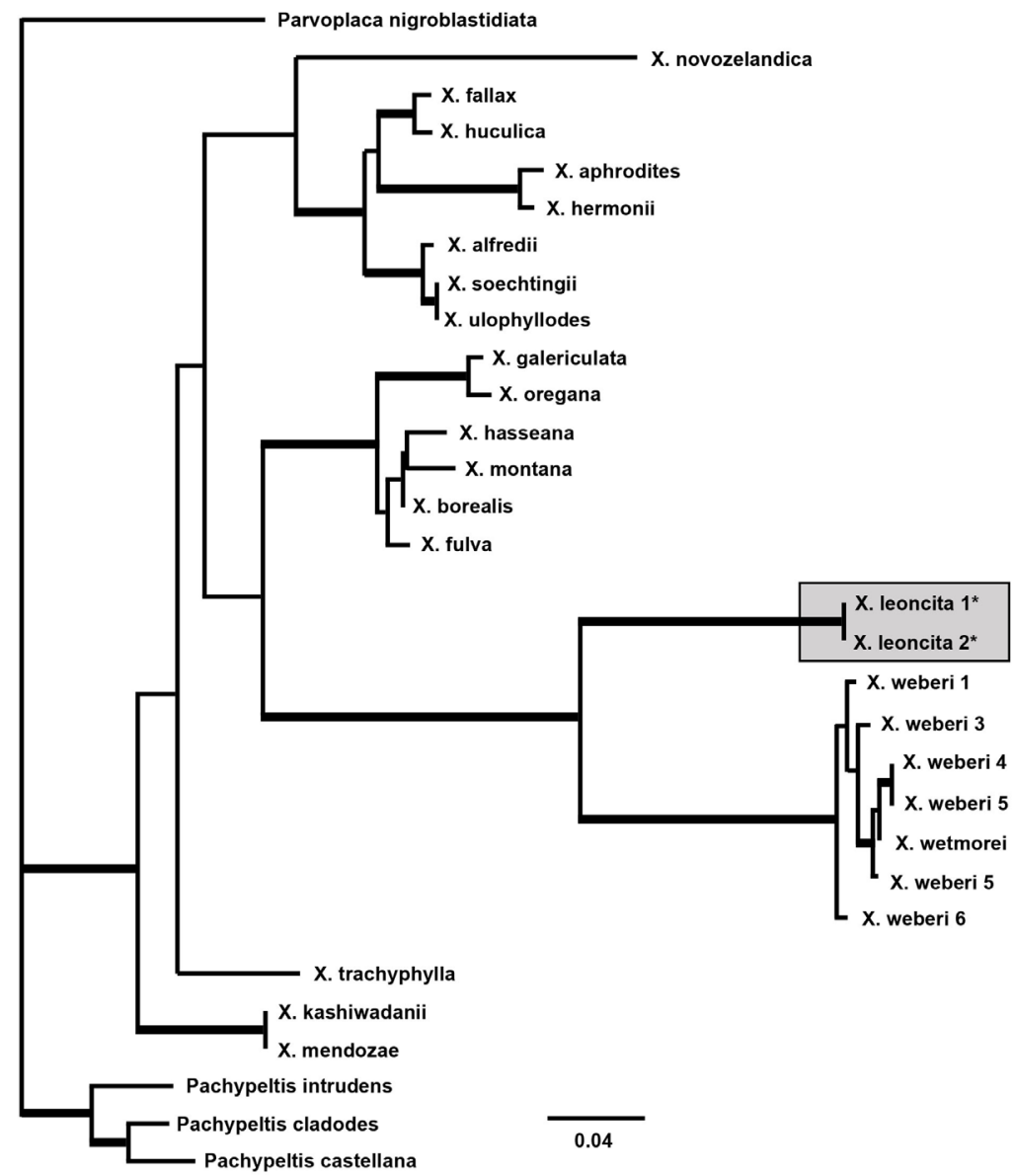

Figure 4. Phylogenetic nrITS tree of the genus Xanthomendoza (Xanthorioideae), showing the newly described X. leoncita forming a clade distinct from the closely related $X$. weberi. Nodes supported by posterior probabilities higher than 0.95 are in bold. Sequences generated from Galapagos material are marked by an asterisk* 
of the archipelago and comprise $H$. pollinii, $H$. rheinigera, and H. crocina. Huneckia rheinigera was described from Australia (Kondratyuk et al. 2007) as distinct from $H$. pollinii, but our analysis does not provide molecular support for the distinction of this taxon. Instead, H. rheinigera appears to be well embedded within the clade of $H$. pollinii. In addition, we were unable to detect any chemical or morphological differences between the two species. Huneckia rheinigera is therefore here reduced into synonymy with $H$. pollinii.

The nrITS phylogeny of Squamulea (sensu Arup et al. 2013a) is presented in Figure 3. The genus is well characterized using classical characters: cortex, exciple and hypothecium of all known species are distinctly paraplectenchymatous and most species grow on siliceous rock. Nevertheless, species delimitation in the genus remains notoriously difficult. A large number of taxa appear to be present in the Galapagos and we were only able to retrieve some of that diversity in our analyses. Any attempt to distinguish the species newly described here by classical characters alone (morphology, anatomy, or chemistry) remains challenging. Most of the diversity within the genus remains poorly resolved. It is therefore very likely that additional undescribed species from the Galapagos will need to be recognized. Our molecular analysis based on nrITS is difficult to translate into any reasonable taxonomy. None of the species, with the possible exception for S. galactophylla (which doesn't occur in the Galapagos) can currently be reliably distinguished using only non-molecular characters. The identification key and the species descriptions of Squamulea in the taxonomic section must therefore be considered very preliminary. The classical morpho-anatomical characters that we present provide guidance, but a broad and thorough analysis is necessary to reliably distinguish species in the genus.

The usually thin, barely squamulose thalli of $S$. subsoluta s.l. can be found in a number of unrelated lineages (Fig. 3). Although S. chelonia is phylogenetically distinct, its thalli can hardly be distinguished from those of $S$. subsoluta (compare Figs 13 \& 16). Both species typically have flattened areoles with barely subsquamulose edges. Thalli of $S$. oceanica are very similar as well, but they often develop from a thin \pm shiny, whitish to blackened hypothallus (in some of the specimens this hypothallus is unfortunately not clearly visible). Thalli of $S$. oceanica grow on calcareous substrates and remain epruinose, while those of $S$. subsoluta and $S$. chelonia are frequently pruinose, but not as coarsely and heavily pruinose as those of $S$. humboldtiana (Fig. 14). Squamulea humboldtiana can also be distinguished by more convex areoles. These resemble those of $S$. osseophila, but growing side by side (on the same piece of bone: Fig. 11A), the thalli of $S$. osseophila remain epruinose, while those of humboldtiana are heavily pruinose.

Specimens with distinctly squamulose thalli (Fig. 16A) are not currently phylogenetically well resolved. Some of the specimens appear to be related to S. squamosa s.str. (as described from the Sonoran Region). Others most likely correspond to currently undescribed species.
For example, one of the specimens we examined seems closely related to $S$. loekoesiana.

The challenge of interpreting classical, morpho-anatomical characters in Squamulea is illustrated by Huriella flakusii, a species originally described from Peru (Wilk 2020). Using molecular data, the species can now also be confirmed from the Galapagos. In the archipelago, it forms a reasonably well supported clade together with the type material from Peru (Fig. 3). The morphology of Galapagos specimens is, however, quite different from the holotype illustrated in Wilk (2020). Galapagos specimens are pale orange (vs. deep orange) and they are more conspicuously squamulose with thalli composed of tiny, closely aggregated rosettes (Fig. 13A-B). The habitat of the species in Peru, at an elevation of $\sim 3500 \mathrm{~m}$, also differs from the specimens collected in the Galapagos, even though the Galapagos specimens were at least collected also at a relatively high altitude on top of Volcán Alcedo above $1000 \mathrm{~m}$.

Another confusing example is Squamulea phyllidizans. This species is characterized morphologically by distinctly squamulose, almost subfoliose, coarsely blastidiate-sorediate thalli. At least in the Galapagos, the taxon is thus easily distinguished from all other squamulose morphotypes of Squamulea. Galapagos specimens, nevertheless, do not form a distinct clade well separated from other specimens of Squamulea. Instead, this conspicuous morphology seems to have evolved at least twice.

Ironically, some Galapagos specimens of S. phyllidizans form a sister group to Huriella, a genus described to accommodate the single species H. loekoesiana (Fig. 3). According to the authors, this genus differs from Squamulea by its more crustose, non-squamulose thalli, smaller apothecia and narrower spores (Kondratyuk et al. 2017). Our analysis suggests however that the distinctly squamulose $S$. phyllidizans would either have to be included within 'Huriella', or a new genus would be necessary to accommodate its different thallus growth type. But even though the clade with the type species $H$. loekoesiana is well supported (Fig. 3), this species is also known to form squamulose thalli with larger apothecia and with spores that are generally similar in width to most other Squamulea species (cf. Wetmore 2003). None of the characters previously considered characteristic for 'Huriella' can therefore be used to support this genus. Instead, the same clade includes several specimens with typical Squamulea morphology. In the phylogeny presented here, for example, the clade includes $S$. osseophila, a species not distinctly squamulose, a sister group to both 'Huriella' and $S$. phyllidizans.

In conclusion, a much broader analysis with more genes is therefore clearly warranted before a genus 'Huriella' might be accepted. From a morphological and anatomical point of view, the name is presently not informative. It instead obscures phylogenetic relationships as they are currently known. Consequently, we here synonymize Huriella with Squamulea.

Finally, our nrITS phylogenetic tree of Xanthomendoza (Fig. 4) justifies the recognition of the new species $X$. leoncita. This species is closely related to $X$. weberi, but 
genetically distinct, and it is most likely endemic to the Galapagos. Sequences of $X$. kashiwadanii and X. soechtingii, both absent from the Galapagos, were included in our analysis. The two are separate from Xanthomendoza leoncita, but $X$. kashiwadanii is genetically identical with $X$. mendo$z a e$, and $X$. soechtingii with $X$. ulophyllodes. Therefore, we place $X$. kashiwadanii into synonymy with $X$. mendozae, and $X$. soechtingii into synonymy of $X$. ulophyllodes.

\section{Taxonomy}

Caloplacoideae Arup, Søchting \& Frödén, subfam. nov.

MycoBank MB 837368

Type genus: Caloplaca Th. Fr.

Taxonomic note: The name for this subfamily was originally proposed by Gaya et al. (2012) and adopted by Arup et al. (2013a). Both published the subfamily without a diagnosis, which is here provided to formally validate the name.

Diagnosis: The subfamily represents a major, well-supported clade in the molecular phylogeny of Teloschistaceae. It differs from Xanthorioideae in the following nrLSU DNA sequence pattern: usually having an A (rarely $\mathrm{G}, \mathrm{C}$ or lacking) versus an $\mathrm{G}$ (rarely A or C) in the sequence AGGTG(alt. A)GGAACCCNAGGGCGCACC(alt. T)ATCGA; and in the following mrSSU DNA sequence pattern: usually having an A (rarely a T) versus usually a $\mathrm{G}$ (rarely an $\mathrm{A}$ ) in the sequence TA(alt. T) TGCCTTACAAAGAGATGCT(alt. A or C)AAATT, and from Teloschistoideae in the mrSSU sequence pattern usually having a A (T) versus usually an $\mathrm{T}$ in the sequence TTCTGGGTAGGCTTTTGATAATGACA and in usually having an A versus a $\mathrm{G}$ in the sequences TGTGATAAT(alt. $\mathrm{C}$ or G)AGAGATCAAGACAAG. The subfamily Caloplacoideae includes widely distributed species with a very diverse secondary chemistry. Most species accommodated in this family are crustose, i.e., tightly adhered to their substrate without developing a distinct lower surface, but some species are fruticose.

Caloplaca Th. Fr., Lich. arct. (Uppsala): 118. 1860.

MycoBank MB 749

Taxonomic note: The species below are included here within Caloplaca s.l. Our phylogenetic analyses failed to accommodate these taxa in any well-defined clade. Caloplaca floridana is part of the Caloplacoideae, for C. nigra DNA extractions were unsuccessful. 'Caloplaca' cupulifera is clearly a member of the Teloschistoideae and treated there.

Caloplaca floridana (Tuck.) S.C. Tucker, Bryologist 82(2): 132. 1979.

(Fig. 5C-E)

MycoBank MB 341655

Basionym: Lecanora floridana Tuck., Proc. Amer. Acad. Arts \& Sci. 5: 402.1862 [1860]; MycoBank MB 388267.

Description. Thallus continuous to indistinctly rimose, small patches up to $2.5 \mathrm{~cm}$ in diam., effuse, but typically delimited by a radiating, \pm fibrous black prothallus; surface deep blackish gray to olive gray, smooth, not shiny, epruinose, lacking vegetative propagules. Apothecia numerous, dispersed, sessile, up to $0.6 \mathrm{~mm}$ in diam., biatorine-lecideine (not or only very weakly carbonized), thalline margin absent, but when emerging occasionally covered in part by a thin thallus residue ('thalline veil'); proper margin thin, $\sim 60 \mu \mathrm{m}$ thick, prominent, regularly circular, black, concolorous with the disc, epruinose; disc flat, becoming slightly convex with age, black, epruinose; epihymenium bluish black, pigmentation diffuse, $\mathrm{C}+$ wine red, $\mathrm{K}+$ violet, pigment granules absent, \pm contiguous with the outer exciple; hymenium hyaline, not inspersed; proper exciple differentiated into an inner hyaline part, lacking crystals, and an outer part with a diffuse bluish black pigment, $\mathrm{C}+$ wine red, $\mathrm{K}+$ violet; subhymenium and hypothecium not differentiated, hyaline, not inspersed; asci clavate, Teloschistes-type; ascospores 8/ascus, polaribilocular, spores narrowly ellipsoid to weakly citriform (moderately tapering), $(10.7-) 12.1-14.9(-16.5) \times(5.1-) 5.7-7.0(-8.5) \mu \mathrm{m}$, with a thick, (3.9-)4.8-6.8(-8.6) $\mu \mathrm{m}$ wide septum $(\mathrm{n}=50)$. Pycnidia unknown.

Chemistry. Thallus and apothecia $\mathrm{P}-, \mathrm{K}-, \mathrm{C}-, \mathrm{KC}-$, UV-(dull); no secondary metabolites detected.

Ecology and distribution. Presumably widely distributed in dry habitats of the Neotropics. Tuckerman (1862) originally described the species from Florida (USA), Tucker (1979) subsequently reported it from Lousiana (USA), Wetmore (2007a) from Sinaloa (Mexico), suggesting it may be restricted to North America, even though Weber (1986) had already reported it from the Galapagos. There, the species occurs from the coastal throughout the dry into the lower transition zone. In Galapagos, the species has so far only been found on Bursera graveolens, typically on sunny, wind- and rain-exposed trunks, branches and twigs.

Notes. The only other Teloschistaceae species with blackened apothecia in the Galapagos is the saxicolous Caloplaca nigra (differences discussed there). Caloplaca floridana is represented here by three ITS sequences that are very uniform and well separated from all other species.

Specimens examined from Ecuador, Galápagos. ISABELA, VOLCÁN ALCEDO: $\sim 100 \mathrm{~m}$ inland from the shore a little $\mathrm{N}$ of Islote Cowley, $0^{\circ} 23^{\prime} 43^{\prime \prime} \mathrm{S}, 90^{\circ} 59^{\prime} 54^{\prime \prime} \mathrm{W}, 25 \mathrm{~m}$ alt., coastal zone, plane with small pebbles of lava tuff, mostly open, occasional groups of small Bursera graveolens trees, shrubs of Scalesia affinis, Cordia lutea, Scutia spicata var. pauciflora, on bark, 11-Mar-2006, Aptroot, A. 64727 (CDS 31302); highest cinder cone along the trail going up the E-slope, $0^{\circ} 23^{\prime} 37^{\prime \prime} \mathrm{S}, 91^{\circ} 1^{\prime} 31^{\prime \prime} \mathrm{W}$, $250 \mathrm{~m}$ alt., dry zone, basalt outcrops, at the bottom scattered Bursera graveolens trees and shrubs of Castela galapageia, on bark, 10-Mar-2006, Aptroot, A. 65019 (CDS 31601); along the trail going up the E-slope, $0^{\circ} 23^{\prime} 51^{\prime \prime} \mathrm{S}, 91^{\circ} 2^{\prime} 7^{\prime \prime} \mathrm{W}, 316 \mathrm{~m}$ alt., dry zone, very open Bursera graveolens stand with scattered Opuntia insularis, and dense scrub of Macraea laricifolia and Waltheria ovata, on bark, 10-Mar-2006, Bungartz, F. 4461 (CDS 28547); at the NW-side of the trail, $0^{\circ} 24^{\prime} 5^{\prime \prime} \mathrm{S}, 91^{\circ} 2^{\prime} 36^{\prime \prime} \mathrm{W}$, $420 \mathrm{~m}$ alt., dry zone, open Bursera graveolens stand with an occasional Pisonia floribunda and Zanthoxylum fagara and shrubs of Macraea laricifolia and Waltheria ovata, on bark, 09-Mar-2006, Bungartz, F. 4373 (CDS 28457); cinder cones along the trail going up the E-slope, $0^{\circ} 23^{\prime} 40^{\prime \prime} \mathrm{S}, 91^{\circ} 1^{\prime} 18^{\prime \prime} \mathrm{W}$, $190 \mathrm{~m}$ alt., dry zone, basalt outcrops, at the bottom scattered 
Bursera graveolens trees and shrubs of Castela galapageia, on bark, 10-Mar-2006, Bungartz, F. 4482 (CDS 28568). VOLCÁN DARWIN: southwestern slope, above Tagus Cove, $0^{\circ} 13^{\prime} 59^{\prime \prime} \mathrm{S}$, $91^{\circ} 20^{\prime} 8^{\prime \prime} \mathrm{W}, 597 \mathrm{~m}$ alt., dry zone, open Bursera graveolens forest with Croton scouleri and Macraea laricifolia shrubs, few Chiococca alba and Scalesia microcephala, among lava boulders and outcrops, on bark, 16-Nov-2007, Bungartz, F. 7841 (CDS 38350); Tagus Cove at the W-coast of the island, along tourist trail above the lagoon Beagle I, $0^{\circ} 15^{\prime} 17^{\prime \prime} \mathrm{S}, 91^{\circ} 22^{\prime} 10^{\prime \prime} \mathrm{W}, 63 \mathrm{~m}$ alt., dry zone, open Bursera graveolens forest on ridge with Scutia spicata, Castela galapageia and Waltheria ovata, on bark, 18-Nov-2007, Bungartz, F. 7990 (CDS 38500); inland from Tagus Cove at the W-coast of the island, $0^{\circ} 15^{\prime} 8.693^{\prime \prime} \mathrm{S}$, $91^{\circ} 22^{\prime} 23^{\prime \prime} \mathrm{W}, 77 \mathrm{~m}$ alt., dry zone, very open Bursera forest on W-exposed slope with Scalesia affinis, Macraea laricifolia, Cordia revoluta, and Waltheria ovata among lava flows of weathered AA-lava, on bark, 17-Nov-2007, Bungartz, F. 7977 (CDS 38487); at the W-coast between Tagus Cove and Caleta Negra, $\sim 1 \mathrm{~km}$ inland from the coast, $0^{\circ} 14^{\prime} 50^{\prime \prime} \mathrm{S}, 91^{\circ} 22^{\prime} 43^{\prime \prime} \mathrm{W}, 55 \mathrm{~m}$ alt., dry zone, open Bursera graveolens forest on NW-exposed slope with Scutia spicata, Castela galapageia and Waltheria ovata, on bark, 17-Nov-2007, Bungartz, F. 7935 (CDS 38445). SAN CRISTÓBAL: near Rosa Blanca, inland from the SE-coast of the island, $0^{\circ} 49^{\prime} 9^{\prime \prime} \mathrm{S}, 89^{\circ} 21^{\prime} 48^{\prime \prime} \mathrm{W}, 12 \mathrm{~m}$ alt., dry zone, open Bursera graveolens woodland with Mentzelia aspera and Scalesia incensa shrubs on lava flow, on bark, 23-Apr-2007, Bungartz, F. 6408 (CDS 34623); crest of Cerro Tortuga, $\sim 4 \mathrm{~km}$ inland from the NW-coast, $0^{\circ} 44^{\prime} 54^{\prime \prime} \mathrm{S}, 89^{\circ} 23^{\prime} 32^{\prime \prime} \mathrm{W}, 116 \mathrm{~m}$ alt., dry zone, open Piscidia carthagenensis woodland with few Bursera graveolens and dense understory of Croton scouleri, Cordia lutea, and Mentzelia aspera on rocky SE-exposed slope of hill, on bark, 25-Apr-2007, Bungartz, F. 6521 (CDS 34739); Cerro Mundo, rock cliffs on the S side close to the summit, $0^{\circ} 53^{\prime} 32^{\prime \prime} \mathrm{S}$, $89^{\circ} 34^{\prime} 40^{\prime \prime} \mathrm{W}, 253 \mathrm{~m}$ alt., transition zone, with Bursera graveolens, Croton scouleri, Piscidia carthagenensis, Zanthoxylum fagara and a few Scalesia pedunculata, slope $45^{\circ}$ ESE, on rock, 25-Aug-2008, Truong, C. 1542 (CDS 39853). SANTA FÉ: lava flow at the N-coast of the island, $0^{\circ} 48^{\prime} 6^{\prime \prime} \mathrm{S}, 90^{\circ} 2^{\prime} 39^{\prime \prime} \mathrm{W}$, $42 \mathrm{~m}$ alt., dry zone, S-exposed side of lava flow with scarce vegetation (shrubs of Croton scouleri, Cordia lutea, few Bursera graveolens trees, and Opuntia echios var. barringtonensis), on bark, 25-Oct-2007, Jonitz, H. 9 (CDS 44609); Bungartz, F. 7265 (CDS 37749); Ertz, D. 11662 (CDS 36988); on top of lava flow at the N-coast of the island, $0^{\circ} 48^{\prime} 12^{\prime \prime} \mathrm{S}, 90^{\circ} 2^{\prime} 34^{\prime \prime} \mathrm{W}, 13 \mathrm{~m}$ alt., coastal zone, open scrubland of partly dead shrubs (Croton scouleri, Cordia lutea), few shrubby Bursera graveolens, and Opuntia echios var. barringtonensis among lava rocks, on bark, 25-Oct-2007, Bungartz, F. 7217 (CDS 37701). SANTA CRUZ: along the trail from Puerto Ayora to Bahía Tortuga, $0^{\circ} 44^{\prime} 48^{\prime \prime} \mathrm{S}, 90^{\circ} 19^{\prime} 14^{\prime \prime} \mathrm{W}, 28 \mathrm{~m}$ alt., dry zone, decidous forest in dry zone; with Bursera graveolens, Acacia rorudiana, and Opuntia echios; over basalt, on bark, 05-Jan-2006, Bungartz, F. 3346 (CDS 27013); Puerto Ayora, cliff N of the town, $0^{\circ} 43^{\prime} 59^{\prime \prime} \mathrm{S}$, $90^{\circ} 18^{\prime} 45^{\prime \prime} \mathrm{W}, 20 \mathrm{~m}$ alt., dry zone, on bark, 11-Feb-2006, Aptroot, A. 63739 (CDS 30297); on bark, Hill, T. s.n. (FH-TUCK 197146). FLOREANA: along trail going to Post Office Bay off the dirt road between highlands and Puerto Velasco Ibarra, at Laguna Seca, $1^{\circ} 15^{\prime} 30^{\prime \prime} \mathrm{S}, 90^{\circ} 26^{\prime} 26^{\prime \prime} \mathrm{W}, 206 \mathrm{~m}$ alt., dry zone, very open Bursera graveolens forest over SE-exposed lava flow with Prosopis juliflora, on bark, 14-Jan-2011, Bungartz, F. 9533 (CDS 46816); lava flow behind beach ('White Beach') at SE side of Punta Cormorán, $\sim 150 \mathrm{~m}$ inland, $1^{\circ} 13^{\prime} 45^{\prime \prime} \mathrm{S}, 90^{\circ} 25^{\prime} 28^{\prime \prime} \mathrm{W}$, $6 \mathrm{~m}$ alt., coastal zone, open Bursera graveolens forest with some Scutia spicata, Acacia rorudiana and Waltheria ovata and Mentzelia aspera in the understory, on bark, 19-Jan-2011, Bungartz, F. 9931 (CDS 47300), 9901 (CDS 47239). SANTI-
AGO: $\sim 5 \mathrm{~km}$ inland from the E-coast, \pm at the same latitude as Bahía Sullivan, $0^{\circ} 16^{\prime} 52^{\prime \prime} \mathrm{S}, 90^{\circ} 37^{\prime} 17^{\prime \prime} \mathrm{W}, 175 \mathrm{~m}$ alt., dry zone, rubble of older lava with very scarce vegetation of few Bursera graveolens trees, Macraea laricifolia, and Mentzelia aspera, on bark, 16-Jul-2006, Bungartz, F. 5040 (CDS 29253); 500 m $\mathrm{S}$ of Bucanero, near the canyon at the northeastern foothills of Cerro Cowan (near permanent monitoring plot \# 4 'Encañada'), $0^{\circ} 10^{\prime} 21^{\prime \prime} \mathrm{S}, 90^{\circ} 49^{\prime} 30^{\prime \prime} \mathrm{W}, 70 \mathrm{~m}$ alt., dry zone, open woodland with Castela galapageia, Cordia lutea, Vallesia glabra, Opuntia galapageia, on bark, 21-Mar-2006, Bungartz, F. 4540 (CDS 28626); $0.4 \mathrm{~km} \mathrm{~S}$ of James Bay, $0^{\circ} 14^{\prime} 30^{\prime \prime} \mathrm{S}, 90^{\circ} 51^{\prime} 30^{\prime \prime} \mathrm{W}, 7 \mathrm{~m}$ alt., dry zone, open Bursera forest on consolidated ash, on bark, 25-Apr-1971, Pike, L.H. 2547 (L-56167, COLO 263244), 2547 (OSC 53524), 2530 (OSC 53522); $0^{\circ} 13^{\prime} 50^{\prime \prime} \mathrm{S}, 90^{\circ} 50^{\prime} 50^{\prime \prime} \mathrm{W}$, $15 \mathrm{~m}$ alt., dry zone, open Bursera forest on S-facing slope of red cinder cone next to sea and nearly surrounded by recent lava flow, on bark, 28-Apr-1971, Pike, L.H. 2660 (OSC 53523). RÁBIDA: al lado este de la isla, $0^{\circ} 23^{\prime} 58^{\prime \prime} \mathrm{S}, 90^{\circ} 42^{\prime} 36^{\prime \prime} \mathrm{W}, 27 \mathrm{~m}$ alt., zona costera, dominante Bursera graveolens, sobre corteza, 21-Jul-2006, Nugra, F. 90 (CDS 32744); NW-side of Rábida, $0^{\circ} 23^{\prime} 59^{\prime \prime} \mathrm{S}, 90^{\circ} 42^{\prime} 35^{\prime \prime} \mathrm{W}, 27 \mathrm{~m}$ alt., dry zone, on top of coastal lava cliff above the beach; N-exposed slope with lava boulders, rocks and young Bursera graveolens trees (max. $3 \mathrm{~m}$ in height), on bark, 21-Jul-2006, Bungartz, F. 5349 (CDS 29565). PINTA: along the trail up to the summit, $\sim 1 \mathrm{~km}$ inland from the S-coast, $0^{\circ} 33^{\prime} 31^{\prime \prime} \mathrm{N}, 90^{\circ} 44^{\prime} 38^{\prime \prime} \mathrm{W}, 107 \mathrm{~m}$ alt., dry zone, open vegetation of Bursera graveolens, Croton scouleri, Castela galapageia, and Opuntia galapageia among lava blocks, on bark, 25-Feb-2007, Bungartz, F. 5675 (CDS 33310).

\section{Caloplaca nigra Bungartz \& Søchting, sp. nov.}

(Fig. 5F-H)

\section{MycoBank MB 836936}

Diagnosis: A saxicolous species with blackened, cryptolecanorine to \pm aspicilioid apothecia on a brownish olive, distinctly areolate thallus; possibly related to the corticolous C. floridana, which also lacks secondary metabolites, but has sessile, black, biatorine-lecideine apothecia on a dark gray, rimose thallus.

Type: Ecuador, Galápagos: San Cristóbal, hills S of Punta Pit at the NE-coast of the island, $0^{\circ} 43^{\prime} 16^{\prime \prime} \mathrm{S}, 89^{\circ} 14^{\prime} 40^{\prime \prime} \mathrm{W}, 63 \mathrm{~m}$ alt., coastal zone, SSE-exposed ridge of basalt cliff, on rock, 21-Apr-2007, Bungartz, F. 6170 A (CDS 34382-holotype).

Description. Thallus distinctly areolate, not delimited by a prothallus, effuse, but individual areoles in part occasionally eroded, especially around their margin, then as if delimited by a whitish border; surface dark brownish olive, smooth, \pm shiny, epruinose, lacking vegetative propagules. Apothecia sparse to abundant, dispersed, \pm aspicilioid, i.e., initially immersed and \pm cryptolecanorine, their margin barely distinct from the thallus, eventually becoming adnate and then lecanorine; thalline margin thick, circular, dark brownish olive, concolorous with the thallus, epruinose; proper margin absent; disc plane to very slightly convex, black, epruinose, $\mathrm{C}-$, $\mathrm{K}$-; epihymenium brownish olive, pigmentation diffuse, $\mathrm{C}-, \mathrm{K}-, \pm$ contiguous with the outer exciple; hymenium hyaline, not inspersed; proper exciple absent (completely reduced); thalline exciple pronounced, differentiated into a central part abundantly filled with trebouxioid photobionts, lacking crystals, followed by a hyaline layer that becomes increasingly pigmented towards the outside, pigmentation brownish olive, diffuse, $\mathrm{C}-$, $\mathrm{K}-$; subhymenium and 
hypothecium not differentiated, hyaline, not inspersed; asci broadly clavate, Teloschistes-type; ascospores 8/ascus, polaribilocular, ellipsoid to broadly ellipsoid, $(9.0-) 10.0-11.3(-12.5) \times(4.5-) 5.8-7.8(-11.0) \mu \mathrm{m}$, with a moderately broadened, (2.0-)3.0-4.1(-4.5) $\mu \mathrm{m}$ wide septum $(n=42)$. Pycnidia unknown.

Chemistry. Thallus and apothecia $\mathrm{P}-, \mathrm{K}-, \mathrm{C}-, \mathrm{KC}-$, UV- (dull); no secondary metabolites detected.

Etymology. Named for its black apothecial discs.

Ecology and distribution. Known only from the Galapagos where it grows from the coast into the lower transition zone, on sunny, wind- and rain-exposed rock.

Notes. DNA extraction of the material was unfortunately not successful. Nevertheless, the species is described here as new, because of its unique characteristics. The only other Caloplaca in Galapagos with black apothecia is the corticolous ' $C$.' floridana. It does not grow on rock, forms a rimose, dark gray thallus that is distinctly delimited by a black, fibrous prothallus (Fig. 5C). Though apothecia of ' $C$.' floridana occasionally emerge with fragments of necrotic thalline material attached, they are not distinctly aspicilioid, but soon become sessile and distinctly lecideine; internally weakly carbonized by a bluish black pigment ( $\mathrm{C}+$ wine red, $\mathrm{K}+$ violet). 'Caloplaca' nigra has apothecia which initially remain immersed, of \pm aspiciliod appearance, but eventually emerge with a persistent, distinctly lecanorine margin (Fig. 5G); the disc is blackened by a different, black pigment that does not react $(\mathrm{C}-$-, $\mathrm{K}-$ ). The thallus of $C$. nigra is brownish olive, distinctly areolate and not delimited by a prothallus (Fig. 5F).

Specimens examined from Ecuador, Galápagos. FERNANDINA: $335 \mathrm{~m}$ alt., transition zone, 15-Feb-1964, Cavagnaro, D. 318 (L-35612, COLO 245815). ISABELA, VOLCÁN ALCEDO: highest cinder cone along the trail going up the E-slope, $0^{\circ} 23^{\prime} 37^{\prime \prime} \mathrm{S}, 91^{\circ} 1^{\prime} 31^{\prime \prime} \mathrm{W}, 250 \mathrm{~m}$ alt., dry zone, basalt outcrops, at the bottom scattered Bursera graveolens trees and shrubs of Castela galapageia, on rock, 10-Mar-2006, Aptroot, A. 65023 (CDS 31605). SAN CRISTÓBAL: inland from Punta Pit at the NE-coast of the island, $0^{\circ} 43^{\prime} 6^{\prime \prime} \mathrm{S}, 89^{\circ} 14^{\prime} 36^{\prime \prime} \mathrm{W}, 20 \mathrm{~m}$ alt., dry zone, NNW-exposed slope of old lava flow with scarce vegetation, on rock, 20-Apr-2007, Bungartz, F. 6093 (CDS 33772).

Huneckia S.Y. Kondr., Elix, Kärnefelt, A. Thell \& Hur, in Kondratyuk, Jeong, Yu, Kärnefelt, Thell, Elix, Kim, Kondratyuk \& Hur, Acta bot. hung. 56(1-2): 102. 2014.

MycoBank MB 807180

Huneckia wrightii (Willey) Arup, Søchting \& Bungartz, comb. nov.

(Figs 1-2, 6A-D)

MycoBank MB 836937

Basionym: Placodium ferrugineum var. wrightii Tuck., A synopsis of the North American lichens 1: 178. 1882. MycoBank MB 245802.

Description. Thallus either as thin and poorly developed, isolated to irregularly associated verruculose areoles on a smooth blackish gray hypothallus, or irregularly thickened and at least in part rimose-areolate to distinctly verruculose areolate, typically \pm discontinuous, with discrete, contiguous thallus areas interrupted by thin, poorly developed parts and a blackened hypothallus in between, which also delimits the effuse periphery as a compact, blackened, \pm carbonaceous prothallus; surface pale creamy white to grayish, smooth to \pm roughened, dull to \pm shiny (in parts \pm 'waxy'), epruinose, sparsely to densely isidiate; isidia granular to cylindrical and sparsely to irregularly branched, rarely \pm coralloid, pale creamy white, darker gray to bluish green at their tips, $\sim 0.06-0.08 \mathrm{~mm}$ in diam., the whole thallus eventually appearing pale greenish gray as a result of the dense isidia (fertile specimens often with a thicker, better developed thallus and less densely isidiate; poorly developed, sterile specimens typically with few, pale clusters of isidia on a bluish black hypothallus). Apothecia, frequently absent or sparse to sometimes numerous, dispersed, up to $1.2 \mathrm{~mm}$ in diam., 'zeorine' to almost biatorine; thalline margin soon excluded by being pushed below, beige to whitish, sometimes granular to isidioid (in the herbarium often blackened with age); proper margin almost level with disc, persistent, $\sim 100 \mu \mathrm{m}$ thick, regularly circular to slightly flexuose; brownish to rust-red orange, epruinose, $\mathrm{C}-, \mathrm{K}+$ purple; disc flat, deep brownish to rust-red orange, epruinose, $\mathrm{C}-, \mathrm{K}+$ purple; epihymenium deep orange-brown, strongly colored by deep orange pigment granules, $\mathrm{C}-( \pm$ intensifying winered), $\mathrm{K}+$ violet, pigmentation contiguous with upper part of the outer exciple; hymenium hyaline, not inspersed; proper exciple differentiated into an inner, hyaline part, lacking crystals, and an outer pigmented part, strongly colored by deep orange pigment granules, $\mathrm{C}-( \pm$ intensifying wine-red), $\mathrm{K}+$ violet; thalline exciple initially developed along the outside, soon pushed below, densely filled with trebouxioid photobionts and small crystals that dissolve in $\mathrm{K}$, the outside not distinctly pigmented, $\mathrm{C}-$, $\mathrm{K}$-; subhymenium grayish, hypothecium hyaline, both not inspersed; asci clavate, Teloschistes-type; ascospores 8/ ascus, polaribilocular, spores narrowly ellipsoid to weakly citriform (moderately tapering), (10.0-)11.9-14.7(-16.0) $\times(6.1-) 7.4-9.3(-10.3) \mu \mathrm{m}$, with a thick, (2.9-)3.65.3(-6.0) $\mu \mathrm{m}$ wide septum $(\mathrm{n}=35)$. Pycnidia unknown.

Chemistry. Thallus $\mathrm{P}-, \mathrm{K}-, \mathrm{C}+$ orange, $\mathrm{KC}+$ orange, $\mathrm{UV}+$ deep to bright yellow orange, apothecia $\mathrm{P}-, \mathrm{K}+$ purple, $\mathrm{C}-, \mathrm{KC} \pm$ purplish (fading), $\mathrm{UV}+$ deep to bright yellowish orange; the thallus only contains lichexanthone, apothecia additionally also chrysophanal and rhein. Wetmore (2007) reports parietin and emodin; neither of these compounds were found in the Galapagos specimens.

Ecology and distribution. According to Wetmore (2007a), occurring from southwestern USA through Mexico into northern South America: New to Ecuador and the Galapagos, where the species is common throughout the dry and lower transition zone, typically in sunny, wind- and rain-exposed habitats, most frequently on Bursera graveolens, occasionally on Cordia lutea, Prosopis juliflora, and few other trees characteristic of dry, open woodland. 

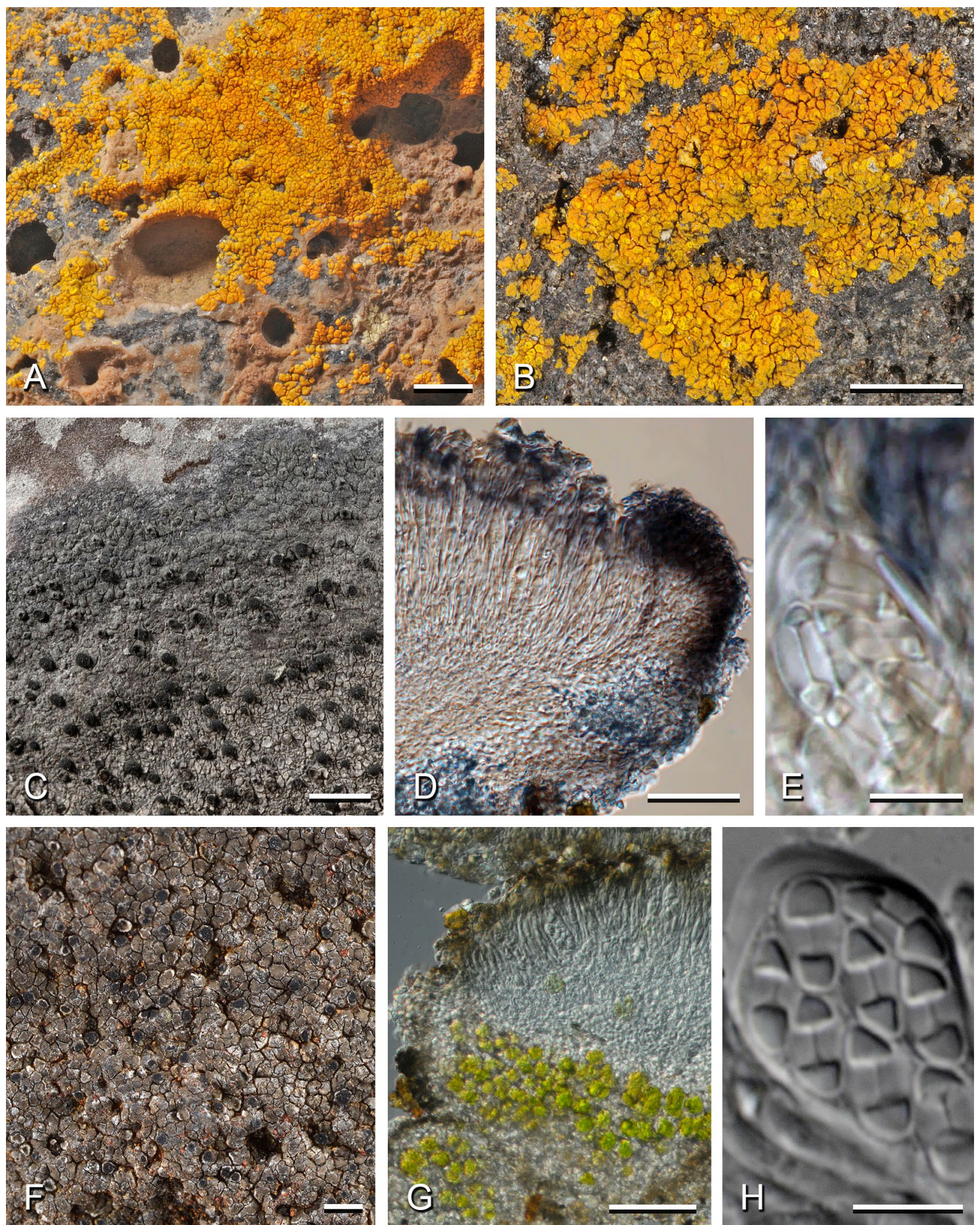

Figure 5. Species of Caloplaca s.l. A-B - Caloplaca cupulifera. A - orange, areolate subsquamulose thallus, with sparse, \pm crateriform, bright yellow soralia (Bungartz 5407, CDS 29623); B - orange, areolate-subsquamulose thallus, with abundant, bright yellow, crateriform soralia, extruding granular soredia (Aptroot, A. 30276, CDS 63720). C-E - Caloplaca floridana; C - dark gray, rimose thallus, not delimited by a prothallus, with black, lecideine apothecia (Bungartz, F. 6408, CDS 34623); D - apothecial section: lecideine, outer exciple and epihymenium moderately carbonized by bluish black pigment, inner exciple and hypothecium hyaline [DIC, in water] (Aptroot, A. 64727, CDS 31302); E - ascus with oblong ascospores, septum broad [DIC, in water] (Bungartz, F. 7265, CDS 37749). F-H - Caloplaca nigra (Bungartz, F. 6170 A, CDS 34382holotype); F - areolate deep olive-brown thallus with blackened, \pm aspicilioid to adnate lecanorine apothecia; $\mathrm{G}$ - apothecial section: lecanorine, outer thalline exciple and epihymenium with olive-black pigment, inner, lower exciple with trebouxioid green algae [DIC, in water]; $\mathrm{H}-$ broadly clavate ascus with oblong to ellipsoid spores, septum moderately broad [DIC, in water]. Scales: A-C, F = 2 mm; D, G = $100 \mu \mathrm{m} ; \mathrm{E}, \mathrm{H}=10 \mu \mathrm{m}$. 
Notes. Huneckia wrightii is a well-delimited species, easily recognized if fertile. Specimens lacking apothecia could be confused with Pertusaria xanthoisidiata, but that species has a much thicker, yellowish green thallus with a more contiguous smooth surface and much coarser, stout isidia ( $\sim 0.1-0.16 \mathrm{~mm}$ in diam.), that frequently erode at their tip. The isidia in C. writhii do not erode apically, but break off entirely. Its thalli fluoresce UV+ deep to bright yellow orange due to lichexanthone, whereas those of $P$. xanthoisidiata are $\mathrm{UV} \pm$ dull orange (for comparison see also Bungartz et al. 2015).

If sterile, specimens of Megalaria bengalensis could be mistaken for $H$. wrightii. Thalli of $M$. bengalensis are greenish, contain no xanthones and, therefore, do not fluoresce (UV-), their isidia are much finer (typically less than $0.07 \mathrm{~mm}$ in diam.). When fertile, the specimens with their black, distinctly lecideine apothecia can of course not be confused.

Specimens examined from Ecuador, Galápagos. ISABELA, VOLCÁN ALCEDO: in the crater near fumaroles, $0^{\circ} 27^{\prime} 1^{\prime \prime} \mathrm{S}$, $91^{\circ} 7^{\prime} 19^{\prime \prime} \mathrm{W}, 780 \mathrm{~m}$ alt., transition zone, mostly Bursera graveolens and dense scrub on uneven lava, on bark, 07-Mar-2006, Aptroot, A. 64787 (CDS 31362); along the trail going up the E-slope, basalt rubble field to the SE-side of the trail and the barranco, $0^{\circ} 24^{\prime} 3^{\prime \prime} \mathrm{S}, 91^{\circ} 2^{\prime} 35^{\prime \prime} \mathrm{W}, 434 \mathrm{~m}$ alt., dry zone, basalt rubble field with scattered vegetation (Bursera graveolens, Zanthoxylum fagara, Pisonia floribunda, Senna pistaciifolia), on bark, 09-Mar-2006, Aptroot, A. 64966 (CDS 31546), 64964 A (CDS 31543); along the trail going up the E-slope, at the NW-side of the trail, $0^{\circ} 24^{\prime} 5^{\prime \prime} \mathrm{S}, 91^{\circ} 2^{\prime} 36^{\prime \prime} \mathrm{W}, 420 \mathrm{~m}$ alt., dry zone, open Bursera graveolens stand with an occasional Pisonia floribunda and Zanthoxylum fagara and shrubs of Macraea laricifolia and Waltheria ovata, on bark, 09-Mar-2006, Bungartz, F. 4383 (CDS 28467). VOLCÁN DARWIN: inland from Tagus Cove at the W-coast of the island, $0^{\circ} 15^{\prime} 8.693^{\prime \prime} \mathrm{S}$, $91^{\circ} 22^{\prime} 23^{\prime \prime} \mathrm{W}, 77 \mathrm{~m}$ alt., dry zone, very open Bursera forest on W-exposed slope with Scalesia affinis, Macraea laricifolia, Cordia revoluta, and Waltheria ovata among lava flows of weathered AA-lava, on bark, 17-Nov-2007, Bungartz, F. 7974 (CDS 38484), 7975 (CDS 38485); southwestern foothills, above Tagus Cove (1st campsite), $0^{\circ} 14^{\prime} 50^{\prime \prime} \mathrm{S}, 91^{\circ} 21^{\prime} 29^{\prime \prime} \mathrm{W}, 67 \mathrm{~m}$ alt., dry zone, open Bursera graveolens forest with Waltheria ovata and Macraea laricifolia, few Acacia rorudiana and Cordia lutea, along small lava flow, on bark, 11-Nov-2007, Ertz, D. 11754 (CDS 37113); southwestern slope, above Tagus Cove, $0^{\circ} 13^{\prime} 59^{\prime \prime} \mathrm{S}, 91^{\circ} 20^{\prime} 8^{\prime \prime} \mathrm{W}, 597 \mathrm{~m}$ alt., dry zone, open Bursera graveolens forest with Croton scouleri and Macraea laricifolia shrubs, few Chiococca alba and Scalesia microcephala, among lava boulders and outcrops, on bark, 16-Nov-2007, Bungartz, F. 7858 (CDS 38367). SANTA CRUZ: E-side of island, trail from parking lot to El Garrapatero beach, N-side of trail, $0^{\circ} 41^{\prime} 26^{\prime \prime} \mathrm{S}, 90^{\circ} 13^{\prime} 19^{\prime \prime} \mathrm{W}, 6 \mathrm{~m}$ alt., dry zone, open deciduous forest of Bursera graveolens, Cordia lutea, Opuntia echios with Castela galapageia and Alternanthera echinocephala and others in the understory, on bark, 16-Jun-2010, Nugra, F. 892 B (CDS 44948); Miranda, R. 962 (CDS 45159); Puerto Ayora, near Charles Darwin Research Station (CDRS), 0 44'32"S, $90^{\circ} 18^{\prime} 10^{\prime \prime} \mathrm{W}, 5 \mathrm{~m}$ alt., coastal zone, on wood, 24-May-2005, Aptroot, A. 63035 (CDS 29763); along the road from Bellavista to El Garrapatero, $\sim 2 \mathrm{~km}$ from the coast, at the campsite of the National Park, $0^{\circ} 41^{\prime} 25^{\prime \prime} \mathrm{S}, 90^{\circ} 13^{\prime} 35^{\prime \prime} \mathrm{W}, 24 \mathrm{~m}$ alt., dry zone, decidous dry lowland forest, Bursera graveolens, Acacia rorudiana, Opuntia echios, Croton scouleri, on bark, 14-Feb-
2006, Aptroot, A. 63962 (CDS 30521); Bungartz, F. 3558 (CDS 27357); on the North side of the island, along the dirt road to the ash quarry Mina Granillo Negro, $0^{\circ} 34^{\prime} 22^{\prime \prime} \mathrm{S}, 90^{\circ} 19^{\prime} 55^{\prime \prime} \mathrm{W}$, $27 \mathrm{~m}$ alt., dry zone, dry deciduous lowland forest (Bursera graveolens, Heliotropium sp., Acacia sp., Zanthoxylum fagara), on bark, 23-Feb-2006, Aptroot, A. 64486 (CDS 31058); Bungartz, F. 3877 (CDS 27759), 3880 (CDS 27762); waste deposit along road to Baltra; relevee 5.1, $0^{\circ} 34^{\prime} 60^{\prime \prime} \mathrm{S}, 90^{\circ} 21^{\prime} 17^{\prime \prime} \mathrm{W}$, $300 \mathrm{~m}$ alt., transition zone, Bursera woodland, on bark, 28-May2005, Aptroot, A. 63246 (CDS 29981); along the road from Los Gemelos towards the N-coast of the island, $\sim 1 \mathrm{~km} \mathrm{~N}$ of Los Gemelos, $0^{\circ} 37^{\prime} 22^{\prime \prime} \mathrm{S}, 90^{\circ} 22^{\prime} 47^{\prime \prime} \mathrm{W}, 584 \mathrm{~m}$ alt., transition zone, upper transition zone with open dry forest, Scalesia pedunculata, Chiococca alba, Tournefortia rufo-sericea, Cordia leucophlyctis, and Zanthoxylum fagara, on bark, 12-Feb2006, Aptroot, A. 63795 (CDS 30354). SAN CRISTÓBAL: nothern foothills of Pan de azúcar, $0^{\circ} 43^{\prime} 5^{\prime \prime} \mathrm{S}, 89^{\circ} 21^{\prime} 17^{\prime \prime} \mathrm{W}, 72 \mathrm{~m}$ alt., dry zone, dense woodland of Bursera graveolens, Piscidia carthagenensis, with Scutia spicata, Malvastrum sp. and Mentzelia aspera in the understory, on bark, 24-Apr-2007, Bungartz, F. 6469 (CDS 34686); SW foothills of Media Luna, inland from the NW-coast of the island along the trail from Galapagera to Media Luna; bottom of small crater to the NW of Media Luna, $0^{\circ} 43^{\prime} 53^{\prime \prime} \mathrm{S}, 89^{\circ} 18^{\prime} 57^{\prime \prime} \mathrm{W}, 124 \mathrm{~m}$ alt., dry zone, upper dry zone; woodland of Piscidia carthagenensis, Cordia lutea, Zanthoxylum fagara, Croton scouleri and few Bursera graveolens, on bark, 22-Apr-2007, Bungartz, F. 6245 (CDS 34457). ESPAÑOLA: along S-coast of the island, SE of Punta Suárez, $\sim 500 \mathrm{~m}$ inland from coast, $1^{\circ} 22^{\prime} 56^{\prime \prime} \mathrm{S}, 89^{\circ} 43^{\prime} 8^{\prime \prime} \mathrm{W}, 133 \mathrm{~m}$ alt., dry zone, lava cliff with Cordia lutea, Ipomoea habeliana, and frew trees of Bursera graveolens, on bark, 10-Nov-2010, Bungartz, F. 8943 (CDS 45761), 8946 (CDS 45764); along S-coast of the island, SE of Punta Suárez, $20 \mathrm{~m}$ inland from coast, $1^{\circ} 22^{\prime} 56^{\prime \prime} \mathrm{S}, 89^{\circ} 43^{\prime} 36^{\prime \prime} \mathrm{W}, 74 \mathrm{~m}$ alt., dry zone, Cordia lutea shrubland with Croton scouleri and Prosopis juliflora, on bark, 10-Nov-2010, Bungartz, F. 8899 (CDS 45717); trail from Bahía Manzanillo on the N-coast of the island to the highest point, $1^{\circ} 22^{\prime} 18^{\prime \prime} \mathrm{S}, 89^{\circ} 42^{\prime} 7^{\prime \prime} \mathrm{W}, 125 \mathrm{~m}$ alt., dry zone, Cordia lutea shrubland with some Prosopis juliflora shrubs at bottom of a basalt outcrop, on bark, 11-Nov-2010, Yánez-Ayabaca, A. 1684 (CDS 45567). FLOREANA: W of dirt road to water tank, off the main dirt road to the highlands, $1^{\circ} 16^{\prime} 56^{\prime \prime} \mathrm{S}$, $90^{\circ} 28^{\prime} 50^{\prime \prime} \mathrm{W}, 67 \mathrm{~m}$ alt., dry zone, dense Prosopis juliflora shrubland with some Castela galapageia and few trees of Bursera graveolens, on bark, 12-Jan-2011, Yánez-Ayabaca, A. 1797 (CDS 48080), 1785 (CDS 48067); Bungartz, F. 9410 (CDS 46697). SANTA FÉ: on top of lava flow at the N-coast of the island, $0^{\circ} 48^{\prime} 12^{\prime \prime} \mathrm{S}, 90^{\circ} 2^{\prime} 34^{\prime \prime} \mathrm{W}, 13 \mathrm{~m}$ alt., coastal zone, open scrubland of partly dead shrubs (Croton scouleri, Cordia lutea), few shrubby Bursera graveolens, and Opuntia echios var. barringtonensis among lava rocks, on bark, 25-Oct-2007, Bungartz, F. 7222 (CDS 37706); lava flow at the N-coast of the island, $0^{\circ} 48^{\prime} 6^{\prime \prime} \mathrm{S}, 90^{\circ} 2^{\prime} 39^{\prime \prime} \mathrm{W}, 42 \mathrm{~m}$ alt., dry zone, S-exposed side of lava flow with scarce vegetation (shrubs of Croton scouleri, Cordia lutea, few Bursera graveolens trees, and Opuntia echios var. barringtonensis), on bark, 25-Oct-2007, Bungartz, F. 7264 (CDS 37748); $0^{\circ} 48^{\prime} 2.798^{\prime \prime} \mathrm{S}, 90^{\circ} 2^{\prime} 38^{\prime \prime} \mathrm{W}, 26 \mathrm{~m}$ alt., dry zone, open scrubland of Croton scouleri with some Bursera graveolens trees, and Opuntia echios var. barringtonensis on NE-exposed side of lava flow, on bark, 25-Oct-2007, Bungartz, F. 7276 (CDS 37760). SANTIAGO: 500 m S of Bucanero, near the canyon at the northeastern foothills of Cerro Cowan (permanent monitoring plot \# 4 'Encañada abierta'), $0^{\circ} 10^{\prime} 21^{\prime} \mathrm{S}$, $90^{\circ} 49^{\prime} 30^{\prime \prime} \mathrm{W}, 70 \mathrm{~m}$ alt., dry zone, open woodland with Castela galapageia, Cordia lutea, Vallesia glabra, Opuntia galapageia, on bark, 21-Mar-2006, Aptroot, A. 65352 (CDS 31938); 0.4 km 
$\mathrm{S}$ of Santiago Bay, $0^{\circ} 14^{\prime} 30^{\prime \prime} \mathrm{S}, 90^{\circ} 51^{\prime} 30^{\prime \prime} \mathrm{W}, 7 \mathrm{~m}$ alt., dry zone, open Bursera forest on consolidated ash, on bark, 25-Apr-1971, Pike, L.H. 2538 (L-56170, COLO 263247), 2538 (OSC 53247); $5 \mathrm{~km}$ E of eastern summit, $0^{\circ} 12^{\prime} 45^{\prime \prime} \mathrm{S}, 90^{\circ} 43^{\prime} 45^{\prime \prime} \mathrm{W}, 410 \mathrm{~m}$ alt., transition zone, open Bursera forest with thickets of Clerodendron on an old lava flow on N-facing slope, on bark, 07-May1971, Pike, L.H. ID29-39 (OSC 53246); 2 km SE of Bucaneer Cove, $0^{\circ} 10^{\prime} 45^{\prime \prime} \mathrm{S}, 90^{\circ} 48^{\prime} 45^{\prime \prime} \mathrm{W}, 350 \mathrm{~m}$ alt., transition zone, Bursera forest on old lava flow, on bark, 17-May-1971, Pike, L.H. ID71-1 (OSC 53254); along the trail from Bucanero to Jaboncillos, $\sim 3 \mathrm{~km} \mathrm{SE}$ of Bucanero, $0^{\circ} 10^{\prime} 52^{\prime \prime} \mathrm{S}, 90^{\circ} 48^{\prime} 33^{\prime \prime} \mathrm{W}$, $362 \mathrm{~m}$ alt., transition zone, open woodland of large Bursera graveolens and smaller Psidium galapageium trees, grassland and basalt boulders in between, on bark, 22-Mar-2006, Bungartz, F. 4636 (CDS 28723); Aptroot, A. 65379 B (CDS 56220); cinder cone $\sim 1 \mathrm{~km}$ inland from the E-coast, at the same latitude as Bartolomé, $0^{\circ} 17^{\prime} 55^{\prime \prime} \mathrm{S}, 90^{\circ} 35^{\prime} 13^{\prime \prime} \mathrm{W}, 75 \mathrm{~m}$ alt., dry zone, ESE-exposed slope of cinder cone with very scarce vegetation of Bursera graveolens, Scutia spicata var. pauciflora and occasional Acacia trees, on wood, 20-Jul-2006, Bungartz, F. 5305 (CDS 29521); en el parte sureste de la isla, $0^{\circ} 23^{\prime} 58^{\prime \prime} \mathrm{S}$, $90^{\circ} 42^{\prime} 36^{\prime \prime} \mathrm{W}, 140 \mathrm{~m}$ alt., zona costera, sobre lava jovén, sobre corteza, 20-Jul-2006, Nugra, F. 130 (CDS 32784). PINTA: along the trail up to the summit from the S-coast, $0^{\circ} 33^{\prime} 57^{\prime \prime} \mathrm{N}$, $90^{\circ} 44^{\prime} 51^{\prime \prime} \mathrm{W}, 215 \mathrm{~m}$ alt., transition zone, dense vegetation of Bursera graveolens, Croton scouleri, Scalesia baurii, Pisonia floribunda, and Zanthoxylum fagara, on bark, 25-Feb-2007, Bungartz, F. 5690 (CDS 33327).

\section{New synonym in Huneckia not reported from the Galapagos}

Huneckia pollinii (A. Massal.) S.Y. Kondr., Kärnefelt, A. Thell, Elix, J. Kim, A.S. Kondratyuk \& Hur

\section{MycoBank MB 807195}

Basionym: Blastenia pollinii A. Massal., Atti Istit. Veneto, ser. 2, vol. 3, App. 3: 111, 27. 1852; MycoBank MB 379948.

New synonym: Huneckia rheinigera S. Y. Kondr., Kärnefelt, A. Thell, Elix, J. Kim, A. S. Kondratyuk \& Hur, Acta Botanica Hungarica 56: 111. 2014; MycoBank MB 807196. Caloplaca rheinigera Elix \& S.Y. Kondr. Bibliotheca Lichenologica 95: 375. 2007; MycoBank MB 529540.
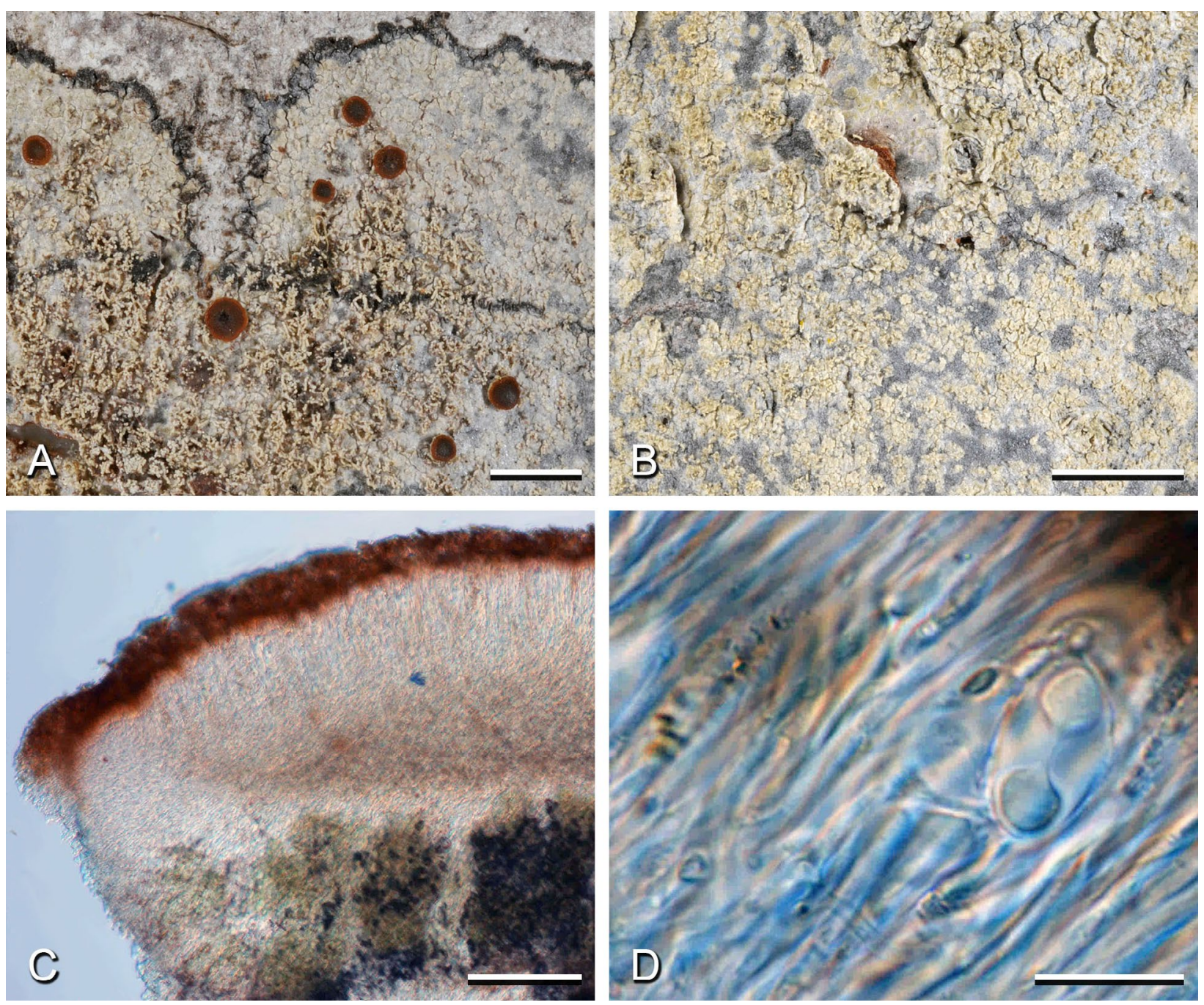

Figure 6. Huneckia wrightii. A - fertile specimen; pale creamy white thallus with rust-red apothecia and \pm coralloid isidia, developing on a membranaceous, black hypothallus, along the margin transitioning into a carbonaceous prothallus (Bungartz, F. 5690, CDS 33327); B - specimen without apothecia; pale creamy white thallus of \pm coralloid isidia on a black, membranaceous hypothallus (Ertz, D. 11754, CDS 37113); C - apothecial section: zeorine, inner part of the proper exciple hyaline, outer, upper part \pm intensifying wine-red in C, pigmentation contiguous with the epihymenium, thalline exciple below with irregular clusters of crystal and trebouxioid green algae, colorless along the outside [DIC, bleached in chlorine solution] (Aptroot, A. 63246, CDS 29981); D - hymenium with an ellipsoid, broadly septate ascospore [DIC, in water] (Aptroot, A. 64966, CDS 31546). Scales: $\mathrm{A}-\mathrm{B}=2 \mathrm{~mm} ; \mathrm{C}=100 \mu \mathrm{m} ; \mathrm{D}=10 \mu \mathrm{m}$. 
Taxonomic Note: When Huneckia rheinigera was described from Australia (Kondratyuk et al. 2007), no connection to $H$. pollinii was made except to Blastenia ferruginea, possibly because of the special secondary chemistry found in H. rheinigera. However, the compounds chrysophanol, rhein and chrysophanal are present also in $H$. pollinii and the analysis of their ITS sequences (Fig. 2) shows that $H$. rheinigera is well imbedded in the clade of $H$. pollinii.

Lacrima Bungartz, Arup \& Søchting, gen. nov.

\section{MycoBank MB 836938}

Generic type: Lacrima epiphora (Taylor) Bungartz, Søchting $\&$ Arup, ibid.

Diagnosis. Thallus saxicolous, crustose, rimose to areolate, or poorly developed, often isidiate. Apothecia lecanorine to zeorine, asci clavate, of Teloschistes-type with 8 spores. Ascospores polaribilocular, with wide septum. Molecular data support its isolated position in the subfamily Caloplacoideae.

Chemistry. Chlorinated anthraquinones, mainly fragilin present in the apothecia and in some species also within the thallus.

Etymology. Named for the characteristic 'tear'-shaped isidia (cylindrical, but slightly tapered at their base), present in some, but not all of the species.

Known distribution. The genus is so far recorded from the Neotropics (Central America and the Galapagos Islands), and in North America from the Sonoran Desert Region.

Lacrima aphanotripta (Nyl.) Bungartz, Søchting \& Arup, comb. nov.

(Figs 1-2, 7A-D)

\section{MycoBank MB 836940}

Basionym: Lecanora aphanotripta Nyl., Lich. Japon.: 104. 1890; MycoBank MB 387633.

Description. Thallus thin and very poorly developed, either as a whitish to pale bluish green, membranaceous hypothallus, or as a waxy, continuous to barely rimose crust, not distinctly delimited, effuse; surface dark olive gray, smooth, dull, epruinose, very densely covered by slightly darker, small, granular to \pm coralloid to almost subsquamulose isidia that are irregularly grouped and $\sim 40 \mu \mathrm{m}$ thick. Apothecia orange to rusty orange, sparse, dispersed, immersed between the isidia, up to $1 \mathrm{~mm}$ in diam, 'zeorine' (i.e., with both a distinct thalline and proper margin); thalline margin composed of dark olive gray, irregularly granular isidia, epruinose, $\mathrm{C}-, \mathrm{K}-$; proper margin $\sim 0.1 \mathrm{~mm}$ thick, initially prominent, later level with the disc, circular to \pm flexuose, orange, slightly paler than the disc, epruinose (but in parts reacting $\mathrm{C}+$ red); disc plane to very slightly convex, deep orange to rusty orange, epruinose, $\mathrm{C}-, \mathrm{K}+$ purple; epihymenium with orange pigment granules, $\mathrm{K}+$ purple, $\mathrm{C}+$ red, contiguous with the outer exciple; hymenium hyaline, not inspersed; proper exciple differentiated into an inner part lacking crystals, and an outer part with orange pigment granules, $\mathrm{K}+$ purple, $\mathrm{C}+$ red; thalline exciple in section not well developed and disintegrating; subhymenium and hypothecium not differentiated, hyaline, not inspersed; asci clavate, Teloschistes-type; ascospores 8/ascus, polaribilocular, ellipsoid to broadly ellipsoid, (7.0-)8.8-13.3(-16.3) $\times(3.5-) 4.8-7.8(-9.8) \mu \mathrm{m}$, with a thick, (2.0-)3.0-6.1(8.9) $\mu \mathrm{m}$ wide septum $(\mathrm{n}=42)$. Pycnidia not observed.

Chemistry. Thallus and thalline margin $\mathrm{P}_{-}, \mathrm{K}-, \mathrm{C}-$, $\mathrm{KC}-$, UV-(dull); apothecial disc and proper margin $\mathrm{P}-$, $\mathrm{K}+$ purple, $\mathrm{C}-, \mathrm{KC}+$ purplish (fading), $\mathrm{UV}-$ (dull); no secondary metabolites detected in the thallus, apothecia with 7-chloroemodin and fragilin.

Ecology and distribution. According to Wetmore (2004), known from Mexico through Central America (Caribbean) into South America (Brazil). In Galapagos, the species is currently known only from the humid zone along the crater rim of Volcán Alcedo, where it appears to be a relict species surviving on few, isolated Zanthoxylum fagara and Scalesia microscephala trees. Both these substrates are remnants of vegetation now recovering from excessive grazing by goats that were only recently eradicated.

Notes. Based on its ITS, L. aphanotripta belongs to the epiphora-clade together with L. galapagoensis and L. epiphora (Figs 1-2). Specimens lacking apothecia may be confused with some species of Phyllopsora, which, however, form squamules developing from a strongly blackened, not whitish to pale bluish green hypothallus.

Specimens examined from Ecuador, Galápagos. VOLCÁN ALCEDO, ISABELA: on top of the crater rim, $0^{\circ} 27^{\prime} 33^{\prime \prime} \mathrm{S}$, $91^{\circ} 6^{\prime} 49^{\prime \prime} \mathrm{W}, 1051 \mathrm{~m}$ alt., humid zone, disturbed by former grazing of goats therefore scattered trees (Zanthoxylum fagara, Scalesia microcephala, Tournefortia rufo-sericea), on bark, 05-Mar-2006, Bungartz, F. 4100 (CDS 28068); outer SE-exposed slope and crater rim, $0^{\circ} 27^{\prime} 29^{\prime \prime} \mathrm{S}, 91^{\circ} 7^{\prime} 19^{\prime \prime} \mathrm{W}, 1089 \mathrm{~m}$ alt., humid zone, disturbed by former grazing of goats therefore scattered trees (Tournefortia rufo-sericea, Zanthoxylum fagara), on bark, 05-Mar-2006, Bungartz, F. 4051 (CDS 27981); Aptroot, A. 65085 (CDS 31667); upper NNW-exposed slope inside the crater, $0^{\circ} 27^{\prime} 27^{\prime \prime} \mathrm{S}, 91^{\circ} 7^{\prime} 23^{\prime \prime} \mathrm{W}, 1055 \mathrm{~m}$ alt., humid zone, open vegetation with Adianthus concinnum, and scattered shrubs of Tournefortia rufo-sericea among basalt rocks, on bark, 05-Mar-2006, Aptroot, A. 64874 (CDS 31451).

Lacrima epiphora (Taylor) Bungartz, Søchting \& Arup, comb. nov.

(Figs 1-2, 8A-D)

\section{MycoBank MB 836939}

Basionym: Lecanora epiphora Taylor, London J. Bot. 6: 159. 1847; MycoBank MB 388181.

Description. Thallus thin and poorly developed as a waxy, continuous to rimose layer, developing from a smooth blackish hypothallus, not distinctly delimited, effuse; surface yellow-orange, smooth, \pm shiny, epruinose, very densely covered by small, granular to \pm coralloid isidia, $\sim 50 \mu \mathrm{m}$ thick. Apothecia typically scarce and frequently absent, dispersed to loosely aggregated, occasionally deforming one another, sessile, up to $1 \mathrm{~mm}$ in diam., lecanorine to indistinctly 'zeorine' (e.g., the proper 
margin can occasionally be distinguished as an additional, non-isidiate rim); thalline margin concolorous with the thallus, with age almost entirely dissolved into granular or even \pm cylindrical isidia, regularly to irregularly circular in outline, pale yellow to orange, epruinose, $\mathrm{C}-$ - $\mathrm{K}-$; proper margin typically ill-defined, deep orange to ferruginous, concolorous with the disc, epruinose, $\mathrm{C}-, \mathrm{K}-$; disc flat to slightly convex, deep orange to ferruginous, densely covered by coarse orange pruina, $\mathrm{C}-( \pm$ weakly red, indistinct), $\mathrm{K}+$ purple; epihymenium with orange pigment granules, $\mathrm{C}-$ ( \pm orange red intensifying), $\mathrm{K}+$ purple, contiguous with the outer exciple; hymenium hyaline, not inspersed; proper exciple extending laterally from the colorless hypothecium as a \pm distinct hyaline layer, apically with orange pigment granules, $\mathrm{C}-( \pm$ orange red intensifying), $\mathrm{K}+$ purple, thalline exciple differentiated into an inner part abundantly filled with trebouxioid photobionts and occasionally few, small, colorless crystals, dissolving in $\mathrm{K}$, and an outer part that with age laterally disintegrates; subhymenium thick, well developed, very pale brown, of intricately interwoven hyphae, structurally distinct from the narrow, hyaline hypothecium of more parallel hyphae, both not inspersed; asci clavate, Teloschistes-type; ascospores 8/ascus, polaribilocular, narrowly to broadly ellipsoid (9.7-) $11.4-16.0(-20.1) \times$ (5.8-)6.9-8.6(-9.2) $\mu \mathrm{m}$, with a thick, (3.5-)4.4-7.3(-9.4) $\mu \mathrm{m}$ wide septum $(\mathrm{n}=46)$. Pycnidia not observed (in the Galapagos material).

Chemistry. Thallus and apothecia $\mathrm{P}-, \mathrm{K}+$ purple, $\mathrm{C}-$, $\mathrm{KC}-$, UV-(dull); with a large proportion of fragilin and a smaller proportion of parietin; additionally chlorinated accessory metabolites such as 7-chloroemodin and 7-chloroemodic acid are occasionally also detected.

Ecology and distribution. Lacrima epiphora occurs in neotropical regions of North, Central and South America (see Wetmore, 2004). In Galapagos, it is one of the most common corticolous species, rarely also occurring on wood or rock, and common throughout the dry zone and
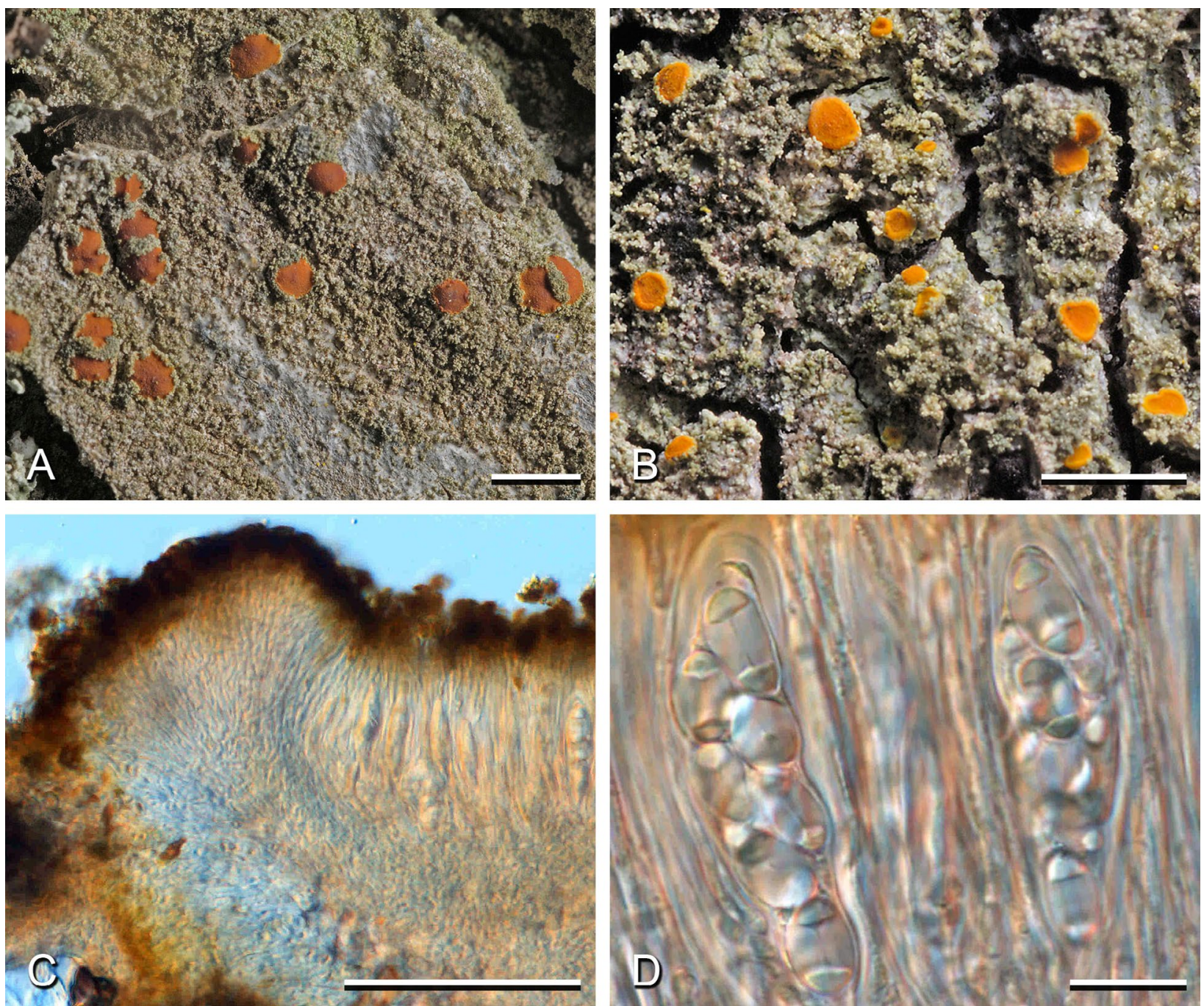

Figure 7. Lacrima aphanotripta. A - olive, densely granular isidiate thallus on a whitish to bluish green, membranaceous hypothallus, with rust-red apothecia, with a thin, rust-red proper margin and a thick, well developed granular-isidiate thalline margin (Bungartz 4051, CDS 27981); B - pale grayish white rimose thallus, abundantly isidiate, olive isidiate protuberances \pm coralloid to almost subsquamulose, with adnate orange apothecia, with a distinct orange proper margin and a poorly developed, indistinct thalline margin of few granular isidia (Bungartz, F. 4100, CDS 28068); $\mathrm{C}$ - apothecial section: appearing biatorine, the thalline exciple indistinct or disintegrating, the outer part of the proper exciple and epihymenium orange brown, the inner part hyaline [differential interference contrast (DIC), in water] (Aptroot, A. 64874, CDS 31451); D - asci with oblong to ellipsoid ascospores, septum broad [DIC, in water] (Aptroot, A. 64874, CDS 31451). Scales: A-B = $2 \mathrm{~mm}$; C $=100 \mu \mathrm{m} ; \mathrm{D}=10 \mu \mathrm{m}$. 
lower transition zone, occasionally also in upper transition zone, rarely in the humid zone. It is particularly common on Bursera and Erythrina, typically in wind- and rain-exposed, but often \pm shaded habitats.

Notes. Lacrima epiphora is characterized by a densely isidiate, yellow-orange thallus, a relatively pale color due to the high content of fragilin. In Galapagos, according to the ITS sequences obtained here, the species appears closely related to L. galapagoensis and L. aphanotripta (Fig. 2). Weber (1986) originally reported it as Caloplaca byrsonimae (Malme) Zahlbr.

Specimens examined from Ecuador, Galápagos. ISABELA, VOLCÁN ALCEDO: along both sides of the trail going up the E-slope, at the NW-side of the barranco, $0^{\circ} 24^{\prime} 5^{\prime \prime} \mathrm{S}$, $91^{\circ} 2^{\prime} 53^{\prime \prime} \mathrm{W}, 480 \mathrm{~m}$ alt., dry zone, open Bursera graveolens stand, with an occasional Pisonia floribunda, and Zanthoxylum fagara in between and shrubs of Macraea laricifolia, Waltheria ovata, and Senna pistaciifolia, on bark, 10-Mar-2006, Bungartz, F. 4421 (CDS 28506); plain at the base of the outer E-exposed slope, along the trail going up to the rim, $0^{\circ} 24^{\prime} 47^{\prime \prime} \mathrm{S}, 91^{\circ} 4^{\prime} 12^{\prime \prime} \mathrm{W}$, $768 \mathrm{~m}$ alt., transition zone, very open Psidium galapageium stand with occasional Croton scouleri and Zanthoxylum fagara, grassland and open soil in between, on bark, 08-Mar-2006, Bungartz, F. 4315 (CDS 28389); outer SE-exposed slope and crater rim, $0^{\circ} 27^{\prime} 29^{\prime \prime} \mathrm{S}, 91^{\circ} 7^{\prime} 19^{\prime \prime} \mathrm{W}, 1089 \mathrm{~m}$ alt., humid zone, disturbed by former grazing of goats therefore scattered trees (Tournefortia rufo-sericea, Zanthoxylum fagara), on bark, 05-Mar-2006, Bungartz, F. 4073 (CDS 28003); in the crater, $0^{\circ} 27^{\prime} 9^{\prime \prime} \mathrm{S}, 91^{\circ} 6^{\prime} 41^{\prime \prime} \mathrm{W}, 780 \mathrm{~m}$ alt., transition zone, mostly Bursera graveolens and dense scrub on uneven lava, on bark, 07-Mar2006, Aptroot, A. 64755 (CDS 31330); on the crater rim near the hut, $0^{\circ} 26^{\prime} 33^{\prime \prime} \mathrm{S}, 91^{\circ} 5^{\prime} 31^{\prime \prime} \mathrm{W}, 1100 \mathrm{~m}$ alt., humid zone, Pteridium arachnoideum and Stachytarpheta cayennensis, scattered low shrubs of Tournefortia rufo-sericea and outcrops of basalt tuff in between, on rock, 07-Mar-2006, Aptroot, A. 65284 (CDS 31870). VOLCÁN CERRO AZUL: along the first few meters of the path from the Caseta del Parque to Caleta Iguana, $0^{\circ} 58^{\prime} 44^{\prime \prime} \mathrm{S}, 91^{\circ} 26^{\prime} 46^{\prime \prime} \mathrm{W}, 12 \mathrm{~m}$ alt., dry zone, dense scrubland of mostly Clerodendrum molle, some Gossypium darwinii and Croton scouleri, very sparse Bursera graveolens trees, on bark, 09-May-2012, Bungartz, F. 10532 (CDS 52544). VOLCÁN DARWIN: southwestern slope, above Tagus Cove, $0^{\circ} 14^{\prime} 15^{\prime \prime} \mathrm{S}$, $91^{\circ} 20^{\prime} 40^{\prime \prime} \mathrm{W}, 351 \mathrm{~m}$ alt., dry zone, open Bursera graveolens forest with Croton scouleri, Macraea laricifolia and Waltheria ovata, few trees of Acacia rorudiana, on bark, 16-Nov-2007, Ertz, D. 12021 (CDS 37380); southwestern slope, above Tagus Cove, $0^{\circ} 13^{\prime} 59^{\prime \prime} \mathrm{S}, 91^{\circ} 20^{\prime} 8^{\prime \prime} \mathrm{W}, 597 \mathrm{~m}$ alt., dry zone, open Bursera graveolens forest with Croton scouleri and Macraea laricifolia shrubs, few Chiococca alba and Scalesia microcephala, among lava boulders and outcrops, on wood, 16-Nov-2007, Bungartz, F. 7790 (CDS 38299), 7789 (CDS 38298); 0¹3'27"S, $91^{\circ} 19^{\prime} 19^{\prime \prime} \mathrm{W}, 874 \mathrm{~m}$ alt., transition zone, top of lava flow in open scrubland of Croton scouleri and Dodonaea viscosa with Cordia revoluta and some Opuntia insularis, on bark, 15-Nov2007, Bungartz, F. 7732 (CDS 38236); $0^{\circ} 14^{\prime} 50^{\prime \prime} \mathrm{S}, 91^{\circ} 21^{\prime} 29^{\prime \prime} \mathrm{W}$, $67 \mathrm{~m}$ alt., dry zone, open Bursera graveolens forest with Waltheria ovata and Macraea laricifolia, few Acacia rorudiana and Cordia lutea, along small lava flow, on bark, 11-Nov-2007, Bungartz, F. 7344 (CDS 37831). VOLCÁN SIERRA NEGRA: area around the Muro de las Lagrimas, $\sim 5 \mathrm{~km} \mathrm{~W}$ of Puerto Villamil, $0^{\circ} 57^{\prime} 54^{\prime \prime} \mathrm{S}, 91^{\circ} 0^{\prime} 48^{\prime \prime} \mathrm{W}, 81 \mathrm{~m}$ alt., dry zone, open Bursera graveolens forest on NNE-exposed slope with Opuntia echios, Scalesia affinis and Lantana peduncularis, on bark,
17-Aug-2008, Bungartz, F. 8421 (CDS 41067); along dirt road from Puerto Villamil to crater of Sierra Negra, $0^{\circ} 55^{\prime} 12^{\prime \prime} \mathrm{S}$, $90^{\circ} 59^{\prime} 38^{\prime \prime} \mathrm{W}, 30 \mathrm{~m}$ alt., dry zone, at bottom of old lava flow with scattered vegetation (Bursera graveolens, Opuntia echios, and Waltheria ovata), on bark, 10-Sep-2007, Bungartz, F. 6967 (CDS 36471), 7003 (CDS 36508); $100 \mathrm{~m} \mathrm{~N}$ of El Mango, $0^{\circ} 52^{\prime} 50^{\prime \prime} \mathrm{S}, 91^{\circ} 0^{\prime} 43^{\prime \prime} \mathrm{W}, 165 \mathrm{~m}$ alt., transition zone, open shrubland of Croton scouleri, on bark, 15-Aug-2008, Bungartz, F. 8301 (CDS 40947); around the parking place at the end of the dirt road to the crater of Sierra Negra, $0^{\circ} 49^{\prime} 45^{\prime \prime} \mathrm{S}, 91^{\circ} 5^{\prime} 17^{\prime \prime} \mathrm{W}$, $913 \mathrm{~m}$ alt., humid zone, farming areas, with small trees of Psidium guajava, slope $25^{\circ} \mathrm{SE}, 14-\mathrm{Aug}-2008$, Clerc, P. 08-155 (CDS 40009. PINTA: along the trail up to the summit from the S-coast, $0^{\circ} 34^{\prime} 9^{\prime \prime} \mathrm{N}, 90^{\circ} 44^{\prime} 59^{\prime \prime} \mathrm{W}, 252 \mathrm{~m}$ alt., transition zone, dense vegetation of Pisonia floribunda, Zanthoxylum fagara, and Bursera graveolens, on bark, 25-Feb-2007, Bungartz, F. 5714 (CDS 33352), 5715 (CDS 33353); $0^{\circ} 34^{\prime} 22^{\prime \prime} \mathrm{N}, 90^{\circ} 45^{\prime} 3^{\prime \prime} \mathrm{W}, 329 \mathrm{~m}$ alt., transition zone, open woodland of Zanthoxylum fagara, Pisonia floribunda, and few Trema micrantha; grasses and Justicia galapagana in the understory, on bark, 27-Feb-2007, Bungartz, F. 5881 (CDS 33557); $0^{\circ} 34^{\prime} 39^{\prime \prime} \mathrm{N}, 90^{\circ} 45^{\prime} 7^{\prime \prime} \mathrm{W}, 436 \mathrm{~m}$ alt., humid zone, dense forest of Zanthoxylum fagara, few Pisonia floribunda, and the vine Cissampelos pareira; Justicia galapagana in understory, on bark, 26-Feb-2007, Bungartz, F. 5786 (CDS 33459); SW-part of the island, along trail going up the southwestern slope to Las Pampas on the western saddle, $0^{\circ} 34^{\prime} 29^{\prime \prime} \mathrm{N}$, $90^{\circ} 45^{\prime} 56^{\prime \prime} \mathrm{W}, 360 \mathrm{~m}$ alt., transition zone, open forest of Pisonia floribunda, Zanthoxylum fagara and Croton scouleri with Alternanthera filifolia, Paspalum galapageium and Cissampelos pareira in the understory, on bark, 30-Jan-2008, Nugra, F. 590 (CDS 38968). PINZÓN: along the trail going up from Playa Escondida, N- to W-facing cliff above a crater, $0^{\circ} 36^{\prime} 29^{\prime \prime} \mathrm{S}$, $90^{\circ} 40^{\prime} 14^{\prime \prime} \mathrm{W}, 318 \mathrm{~m}$ alt., transition zone, dry transition zone with Cordia lutea, Croton scouleri, and at the bottom of the cliff also Scalesia baurii ssp. baurii, on bark, 16-Feb-2006, Aptroot, A. 64054 (CDS 30615). SANTA CRUZ: on trail to barranco near seismic station, dry zone, on bark, 12-Apr-1976, Weber, W.A. s.n. (CDS 10826), s.n. (QCA); vicinity of Academy Bay, 15-Feb-1964, Weber, W.A. 165 (L-40365, COLO 188562), 347 (L-40451, COLO 193409); top of first barranca along old trail, dry zone, on bark, 15-Feb-1964, Weber, W.A. 417 (L-40563, COLO 192474); trail to La Copa (= Media Luna), humid zone, on bark, 15-Feb-1964, Weber, W.A. 125 (L-40386, COLO 188559); vicinity of seismic station, dry zone, on bark, 15-Feb-1964, Weber, W.A. 20 (L-40205, COLO 189450); near lava tube outside Puerto Ayora along Bellavista road, $0^{\circ} 43^{\prime} 55^{\prime \prime} \mathrm{S}$, $90^{\circ} 19^{\prime} 44^{\prime \prime} \mathrm{W}, 95 \mathrm{~m}$ alt., dry zone, dry zone vegetation with Bursera graveolens and Zanthoxylum fagara, on bark, 25-Feb-2006, Aptroot, A. 64629 A (CDS 31202); The Cracks, Academy Bay, 14-Jun-1971, Weber, W.A. s.n. (L-54815, COLO 255243); along the road from Bellavista to El Garrapatero, $22 \mathrm{~km}$ from the coast, at the campsite of the National Park, $0^{\circ} 41^{\prime} 25^{\prime \prime} \mathrm{S}$, $90^{\circ} 13^{\prime} 35^{\prime \prime} \mathrm{W}, 24 \mathrm{~m}$ alt., dry zone, decidous dry lowland forest, Bursera graveolens, Acacia rorudiana, Opuntia echios, Croton scouleri, on bark, 14-Feb-2006, Aptroot, A. 63961 (CDS 30520); along the trail from Puerto Ayora to Bahía Tortuga, $0^{\circ} 44^{\prime} 48^{\prime \prime} \mathrm{S}$, $90^{\circ} 19^{\prime} 14^{\prime \prime} \mathrm{W}, 28 \mathrm{~m}$ alt., dry zone, decidous forest in dry zone; with Bursera graveolens, Acacia rorudiana, and Opuntia echios; over basalt, on bark, 05-Jan-2006, Bungartz, F. 3327 (CDS 26994); Puerto Ayora, near Charles Darwin Research Station (CDRS), $0^{\circ} 44^{\prime} 32^{\prime \prime} \mathrm{S}, 90^{\circ} 18^{\prime} 10^{\prime \prime} \mathrm{W}, 5 \mathrm{~m}$ alt., coastal zone, on bark, 24-May-2005, Aptroot, A. 63046 (CDS 29774). SAN CRISTÓBAL: road leading out of Wreck Bay, on bark, 20-May1976, Lanier, J. s.n. (L-63715, COLO 298464); rim of crater to the NW of Media Luna, inland from the NW-coast, $0^{\circ} 43^{\prime} 51^{\prime \prime} \mathrm{S}$, $89^{\circ} 18^{\prime} 55^{\prime \prime} \mathrm{W}, 149 \mathrm{~m}$ alt., transition zone, lower transition zone; 
basalt cliffs of inner and outer crater rim with scarce vegetation, on rock, 22-Apr-2007, Bungartz, F. 6298 (CDS 3451); SW foothills of Media Luna, inland from the NW-coast of the island along the trail from Galapagera to Media Luna; bottom of small crater to the NW of Media Luna, $0^{\circ} 43^{\prime} 53^{\prime \prime} \mathrm{S}, 89^{\circ} 18^{\prime} 57^{\prime \prime} \mathrm{W}, 124 \mathrm{~m}$ alt., dry zone, upper dry zone; woodland of Piscidia carthagenensis, Cordia lutea, Zanthoxylum fagara, Croton scouleri and few Bursera graveolens, on bark, 22-Apr-2007, Bungartz, F. 6248 (CDS 34460); Pan de Azúcar, inland from Bahía Sardinas at the NW-coast of the island, $0^{\circ} 43^{\prime} 12^{\prime \prime} \mathrm{S}, 89^{\circ} 21^{\prime} 14^{\prime \prime} \mathrm{W}, 143 \mathrm{~m}$ alt., dry zone, NE-exposed slope on hill of consolidated tuff with low vegetation of herbs, on bark, 24-Apr-2007, Bungartz, F. 6452 (CDS 34669); northwestern foothills of Media Luna, inland from the NW-coast, $0^{\circ} 43^{\prime} 41^{\prime \prime} \mathrm{S}, 89^{\circ} 18^{\prime} 44^{\prime \prime} \mathrm{W}, 75 \mathrm{~m}$ alt., dry zone, open woodland of Cordia lutea and Bursera graveolens, on bark, 22-Apr-2007, Bungartz, F. 6182 (CDS 34394); along trail between entrance to Cerro Pelado and Cerro Partido, trail to El Ripioso, $0^{\circ} 51^{\prime} 38^{\prime \prime} \mathrm{S}, 8^{\circ} 27^{\prime} 37^{\prime \prime} \mathrm{W}, 383 \mathrm{~m}$ alt., transition zone, dry and dense scrubland of Macraea laricifolia, Scalesia pedunculata, Croton scouleri, and Zanthoxylum fagara, on bark, 28-Apr-2007, Bungartz, F. 6673 (CDS 34909); SW foothills of Media Luna, inland from the NW-coast of the island along the trail from Galapagera to Media Luna; bottom of small crater to the NW of Media Luna, $0^{\circ} 43^{\prime} 53^{\prime \prime} \mathrm{S}, 89^{\circ} 18^{\prime} 57^{\prime \prime} \mathrm{W}, 124 \mathrm{~m}$ alt., dry zone, upper dry zone; woodland of Piscidia carthagenensis, Cordia lutea, Zanthoxylum fagara, Croton scouleri and few Bursera graveolens, on bark, 22-Apr-2007, Bungartz, F. 6269 (CDS 34481); Cerro Colorado, enclosure for Calandrinia galapagosa near the viewpoint on the top, $0^{\circ} 54^{\prime} 58^{\prime \prime} \mathrm{S}, 89^{\circ} 26^{\prime} 5^{\prime \prime} \mathrm{W}, 130 \mathrm{~m}$ alt., transition zone, open scrubland of mostly Croton scouleri, Waltheria ovata, and Macraea laricifolia on W-exposed cinder cone, on bark, 29-Apr-2007, Bungartz, F. 6757 (CDS 35008); crest of Cerro Tortuga, $\sim 4 \mathrm{~km}$ inland from the NW-coast, $0^{\circ} 44^{\prime} 54^{\prime \prime} \mathrm{S}, 8^{\circ} 23^{\prime} 32^{\prime \prime} \mathrm{W}, 116 \mathrm{~m}$ alt., dry zone, open Piscidia carthagenensis woodland with few Bursera graveolens and dense understory of Croton scouleri, Cordia lutea, and Mentzelia aspera on rocky SE-exposed slope of hill, on bark, 25-Apr-2007, Bungartz, F. 6524 (CDS 34742); along the trail from Galapagera at the NW-coast of the island to Media Luna, $0^{\circ} 42^{\prime} 41^{\prime \prime} \mathrm{S}, 89^{\circ} 18^{\prime} 15^{\prime \prime} \mathrm{W}$, 33 m alt., dry zone, open woodland of Piscidia carthagenensis, Bursera graveolens, and Gossypium darwinii shrubs, on bark, 22-Apr-2007, Bungartz, F. 6315 (CDS 34530). SANTIAGO: $\mathrm{E}$ of salt lake at Santiago Bay, $0^{\circ} 14^{\prime} 25^{\prime \prime} \mathrm{S}, 90^{\circ} 49^{\prime} 40^{\prime \prime} \mathrm{W}, 70 \mathrm{~m}$ alt., dry zone, open Bursera forest on pahoehoe lava flow, 30-Apr-1971, Pike, L.H. 2678 (L-56169, COLO 263246); $0^{\circ} 14^{\prime} 25^{\prime \prime} \mathrm{S}, 90^{\circ} 48^{\prime} 50^{\prime \prime} \mathrm{W}, 170 \mathrm{~m}$ alt., transition zone,
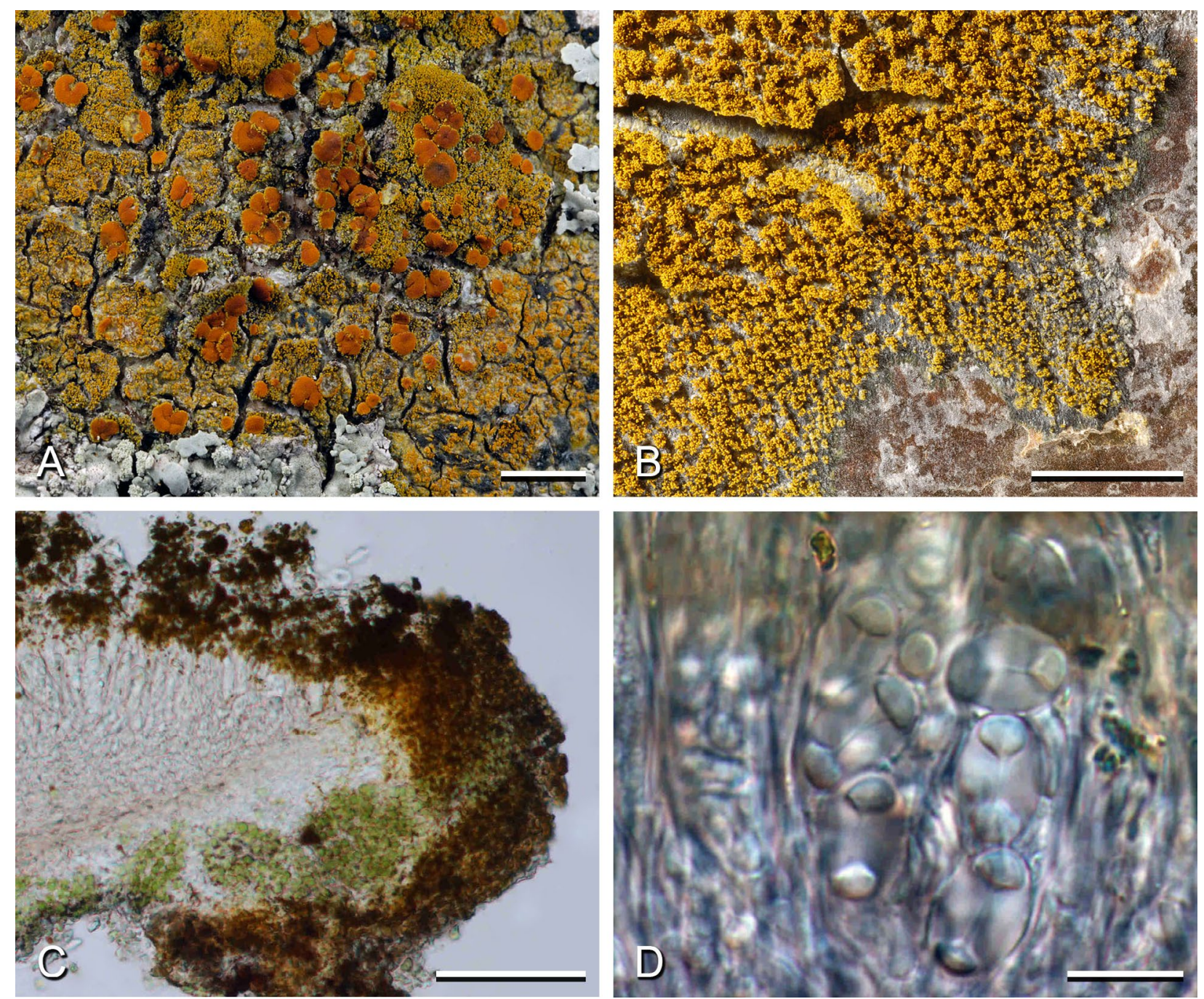

Figure 8. Lacrima epiphora. A - abundantly isidiate, yellow-orange thallus with deep orange apothecia (Bungartz, F. 5714, CDS 33352); B thallus almost entirely composed of isidia on a white to blackened membranaceous hypothallus (Bungartz, F. 6315, CDS 34530); C - apothecial section: lecanorine, outer thalline exciple and epihymenium brownish orange, inner thalline exciple abundantly filled with trebouxioid green algae, hypothecium hyaline, laterally extending into inner, proper exciple, apically orange brown [not in DIC, in water] (Aptroot, A. 64755, CDS 31330); D - asci with broadly ellipsoid ascospores, septum broad [DIC, in water] (Nugra, F. 590, CDS 38968). Scales: A-B = 2 mm; $\mathrm{C}=100 \mu \mathrm{m} ; \mathrm{D}=10 \mu \mathrm{m}$. 
Bursera-Psidium forest on pahoehoe lava flow, on bark, 30-Apr1971, Pike, L.H. ID16-3 (OSC 53461); $5 \mathrm{~km}$ inland from the E-coast, \pm at the same latitude as Bahía Sullivan, $0^{\circ} 16^{\prime} 52^{\prime \prime} \mathrm{S}$, $90^{\circ} 37^{\prime} 17^{\prime \prime} \mathrm{W}, 175 \mathrm{~m}$ alt., dry zone, rubble of older lava with very scarce vegetation of few Bursera graveolens trees, Macraea laricifolia, and Mentzelia aspera, on wood, 16-Jul-2006, Bungartz, F. 5043 (CDS 29256); 7 km inland from the E-coast, \pm at the same latitude as Bahía Sullivan, $0^{\circ} 17^{\prime} 4^{\prime \prime} \mathrm{S}, 90^{\circ} 38^{\prime} 18^{\prime \prime} \mathrm{W}$, 192 m alt., dry zone, scrubland of Castela galapageia and Macraea laricifolia with occasional trees, mostly Bursera graveolens and few Pisonia floribunda, on bark, 17-Jul-2006, Bungartz, F. 5167 (CDS 29380), 5109 (CDS 29322), 5178 (CDS 29391); along the trail from Bucanero to Jaboncillos, $\sim 3 \mathrm{~km} \mathrm{SE}$ of Bucanero, $0^{\circ} 10^{\prime} 52^{\prime \prime} \mathrm{S}, 90^{\circ} 48^{\prime} 33^{\prime \prime} \mathrm{W}, 362 \mathrm{~m}$ alt., transition zone, open woodland of large Bursera graveolens and smaller Psidium galapageium trees, grassland and basalt boulders in between, on bark, 22-Mar-2006, Aptroot, A. 65388 (CDS 31974); Bungartz, F. 4605 (CDS 28692). FLOREANA: trail from Black Beach to highlands, on bark, 25-Apr-1976, Weber, W.A. s.n. (L-62929, COLO 294593); trail going to Post Office Bay off the dirt road between highlands and Puerto Velasco Ibarra, $1^{\circ} 15^{\prime} 54^{\prime \prime} \mathrm{S}, 90^{\circ} 26^{\prime} 30^{\prime \prime} \mathrm{W}, 194 \mathrm{~m}$ alt., dry zone, dense Prosopis juliflora shrubland with Waltheria ovata, Gossypium darwinii, some Bursera trees and one single Pisonia floribunda tree, on bark, 14-Jan-2011, Bungartz, F. 9592 (CDS 46871); 1¹7'17"S, $90^{\circ} 26^{\prime} 35^{\prime \prime} \mathrm{W}, 360 \mathrm{~m}$ alt., transition zone, low and dense forest of Croton scouleri, Clerodendrum molle, Zanthoxylum fagara, and Macraea laricifolia, occasional Pisonia floribunda trees and epiphytic orchids (Ionaspis), on bark, 25-Jan-2011, Bungartz, F. 10234 (CDS 47653); W of dirt road to water tank, off the main dirt road to the highlands, $1^{\circ} 16^{\prime} 56^{\prime \prime} \mathrm{S}, 90^{\circ} 28^{\prime} 50^{\prime \prime} \mathrm{W}$, $67 \mathrm{~m}$ alt., dry zone, dense Prosopis juliflora shrubland with some Castela galapageia and few trees of Bursera graveolens, on bark, 12-Jan-2011, Yánez-Ayabaca, A. 1784 (CDS 48066); Bungartz, F. 9396 (CDS 46683). ESPAÑOLA: trail from Bahía Manzanillo on the N-coast of the island to the highest point, $1^{\circ} 22^{\prime} 18^{\prime \prime} \mathrm{S}, 89^{\circ} 42^{\prime} 7^{\prime \prime} \mathrm{W}, 125 \mathrm{~m}$ alt., dry zone, Cordia lutea shrubland with some Prosopis juliflora shrubs at bottom of basalt outcrop, on bark, 11-Nov-2010, Bungartz, F. 9141 (CDS 45959).

Lacrima galapagoensis Bungartz \& Søchting, sp. nov.

(Figs 1-2, 9A-D)

\section{MycoBank MB 836941}

Diagnosis: A species with dark orange to rusty-orange apothecia on a lead- to olive-gray, rimose to rimose-areolate thallus, superficially similar and closely related to Lacrima sonorae from California, but distinguished by its different ITS sequence.

Type: Ecuador, Galápagos: Isabela, Volcán Alcedo, outer S-exposed crater rim, $0^{\circ} 12^{\prime} 23^{\prime \prime} \mathrm{S}, 90^{\circ} 47^{\prime} 4^{\prime \prime} \mathrm{W}, 814 \mathrm{~m}$ alt., humid zone, S-exposed, steep basalt cliffs of crater rim with ferns (Pityrograma calomelanos var. calomelanos, Polypodium tridens, Dryopteris palmata, Adiantum concinnum, Blechnum polypodioides) growing in crevices, on rock, 24-Mar-2006, Bungartz, F. 4813 (CDS 28977-holotype; GenBank Accession number nrITS: MT967404).

Description. Thallus rimose to rimose-areolate, areoles mostly flattened, rarely with subsquamulose edges, effuse, but typically delimited by a compact, \pm zoned prothallus; surface pale to lead or olive-gray, smooth, not shiny, in parts with a fine farinose, whitish pruina, lacking vegetative propagules, but the thallus center occasionally \pm nodular from abundant apothecial initials. Apothecia numerous, often closely adjoining and \pm deforming one another, sessile, basally \pm constricted, up to $1 \mathrm{~mm}$ in diam., biatorine (to indistinctly 'zeorine'); proper margin persistent, prominent, thick, $\sim 160 \mu \mathrm{m}$ wide, dark orange to ferruginous ('rust-colored'), epruinose or \pm covered by the same pruina as the disc, thalline margin absent or extremely thin, gray, \pm concolorous with the thallus or pale yellow (particularly the immature, nodulose apothecial initials); disc plane to eventually slightly concave, concolorous with the proper margin, densely covered by a coarse rusty orange-red, $\mathrm{C}+$ deep red, $\mathrm{K}+$ purple pruina; epihymenium orange brown, with both a diffuse orange-brown pigment, as well as orange pigment granules, $\mathrm{C}+\mathrm{red}, \mathrm{K}+$ purple, contiguous with the outer exciple; hymenium hyaline, not inspersed; proper exciple lacking crystals, differentiated into a broad hyaline inner part, and an orange-brown outer part, brown pigmentation diffuse, orange pigment granules $\mathrm{C}+$ red, $\mathrm{K}+$ purple; subhymenium and hypothecium not differentiated, hyaline, not inspersed; asci clavate, Teloschistes-type; ascospores 8/ascus, polaribilocular, oblong to ellipsoid (8.9-)10.6-13.1(-15.4) × (6.0-)6.4-7.7(-8.3) $\mu \mathrm{m}$, with a thick, (3.4-)3.9-5.6(-7.0) $\mu \mathrm{m}$ wide septum $(\mathrm{n}=45)$. Pycnidia unknown.

Chemistry. Thallus $\mathrm{P}-, \mathrm{K}-, \mathrm{C}-, \mathrm{KC}-, \mathrm{UV}-$ (dull); apothecia $\mathrm{P}-, \mathrm{K}+$ purple, $\mathrm{C}+$ red, $\mathrm{KC}+$ purple to \pm reddish, UV- (dull); no secondary metabolites detected in the thallus, apothecia with equally high proportions of 7-chloroemodin and fragilin, typically present in lower concentrations as accessory are 7-chlorocitreorosein, 7-chloroemodinal and emodin.

Etymology. Named after the Galapagos Islands, where the species is moderately common and possibly endemic.

Ecology and distribution. Known only from the Galapagos, where it grows on sunny to semi-shaded, windand rain-exposed rock, mostly in the upper transition and humid zone, occasionally also in the dry zone and rarely near the coast.

Note. This taxon is very uniform concerning its ITS. Genetically, the closest neighbor is the morphologically similar 'Caloplaca' sonorae (here also placed into Lacrima, see below). Wetmore (2007a) reports Lacrima sonorae from southwestern North America (Arizona, Baja California Sur, western Chihuahua, and Sonora); according to the Consortium of North American Lichen Herbaria, specimens have also been found in southern California (USA), but the species remains unknown from outside the Sonoran Region. Lacrima galapagoensis differs by slightly shorter ascospores (10.6-13.1 $\mu \mathrm{m})$ compared with Lacrima sonorae (12.5-15.5 $\mu \mathrm{m})$. ITS sequences are sufficiently distinct to justify separation at the species level. In Galapagos, Lacrima galapagoensis is most closely related to L. epiphora, and L. aphanotripta (Figs 1-2).

Specimens examined from Ecuador, Galápagos. ISABELA, VOLCÁN ALCEDO: upper NNW-exposed slope inside the crater, $0^{\circ} 27^{\prime} 27^{\prime \prime} \mathrm{S}, 91^{\circ} 7^{\prime} 23^{\prime \prime} \mathrm{W}, 1055 \mathrm{~m}$ alt., humid zone, open vegetation with Adianthus concinnum, and 
scattered shrubs of Tournefortia rufo-sericea among basalt rocks, on rock, 05-Mar-2006, Bungartz, F. 4091 (CDS 28055); Aptroot, A. 64892 (CDS 31469); outer SE-exposed slope and crater rim, $0^{\circ} 27^{\prime} 29^{\prime \prime} \mathrm{S}, 91^{\circ} 7^{\prime} 19^{\prime \prime} \mathrm{W}, 1089 \mathrm{~m}$ alt., humid zone, tortoise pasture with scattered trees (Tournefortia rufo-sericea, Zanthoxylum fagara), on rock, 05-Mar-2006, Aptroot, A. 65114 (CDS 31696); at rim of easternmost crater in the highlands, $0^{\circ} 14^{\prime} 20^{\prime \prime} \mathrm{S}, 90^{\circ} 42^{\prime} 45^{\prime \prime} \mathrm{W}, 400 \mathrm{~m}$ alt., transition zone, on rock, 10-May-1971, Pike, L.H. 2111 (L-55203, COLO 255631), 2111 (OSC 53253); $3.5 \mathrm{~km} \mathrm{NW}$ of the western summit, $0^{\circ} 11^{\prime} 0^{\prime \prime} \mathrm{S}$, $90^{\circ} 48^{\prime} 15^{\prime \prime} \mathrm{W}, 500 \mathrm{~m}$ alt., transition zone, Bursera-Zanthoxylum forest on cinder cone, on rock, 17-May-1971, Pike, L.H. ID70-4 (OSC 53248); along the trail from the caseta in La Central to La Bomba (at the coast), cliff $\sim 2.5 \mathrm{~km} \mathrm{NE}$ of the caseta, $0^{\circ} 13^{\prime} 41^{\prime \prime} \mathrm{S}, 90^{\circ} 44^{\prime} 10^{\prime \prime} \mathrm{W}, 533 \mathrm{~m}$ alt., transition zone, SW-exposed basalt cliff with some ferns (Adiantum concinnum, Pityrograma calomelanos var. calomelanos, and Blechnum polypodioides) growing in crevices, on rock, 25-Mar-2006, Bungartz, F. 4861 (CDS 29060); Cerro Gavilan, directly below the summit at the NE-exposed slope, $0^{\circ} 12^{\prime} 19^{\prime \prime} \mathrm{S}, 90^{\circ} 47^{\prime} 6^{\prime \prime} \mathrm{W}, 828 \mathrm{~m}$ alt., humid zone, formerly with scrub or forest, disturbed by former grazing therefore shrubs and trees missing; artificial pampa with Solanum americanum, Portulaca oleraceum, Senna occidentalis, Borreria laevis, and grasses, basalt boulders and outcrops, on rock, 22-Mar-2006, Bungartz, F. 4715 (CDS 28813); summit of Cerro Gavilan, inner N- and NE-exposed crater rim, $0^{\circ} 12^{\prime} 20^{\prime \prime} \mathrm{S}$, $90^{\circ} 47^{\prime} 3^{\prime \prime} \mathrm{W}, 840 \mathrm{~m}$ alt., humid zone, N- and NE-exposed, steep basalt cliffs of crater rim with ferns (Pityrograma calomelanos var. calomelanos, Polypodium tridens, Dryopteris palmata, Adiantum concinnum, Blechnum polypodioides) growing in crevices, on rock, 23-Mar-2006, Aptroot, A. 65743 (CDS 32335); Bungartz, F. 4776 (CDS 28908). SANTA CRUZ: Puerto Ayora, cliff $\mathrm{N}$ of the town, $0^{\circ} 43^{\prime} 59^{\prime \prime} \mathrm{S}, 90^{\circ} 18^{\prime} 45^{\prime \prime} \mathrm{W}, 20 \mathrm{~m}$ alt., dry zone, Bursera woodland, on rock, 11-Feb-2006, Aptroot, A. 63715 (CDS 30270); near Charles Darwin Research Station (CDRS), $0^{\circ} 44^{\prime} 32^{\prime \prime} \mathrm{S}, 90^{\circ} 18^{\prime} 10^{\prime \prime} \mathrm{W}, 1 \mathrm{~m}$ alt., coastal zone, on rock, 10-Feb2006, Aptroot, A. 63688 (CDS 30244); rim of crater to the NW of Media Luna, inland from the NW-coast, $0^{\circ} 43^{\prime} 51^{\prime \prime} \mathrm{S}$, $89^{\circ} 18^{\prime} 55^{\prime \prime} \mathrm{W}, 149 \mathrm{~m}$ alt., transition zone, lower transition zone; basalt cliffs of inner and outer crater rim with scarce vegetation, on rock, 22-Apr-2007, Bungartz, F. 6296 (CDS 34508); trail from Bahía Manzanillo on the N-coast of the island to the highest point, $1^{\circ} 21^{\prime} 40^{\prime \prime} \mathrm{S}, 89^{\circ} 41^{\prime} 56^{\prime \prime} \mathrm{W}, 48 \mathrm{~m}$ alt., dry zone, open scrub of Cordia lutea and Prosopis juliflora with grasses and few trees of Bursera graveolens over weathered lava boulders, on rock, 11-Nov-2010, Bungartz, F. 9098 (CDS 45916). PINTA: along the trail up to the summit from the S-coast, $0^{\circ} 33^{\prime} 46^{\prime \prime} \mathrm{N}$, $90^{\circ} 44^{\prime} 46^{\prime \prime} \mathrm{W}, 174 \mathrm{~m}$ alt., transition zone, old SW-exposed lava
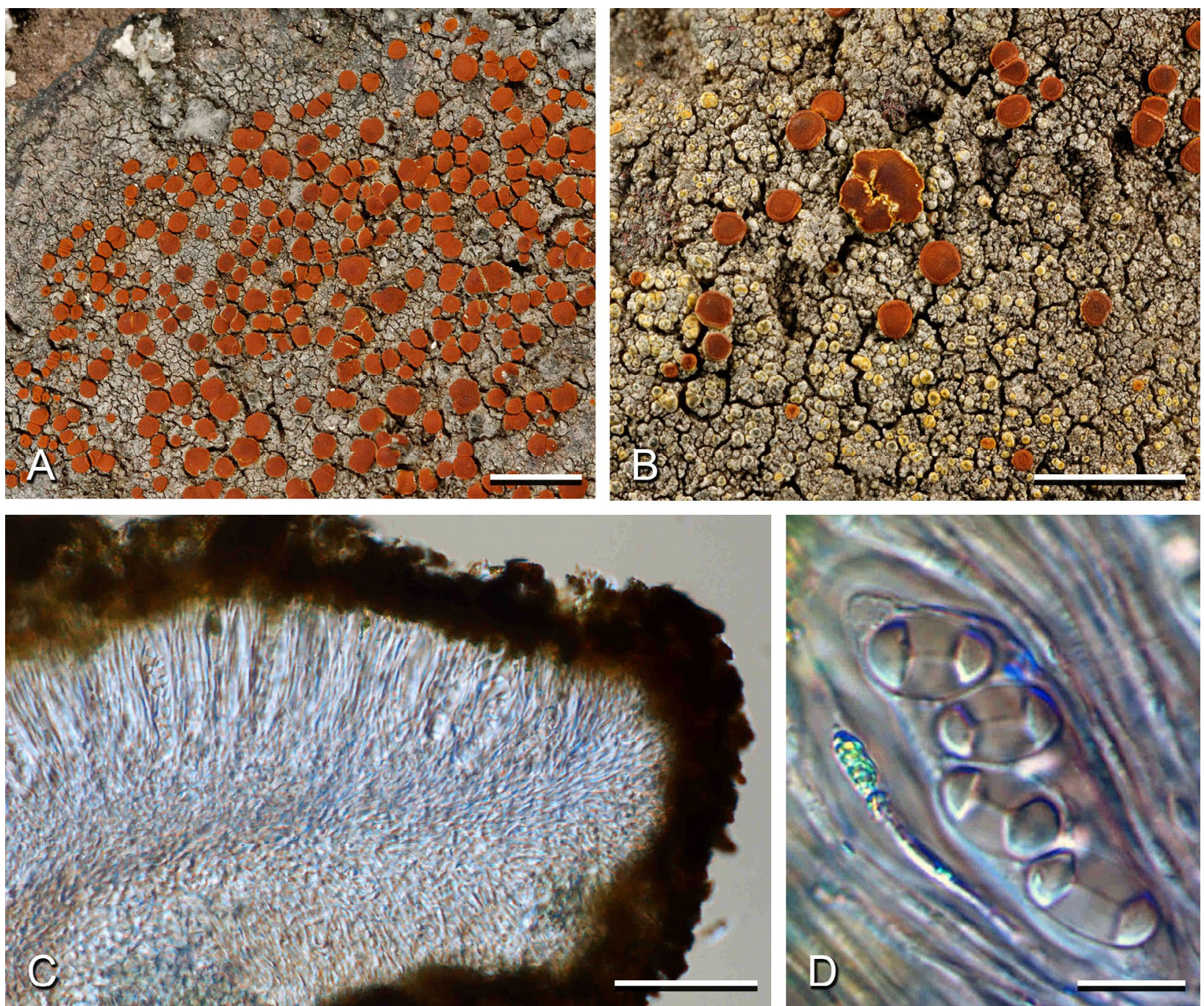

Figure 9. Lacrima galapagoensis. A - gray, rimose areolate thallus with rust-red apothecia, delimited by black prothallus (Bungartz 4715, CDS 28813); B - gray, rimose areolate thallus with pale yellow apothecial initials and rust-red apothecia (Bungartz, F. 4813, CDS 28977-holotype); C - apothecial section: biatorine, outer exciple strongly darkened, deep orange-brown, inner exciple hyaline (Aptroot, A. 63715, CDS 30270); $\mathrm{D}$ - ascus with broadly ellipsoid spores, septum moderately broad [DIC, in water] (Aptroot, A. 63715, CDS 30270). Scales: A-B = 2 mm; $\mathrm{C}=100 \mu \mathrm{m} ; \mathrm{D}=10 \mu \mathrm{m}$. 
flow in open woodland with Bursera graveolens, Croton scouleri, Opuntia galapageia, few Pisonia floribunda, and with Scalesia baurii in the understory, on rock, 28-Feb-2007, Bungartz, F. 5992 (CDS 33670).

\section{New combination of a species of Lacrima not reported from the Galapagos}

Lacrima sonorae (Wetmore) Søchting, Arup \& Bungartz, comb. nov.

MycoBank MB 836942

Basionym: Caloplaca sonorae Wetmore, Bryologist 99(3): 309. 1996; MycoBank MB 436760.

Leproplaca (Nyl.) Nyl., in Hue, Rev. Bot. Bull. Mens. 6: 148. 1888 [1887-88]

MycoBank MB 2756

Leproplaca chrysodeta (Vain.) J.R. Laundon ex Ahti, in Ahti, Kondratyuk, Kärnefelt \& Thell, Graphis Scripta 27(1-2): 39. 2015.

(Figs 1, 12E)

MycoBank MB 811058

Basionym: Placodium chrysodetum Vain., Meddn. Soc. Fauna Flora fenn. 47: 229. 1921; MycoBank MB 369369.

Taxonomic note: Ahti (2015), pointing out that Vainio already published the basionym of this species in 1921, only recently validated the combination $L$. chrysodeta first proposed, but not validly published by Laundon (1974).

Description. Thallus leprose, entirely composed of coarse, deep yellow to orange granules, occasionally in parts \pm brownish orange or grayish yellow; individual granules without protruding hyphae, pseudocorticate, (30-)27-44(-45) $\mu \mathrm{m}$ in diam., either dispersed and isolated, or, when well developed, closely aggregating into a thick crust that secondarily breaks apart and then looks 'areolate'; not delimited by a prothallus, hypothallus absent. Apothecia unknown.

Chemistry. Thallus $\mathrm{P}-, \mathrm{K}+$ purple, $\mathrm{C}-, \mathrm{KC} \pm$ purplish (fading), UV- (dull); with a large proportion of parietin and smaller proportions of teloschistin, fallacinal, parietinic acid and emodin (chemosyndrome A sensu Søchting 1997).

Ecology and distribution. Cosmopolitan; in Galapagos, known from a single specimen only, collected at a shaded, sheltered, W-exposed overhang, in the high-altitude dry zone of Volcán Darwin (Isabela).

Notes. Bungartz et al. (2013) did not include the species in their key to leprose and leproid lichens from the Galapagos. At the time, the only known record was still considered preliminary. DNA extraction from the single known specimen unfortunately failed, but its morphology and secondary chemistry agree well with $L$. chrysodeta, which is presently the only known leprose 'Caloplaca' from the Americas.

Specimens examined from Ecuador, Galápagos. ISABELA, VOLCÁN DARWIN: $\sim 1.5 \mathrm{~km}$ from the southwestern crater rim, $0^{\circ} 12^{\prime} 20^{\prime \prime} \mathrm{S}, 91^{\circ} 18^{\prime} 52^{\prime \prime} \mathrm{W}, 1280 \mathrm{~m}$ alt., high-altitude dry zone, basalt outcrop for the most part bare of vegetation, on rock, 14-Nov-2007, Bungartz, F. 7595 (CDS 38091).

Oceanoplaca Arup, Søchting \& Bungartz, gen. nov.

MycoBank MB 836943

Generic type: Oceanoplaca isidiosa (Vain.) Bungartz, Søchting \& Arup, ibid.

Diagnosis. Thallus saxicolous or corticolous, crustose, granular to subsquamulose or placodioid, often isidiate. Apothecia lecanorine, biatorine or zeorine, asci clavate, of Teloschistes-type, with 8 spores. Ascospores polaribilocular with a moderate to wide septum. Oceanoplaca is phylogenetically well-delimited on a distinct clade in Caloplacoideae with Phaeoplaca as sister genus.

Chemistry. Apothecia and thallus with or without anthraquinones. The anthraquinone isidiosin sometimes present in apothecia and in some species also within the thallus.

Etymology. The genus name is a combination of the syllables '-placa' hinting at Caloplaca (from which species in the genus were transferred), and 'oceano-', indicating a proximity to the sea, i.e., where the species currently known in this genus typically grow.

Known distribution. The genus is so far recorded from the Neotropics (Central America and the Galapagos Islands), the Palaeotropics (Cape Verde Islands), and in North America from the Sonoran Desert Region.

Oceanoplaca chemoisidiosa Søchting \& Bungartz, sp. nov. (Figs 1-2, 10A-C)

MycoBank MB 836945

Diagnosis: A saxicolous species with orange apothecia that, like its sister taxon $O$. isidiosa, contains the anthraquinone isidiosin, the coarsely granular to irregularly subsquamulose thallus lacking secondary metabolites, its surface olive to pale gray, occasionally with isidia.

Type: Ecuador, Galápagos: San Cristóbal, Pan de Azúcar, inland from Bahía Sardinas at the NW-coast of the island, $0^{\circ} 43^{\prime} 6^{\prime \prime} \mathrm{S}, 89^{\circ} 21^{\prime} 19^{\prime \prime} \mathrm{W}, 88 \mathrm{~m}$ alt., dry zone, NE-facing slope near the top of the first small hill with low shrubs of Alternanthera filifolia and few Bursera graveolens trees, on rock, 24Apr-2007, Bungartz, F. 6417 (CDS 34632-holotype; GenBank Accession number nrITS: MT967415).

Description. Thallus coarsely granular to irregularly subsquamulose, of discrete, strongly convex ('bullate'), up to $0.5 \mathrm{~mm}$ broad areoles, effuse, lacking a prothallus or hypothallus; surface olive to pale gray, smooth, but not shiny, dull, with sparse to abundant white pruina (on well-developed specimens entirely masking the gray cortex), occasionally becoming granular isidiate, with scattered, $0.1 \mathrm{~mm}$ thick, \pm coralloid isidia. Apothecia numerous, dispersed, sessile to somewhat stipitate, up to $1.2 \mathrm{~mm}$ in diam., lecanorine; thalline margin prominent, often curved inwards and strongly crenate, flexuose, 0.05-0.06 mm broad, pale orange, color often fading and increasingly whitish to pale orange pruinose towards the outside; disc concave to mostly flat, deep orange, epruinose, $\mathrm{C}-, \mathrm{K}+$ purple; epihymenium with orange pigment 
granules, $\mathrm{C}-( \pm$ orange red intensifying $), \mathrm{K}+$ purple, contiguous with the outer exciple; hymenium hyaline, not inspersed; proper exciple indistinct, almost entirely reduced to a few hyaline hyphae, thalline exciple differentiated into an inner part abundantly filled with small colorless crystals, dissolving in $\mathrm{K}$, obscuring the photobiont cells in between; subhymenium and hypothecium not differentiated, hyaline, not inspersed; asci clavate, Teloschistes-type; ascospores 8/ascus, polaribilocular, oblong to ellipsoid, (9.7-)11.7-15.1(-16.7) × (4.5-)5.3-7.6(-9.5) $\mu \mathrm{m}$, with a thick, (2.7-)3.5-5.4(-6.4) $\mu \mathrm{m}$ wide septum $(\mathrm{n}=43)$. Pycnidia unknown.

Chemistry. Thallus $\mathrm{P}-, \mathrm{K}-, \mathrm{C}-, \mathrm{KC}-, \mathrm{UV}-($ dull); apothecia $\mathrm{P}-, \mathrm{K}+$ purple, $\mathrm{C}-, \mathrm{KC}+$ purplish (fading), UV- (dull); no secondary metabolites detected in the thallus, apothecia with isidiosin.

Etymology. Named for the presence of idiosin, an unusual chemistry that the species shares with Oceanoplaca isidiosa.

Ecology and distribution. Currently known only from Galapagos (Santa Cruz, San Cristóbal, Pinzón), where it is found in the dry zone, on sunny, wind- and rain-exposed rock surfaces.

Note. According to the molecular data (Figs 1-2), Oceanoplaca chemoisidiosa is a sister species of $O$. isidiosa, with which it also shares an identical chemistry. In O. chemoisidiosa, the characteristic isidiosin can, however, only be found in the apothecia; the thallus lacks secondary metabolites. Both species are morphologically distinctly different: Oceanoplaca isidiosa forms placodioid, deep orange to orange-red thalli with well developed, radiating marginal lobes. It is typically abundantly isidiate and often lacks apothecia. Oceanoplaca chemoisidiosa is not placodioid, its thalli are effuse, of irregularly dispersed granular to bullate or even subsquamulose, gray to whitish pruinose areoles. Specimens rarely form isidia, but are typically fertile. The Sonoran Desert species 'Caloplaca' lagunensis Wetmore is morphologically somewhat similar, but the spores are larger $(18-22 \times 10-12.5 \mu \mathrm{m})$ and consistently have three locules. The species also contains lichexanthone instead of isidiosin.

Specimens examined from Ecuador, Galápagos. SANTA CRUZ: at the East coast of the island, cinder cone $\sim 100 \mathrm{~m}$ SW of Cerro Colorado, $0^{\circ} 34^{\prime} 59^{\prime \prime} \mathrm{S}, 90^{\circ} 10^{\prime} 21^{\prime \prime} \mathrm{W}, 11 \mathrm{~m}$ alt., dry zone, bare rock surface of aggregated volcanic ash with scarce vegetation of Scutia spicata var. pauciflora, Acacia rorudiana, Opuntia echios, and rarely Bursera graveolens, on rock, 21-Feb2006, Bungartz, F. 3864 (CDS 27746); Aptroot, A. 64354 (CDS 30919). SAN CRISTÓBAL: Pan de Azúcar, inland from Bahía Sardinas at the NW-coast of the island, $0^{\circ} 43^{\prime} 13^{\prime \prime} \mathrm{S}, 89^{\circ} 21^{\prime} 14^{\prime \prime} \mathrm{W}$, $155 \mathrm{~m}$ alt., dry zone, E- to SE-exposed cliff at E-facing slope of the hill, on rock, 24-Apr-2007, Bungartz, F. 6436 (CDS 34651). PINZÓN: along the trail going up from Playa Escondida, N- to $\mathrm{W}$-facing cliff above a crater, $0^{\circ} 36^{\prime} 30^{\prime \prime} \mathrm{S}, 90^{\circ} 40^{\prime} 12^{\prime \prime} \mathrm{W}, 319 \mathrm{~m}$ alt., dry zone, vertical cliff of weathered basalt lava among dense shrubby vegetation of Croton scouleri, Acacia rorudiana, Prosopis juliflora and Alternanthera filifolia, on rock, 22-Jun2009, Bungartz, F. 8737 (CDS 44419).
Oceanoplaca isidiosa (Vain.) Bungartz, Søchting \& Arup, comb. nov.

(Figs 1-2, 10D-F)

\section{MycoBank MB 836944}

Basionym: Placodium isidiosum Vain., Étud. Class. Lich. Brésil 1: 118. 1890; MycoBank MB 533770.

Description. Thallus placodioid, of convex, \pm elongate-radiating areoles in the center and \pm convex, widening to fan-shaped, $\sim 0.2 \mathrm{~mm}$ broad lobes along the periphery, individual thalli up to $2.5 \mathrm{~cm}$ in diam., but several thalli frequently confluent, merging with one another; hypothallus and prothallus absent; surface strongly yellow orange to deep reddish orange, not shiny, or with a faint, farinose orange, or rarely whitish pruina, particularly in the center densely isidiate; isidia initially \pm papillate to nodular, granular-globose, but soon broadly cylindrical to coarsely coralloid, $0.1-0.2 \mathrm{~mm}$ thick. Apothecia frequently absent or poorly developed, the thallus then densely isidiate; if present, sparse to numerous and interspersed with isidia, not closely grouped, sessile to slightly stipitate, $0.6-0.8(-1) \mathrm{mm}$ in diam., lecanorine; thalline margin thick, $\sim 150 \mu \mathrm{m}$ and prominent, often curved inwards and soon strongly crenate, circular to soon flexuose, strongly yellow orange to deep reddish orange, concolorous with the thallus, epruinose to rarely sparsely whitish pruinose, $\mathrm{C}-, \mathrm{K}+$ purple, proper margin absent or not clearly differentiated; disc deep orange, concolorous or darker than the thallus, initially concave, later flat, epruinose to rarely sparsely whitish pruinose, $\mathrm{C}-, \mathrm{K}+$ purple; epihymenium with orange pigment granules, $\mathrm{C}-$ ( \pm orange red intensifying), $\mathrm{K}+$ purple, contiguous with the outer exciple; hymenium hyaline, not inspersed; proper exciple absent (completely reduced); thalline exciple differentiated into a broad inner part abundantly filled with large trebouxioid photobionts and few, small, colorless crystals, dissolving in $\mathrm{K}$, and an outer part, with orange pigment granules, $\mathrm{C}-$ ( \pm orange red intensifying), $\mathrm{K}+$ purple; subhymenium and hypothecium not differentiated, hyaline, not inspersed; asci clavate, Teloschistes-type; ascospores 8/ascus, polaribilocular, ellipsoid to broadly ellipsoid (8.3-)9.2-11.6(-13.1) $\times$ (4.6-)5.4-7.6(-9.2) $\mu \mathrm{m}$, with a moderately thickened, $(1.9-) 2.4-3.7(-4.3) \mu \mathrm{m}$ wide septum $(\mathrm{n}=34)$. Pycnidia not observed.

Chemistry. Thallus and apothecia $\mathrm{P}-, \mathrm{K}+$ purple, $\mathrm{C}-$, $\mathrm{KC}+$ purplish (fading), UV- (dull); with abundant amounts of isidiosin.

Ecology and distribution. Originally described from Brazil (Vainio 1890) and first reported from Galapagos by Weber (1986). It is a common species on mostly sunny, wind- and rain-exposed rock, less common in \pm sheltered, semi-shaded habitats, especially near the coast, less common throughout the dry and lower transition zone, rarely also into the humid zone.

Notes. Even though $O$. isidiosa is morphologically very variable, fertile specimens with conspicuous whitish pruina covering the marginal lobes, in the center less 
distinctly isidiate, but instead with large, nodular apothecial initials, were initially considered to represent a separate species. This hypothesis was not confirmed by the phylogenetic analyses. ITS sequences of the Galapagos specimens are all very uniform and well separated from its sister $O$. chemoisidiosa, with which the species shares the secondary metabolite isidiosin (for more detail see the description there). Weber originally annotated the pruinose specimens as 'Caloplaca saxicola', but never published these annotations and the name 'Caloplaca saxicola' was never included in his checklist (see list of species that do not occur in Galapagos).

Specimens examined from Ecuador, Galápagos. ISABELA, VOLCÁN ALCEDO: cinder cone $\sim 100 \mathrm{~m}$ from the shore and a little $\mathrm{N}$ of Islote Cowley, $0^{\circ} 22^{\prime} 54^{\prime \prime} \mathrm{S}, 91^{\circ} 0^{\prime} 4^{\prime \prime} \mathrm{W}, 17 \mathrm{~m}$ alt., coastal zone, basalt outcrops (AA lava) bare of vascular plant vegetation, on rock, 11-Mar-2006, Bungartz, F. 4502 (CDS 28588); cinder cones along the trail going up the E-slope, $0^{\circ} 23^{\prime} 40^{\prime \prime} \mathrm{S}, 91^{\circ} 1^{\prime} 18^{\prime \prime} \mathrm{W}, 190 \mathrm{~m}$ alt., dry zone, basalt outcrops, at the bottom scattered Bursera graveolens trees and shrubs of Castela galapageia, on rock, 10-Mar-2006, Aptroot, A. 64719 (CDS 31293). VOLCÁN CERRO AZUL: basalt cliffs south of Caleta Iguana, $0^{\circ} 58^{\prime} 53^{\prime \prime} \mathrm{S}, 91^{\circ} 26^{\prime} 52^{\prime \prime} \mathrm{W}, 8 \mathrm{~m}$ alt., coastal zone, almost vertical cliff faces of moderately young, roughened basalt lava, lacking vascular plant vegetation, on rock, 09-May-2012, Spielmann, A.A. 10739 (CDS 52142), Bungartz, F. 10549 (CDS 52560). VOLCÁN SIERRA NEGRA: Las Tintoreras, small island infront of Puerto Villamil at the S-coast of Isabela, $0^{\circ} 58^{\prime} 13^{\prime \prime} \mathrm{S}, 90^{\circ} 57^{\prime} 39^{\prime \prime} \mathrm{W}, 13 \mathrm{~m}$ alt., coastal zone, young lava flow of AA-lava bare of vegetation, on rock, 10-Sep-2007, Bungartz, F. 7015 (CDS 36522); Cerro Orchilla, 4 km W of Puerto Villamil, $0^{\circ} 57^{\prime} 47^{\prime \prime} \mathrm{S}, 91^{\circ} 0^{\prime} 27^{\prime \prime} \mathrm{W}, 56 \mathrm{~m}$ alt., dry zone, S-exposed slope of hill, open Bursera graveolens forest with Croton scouleri and Opuntia echios, on rock, 17-Aug-2008, Bungartz, F. 8457 (CDS 41103). RÁBIDA: in saddle between cinder cone and main peak, dry zone, on rock, 01-May-1976, Weber, W.A. s.n. (CDS 10872), s.n. (QCA); E-side of the island, dry zone, Bursera forest and lava talus slope, 01-May-1976, Weber, W.A. s.n. (L-62864, COLO 294657). SAN CRISTÓBAL: Cerro Mundo, rock cliffs on the S-side close to the summit, $0^{\circ} 53^{\prime} 32^{\prime \prime} \mathrm{S}$, $89^{\circ} 34^{\prime} 40^{\prime \prime} \mathrm{W}, 253 \mathrm{~m}$ alt., transition zone, with Bursera graveolens, Croton scouleri, Piscidia carthagenensis, Zanthoxylum fagara and a few Scalesia pedunculata, slope $45^{\circ}$ ESE, on rock, 25-Aug-2008, Truong, C. 1539 (CDS 39850); inland from Punta Pit at the NE-coast of the island, $0^{\circ} 43^{\prime} 6^{\prime \prime} \mathrm{S}, 89^{\circ} 14^{\prime} 36^{\prime \prime} \mathrm{W}, 20 \mathrm{~m}$ alt., dry zone, NNW-exposed slope of old lava flow with scarce vegetation, on rock, 20-Apr-2007, Bungartz, F. 6080 (CDS 33759), 6100 (CDS 33779); rim of crater to the NW of Media Luna, inland from the NW-coast, $0^{\circ} 43^{\prime} 51^{\prime \prime} \mathrm{S}, 89^{\circ} 18^{\prime} 55^{\prime \prime} \mathrm{W}, 149 \mathrm{~m}$ alt., transition zone, lower transition zone; basalt cliffs of inner and outer crater rim with scarce vegetation, on rock, 22-Apr2007, Bungartz, F. 6293 (CDS 34505); Cerro Colorado, enclosure for Calandrinia galapagosa near the viewpoint on the top, $0^{\circ} 54^{\prime} 58^{\prime \prime} \mathrm{S}, 89^{\circ} 26^{\prime} 5^{\prime \prime} \mathrm{W}, 130 \mathrm{~m}$ alt., transition zone, open scrubland with Croton scouleri, Macraea laricifolia, Calandrinia galapagosa, Lecocarpus darwinii and few trees of Piscidia carthagenensis among lava boulders on SE-exposed slope of cinder cone, on rock, 29-Apr-2007, Bungartz, F. 6702 (CDS 34946); near Rosa Blanca, at the SE-coast of the island, $0^{\circ} 49^{\prime} 37^{\prime \prime} \mathrm{S}, 89^{\circ} 21^{\prime} 4^{\prime \prime} \mathrm{W}, 3 \mathrm{~m}$ alt., coastal zone, lava cliff at the coast, on rock, 23-Apr-2007, Bungartz, F. 6337 (CDS 34552). SANTIAGO: summit of Cerro Gavilan, outer S-exposed crater rim, $0^{\circ} 12^{\prime} 23^{\prime \prime} \mathrm{S}, 90^{\circ} 46^{\prime} 57^{\prime \prime} \mathrm{W}, 840 \mathrm{~m}$ alt., humid zone, S-exposed, steep basalt cliffs of crater rim with ferns (Pityrograma calo- melanos var. calomelanos, Polypodium tridens, Dryopteris palmata, Adiantum concinnum, Blechnum polypodioides) growing in crevices, on bone, 23-Mar-2006, Aptroot, A. 65644 A(CDS 32234), 65744 (CDS 32336); 7 km inland from the E-coast, \pm at the same latitude as Bahía Sullivan, $0^{\circ} 17^{\prime} 1^{\prime \prime} \mathrm{S}, 90^{\circ} 38^{\prime} 24^{\prime \prime} \mathrm{W}$, 183 m alt., dry zone, SE-exposed slope of lava flow, on rock, 17-Jul-2006, Bungartz, F. 5143 (CDS 29356); small hill 1 km inland from the E-coast, at the same latitude as Bartolomé, $0^{\circ} 17^{\prime} 40^{\prime \prime} \mathrm{S}, 90^{\circ} 35^{\prime} 10^{\prime \prime} \mathrm{W}, 77 \mathrm{~m}$ alt., dry zone, SW-exposed slope of small hill with occasional Bursera graveolens trees and few shrubs (Castela galapageia and Scutia spicata var. pauciflora), on rock, 20-Jul-2006, Bungartz, F. 5281 (CDS 29497); along the trail from Bucanero to Jaboncillos, $3 \mathrm{~km}$ SE of Bucanero, $0^{\circ} 10^{\prime} 52^{\prime \prime} \mathrm{S}, 90^{\circ} 48^{\prime} 33^{\prime \prime} \mathrm{W}, 362 \mathrm{~m}$ alt., transition zone, open woodland of large Bursera graveolens and smaller Psidium galapageium trees, grassland and basalt boulders in between, on rock, 22-Mar-2006, Aptroot, A. 65404 (CDS 31990); Bungartz, F. 4618 (CDS 28705); $\sim 1 \mathrm{~km}$ below the summit, Cerro Gavilan, $0^{\circ} 11^{\prime} 45^{\prime \prime} \mathrm{S}, 90^{\circ} 47^{\prime} 20^{\prime \prime} \mathrm{W}, 680 \mathrm{~m}$ alt., transition zone, open Psidium galapageium forest with Zanthoxylum fagara, Blainvillea dichotoma, Mentzelia aspera and Senna obtusifolia, basalt boulders and outcrops in between, on rock, 22-Mar-2006, Aptroot, A. 65467 (CDS 32056); 5 km inland from the E-coast, \pm at the same latitude as Bahía Sullivan, $0^{\circ} 16^{\prime} 37^{\prime \prime} \mathrm{S}, 90^{\circ} 37^{\prime} 24^{\prime \prime} \mathrm{W}$, $163 \mathrm{~m}$ alt., dry zone, SE-exposed slope of lava boulders, on rock, 18-Jul-2006, Bungartz, F. 5196 (CDS 29409), 5211 (CDS 29424); at the W-coast of the island in Bahía Ladilla, $0^{\circ} 18^{\prime} 8^{\prime \prime} \mathrm{S}$, $90^{\circ} 49^{\prime} 56^{\prime \prime} \mathrm{W}, 10 \mathrm{~m}$ alt., coastal zone, NE-exposed lava cliff and boulders, on rock, 22-Jul-2006, Bungartz, F. 5376 (CDS 29592), 5364 (CDS 29580); red cinder cone E of Pta. Baquerizo, $0^{\circ} 16^{\prime} 15^{\prime \prime} \mathrm{S}, 90^{\circ} 52^{\prime} 0^{\prime \prime} \mathrm{W}, 45 \mathrm{~m}$ alt., dry zone, on rock, 25-Apr1971, Pike, L.H. 2559 (L-55198, COLO 255626), 2559 (OSC 53251). SANTA CRUZ: vicinity of Academy Bay, 15-Feb1964, Weber, W.A. 141-5 (L-40815, COLO 193426), 141-145 (L-40811, COLO 193430), s.n. (L-40831, COLO 193553); $0.8 \mathrm{~km}$ E of Darwin Station, coastal zone, boulders just above high tide mark, on rock, 15-Feb-1964, Weber, W.A. s.n. (L-40041, COLO 186244); top of sea barranca $0.5 \mathrm{mi} \mathrm{E}$ of Darwin Station, coastal zone, on wood, 29-Jan-1964, Weber, W.A. s.n. (L-40073, COLO 185981); barranco near seismic station, $20 \mathrm{~m}$ alt., dry zone, on rock, 12-Apr-1976, Weber, W.A. s.n. (CDS 10822), s.n. (QCA); just E of Darwin Station, coastal zone, on rocks just above high tide mark along S-coast, on rock, 13-Apr-1976, Weber, W.A. s.n. (L-63303, COLO 297118); on rock, Hill, T. s.n. (FH-TUCK 259993); along the S coast of Santa Cruz, $\sim 1.2 \mathrm{~km}$ to the east of the Charles Darwin Research Station (CDRS), Puerto Ayora, $0^{\circ} 44^{\prime} 44^{\prime \prime} \mathrm{S}, 90^{\circ} 17^{\prime} 42^{\prime \prime} \mathrm{W}, 13 \mathrm{~m}$ alt., coastal zone, bare lava rocks with Cryptocarpus pyriformis, Jasminocereus thouarsii, Opuntia echios, and Scutia spicata occasionally in between, on wood, 10-Feb-2006, Aptroot, A. 63704 (CDS 30259); along the S-coast of Santa Cruz close to the Charles Darwin Research Station (CDRS), Puerto Ayora, $0^{\circ} 44^{\prime} 35^{\prime \prime} \mathrm{S}, 90^{\circ} 18^{\prime} 14^{\prime \prime} \mathrm{W}, 1 \mathrm{~m}$ alt., coastal zone, bare lava rocks, Cryptocarpus pyriformis occasionally in between, on rock, 10-Feb-2006, Bungartz, F. 3409 (CDS 27115); Puerto Ayora, near Charles Darwin Research Station (CDRS), $0^{\circ} 44^{\prime} 32^{\prime \prime} \mathrm{S}, 90^{\circ} 18^{\prime} 10^{\prime \prime} \mathrm{W}, 5 \mathrm{~m}$ alt., coastal zone, on rock, 24-May2005, Aptroot, A. 63123 (CDS 29853); Cerro Gallina, $20 \mathrm{~m}$ alt., dry zone, on exposed rock wall near coast, 01-May-1999, Adsersen, H. s.n. (CDS 56120, C); along shore E of Puerto Ayora near Charles Darwin Research Station (CDRS), $0^{\circ} 44^{\prime} 38^{\prime \prime} \mathrm{S}$, $90^{\circ} 18^{\prime} 1^{\prime \prime} \mathrm{W}, 1 \mathrm{~m}$ alt., coastal zone, on rock, 29-May-2005, Aptroot, A. 63262 (CDS 29997). ISLOTE PLAZA NORTE (SANTA CRUZ): $0^{\circ} 34^{\prime} 47^{\prime \prime} \mathrm{S}, 90^{\circ} 9^{\prime} 47^{\prime \prime} \mathrm{W}, 1 \mathrm{~m}$ alt., coastal zone, vertical, S-exposed cliffs and on top of island inpenetrable thicket of Grabowskia boerhaaviaefolia and Scutia spicata 

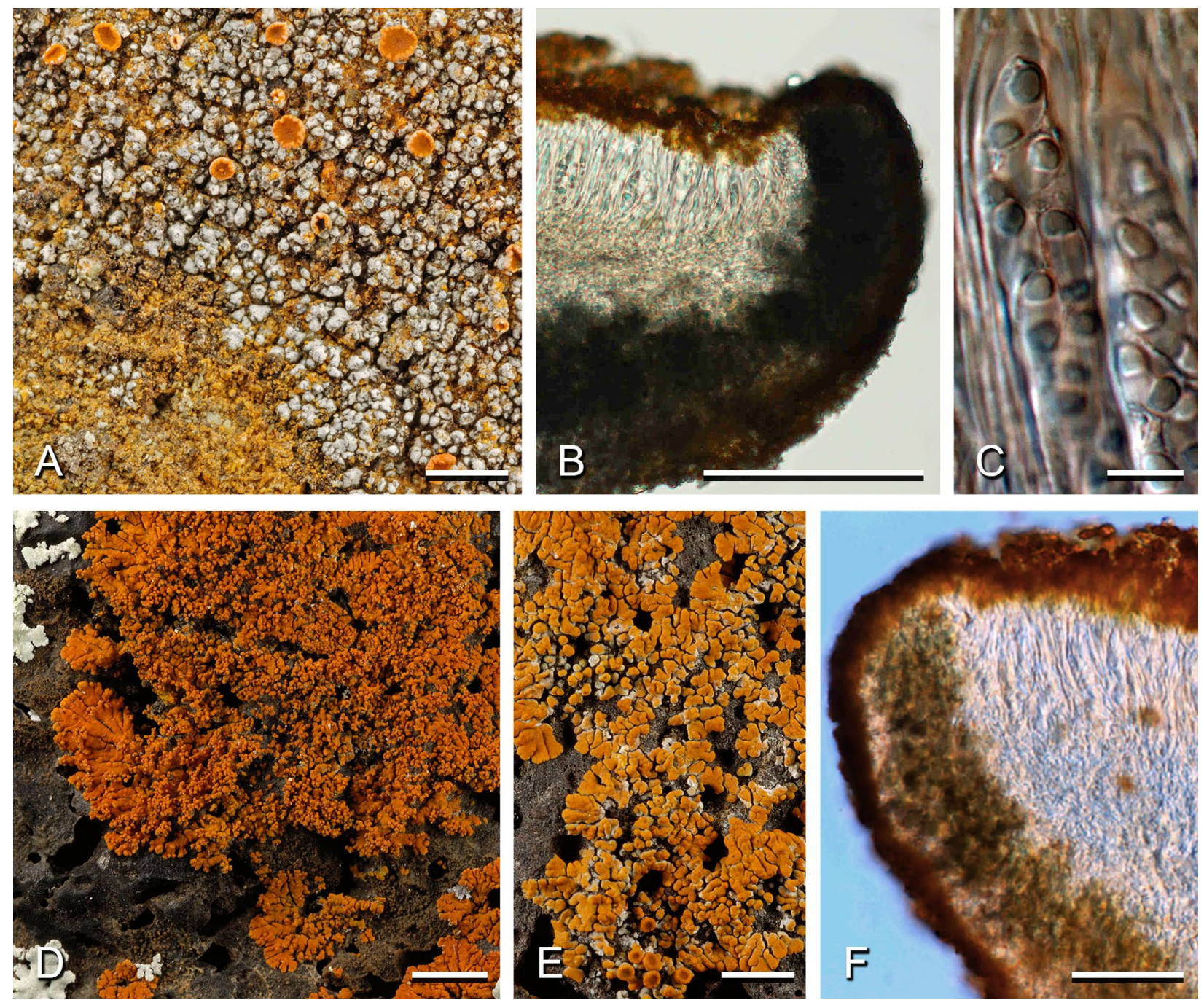

Figure 10. Species of Oceanoplaca with isidiosin. A-C - Oceanoplaca chemoisidiosa. A - pale gray, \pm pruinose bullate-areolate thallus, apothecia orange, sessile, crenate margin paler and more distinctly pruinose than the disc (Bungartz 6417, CDS 34632-holotype); B - apothecial section: lecanorine, outer exciple and epihymenium abundantly filled with orange-brown granules, inner exciple filled with a mixture of small, gray crystals obscuring the green photobiont cells [DIC, in water] (Bungartz 6436, CDS 34651); C - asci with oblong ascospores, septum broad [DIC, in water] (Bungartz 6417, CDS 34632-holotype). D-F - Oceanoplaca isidiosa. D - placodioid-lobate, deep reddish orange, strongly isidiate thallus (Bungartz, F. 5211, CDS 29424); E - placodioid-lobate, strongly yellow orange, sparsely papillate-isidiate thallus (Bungartz, F. 6036, CDS 33715); F - apothecial section: lecanorine, outermost exciple and epihymenium deep orange, inner exciple abundantly filled with trebouxioid green algae [DIC, in water] (Bungartz, F. 5281, CDS 29497). Scales: A, D-E = $2 \mathrm{~mm} ; \mathrm{B}, \mathrm{F}=100 \mu \mathrm{m} ; \mathrm{C}=10 \mu \mathrm{m}$.

var. pauciflora with occasional Opuntias in between, on wood, 21-Feb-2006, Bungartz, F. 3838 (CDS 27720); Aptroot, A. 64401 (CDS 30967); coastal zone, 15-Feb-1964, Weber, W.A. 395 (L-41045, COLO 193087), s.n. (L-40113, COLO 188183). ISLOTE PLAZA SUR (SANTA CRUZ): coastal zone, 13-Feb1964, Weber, W.A. s.n. (L-40113, COLO 189446); 0³4'59"S, $90^{\circ} 9^{\prime} 54^{\prime \prime} \mathrm{W}, 1 \mathrm{~m}$ alt., coastal zone, eastern part with scattered, low vegetation of Sesuvium portulacastrum \& Tiquilia galapagoa with occasional Opuntias, western part also with scattered scrubs of Grabowskia boerhaaviaefolia, Maytenus octogona, and Castela galapageia, on rock, 21-Feb-2006, Bungartz, F. 3753 (CDS 27635); Aptroot, A. 64442 (CDS 31010). ISLOTE PLAZA - UNSPECIFIED (SANTA CRUZ): Las Plazas, on rock, 29-Mar-1971, Higgins, A. s.n. (FH 197427). ISLOTE CAAMAÑO (SANTA CRUZ): 15-Feb-1964, Weber, W.A. 133 (L-40993, COLO 190364). WOLF: Cavagnaro, D. s.n. (L-40914, COLO 190115). PINTA: Dawson, E.Y. s.n. (L-44012, COLO 190196); along the S-coast, $\mathrm{W}$ of Cabo Ibbetson, $0^{\circ} 32^{\prime} 42^{\prime \prime} \mathrm{N}$, $90^{\circ} 44^{\prime} 12^{\prime \prime} \mathrm{W}, 2 \mathrm{~m}$ alt., coastal zone, S-exposed coastal lava cliffs bare of vegetation, on rock, 28-Feb-2007, Bungartz, F. 6036 (CDS 33715). FLOREANA: lava flow near the shore just $\mathrm{N}$ of Black Beach, dry zone, 24-Apr-1976, Weber, W.A. s.n. (L-62979, COLO 294543); SE of Black Beach, 01¹7'17"S, $90^{\circ} 28^{\prime} 58^{\prime \prime} \mathrm{W}, 50 \mathrm{~m}, 2001$, Adsersen, H. s.n. (LAM8, C) (); just S of Black Beach, dry zone, rocky point, on rock, 26-Apr-1976, Weber, W.A. s.n. (L-63014, COLO 291537); between La Gigante and Playa de los Perros, a little inland from coast, E-side of island, $1^{\circ} 17^{\prime} 20^{\prime \prime} \mathrm{S}, 90^{\circ} 21^{\prime} 40^{\prime \prime} \mathrm{W}, 27 \mathrm{~m}$ alt., coastal zone, coastal lava flow bare of vegetation, SE-exposed, on rock, 17-Jan-2011, Bungartz, F. 9824 (CDS 47162); lava flow $200 \mathrm{~m}$ N of village Puerto Velasco Ibarra, at W-coast of the island, directly at the coast, $1^{\circ} 16^{\prime} 9^{\prime \prime} \mathrm{S}, 90^{\circ} 29^{\prime} 20^{\prime \prime} \mathrm{W}, 10 \mathrm{~m}$ alt., coastal zone, lava flow of weathered AA-lava with scarce vegetation, on rock, 18-Jan2011, Bungartz, F. 9895 (CDS 47233); lava flow behind beach ('White Beach') at SE side of Punta Cormorán, 100 m inland, $1^{\circ} 13^{\prime} 44^{\prime \prime} \mathrm{S}, 90^{\circ} 25^{\prime} 27^{\prime \prime} \mathrm{W}, 4 \mathrm{~m}$ alt., coastal zone, lava flow of weathered AA-lava with scarce vegetation of few Bursera trees and Mentzelia aspera, on rock, 19-Jan-2011, Bungartz, F. 9906 (CDS 47244). ISLOTE CAMPÉON (FLOREANA): S-side, bare lava talus, on rock, 23-Apr-1976, Weber, W.A. s.n. (L-62782, COLO 294738). DARWIN: Dawson, E.Y. s.n. (L-40897, COLO 190274); $450 \mathrm{~m}$ alt., Cavagnaro, D. s.n. 
(L-40907, COLO 190354). GENOVESA: edge of new lava flow N of Darwin Bay, dry zone, Smith, A.G. s.n. (L-41146, COLO 193197). ESPAÑOLA: 3 m alt., coastal zone, Cryptocarpus, on rock, 26-Mar-1971, Higgins, A. s.n. (FH 197426); Punta Suárez, $1^{\circ} 22^{\prime} 10^{\prime \prime} \mathrm{S}, 89^{\circ} 44^{\prime} 42^{\prime \prime} \mathrm{W}, 2 \mathrm{~m}$ alt., coastal zone, Cryptocarpus vegetation with lava boulders, on rock, 10-Nov2010, Yánez-Ayabaca, A. 1628 (CDS 45457); Punta Cevallos at E-coast of island, $1^{\circ} 23^{\prime} 38^{\prime \prime} \mathrm{S}, 89^{\circ} 37^{\prime} 8^{\prime \prime} \mathrm{W}, 26 \mathrm{~m}$ alt., coastal zone, basalt cliff almost bare of vegetation, some Ipomoea habeliana, on rock, 09-Nov-2010, Bungartz, F. 8797 (CDS 45615), 8813 (CDS 45631); along S-coast of the island, near Punta Suárez, $1^{\circ} 22^{\prime} 32^{\prime \prime} \mathrm{S}, 89^{\circ} 44^{\prime} 16^{\prime \prime} \mathrm{W}, 26 \mathrm{~m}$ alt., coastal zone, lava cliff almost bare of vegetation, on rock, 10-Nov-2010, Bungartz, F. 8853 (CDS 45671); trail from Bahía Manzanillo on the N-coast of the island to the highest point, $1^{\circ} 22^{\prime} 18^{\prime \prime} \mathrm{S}$, $89^{\circ} 42^{\prime} 7^{\prime \prime} \mathrm{W}, 130 \mathrm{~m}$ alt., dry zone, basalt outcrop among Cordia lutea shrubland, on rock, 11-Nov-2010, Bungartz, F. 9103 (CDS 45921). ISLOTE GARDNER (ESPAÑOLA): SW-part of the island, $1^{\circ} 20^{\prime} 46^{\prime \prime} \mathrm{S}, 89^{\circ} 38^{\prime} 54^{\prime \prime} \mathrm{W}, 7 \mathrm{~m}$ alt., coastal zone, boulder field of weathered AA-lava with the vine Ipomoea habeliana and few shrubs of Bursera graveolens, Prosopis juliflora and Croton scouleri, on rock, 12-Nov-2010, Bungartz, F. 9183 (CDS 46001 ); N-part of the island, on top of the ridge, $1^{\circ} 20^{\prime} 32^{\prime \prime} \mathrm{S}$, $89^{\circ} 38^{\prime} 42^{\prime \prime} \mathrm{W}, 47 \mathrm{~m}$ alt., dry zone, lava cliff with few trees of Bursera graveolens, Croton scouleri shrubs, and the vine Ipomoea habeliana, on rock, 12-Nov-2010, Bungartz, F. 9246 (CDS 46064). BARTOLOMÉ: N-side of island, near Pinnacle Rock, $0^{\circ} 17^{\prime} 2^{\prime \prime} \mathrm{S}, 90^{\circ} 33^{\prime} 15^{\prime \prime} \mathrm{W}, 10 \mathrm{~m}$ alt., coastal zone, W-exposed steep slope of lava flow (basalt) with scarce low vegetation, on rock, 21-Jul-2006, Bungartz, F. 5316 (CDS 29532), 5320 (CDS 29536). PINZÓN: along the trail going up from Playa Escondida, $0^{\circ} 36^{\prime} 10^{\prime \prime} \mathrm{S}, 90^{\circ} 40^{\prime} 1^{\prime \prime} \mathrm{W}, 254 \mathrm{~m}$ alt., dry zone, dry zone vegetation with Prosopis juliflora, Alternanthera filifolia, Maytenus octogona, and Croton scouleri, on rock, 16-Feb-2006, Aptroot, A. 64107 (CDS 30668). SANTA FÉ: top of steep lava cliff above the sea, $0^{\circ} 47^{\prime} 59^{\prime \prime} \mathrm{S}, 90^{\circ} 2^{\prime} 39^{\prime \prime} \mathrm{W}, 16 \mathrm{~m}$ alt., coastal zone, scarce vegetation of Croton scouleri, Opuntia echios var. barringtonensis and few Scalesia helleri shrubs, on rock, 25-Oct-2007, Ertz, D. 11692 (CDS 37018), 7281 (CDS 37765); on top of lava flow at the N-coast of the island, $0^{\circ} 48^{\prime} 12^{\prime \prime} \mathrm{S}$, $90^{\circ} 2^{\prime} 34^{\prime \prime} \mathrm{W}, 13 \mathrm{~m}$ alt., coastal zone, open scrubland of partly dead shrubs (Croton scouleri, Cordia lutea), few shrubby Bursera graveolens, and Opuntia echios var. barringtonensis among lava rocks, on rock, 25-Oct-2007, Bungartz, F. 7246 (CDS 37730), 7251 (CDS 37735); cerca la playita y el barranco en la costa norte de la isla, $0^{\circ} 48^{\prime} 12^{\prime \prime} \mathrm{S}, 90^{\circ} 2^{\prime} 35^{\prime \prime} \mathrm{W}, 26 \mathrm{~m}$ alt., zona seca, bosque abierto con arbustos y árboles dominantes en la zona como: Bursera graveolens y Opuntia echios var. barringtonensis, sobre roca, 25-Oct-2007, Nugra, F. 489 (CDS 37050).

Oceanoplaca sideritoides Søchting \& Bungartz, sp. nov. [Figs 12, 11A-C (morphotype lacking isidia), 11D-F (isidiate morphotype)]

\section{MycoBank MB 836946}

Diagnosis: A saxicolous species with deep orange to ferruginous red apothecial discs lined by a thin, concolorous rim and a pale to deep olive thalline margin on an areolate to irregularly subsquamulose deep olive, sometimes abundantly isidiate thallus; clearly distinguished from Caloplaca sideritis, if the thalli produce isidia, but even specimens lacking vegetative propagules are phylogenetically distinct by their different ITS.

Type: Ecuador, Galápagos: San Cristóbal, SE-exposed slope of Cerro Tortuga, $\sim 4.5 \mathrm{~km}$ inland from the NW-coast, $0^{\circ} 44^{\prime} 55^{\prime \prime} \mathrm{S}$, $89^{\circ} 23^{\prime} 33^{\prime \prime} \mathrm{W}, 110 \mathrm{~m}$ alt., dry zone, open Piscidia carthagenensis woodland with few Bursera graveolens and dense understory of Croton scouleri, Cordia lutea, and Mentzelia aspera on rocky SE-exposed slope of hill, on rock, 25-Apr-2007, Bungartz, F. 6516 (CDS 34733-holotype; GenBank Accession number nrITS: MT967427).

Description. Thallus areolate to irregularly subsquamulose, of discrete, \pm convex, up to $0.4 \mathrm{~mm}$ broad areoles, effuse, with a blackish hypothallus between the areoles, but often confluent and not forming a distinct prothallus along the periphery; two morphotypes: (1) surface pale to deep olive, lacking isidia, smooth and \pm shiny, areoles \pm lined black along their edges, epruinose or irregularly covered in a faint, farinose, white pruina (2) surface completely obscured, densely isidiate, isidia granular, $60-80 \mu \mathrm{m}$ in diam., pale to deep olive, \pm dull, typically not shiny, epruinose or irregularly covered in a faint, farinose, white pruina. Apothecia sparse, sessile, 0.6-0.9 mm in diam., dispersed in between the isidia or isolated among non-isidiate areoles; 'zeorine' to almost biatorine, thalline margin dark olive to almost black, soon excluded by being pushed below, proper margin 50-60(-80) $\mu \mathrm{m}$, increasingly prominent, regularly circular, darkened towards the outside, forming a deep orange rim inside, towards the disc, epruinose to coarsely whitish pruinose, $\mathrm{C}-, \mathrm{K}-$; disc concave to plane, deep orange to ferruginous red, darker than the margin; with indistinct pruina, $\mathrm{C}-$, $\mathrm{K}+$ purple; epihymenium with both pigment granules and diffuse pigmentation, the orange granules not extending into the outer exciple, $\mathrm{C}-$ ( \pm orange red intensifying), $\mathrm{K}+$ purple, the diffuse brownish black to violaceous pigmentation contiguous with the outer exciple, $\mathrm{C}+$ yellowish brown, $\mathrm{K}-$; proper exciple soon dominant, differentiated into an inner, hyaline part, lacking crystals, and an outer brownish black to deeply violaceous part, the pigmentation diffuse, lacking pigment granules, $\mathrm{C}+$ yellowish brown, $\mathrm{K}-$; thalline exciple initially developed along the outside, soon pushed below, excluded, the central part densely filled with trebouxioid photobionts and small crystals that dissolve in $\mathrm{K}$, the outside brownish black to deeply violaceous and contiguous with the proper exciple, the pigmentation diffuse, lacking pigment granules, $\mathrm{C}+$ yellowish brown, $\mathrm{K}-$; subhymenium and hypothecium not differentiated, hyaline, not inspers; asci clavate, Teloschistes-type; ascospores 8/ascus, polaribilocular, broadly ellipsoid to almost globose, spore dimensions of the isidiate morphotype (8.6-)9.3-12.8(-15.2) × (5.6-)6.3$8.0(8.8) \mu \mathrm{m}$, with a thick, $(2.4-) 3.0-4.7(-7.3) \mu \mathrm{m}$ wide septum $(\mathrm{n}=48)$, spore dimensions of the non-isidiate morphotype (5.7-)8.8-12.1(-13.5) × (5.5-)6.3-8.4(-9.8) $\mu \mathrm{m}$, with a thick, $(2.3-) 3.1-4.7(-5.5) \mu \mathrm{m}$ wide septum $(\mathrm{n}=40)$. Pycnidia unknown.

Chemistry. Thallus $\mathrm{P}-, \mathrm{K}-, \mathrm{C}-, \mathrm{KC}-, \mathrm{UV}-($ dull), apothecia $\mathrm{P}-, \mathrm{K}+$ purple, $\mathrm{C}-, \mathrm{KC}-, \mathrm{UV}-($ dull); no secondary metabolites detected in the thallus; apothecia with dominant proportion of parietin and smaller proportions of teloschistin, fallacinal, parietinic acid and emodin. This corresponds to chemosyndrome A sensu Søchting (1997), but additionally smaller proportions 
of chlorinated anthraquinones like fragilin, 7-chloroemodin and 5-chloroemodin have been detected in some specimens.

Etymology. Named for its superficial similarity to the North American C. sideritis.

Ecology and distribution. Known only from the Galapagos. Both morphotypes are saxicolous, the isidiate one is less common; generally found in shaded and \pm sheltered as well as sunny, wind- and rain-exposed habitats, from the coastal zone throughout the dry into the lower transition zone.

Notes. The two different morphotypes were originally considered two different species (see list of excluded taxa below). Although there is some variation in ITS sequence data, the sequences form a well-supported clade and a separation of the two morphotypes as separate species is not supported.

Specimens examined from Ecuador, Galápagos. ISABELA, VOLCÁN ALCEDO: along the trail going up the E-slope, basalt rubble field to the SE-side of the trail and the barranco, $0^{\circ} 24^{\prime} 6^{\prime \prime} \mathrm{S}, 91^{\circ} 2^{\prime} 53^{\prime \prime} \mathrm{W}, 530 \mathrm{~m}$ alt., dry zone, basalt rubble field with scattered vegetation (Bursera graveolens, Zanthoxylum fagara, Pisonia floribunda, Senna pistaciifolia), on rock, 10-Mar-2006, Aptroot, A. 64948 (CDS 31527); along the trail going up the E-slope, basalt rubble field to the SE-side of the trail and the barranco, $0^{\circ} 24^{\prime} 7^{\prime \prime} \mathrm{S}, 91^{\circ} 2^{\prime} 55^{\prime \prime} \mathrm{W}, 493 \mathrm{~m}$ alt., dry zone, basalt rubble field with scattered vegetation (Bursera graveolens, Zanthoxylum fagara, Pisonia floribunda, Senna pistaciifolia), on rock, 10-Mar-2006, Bungartz, F. 4457 (CDS 28543). VOLCÁN DARWIN: southwestern slope, above Tagus Cove, $0^{\circ} 13^{\prime} 27^{\prime \prime} \mathrm{S}$, $91^{\circ} 19^{\prime} 21^{\prime \prime} \mathrm{W}, 860 \mathrm{~m}$ alt., transition zone, open scrubland of Dodonaea viscosa, Croton scouleri, Macraea laricifolia, Scalesia microcephala, few Opuntia insularis and dry grasses in
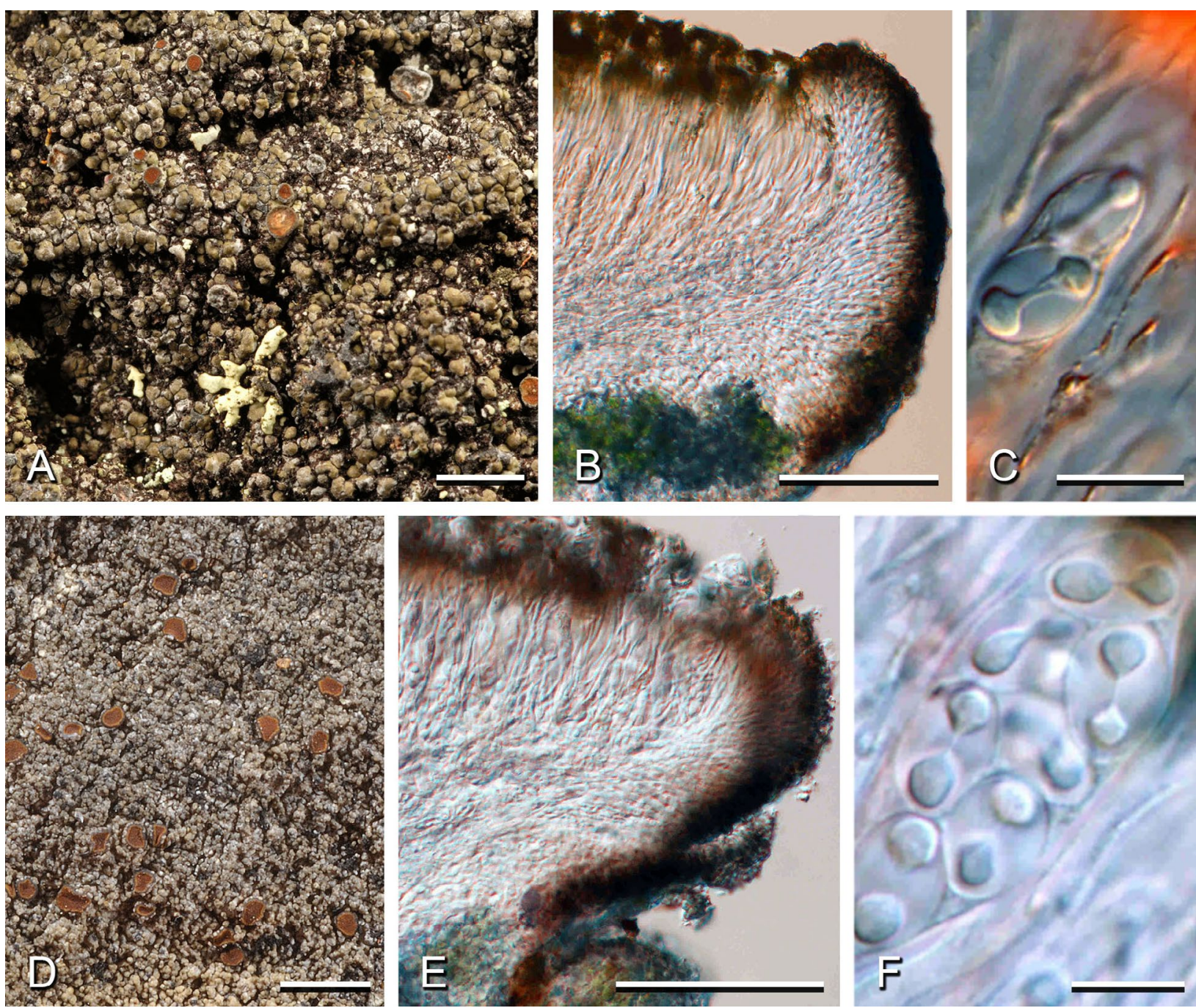

Figure 11. Oceanoplaca sideritoides. A-C - morphotype of Oceanoplaca sideritoides lacking isidia. A - thallus of olive, convex areoles, apothecia sessile, with rust-red disc (Bungartz, F. 4457, CDS 28543); B - apothecial section: zeorine, the proper exciple prominent, hyaline inside, the thalline exciple developed below, abundantly filled with small crystals and trebouxioid green algae, both contiguous along their outside with a deeply violaceous pigment, epihymenium distinct, with brownish pigment granules [DIC, in water] (Bungartz, F. 3663, CDS 27481); C - ascus with broadly ellipsoid spores, septum moderately broad [DIC, in water] (Aptroot, A. 64095, CDS 30656). D-F - morphotype of Oceanoplaca sideritoides with isidia. D - thallus with apothecia and isidia (Bungartz, F. 6516, CDS 34733-holotype); E - apothecial section: zeorine, the proper exciple prominent, hyaline inside, the thalline exciple developed below, abundantly filled with small crystals and trebouxioid green algae, both contiguous along their outside with a deeply violaceous pigment, epihymenium distinct, with brownish pigment granules [DIC, in water] (Bungartz, F. 6516, CDS 34733-holotype); F - ascus with broadly ellipsoid spores, septum moderately broad [DIC, in water] (Aptroot, A. 63686, CDS 30242). Scales: A, D $=2 \mathrm{~mm} ; \mathrm{B}, \mathrm{E}=100 \mu \mathrm{m} ; \mathrm{C}, \mathrm{F}=10 \mu \mathrm{m}$. 
the understory, on rock, 15-Nov-2007, Ertz, D. 11941 (CDS 37300), 11940 (CDS 37299). PINZÓN: E-facing side of a valley on the W-slope of the highest mountain, $0^{\circ} 36^{\prime} 49^{\prime \prime} \mathrm{S}, 90^{\circ} 40^{\prime} 14^{\prime \prime} \mathrm{W}$, $294 \mathrm{~m}$ alt., transition zone, dry transition zone with E-facing basalt cliff and Scalesia baurii ssp. baurii; Polypodium tridens growing on the basalt cliff, on rock, 16-Feb-2006, Bungartz, F. 3597 (CDS 27415); in the valley on the W-slope of the highest mountain, $0^{\circ} 36^{\prime} 41^{\prime \prime} \mathrm{S}, 90^{\circ} 40^{\prime} 11^{\prime \prime} \mathrm{W}, 310 \mathrm{~m}$ alt., dry zone, dry zone vegetation with Prosopis juliflora, Alternanthera filifolia, Maytenus octogona, and Croton scouleri, on rock, 16-Feb-2006, Aptroot, A. 64095 (CDS 30656); along the trail going up from Playa Escondida, N- to W-facing cliff above a crater, $0^{\circ} 36^{\prime} 29^{\prime \prime} \mathrm{S}$, $90^{\circ} 40^{\prime} 14^{\prime \prime} \mathrm{W}, 318 \mathrm{~m}$ alt., transition zone, dry transition zone with Cordia lutea, Croton scouleri, and at the bottom of the cliff also Scalesia baurii ssp. baurii, on rock, 16-Feb-2006, Bungartz, F. 3663 (CDS 27481); along the trail up to the summit from the S-coast, $0^{\circ} 34^{\prime} 3^{\prime \prime} \mathrm{N}, 90^{\circ} 44^{\prime} 56^{\prime \prime} \mathrm{W}, 233 \mathrm{~m}$ alt., transition zone, open woodland with Bursera graveolens, Zanthoxylum fagara, Pisonia floribunda, Croton scouleri, and few Opuntia galapageia among old lava flows; in between Alternanthera filifolia and grasses, on rock, 28-Feb-2007, Bungartz, F. 5960 (CDS 33638), 5969 (CDS 33647). SANTA CRUZ: on the North side of the island, along the dirt road to the ash quarry Mina Granillo Rojo, $0^{\circ} 36^{\prime} 56^{\prime \prime} \mathrm{S}, 90^{\circ} 22^{\prime} 3^{\prime \prime} \mathrm{W}, 570 \mathrm{~m}$ alt., transition zone, lower transition zone; dry semi-deciduous forest with Bursera graveolens and Zanthoxylum fagara, on rock, 23-Feb2006, Bungartz, F. 3883 (CDS 27765); Aptroot, A. 64545 (CDS 31117); above the quarry Mina Granillo Rojo, off the main road to the channel, on the N-side of the island, $0^{\circ} 37^{\prime} 5.798^{\prime \prime} \mathrm{S}$, $90^{\circ} 21^{\prime} 59^{\prime \prime} \mathrm{W}, 617 \mathrm{~m}$ alt., transition zone, open and dry forest of mainly Psidium galapageium, with some Scalesia pedunculata and Pisonia floribunda, and basalt outcrops, on rock, 21-Oct-2007, Bungartz, F. 7128 (CDS 37613). SAN CRISTÓBAL: Cerro Mundo, rock cliffs on the S side close to the summit, $0^{\circ} 53^{\prime} 32^{\prime \prime} \mathrm{S}, 89^{\circ} 34^{\prime} 40^{\prime \prime} \mathrm{W}, 253 \mathrm{~m}$ alt., transition zone, with Bursera graveolens, Croton scouleri, Piscidia carthagenensis, Zanthoxylum fagara and a few Scalesia pedunculata, slope $45^{\circ}$ ESE, on rock, 25-Aug-2008, Truong, C. 1541 (CDS 39852); enclosure for Calandrinia galapagosa near the viewpoint on the top, $0^{\circ} 54^{\prime} 58^{\prime \prime} \mathrm{S}, 89^{\circ} 26^{\prime} 5^{\prime \prime} \mathrm{W}, 130 \mathrm{~m}$ alt., transition zone, open scrubland with Croton scouleri, Macraea laricifolia, Calandrinia galapagosa, Lecocarpus darwinii and few trees of Piscidia carthagenensis among lava boulders on SE-exposed slope of cinder cone, on rock, 29-Apr-2007, Bungartz, F. 6699 (CDS 34943). FLOREANA: trail going to Post Office Bay off the dirt road between highlands and Puerto Velasco Ibarra, cliff at NE-side of trail (Mirador), $1^{\circ} 17^{\prime} 4.298^{\prime \prime} \mathrm{S}, 90^{\circ} 26^{\prime} 36^{\prime \prime} \mathrm{W}$, $365 \mathrm{~m}$ alt., transition zone, $\sim 10 \mathrm{~m}$ high lava cliff within dense scrub of Clerodendrum molle, Croton scouleri and Macraea laricifolia, one single Acacia rorudiana on top of cliff, on rock, 25-Jan-2011, Bungartz, F. 10223 (CDS 47642).

Specimens examined with isidia from Ecuador, Galápagos. ISABELA, VOLCÁN SIERRA NEGRA: Cerro Orchilla, $\sim 4 \mathrm{~km} \mathrm{~W}$ of Puerto Villamil, $0^{\circ} 57^{\prime} 47^{\prime \prime} \mathrm{S}, 91^{\circ} 0^{\prime} 27^{\prime \prime} \mathrm{W}, 56 \mathrm{~m}$ alt., dry zone, S exposed slope of hill, open Bursera graveolens forest with Croton scouleri and Opuntia echios, on rock, 17-Aug2008, Bungartz, F. 8459 (CDS 41105). SANTA CRUZ: vicinity of Academy Bay, on rock, 15-Feb-1964, Weber, W.A. 141-5 (L-40817, COLO 192463), s.n. (L-40828, COLO 190226), s.n. (L-40827, COLO 190227); Puerto Ayora, near Charles Darwin Research Station (CDRS), 0 44'32"S, 90¹8'10"W, $10 \mathrm{~m}$ alt., coastal zone, coastal lava flow, on rock, 10-Feb-2006, Aptroot, A. 63686 (CDS 30242); along shore E of Puerto Ayora near Charles Darwin Research Station (CDRS), $0^{\circ} 44^{\prime} 38^{\prime \prime} \mathrm{S}$, $90^{\circ} 18^{\prime} 1^{\prime \prime} \mathrm{W}, 1 \mathrm{~m}$ alt., coastal zone, on rock, 29-May-2005, Aptroot, A. 63268 (CDS 30004).

\section{New combinations of Oceanoplaca species not reported from the Galapagos}

Oceanoplaca caesioisidiata (Arup \& van den Boom) Arup, comb. nov.

MycoBank MB 836947

Basionym: Caloplaca caesioisidiata Arup \& van den Boom, Biblthca Lichenol. 106: 2. 2011; MycoBank MB 569754.

Oceanoplaca caesiosorediata (Arup \& van den Boom) Arup, comb. nov.

\section{MycoBank MB 836948}

Basionym: Caloplaca caesiosorediata Arup \& van den Boom, Biblthca Lichenol. 106: 3. 2011; MycoBank MB 569755.

Oceanoplaca catillarioides (Arup \& van den Boom) Arup, comb. nov.

\section{MycoBank MB 836949}

Basionym: Caloplaca catillarioides Arup \& van den Boom, Biblthca Lichenol. 106: 4. 2011; MycoBank MB 569756.

Phaeoplaca Søchting, Arup \& Bungartz, gen. nov.

MycoBank MB 836950

Generic type: Phaeoplaca camptidia (Tuck.) Søchting, Arup \& Bungartz, ibid.

Diagnosis. Thallus corticolous, crustose, rimose. Apothecia biatorine, brown, asci clavate, of Teloschistes-type, with 8 spores. Ascospores polaribilocular with wide septum. Phaeoplaca is phylogenetically well delimited on a distinct clade in Caloplacoideae with Oceanoplaca as sister genus.

Chemistry. Anthraquinones absent.

Etymology. The genus name is a combination of the syllables '-placa' hinting at Caloplaca (from which species in the genus were transferred), and the Latin '-phaeo' meaning 'gray', referring to the overall dull color of thallus and apothecia, both lacking the typically bright anthraquinones of most other members of the Teloschistaceae.

Known distribution. The genus is so far recorded from Australia, southeastern USA, Mexico, and the Galapagos Islands.

Phaeoplaca tortuca Søchting \& Bungartz, sp. nov.

(Figs 1-2, 12A-D)

MycoBank MB 836952

Diagnosis: A corticolous species, distinguished from the morphologically extremely similar Phaeoplaca camptidia by its different ITS sequence.

Type: Ecuador, Galápagos: Pinzón, along the trail going up from Playa Escondida, $0^{\circ} 36^{\prime} 10^{\prime \prime} \mathrm{S}, 90^{\circ} 40^{\prime} 1^{\prime \prime} \mathrm{W}, 254 \mathrm{~m}$ alt., dry zone, vegetation with Prosopis juliflora, Alternanthera filifolia, Maytenus octogona, and Croton scouleri, on wood, 16Feb-2006, Bungartz, F. 3644 (CDS 27462-holotype GenBank Accession number nrITS: MT967435).

Description. Thallus an irregular, thin, waxy, continuous to rimose crust, often partially embedded in the substrate, effuse, but typically delimited by an indistinct or 
conspicuous black prothallus; surface pale creamy white to beige, smooth, not shiny, epruinose, lacking vegetative propagules. Apothecia numerous, dispersed or occasionally closely aggregated and \pm deforming one another, soon sessile, $0.3-0.5 \mathrm{~mm}$ in diam., biatorine, proper margin thick, smooth, circular to \pm deformed, pale creamy white to beige to deep brown, epruinose, disc deep brown to blackish brown, weakly whitish pruinose, disc and margin $\mathrm{K}-, \mathrm{C}-$; epihymenium brown, pigmentation diffuse, $\mathrm{K}-$, $\mathrm{C}-$ (bleaching), occasionally in parts with few clusters of $\mathrm{K}+$ purple, $\mathrm{C}+$ red pigment granules, contiguous with the outer exciple; hymenium hyaline, not inspersed; proper exciple differentiated into a hyaline inner part, lacking crystals, extending laterally from the colorless hypothecium below, and a thick, deep brown outer part, $\mathrm{K}-$, $\mathrm{C}-$ (bleaching), occasionally in parts with few clusters of $\mathrm{K}+$ purple, $\mathrm{C}+$ red pigment granules; subhymenium and hypothecium poorly differentiated, hyaline, not inspersed; asci clavate, Teloschistes-type, ascospores 8/ ascus, polaribilocular, ellipsoid to moderately citriform, $(5.9-) 8.6-14.6(-16.0) \times(3.9-) 5.3-8.0(-10.0) \mu \mathrm{m}$, with a broad, (1.5-)3.1-6.0(-8.0) $\mu$ m wide septum $(\mathrm{n}=35)$. Pycnidia unknown.

Chemistry. Thallus and apothecia $\mathrm{P}-, \mathrm{K}-, \mathrm{C}-, \mathrm{KC}-, \mathrm{UV}-$ (dull); no extractable secondary metabolites detected.

Etymology. The epithet is intended as a noun in apposition to the genus name; it refers to the giant tortoises that inhabit the Galapagos archipelago. The name 'tortuca' itself is derived from a medieval poem about tortoises by Jacob van Maerlant in Der naturen bloeme, acclaimed as one of the first encyclopedic treatises of natural history in the Dutch language. We accordingly chose this name in honor of the Dutch lichenologist André Aptroot for his encyclopedic knowledge of lichens and his significant contribution to investigating Galapagos lichen species.

Ecology and distribution. Known only from the Galapagos. Prior to its description as a new species, specimens abundantly found in Galapagos were previously considered to belong to Caloplaca camptidia (Weber 1986, Elix $\&$ McCarthy 1998). It frequently grows on decorticated wood, but also on bark of Bursera graveolens, Scalesia pedunculata and Piscidia carthagenensis, in exposed or \pm sheltered habitats, moderately common in the dry and lower transition, rarely also in the humid zone.

Notes. Phaeoplaca tortuca belongs into the siderites-group. The species was originally reported from the Galapagos by Weber (1986) as C. camptidia, based on several specimens identified by C. M. Wetmore (e.g., Pike, L.H. 2117, L-55205, COLO 255633). The two species are virtually indistinguishable and phylogenetically closely related, but according to their ITS and mrSSU sequences nevertheless well separated (Fig. 1).

Specimens examined from Ecuador, Galápagos. ISABELA, VOLCÁN ALCEDO: on the crater rim near the hut, $0^{\circ} 26^{\prime} 33^{\prime \prime} \mathrm{S}$, $91^{\circ} 5^{\prime} 31^{\prime \prime} \mathrm{W}, 1100 \mathrm{~m}$ alt., humid zone, Pteridium arachnoideum and Stachytarpheta cayennensis, scattered low shrubs of Tournefortia rufo-sericea and outcrops of basalt tuff in between, on wood, 07-Mar-2006, Aptroot, A. 65189 A (CDS 31773). SANTA CRUZ: along the road to Baltra, S of Los Gemelos, $0^{\circ} 38^{\prime} 43^{\prime \prime} \mathrm{S}, 90^{\circ} 20^{\prime} 4.798^{\prime \prime} \mathrm{W}, 741 \mathrm{~m}$ alt., humid zone, Scalesia pedunculata forest with undergrowth of scattered Chiococca alba and abundant ground cover (Valeriana chaerophylloides, Diodia radula and ferns), on bark, 30-Nov-2006, Bungartz, F. 5512 (CDS 32853); Steve Divine's Farm at the end of Tortoise Road, off the main road to Baltra, Tortoise Territory, $0^{\circ} 40^{\prime} 8^{\prime \prime} \mathrm{S}$, $90^{\circ} 24^{\prime} 17^{\prime \prime} \mathrm{W}, 364 \mathrm{~m}$ alt., humid zone, agricultural area, open farmland with Cedrela odorata, Persea americana, Citrus sp., on wood, 23-Feb-2006, Bungartz, F. 3963 (CDS 27845); along the dirt road from Bellavista to Media Luna, farmland on the W-side of the dirt road, $0^{\circ} 40^{\prime} 54^{\prime \prime} \mathrm{S}, 90^{\circ} 19^{\prime} 26^{\prime \prime} \mathrm{W}, 285 \mathrm{~m}$ alt., humid zone, agricultural area, fenced pastures with old trees (Cedrela odorata, Persea americana, Citrus sp.), on wood, 28-Feb-2006, Aptroot, A. 64699 (CDS 31273; along old trail from Puerto Ayora (Academy Bay) to Bellavista, $80 \mathrm{~m}$ alt., dry zone, on bark, 11-Apr-1976, Weber, W.A. s.n. (L-63325, COLO 297096). SAN CRISTÓBAL: near Rosa Blanca, inland from the SE-coast of the island, $0^{\circ} 49^{\prime} 13^{\prime \prime} \mathrm{S}, 89^{\circ} 21^{\prime} 41^{\prime \prime} \mathrm{W}, 13 \mathrm{~m}$ alt., dry zone, open Bursera graveolens woodland with Mentzelia aspera and Waltheria ovata shrubs on lava flow, on wood, 23-Apr-2007, Bungartz, F. 6388 (CDS 34603); northwestern foothills of Media Luna, inland from the NW-coast, $0^{\circ} 43^{\prime} 41^{\prime \prime} \mathrm{S}, 89^{\circ} 18^{\prime} 44^{\prime \prime} \mathrm{W}, 75 \mathrm{~m}$ alt., dry zone, open woodland of Cordia lutea and Bursera graveolens, on wood, 22-Apr-2007, Bungartz, F. 6218 (CDS 34430). FLOREANA: trail from Black Beach to highlands, on bark, 25-Apr-1976, Weber, W.A. s.n. (L-63249, COLO 296798); at La Lobería, $~ 50 \mathrm{~m}$ inland, $1^{\circ} 16^{\prime} 58^{\prime \prime} \mathrm{S}, 90^{\circ} 29^{\prime} 26^{\prime \prime} \mathrm{W}, 16 \mathrm{~m}$ alt., dry zone, very open Bursera forest with Waltheria ovata, Croton scouleri, few Lantana peduncularis and Mentzelia aspera on lava flow, on bark, 16-Jan-2011, Yánez-Ayabaca, A. 1994 (CDS 48344). SANTIAGO: E of salt lake at Santiago Bay, $0^{\circ} 14^{\prime} 25^{\prime \prime} \mathrm{S}, 90^{\circ} 49^{\prime} 40^{\prime \prime} \mathrm{W}, 70 \mathrm{~m}$ alt., dry zone, open Bursera forest on pahoehoe lava flow, on bark, 30-Apr-1971, Pike, L.H. 2681 (L-56168, COLO 263245), 2681 (OSC 53468), ID15-15 (OSC 53466); on side of easternmost crater in the highlands, $0^{\circ} 14^{\prime} 20^{\prime \prime} \mathrm{S}, 90^{\circ} 42^{\prime} 45^{\prime \prime} \mathrm{W}, 350 \mathrm{~m}$ alt., transition zone, on bark, 10-May-1971, Pike, L.H. 2117 (L-55205, COLO 255633), 2117 (OSC 53465); $0.5 \mathrm{~km} \mathrm{~W}$ of the spring at Santiago Bay, $0^{\circ} 15^{\prime} 0^{\prime \prime} \mathrm{S}, 90^{\circ} 51^{\prime} 30^{\prime \prime} \mathrm{W}$, m alt., on bark, 24-Apr-1971, Pike, L.H. 2605 (L-55221, COLO 255649), 2605 (OSC 53469); 0.4 km $\mathrm{S}$ of James Bay, $0^{\circ} 14^{\prime} 30^{\prime \prime} \mathrm{S}, 90^{\circ} 51^{\prime} 30^{\prime \prime} \mathrm{W}, 7 \mathrm{~m}$ alt., dry zone, open Bursera forest on consolidated ash, on bark, 25-Apr-1971, Pike, L.H. 2541 (OSC 53467); along the trail from Bucanero to Jaboncillos, $3 \mathrm{~km}$ SE of Bucanero, $0^{\circ} 10^{\prime} 52^{\prime \prime} \mathrm{S}, 90^{\circ} 48^{\prime} 33^{\prime \prime} \mathrm{W}$, $362 \mathrm{~m}$ alt., transition zone, open woodland of large Bursera graveolens and smaller Psidium galapageium trees, grassland and basalt boulders in between, on wood \& bark, 22-Mar-2006, Aptroot, A. 65379 A (CDS 31965).

\section{New combinations of Phaeoplaca species not reported from the Galapagos}

Phaeoplaca camptidia (Tuck.) Søchting, Arup \& Bungartz, comb. nov.

\section{MycoBank MB 836951}

Basionym: Lecanora camptidia Tuck., Proceedings of the American Academy of Arts and Sciences 5: 403. 1862; MycoBank MB 387806.

Phaeoplaca ochrolechioides (S.Y. Kondr. \& Kärnefelt) Søchting \& Arup, comb. nov.

MycoBank MB 836953 
Basionym: Caloplaca ochrolechioides S.Y. Kondr. \& Kärnefelt, in Kondratyuk, Elix, Kärnefelt \& Thell, Biblthca Lichenol. 106: 180. 2011; MycoBank MB 569757.

Sucioplaca Bungartz, Søchting \& Arup, gen. nov.

MycoBank MB 836961

Generic type: Sucioplaca diplacia (Ach.) Bungartz, Søchting \& Arup, ibid.

Diagnosis. Thallus saxicolous on coastal rocks, crustose, rimose, often sorediate, bluish gray. Apothecia rare, lecanorine, asci clavate, of Teloschistes-type, with 8 spores. Ascospores polaribilocular, broadly ellipsoid to subglobose with a thick septum. Phylogenetically Sucioplaca occupies a very isolated position on a distinct clade in Caloplacoideae with presently only one species.

Chemistry. Thallus with atranorin, isofulgidin, vicanicin and caloploicin.

Etymology. The genus name is a combination of the syllables '-placa' hinting at Caloplaca (from which species in the genus were transferred), and the Spanish word 'sucio-', meaning 'dirty', a reference to the dust-rich habitats close to the ground, where the only known species typically grows.

Known distribution. Widely distributed and common in Central America, particularly around the Caribbean Sea.

Sucioplaca diplacia (Ach.) Bungartz, Søchting \& Arup, comb. nov.

(Figs 1-2, 17)

MycoBank MB 836962

Basionym: Lecanora diplacia Ach., Syn. meth. lich. (Lund): 154. 1814; MycoBank MB 388093.

Caloplaca diplacia (Ach.) Riddle, Memoirs of the Brooklyn botanical Garden 1: 113. 1918; MycoBank MB 381493.

Description. Thallus rimose to rimose-areolate, thin to strongly thickened, \pm effuse, but typically delimited by a compact blackish prothallus, although compatible thalli are confluent, not distinctly separated, merging with one another; surface dark to pale bluish gray, sometimes tinged with a pinkish hue, smooth, but not shiny, epruinose, with laminal, strongly pustulate and frequently confluent soralia, $0.2-0.5(-0.7) \mathrm{mm}$ in diam. (larger if confluent), with farinose pale green soredia $[(20-) 25-35(-40) \mu \mathrm{m}$ in diam.], which are, if not eroded, typically strongly tinged bluish black. Apothecia mostly absent, if present, dispersed to loosely aggregated, rarely very closely grouped and strongly deformed ('gall-forming'), sessile, up to $1 \mathrm{~mm}$ in diam., but mostly smaller, lecanorine (although appearing 'biatorine' or even 'lecideine', initially pale, but soon discolored, first becoming reddish-black and increasingly darkening, with maturity the entire surface deep reddish-black, the discoloration either starting with the disc, eventually extending to the margin, or first the margin becoming pigmented, later the disc); thalline margin regular to deformed, moderately to strongly thickened, up to $160 \mu \mathrm{m}, \pm$ waxy and smooth, initially pale, 'fleshy', almost transparent, soon irregularly tinged reddish-black, eventually deeply blackened throughout, epruinose, $\mathrm{C}-$, $\mathrm{K}-$; disc plane, smooth, initially pale, whitish to almost transparent ('glassy'), soon irregularly tinged reddish-black, eventually deeply blackened throughout, epruinose, $\mathrm{C}-, \mathrm{K}-$; epihymenium reddish orange to strongly violaceous, pigmentation diffuse, $\mathrm{C}+$ yellowish brown, $\mathrm{K}-$, pigment granules absent, \pm contiguous with the outer exciple; hymenium hyaline, not inspersed; proper exciple indistinct, almost entirely reduced to a few hyaline hyphae; thalline exciple differentiated into a central, lower part with abundant trebouxioid photobionts, a transitional part abundantly filled with small crystals that dissolve in $\mathrm{K}$, and an outer part, which is initially pale, but with age becomes increasingly pigmented by a reddish orange to strongly violaceous pigment, $\mathrm{C}+$ yellowish brown, $\mathrm{K}-$; subhymenium grayish, hypothecium hyaline, both not inspersed; asci clavate, Teloschistes-type; ascospores 8/ ascus, polaribilocular, broadly ellipsoid to almost globose, (7.1-)8.9-11.0(-11.5) × (3.9-)4.9-7.0(-8.3) $\mu \mathrm{m}$, with a thick, (2.7-)3.4-5.3(-6.4) $\mu \mathrm{m}$ wide septum $(\mathrm{n}=35)$. Pycnidia not observed.

Chemistry. Thallus $\mathrm{P}+$ yellow, $\mathrm{K}+$ yellow, $\mathrm{C}-, \mathrm{KC}-$, $\mathrm{UV}-$ (dull), apothecia $\mathrm{P}-, \mathrm{K}-, \mathrm{C}-, \mathrm{KC}-, \mathrm{UV}-($ dull); thallus with atranorin, isofulgidin, vicanicin and caloploicin.

Ecology and distribution. Originally described from St. Thomas (Virgin Islands), but on coastal rock probably very widely distributed throughout the Caribbean or even Central America. In Galapagos, this is probably the most abundant saxicolous species of Caloplaca s.l. Specimens have been collected especially along the coast throughout the dry zone into the lower transition zone, but the species can occasionally still be found even in the lower humid zone. It typically grows in \pm sheltered, semi-shaded, \pm nitrophytic, dust-rich habitats, often close to the ground, but one specimen (Aptroot, A. 64559, CDS 31131) has been collected on bark.

Note. In the field, specimens of Sucioplaca diplacia can easily be confused with several superficially similar species of Lecanora that often grow together in the same habitat, even side by side on the same rock (see Bungartz et al. 2020).

Lecanora austrosorediosa is perhaps the species most similar to $S$. diplacia. Both form sorediate thalli with apothecia transitioning from pale to dark. Soralia of $S$. diplacia are strongly pustulate, frequently confluent, their outer surface, when not eroded, typically tinged a dark bluish gray. Soralia of L. austrosorediosa are rarely confluent, pale creamy beige, not discolored by a bluish or blackish tinge. The species consistently forms thin, pale, whitish gray, rimose-areolate thalli, sometimes with a whitish prothallus, rarely delimited by a thin, black line. Thalli of $S$. diplacia are instead deeply lead to olive gray, generally much thicker, more irregular, its areoles in part almost subsquamulose; the thallus is typically delimited by a thick, conspicuous, black prothallus.

The two species have apothecia that are confusingly similar, both initially pallid. In L. austrosorediosa, 
apothecia are a pale creamy white, of a 'waxy' appearance. In $S$. diplacia, they are initially colorless, ' \pm glassy', almost transparent. The apothecia of both species become at least partially discolored with age. In both species, they turn distinctly dark, ultimately blackening with age. The pigments causing this transition are, however, different: apothecia of $S$. diplacia become disfigured by a deep violet to purple. These blackened parts of the apothecia thus have a violaceous hue. Eventually, apothecia of $S$. diplacia appear lecideine, carbonized throughout. In L. austrosorediosa, the pigment is instead a grayish black, apothecia become irregularly carbonized, but they are rarely completely blackened throughout.

In section, the different color of both pigments is immediately evident, but then of course the two species can also be distinguished by their spores and asci: Sucioplaca has polardiblastic spores produced in Teloschistes-type asci; Lecanora has simple spores in Lecanora-type asci. Chemically, the two species are also distinct: though both contain atranorin, L. austrosorediosa is further characterized by \pm 2 '-O-methylhyperlatolic acid (or closely related secondary metabolites) and zeorin, whereas $S$. diplacia contains isofulgidin, vicanicin and caloploicin.

Sterile specimens of $S$. diplacia (i.e., those with soralia only) could further be confused with sorediate specimens of L. avium or L. prosecha. Both Lecanora species, when well developed, form areoles with distinctly interlocking, serrate margins. These thalli, therefore, do not resemble those of Sucioplaca, even though sterile specimens of $L$. avium may have bluish gray soralia. Soralia of L. prosecha are pale, creamy white, similar to the ones of $L$. austrosorediosa, but the species has cryptolecanorine apothecia.

Schumm \& Aptroot (2019b) refer to the sorediate morphotype as Caloplaca diplacioides (Vain.) Zahlbr. The protologue of this taxon, however, doesn't suggest that apothecia are always absent. Instead, Vainio (1896, p. 67) describes apothecia of Placodium diplacioides Vain. as '... only rarely forming and often partially developed ...'
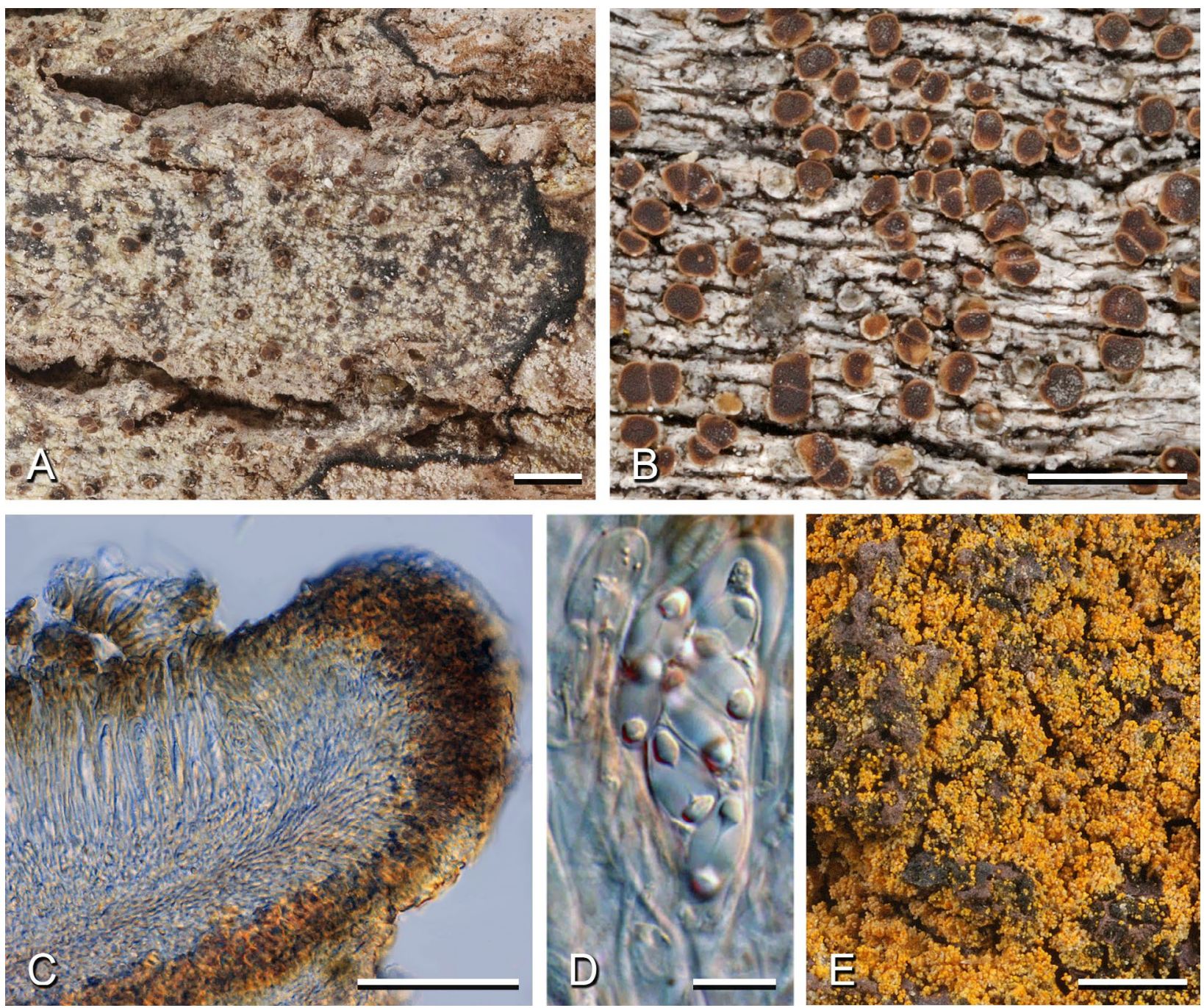

Figure 12. Species of Caloplaca. A-D - Phaeoplaca tortuca. A - thallus thin, \pm granular, in part endosubstratal, with distinct black prothallus, in part extending as hypothallus in between the thallus granules, apothecial discs deep brown (Bungartz, F. 5512, CDS 32853); B - thallus thin, rimose, apothecia with deep brown disc and paler margin (Bungartz, F. 3644, CDS 27462); C - apothecial section: biatorine, outer exciple and epihymenium deep brown (Aptroot, A. 64699, CDS 31273-holotype); D - ascus with ellipsoid ascospores, septum broad [DIC, in water] (Aptroot, A. 65189 A, CDS 31773); E - Leproplaca chrysodeta, thallus entirely composed of leproid, pseudocorticate granules (Bungartz, F. 7595, CDS 38091). Scales: A-B, $\mathrm{E}=2 \mathrm{~mm} ; \mathrm{C}=100 \mu \mathrm{m} ; \mathrm{D}=10 \mu \mathrm{m}$. 
('apothecia increbra et saepe parcius evoluta'). Clearly, there is no molecular evidence that the sorediate morphotype of Sucioplaca diplacia warrants taxonomic recognition and specimens are regularly both sorediate and apotheciate (Fig. 17A, C). We have not examined type material of $C$. diplacioides, but it is possible that the taxon must be considered a synonym.

Specimens examined from Ecuador, Galápagos. ISABELA, VOLCÁN ALCEDO: outer SE-exposed slope, $~ 100$ m below the crater rim, $0^{\circ} 25^{\prime} 36^{\prime \prime} \mathrm{S}, 91^{\circ} 5^{\prime} 12^{\prime \prime} \mathrm{W}, 1146 \mathrm{~m}$ alt., humid zone, disturbed by former grazing of goats, Pteridium arachnoideum and Stachytarpheta cayennensis, scattered low shrubs of Tournefortia rufo-sericea and outcrops of basalt tuff in between, on rock, 06-Mar-2006, Bungartz, F. 4139 (CDS 28170); along the trail going up the E-slope, basalt rubble field to the SE-side of the trail and the barranco, $0^{\circ} 24^{\prime} 3^{\prime \prime} \mathrm{S}, 91^{\circ} 2^{\prime} 35^{\prime \prime} \mathrm{W}, 434 \mathrm{~m}$ alt., dry zone, basalt rubble field with scattered vegetation (Bursera graveolens, Zanthoxylum fagara, Pisonia floribunda, Senna pistaciifolia), on rock, 09-Mar-2006, Aptroot, A. 64978 (CDS 31558 ); on the crater rim near the hut, $0^{\circ} 26^{\prime} 33^{\prime \prime} \mathrm{S}, 91^{\circ} 5^{\prime} 31^{\prime \prime} \mathrm{W}$, $1100 \mathrm{~m}$ alt., humid zone, Pteridium arachnoideum and Stachytarpheta cayennensis, scattered low shrubs of Tournefortia rufo-sericea and outcrops of basalt tuff in between, on rock, 07-Mar-2006, Aptroot, A. 65288 (CDS 31874), 65269 (CDS 31855). VOLCÁN DARWIN: southwestern foothills, above Tagus Cove (1st campsite), $0^{\circ} 14^{\prime} 50^{\prime \prime} \mathrm{S}, 91^{\circ} 21^{\prime} 29^{\prime \prime} \mathrm{W}, 67 \mathrm{~m}$ alt., dry zone, open Bursera graveolens forest with Waltheria ovata and Macraea laricifolia, few Acacia rorudiana and Cordia lutea, along small lava flow, on rock, 11-Nov-2007, Bungartz, F. 7339 (CDS 37826); southwestern slope, above Tagus Cove, $0^{\circ} 13^{\prime} 27^{\prime \prime} \mathrm{S}$, $91^{\circ} 19^{\prime} 19^{\prime \prime} \mathrm{W}, 874 \mathrm{~m}$ alt., transition zone, top of lava flow in open scrubland of Croton scouleri and Dodonaea viscosa with Cordia revoluta and some Opuntia insularis, on rock, 15-Nov2007, Bungartz, F. 7723 (CDS 38227). VOLCÁN CERRO AZUL: lower crater slopes above the first Caseta del Parque; within the cloud layer, $0^{\circ} 57^{\prime} 55^{\prime \prime} \mathrm{S}, 91^{\circ} 25^{\prime} 1.899^{\prime \prime} \mathrm{W}, 767 \mathrm{~m}$ alt., humid zone, open pasture with some Tournefortia rufo-sericea scrub, and occasional large clusters of Cladonia confusa on the ground, on rock, 03-May-2012, Bungartz, F. 10331 (CDS 52304); lower half of path from the Caseta del Parque to Caleta Iguana at the coast, $0^{\circ} 58^{\prime} 52^{\prime \prime} \mathrm{S}, 91^{\circ} 26^{\prime} 41^{\prime \prime} \mathrm{W}, 74 \mathrm{~m}$ alt., dry zone, shaded forest of huge Manzanillo (Hippomane mancinella) trees, some Zanthoxylum fagara scrub, shrubs of Clerodendrum molle and Psidium galapageium, on rock, 09-May-2012, Bungartz, F. 10470 (CDS 52432), 10536 (CDS 52548). VOLCÁN SIERRA NEGRA: top of the northern crater rim, $0^{\circ} 48^{\prime} 3^{\prime \prime} \mathrm{S}$, $91^{\circ} 5^{\prime} 25^{\prime \prime} \mathrm{W}, 968 \mathrm{~m}$ alt., humid zone, SW-exposed basalt cliffs among dry vegetation of grasses and herbs, on rock, 08-Sep2007, Bungartz, F. 6787 (CDS 36206); Muro de las Lagrimas $\mathrm{W}$ of Puerto Villamil, along the stairs going up behind the wall, $0^{\circ} 57^{\prime} 52^{\prime \prime} \mathrm{S}, 91^{\circ} 0^{\prime} 46^{\prime \prime} \mathrm{W}, 78 \mathrm{~m}$ alt., dry zone, dry zone vegetation with Bursera graveolens and Opuntia echios, slope $45^{\circ} \mathrm{N}$, on rock, 17-Aug-2008, Truong, C. 1288 (CDS 39599); Herrera-Campos, M.A. 10737 (CDS 40475); Bungartz, F. 8442 (CDS 41088); around the mirador El Mango, $0^{\circ} 53^{\prime} 2^{\prime \prime} \mathrm{S}, 91^{\circ} 0^{\prime} 51^{\prime \prime} \mathrm{W}$, $174 \mathrm{~m}$ alt., transition zone, mixed stand with Cedrela odorata and Kalanchoe pinnata invading the understory, slope $15^{\circ} \mathrm{SE}$, on rock, 15-Aug-2008, Clerc, P. 08-230 (CDS 40084). PINTA: at the S-coast, a little $\mathrm{E}$ of Cabo Chalmers, $0^{\circ} 33^{\prime} 2^{\prime \prime} \mathrm{N}, 90^{\circ} 46^{\prime} 3^{\prime \prime} \mathrm{W}$, $10 \mathrm{~m}$ alt., dry zone, old lava flow with scarce vegetation (Opuntia galapageia, Alternanthera filifolia, Prosopis juliflora), on rock, 01-Mar-2007, Bungartz, F. 6058 (CDS 33737). SANTA CRUZ: Puerto Ayora, cliff $\mathrm{N}$ of the town, $0^{\circ} 43^{\prime} 59^{\prime \prime} \mathrm{S}$, $90^{\circ} 18^{\prime} 45^{\prime \prime} \mathrm{W}, 20 \mathrm{~m}$ alt., dry zone, on rock, 11-Feb-2006,
Aptroot, A. 63732 A (CDS 30289), 63733 (CDS 30291); along the S-coast of the island, just E of the Charles Darwin Research Station (CDRS), $0^{\circ} 44^{\prime} 35^{\prime \prime} \mathrm{S}, 90^{\circ} 18^{\prime} 12^{\prime \prime} \mathrm{W}, 2 \mathrm{~m}$ alt., coastal zone, coastal scrubland with Rhizophora mangle, Hippomane mancinella, and Cryptocarpus pyriformis, on rock, 18-Oct-2007, Ertz, D. 11540 (CDS 36864); $0^{\circ} 44^{\prime} 35^{\prime \prime} \mathrm{S}, 90^{\circ} 18^{\prime} 14^{\prime \prime} \mathrm{W}, 1 \mathrm{~m}$ alt., coastal zone, bare lava rocks, Cryptocarpus pyriformis occasionally in between, on rock, 10-Feb-2006, Bungartz, F. 3411 (CDS 27117), 3418 (CDS 27124); $0^{\circ} 44^{\prime} 32^{\prime \prime} \mathrm{S}, 90^{\circ} 18^{\prime} 10^{\prime \prime} \mathrm{W}, 5 \mathrm{~m}$ alt., coastal zone, on rock, 24-May-2005, Aptroot, A. 63124 (CDS 29854); near begin of road to Baltra, $0^{\circ} 44^{\prime} 34^{\prime \prime} \mathrm{S}, 90^{\circ} 18^{\prime} 45^{\prime \prime} \mathrm{W}, 25 \mathrm{~m}$ alt., dry zone, on rock, 26-May-2005, Aptroot, A. 63082 (CDS 29810); $0^{\circ} 34^{\prime} 22^{\prime \prime} \mathrm{S}, 90^{\circ} 19^{\prime} 55^{\prime \prime} \mathrm{W}, 27 \mathrm{~m}$ alt., dry zone, dry deciduous lowland forest (Bursera graveolens, Heliotropium sp., Acacia sp., Zanthoxylum fagara), on rock, 23-Feb-2006, Aptroot,

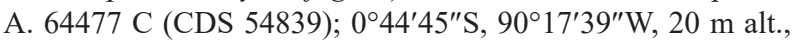
coastal zone, on rock, 29-May-2005, Aptroot, A. 63296 (CDS 30036), 63282 (CDS 30022); along the road from Bellavista to El Garrapatero, at the boundary of the National Park, $0^{\circ} 40^{\prime} 14^{\prime \prime} \mathrm{S}$, $90^{\circ} 15^{\prime} 58^{\prime \prime} \mathrm{W}, 252 \mathrm{~m}$ alt., transition zone, with Zanthoxylum fagara, Lantana camara, Citrus sp. and Croton scouleri, on rock, 14-Feb-2006, Bungartz, F. 3552 (CDS 27351); along the road from Bellavista to Los Gemelos, $0^{\circ} 38^{\prime} 12^{\prime \prime} \mathrm{S}, 90^{\circ} 23^{\prime} 46^{\prime \prime} \mathrm{W}$, 574 m alt., humid zone, NNW-exposed road bank with annual vegetation partially dry and died-back, and some lava rocks along Scalesia pedunculata forest, on rock, 12-Feb-2006, Bungartz, F. 3457 (CDS 27172); near Puntudo, 0³8'41"S, $90^{\circ} 20^{\prime} 13^{\prime \prime} \mathrm{W}, 750 \mathrm{~m}$ alt., humid zone, on rock, 27-May-2005, Aptroot, A. 63210 (CDS 29942); along the road from Los Gemelos towards the N-coast of the island, $\sim 1.2 \mathrm{~km} \mathrm{~N}$ of Los Gemelos, $0^{\circ} 37^{\prime} 18^{\prime \prime} \mathrm{S}, 90^{\circ} 22^{\prime} 43^{\prime \prime} \mathrm{W}, 573 \mathrm{~m}$ alt., transition zone, upper transition zone; open dry decidous forest with Bursera graveolens, Psychotria rufipes, and Zanthoxylum fagara, on rock, 12-Feb-2006, Bungartz, F. 3527 A (CDS 27311); Aptroot, A. $63760\left(\right.$ CDS 30320); 1 km N of Los Gemelos, $0^{\circ} 37^{\prime} 22^{\prime \prime} \mathrm{S}$, $90^{\circ} 22^{\prime} 47^{\prime \prime} \mathrm{W}, 584 \mathrm{~m}$ alt., transition zone, upper transition zone with open dry forest, Scalesia pedunculata, Chiococca alba, Tournefortia rufo-sericea, Cordia leucophlyctis, and Zanthoxylum fagara, on rock, 12-Feb-2006, Bungartz, F. 3525 (CDS 27303 ); along the trail down into the crater at Camote, $0^{\circ} 38^{\prime} 10^{\prime \prime} \mathrm{S}$, $90^{\circ} 17^{\prime} 43^{\prime \prime} \mathrm{W}, 377 \mathrm{~m}$ alt., humid zone, steep, SE-exposed inner crater wall with open scrubland (Cestrum auriculatum, Chiococca alba, Croton scouleri, few Scalesia pedunculata and Pisonia floribunda), on rock, 19-Feb-2007, Bungartz, F. 5630 (CDS 33255), 5631 (CDS 33256); off the dirt road to Mina Granillo Rojo, on the N-side of the island, $0^{\circ} 37^{\prime} 2^{\prime \prime} \mathrm{S}, 90^{\circ} 22^{\prime} 6^{\prime \prime} \mathrm{W}$, $294 \mathrm{~m}$ alt., transition zone, deciduous forest of Zanthoxylum fagara, Psidium galapageium, Pisonia floribunda and few Bursera graveolens and Cedrela odorata, on rock, 21-Jun-2006, Bungartz, F. 4965 (CDS 29178); on the North side of the island, along the dirt road to the ash quarry Mina Granillo Rojo, $0^{\circ} 36^{\prime} 56^{\prime \prime} \mathrm{S}, 90^{\circ} 22^{\prime} 3^{\prime \prime} \mathrm{W}, 570 \mathrm{~m}$ alt., transition zone, lower transition zone; dry semi-deciduous forest with Bursera graveolens and Zanthoxylum fagara, on bark, 23-Feb-2006, Aptroot, A. 64559 (CDS 31131). SAN CRISTÓBAL: trail to Ochoa, along the nothern border of the National Park, ca $1 \mathrm{~km} \mathrm{~N}$ of El Progreso, $0^{\circ} 53^{\prime} 32^{\prime \prime} \mathrm{S}, 89^{\circ} 33^{\prime} 18^{\prime \prime} \mathrm{W}, 294 \mathrm{~m}$ alt., transition zone, basalt outcrop just outside the farm area, shaded by vegetation, on rock, 24-Aug-2008, Bungartz, F. 8648 (CDS 41294); trail to Cerro Mundo, passing by the 'cañadas', $0^{\circ} 53^{\prime} 33^{\prime \prime} \mathrm{S}, 89^{\circ} 34^{\prime} 40^{\prime \prime} \mathrm{W}$, $200 \mathrm{~m}$ alt., transition zone, with Hippomane mancinella, Zanthoxylum fagara, Psidium galapageium, P. guajava and Kalanchoe pinnata and Mormordica charantia invading the understory, slope $10^{\circ}-25^{\circ} \mathrm{WNW}$, on rock, 25-Aug-2008, Herrera-Campos, M.A. GAL-491 (CDS 43382); 053'32"S, $89^{\circ} 34^{\prime} 40^{\prime \prime} \mathrm{W}, 212 \mathrm{~m}$ alt., transition zone, forest stand of 

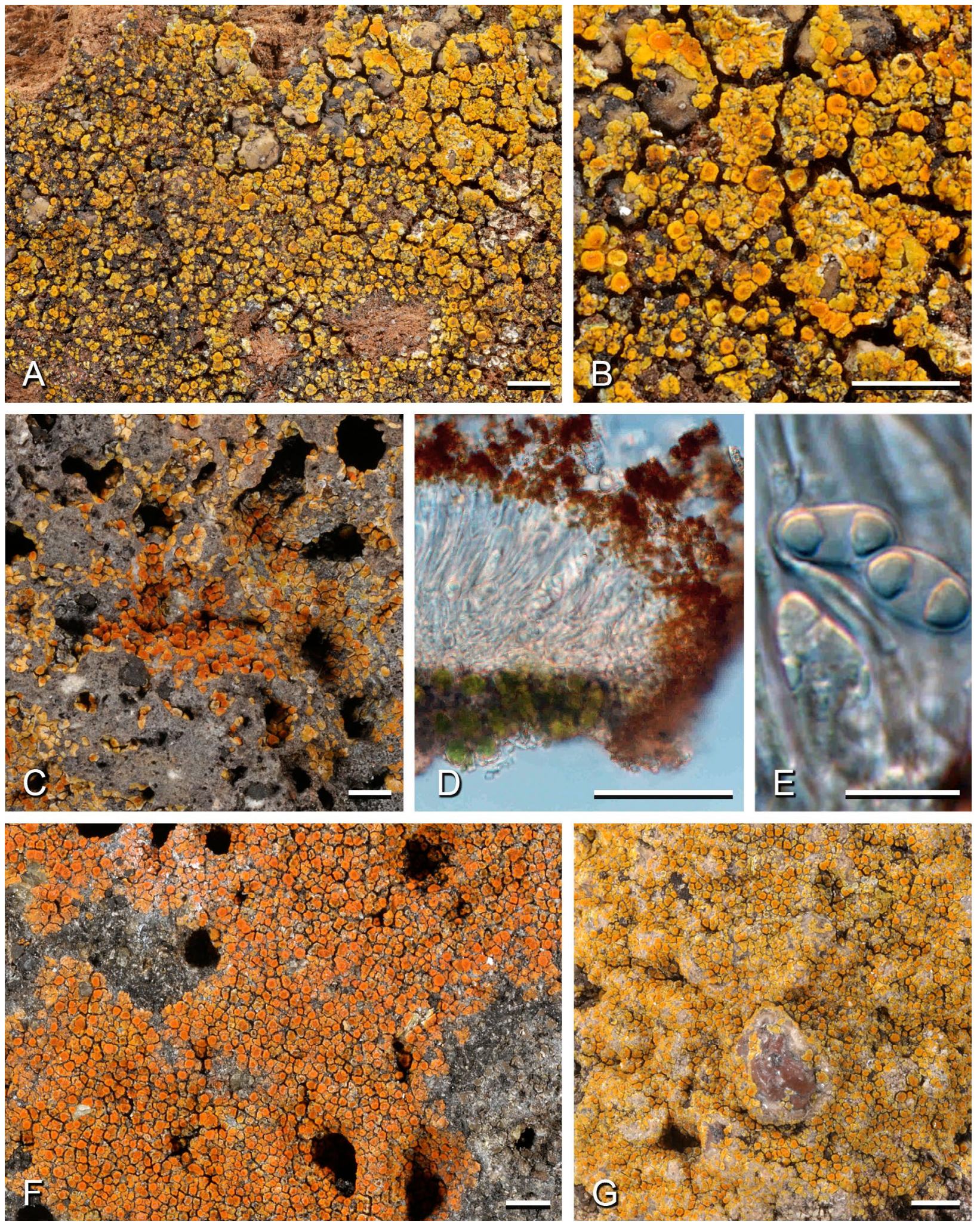

Figure 13. Species of Squamulea. A-B - Squamulea flakusii (Aptroot, A. 65261, CDS 31847). A - Overview of the deep yellow thallus; B Detail of the thallus composed of closely aggregating sublobate squamules with adnate apothecia. C-E - Squamulea chelonia (Bungartz, F. 6146, CDS 34358-holotype); C - Thallus of scattered, barely subsquamulose, deep yellow to orange areoles and immersed to adnate deep orange apothecia; D - Apothecial section: lecanorine, outer thalline exciple densely filled with orange granules, central part with trebouxioid green algae, epihymenium with abundant orange granules [DIC, in water]; E - oblong ascospores with moderately thickened septum [DIC, in water]. F-G - Squamulea oceanica. F - Deep orange thallus of scattered, angular to barely subsquamulose areoles and deep orange, adnate apothecia (Bungartz, F. 3412, CDS 27118); G - Deep yellow thallus of scattered, angular to barely subsquamulose areoles and deep orange, adnate apothecia, the substrate in between the areoles inconspicuously coated by a thin whitish hypothallus (Bungartz, F. 6529, CDS 34747). Scales: $\mathrm{A}-\mathrm{C}, \mathrm{F}-\mathrm{G}=2 \mathrm{~mm} ; \mathrm{D}=100 \mu \mathrm{m} ; \mathrm{E}=10 \mu \mathrm{m}$. 
Hippomane mancinella and Zanthoxylum fagara, with basaltic rocks covering the ground, slope $15^{\circ} \mathrm{W}$, on rock, 25-Aug-2008, Clerc, P. 08-384 (CDS 40238); plain between Cerro Pelado and Cerro Partido, S of El Ripioso, 0 $51^{\prime} 27^{\prime \prime} \mathrm{S}, 8^{\circ} 27^{\prime} 36^{\prime \prime} \mathrm{W}, 366 \mathrm{~m}$ alt., transition zone, open plane with lava rocks and shrubs of Clerodendrum molle var. glabrescens, on rock, 28-Apr-2007, Bungartz, F. 6658 (CDS 34894). FLOREANA: caldera of Cerro Pajas, trail at the end of road leading up to crater rim, $1^{\circ} 17^{\prime} 47^{\prime \prime} \mathrm{S}$, $90^{\circ} 27^{\prime} 23^{\prime \prime} \mathrm{W}$, humid zone, forest, on rock, 02-Jan-2010, Hillmann, G. GAL-132 (CDS 44807), GAL-131 (CDS 44811), GAL-134 (CDS 44812), GAL-141 (CDS 44825); Cerro Pajas, inside the crater, around the small hut, at the end of trail off the dirt road to the highlands, $1^{\circ} 17^{\prime} 50^{\prime \prime} \mathrm{S}, 90^{\circ} 27^{\prime} 23^{\prime \prime} \mathrm{W}, 376 \mathrm{~m}$ alt., humid zone, open, SE-exposed slope of lava cliff and boulders with some ferns, on rock, 12-Jan-2011, Bungartz, F. 9369 (CDS 46656), 9370 (CDS 46657); at the base of Cerro Comunista, $1^{\circ} 17^{\prime} 22^{\prime \prime} \mathrm{S}, 90^{\circ} 28^{\prime} 22^{\prime \prime} \mathrm{W}, 158 \mathrm{~m}$ alt., dry zone, dense low forest of Croton scouleri, Waltheria ovata and Castela galapageia with occasional trees of Acacia rorudiana and Bursera graveolens, on rock, 16-Jan-2011, Bungartz, F. 9691 (CDS 47008); lower S-slope of Cerro Ventanas, $1^{\circ} 16^{\prime} 36^{\prime \prime} \mathrm{S}, 90^{\circ} 25^{\prime} 41^{\prime \prime} \mathrm{W}, 295 \mathrm{~m}$ alt., transition zone, open shrubland of Macraea laricifolia and some lower Waltheria ovata shrubs in between, on rock, 18-Jan2011, Bungartz, F. 9855 (CDS 47193); Yánez-Ayabaca, A. 2022 (CDS 48372); inside the crater of Cerro Laguna at E-side of island, on W-exposed slope, $1^{\circ} 16^{\prime} 11^{\prime \prime} \mathrm{S}, 90^{\circ} 23^{\prime} 17^{\prime \prime} \mathrm{W}, 245 \mathrm{~m}$ alt., transition zone, dense forest of Prosopis juliflora, Clerodendrum molle, very few Bursera graveolens and some Jasminocereus thouarsii in the upper part among lava outcrops and boulders; Ramalina usnea/anceps hanging in cutains from Clerodendrum twigs, on rock, 20-Jan-2011, Bungartz, F. 9967 (CDS 47336); trail from La Primavera Farm to La Corona and Arco de la Reina, southeastern part of the island, $1^{\circ} 19^{\prime} 21^{\prime \prime} \mathrm{S}$, $90^{\circ} 24^{\prime} 45^{\prime \prime} \mathrm{W}, 219 \mathrm{~m}$ alt., transition zone, very dense scrub of Clerodendrum molle with some Croton scouleri, Waltheria ovata, few Prosopis juliflora and occasional trees of Geoffroea spinosa in flat area on generally SE-exposed, moderately inclined slope with few boulders, on rock, 24-Jan-2011, Bungartz, F. 10150 (CDS 47569). SANTIAGO: 5 km inland from the E-coast, \pm at the same latitude as Bahía Sullivan, $0^{\circ} 16^{\prime} 37^{\prime \prime} \mathrm{S}$, $90^{\circ} 37^{\prime} 24^{\prime \prime} \mathrm{W}, 163 \mathrm{~m}$ alt., dry zone, SE-exposed slope of lava boulders, on rock, 18-Jul-2006, Bungartz, F. 5217 (CDS 29430); summit of Cerro Gavilan, inner N- and NE-exposed crater rim, $0^{\circ} 12^{\prime} 20^{\prime \prime} \mathrm{S}, 90^{\circ} 47^{\prime} 3^{\prime \prime} \mathrm{W}, 840 \mathrm{~m}$ alt., humid zone, N- and NE-exposed, steep basalt cliffs of crater rim with ferns (Pityrograma calomelanos var. calomelanos, Polypodium tridens, Dryopteris palmata, Adiantum concinnum, Blechnum polypodioides) growing in crevices, on rock, 23-Mar-2006, Bungartz, F. 4801 B (CDS 28933); outer S-exposed crater rim, $0^{\circ} 12^{\prime} 23^{\prime \prime} \mathrm{S}, 90^{\circ} 47^{\prime} 4^{\prime \prime} \mathrm{W}$, $814 \mathrm{~m}$ alt., humid zone, S-exposed, steep basalt cliffs of crater rim with ferns (Pityrograma calomelanos var. calomelanos, Polypodium tridens, Dryopteris palmata, Adiantum concinnum, Blechnum polypodioides) growing in crevices, on rock, 24-Mar2006, Bungartz, F. 4815 (CDS 28979); area around the entrance of the lava tunnel at La Central, $0^{\circ} 14^{\prime} 23^{\prime \prime} \mathrm{S}, 90^{\circ} 45^{\prime} 8^{\prime \prime} \mathrm{W}, 667 \mathrm{~m}$ alt., humid zone, vertical cliffs around the entrance of the lava tunnel overgrown by ferns (Nephrolepis pectinata, Blechnum occidentale, Thelypteris hispidula, T. conspersa, Megalastrum pleiosorus, Tectaria aequatoriensis, and Trichomanes reptans), on rock, 24-Mar-2006, Bungartz, F. 4840 (CDS 29016); along the trail from Bucanero to Jaboncillos, $\sim 3 \mathrm{~km}$ SE of Bucanero, $0^{\circ} 10^{\prime} 52^{\prime \prime} \mathrm{S}, 90^{\circ} 48^{\prime} 33^{\prime \prime} \mathrm{W}, 362 \mathrm{~m}$ alt., transition zone, open woodland of large Bursera graveolens and smaller Psidium galapageium trees, grassland and basalt boulders in between, on rock, 22-Mar-2006, Bungartz, F. 4627 (CDS 28714); 7 km inland from the E-coast, \pm at the same latitude as Bahía Sullivan, $0^{\circ} 17^{\prime} 1^{\prime \prime} \mathrm{S}, 90^{\circ} 38^{\prime} 24^{\prime \prime} \mathrm{W}, 183 \mathrm{~m}$ alt., dry zone, SE-exposed slope of lava flow, on rock, 17-Jul-2006, Bungartz, F. 5145 (CDS 29358). PINTA: along the trail up to the summit from the S-coast, $0^{\circ} 34^{\prime} 3^{\prime \prime} \mathrm{N}, 90^{\circ} 44^{\prime} 56^{\prime \prime} \mathrm{W}, 233 \mathrm{~m}$ alt., transition zone, open woodland with Bursera graveolens, Zanthoxylum fagara, Pisonia floribunda, Croton scouleri, and few Opuntia galapageia among old lava flows; in between Alternanthera filifolia and grasses, on rock, 28-Feb-2007, Bungartz, F. 5964 (CDS 33642 ); at the S-coast, a little $\mathrm{E}$ of Cabo Chalmers, $0^{\circ} 33^{\prime} 2^{\prime \prime} \mathrm{N}$, $90^{\circ} 46^{\prime} 3^{\prime \prime} \mathrm{W}, 10 \mathrm{~m}$ alt., dry zone, old lava flow with scarce vegetation (Opuntia galapageia, Alternanthera filifolia, Prosopis juliflora), on rock, 01-Mar-2007, Bungartz, F. 6060 (CDS 33739); along the trail going up from Playa Escondida, $\mathrm{N}$ - to W-facing cliff above a crater, $0^{\circ} 36^{\prime} 29^{\prime \prime} \mathrm{S}, 90^{\circ} 40^{\prime} 14^{\prime \prime} \mathrm{W}$, $318 \mathrm{~m}$ alt., transition zone, dry transition zone with Cordia lutea, Croton scouleri, and at the bottom of the cliff also Scalesia baurii ssp. baurii, on rock, 16-Feb-2006, Aptroot, A. 64001 (CDS 30562). PINZÓN: in the valley on the W-slope of the highest mountain, $0^{\circ} 36^{\prime} 41^{\prime \prime} \mathrm{S}, 90^{\circ} 40^{\prime} 11^{\prime \prime} \mathrm{W}, 310 \mathrm{~m}$ alt., dry zone, dry zone vegetation with Prosopis juliflora, Alternanthera filifolia, Maytenus octogona, and Croton scouleri, on rock, 16-Feb-2006, Aptroot, A. 64090 (CDS 30651). ESPAÑOLA: along S-coast of the island, SE of Punta Suárez, $20 \mathrm{~m}$ inland from coast, $1^{\circ} 22^{\prime} 56^{\prime \prime} \mathrm{S}, 89^{\circ} 43^{\prime} 36^{\prime \prime} \mathrm{W}, 74 \mathrm{~m}$ alt., dry zone, Cordia lutea shrubland with Croton scouleri and Prosopis juliflora, on rock, 10-Nov-2010, Bungartz, F. 8904 (CDS 45722), 8905 (CDS 45723). ISLOTE GARDNER (ESPAÑOLA): N-part of the island, on top of the ridge, $1^{\circ} 20^{\prime} 32^{\prime \prime} \mathrm{S}, 89^{\circ} 38^{\prime} 42^{\prime \prime} \mathrm{W}, 47 \mathrm{~m}$ alt., dry zone, lava cliff with few trees of Bursera graveolens, Croton scouleri shrubs, and the vine Ipomoea habeliana, on rock, 12-Nov-2010, Bungartz, F. 9241 (CDS 46059).

Teloschistoideae Arup, Søchting \& Frödén, subfam. nov.

\section{MycoBank MB 837439}

Type genus: Teloschistes Norm.

Taxonomic note: The name was first introduced by Arup et al. (2013a), at the time without a valid diagnosis. Arup et al. (2013b) supplied this diagnosis, but referred to the Mycobank number originally introduced with the invalid name. Every new name, however, is required to be registered using its own unique identifier, the name thus remains invalid (a position recently again clarified by adoption of Art. F.5.7., May et al. 2019). Here, we register the subfamily Teloschistoideae with a new Mycobank number, thus finally validating the name.

For the diagnosis refer to Arup et al., Nordic J. Bot. 31: 256 (2013b).

'Caloplaca' cupulifera (Vain.) Zahlbr., Cat. Lich. Univers. 7: 226. 1931.

(Figs 2, 5A-B)

\section{MycoBank MB 381473}

Basionym: Placodium cupuliferum Vain., Ann. Acad. Sci. fenn., Ser. A 6(no. 7): 44. 1915; MycoBank MB 401079.

Taxonomic note: According to the phylogenies presented here, 'Caloplaca' cupulifera clearly belongs to the subfamily Teloschistoideae.

Description. Thallus rimose-areolate to areolate, marginal areoles irregularly lobate, but not distinctly effigurate, not placodioid; surface deeply chrome yellow, smooth, but not shiny, dull, epruinose, with laminal, crateriform ('cupuliform') soralia, $0.2-0.4 \mathrm{~mm}$ in diam., 

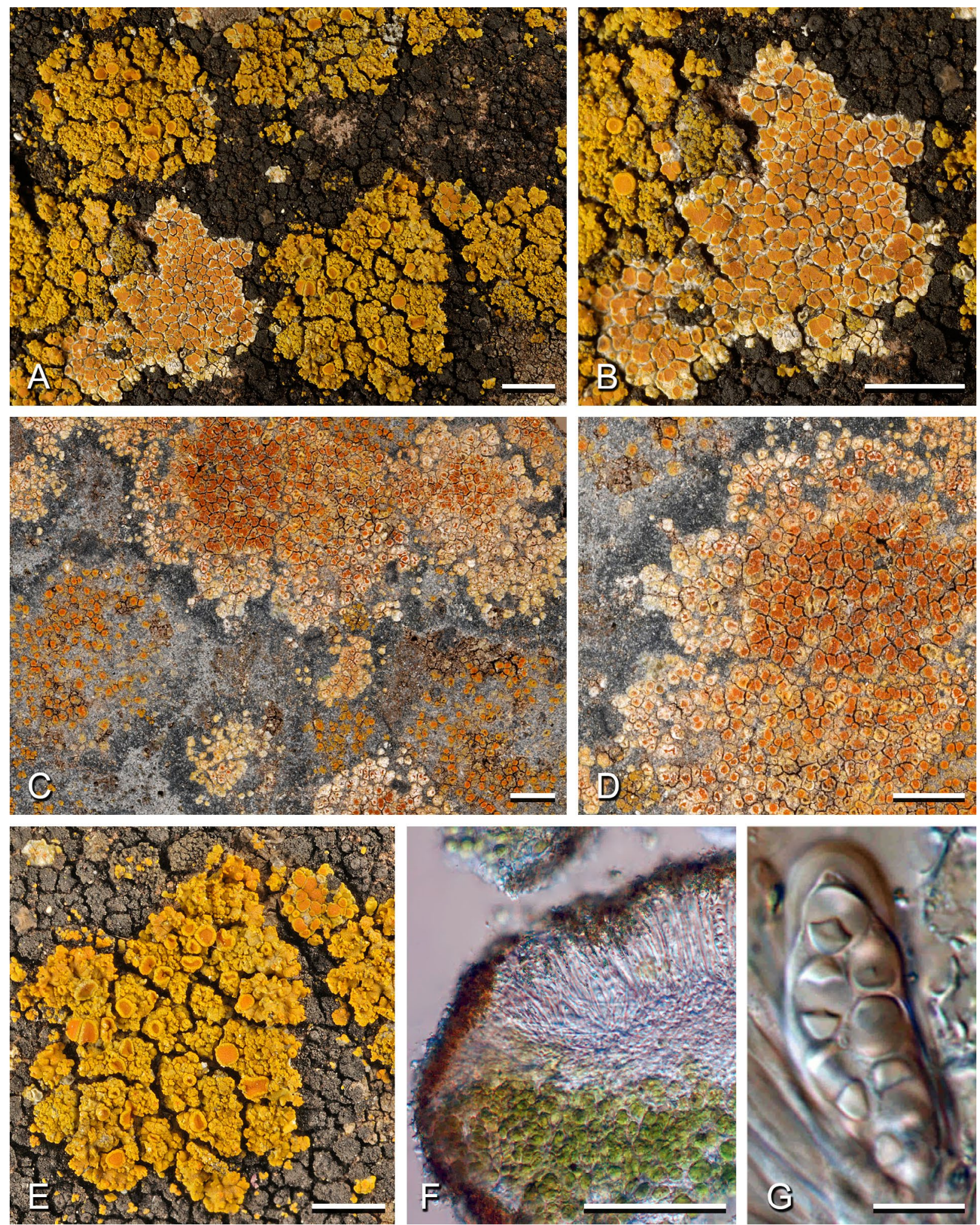

Figure 14. Species of Squamulea. A-B - Squamulea phyllidizans (Bungartz, F. 4709 A, CDS 28807) and S. humboldtiana (Bungartz, F. 4709 B, CDS 56234). A - Thalli of the distinctly squamulose, blastidiate, deep yellow Squamulea phyllidizans growing side by side with the angular, barely convex, abundantly pruinose areoles of $S$. humboldtiana; B - Close-up of $S$. humboldtiana (in the center); the deep yellow color of angular, barely convex areoles masked in part by a coarse pruina; also present is a deep yellow distinctly squamulose thallus with coarse blastidia of S. phyllidizans (at the left); C - Deep yellow, abundantly pruinose thalli of convex areoles of S. humboldtiana (Aptroot, A. 65718 B, CDS 56236) growing along scattered, deep yellow, epruinose angular areoles of S. oceanica (Aptroot, A. 65718 A, CDS 32310); the two different species delimited from one another by a black prothallus; the substrate in between the scattered areoles of $S$. oceanica inconspicuously coated by a thin whitish hypothallus; D - Deep yellow, abundantly pruinose thallus of S. humboldtiana, with convex to barely subsquamulose marginal areoles and angular ones in the center, apothecia emergent to adnate, angular, deforming one another, their thalline margin concolorous and as coarsely pruinose as the thallus, the disc deep orange, epruinose. E-G - Squamulea phyllidizans. E - Deep yellow, epruinose, distinctly squamulose thallus, the squamule margins lined by coarse, blastidate soredia, apothecia sessile, margin concolorous with the thallus, intact or breaking into blastidiate soredia, disc deep orange, epruinose (Bungartz, F. 4709 A, CDS 28807); F - Apothecial section: lecanorine, outer thalline exciple and epihymenium densely filled with orange granules, central exciple with trebouxioid green algae [DIC, in water] (Bungartz, F. 4710, CDS 28808); G - Ascus with broadly ellipsoid ascospores, septum moderately broad [DIC, in water] (Bungartz, F. 4709 A, CDS 28807). Scales: A-E = 2 mm; F = $100 \mu \mathrm{m} ; \mathrm{G}=10 \mu \mathrm{m}$. 
often deeply eroded and \pm excavate, with granular, bright yellow soredia (15-34 $\mu \mathrm{m}$ in diam.); prothallus absent. Apothecia unknown.

Chemistry. Thallus surface and soredia $\mathrm{P}-, \mathrm{K}+$ purple, C-, KC-, UV-(dull); dominated by fragilin, which is responsible for the conspicuous, chrome-yellow of the thallus and the bright yellow color of the soredia, occasionally also with small proportions of 7-chloroemodinal, 7-chloroemodic acid, 7-chloroemodin, and/or norcaloploicin.

Ecology and distribution. Possibly world-wide throughout the dry (sub-)tropics; Wetmore \& Kärnefelt (1998) originally reported the species only from the new world, e.g., Mexico, Central America (incl. Caribbean), Brazil and the Galapagos, but McCarthy (2016) also cites it for Australia; in Galapagos, the species seems to be quite common, particularly along the coast and throughout the dry zone, where it generally grows below shaded, sheltered overhangs.

Notes. Based on ITS sequence data Galapagos specimens of ' $C$.' cupulifera are very uniform. Slightly different ITS sequences from Australia suggest that different genotypes may be present in various regions of the world; these deserve further scrutiny (Fig. 2).

Specimens examined from Ecuador, Galápagos. SANTA CRUZ: on rock, Hill, T. s.n. (FH-TUCK 259996); Puerto Ayora, cliff $\mathrm{N}$ of the town, $0^{\circ} 43^{\prime} 59^{\prime \prime} \mathrm{S}, 90^{\circ} 18^{\prime} 45^{\prime \prime} \mathrm{W}, 20 \mathrm{~m}$ alt., dry zone, Bursera woodland, on rock, 11-Feb-2006, Aptroot, A. 63720 (CDS 30276); vicinity of Academy Bay, $0.5 \mathrm{mi}$ E of Darwin Station, coastal zone, shore boulders just above high tide mark, on rock, 15-Feb-1964, Weber, W.A. s.n. (L-40055, COLO 188284); along old trail from Puerto Ayora to Bella Vista, vertical rock faces of the barranca, on rock, 17-Jun-1972, Weber, W.A. s.n. (L-55399, COLO 256025). FLOREANA: lava flow behind beach ('White Beach') at SE side of Punta Cormorán, $\sim 100 \mathrm{~m}$ inland, $1^{\circ} 13^{\prime} 44^{\prime \prime} \mathrm{S}, 90^{\circ} 25^{\prime} 27^{\prime \prime} \mathrm{W}, 4 \mathrm{~m}$ alt., coastal zone, lava flow of weathered AA-lava with scarce vegetation of few Bursera trees and Mentzelia aspera, on rock, 19-Jan-2011, Bungartz, F. 9908 (CDS 47246); at La Lobería, $50 \mathrm{~m}$ inland, $1^{\circ} 16^{\prime} 58^{\prime \prime} \mathrm{S}$, $90^{\circ} 29^{\prime} 26^{\prime \prime} \mathrm{W}, 16 \mathrm{~m}$ alt., dry zone, very open Bursera forest with Waltheria ovata, Croton scouleri, few Lantana peduncularis and Mentzelia aspera on lava flow, on rock, 16-Jan-2011, Bungartz, F. 9746 (CDS 47063). ISLOTE CAMPÉON (FLOREANA): S-side, bare lava talus, on rock, 23-Apr-1976, Weber, W.A. s.n. (L-62781, COLO 294739). PINTA: along the trail up to the summit from the S-coast, $0^{\circ} 33^{\prime} 46^{\prime \prime} \mathrm{N}, 90^{\circ} 44^{\prime} 46^{\prime \prime} \mathrm{W}$, $174 \mathrm{~m}$ alt., transition zone, old SW-exposed lava flow in open woodland with Bursera graveolens, Croton scouleri, Opuntia galapageia, few Pisonia floribunda, and with Scalesia baurii in the understory, on rock, 28-Feb-2007, Bungartz, F. 5981 (CDS 33659); at the S-coast, a little E of Cabo Chalmers, $0^{\circ} 33^{\prime} 2^{\prime \prime} \mathrm{N}, 90^{\circ} 46^{\prime} 3^{\prime \prime} \mathrm{W}, 10 \mathrm{~m}$ alt., dry zone, old lava flow with scarce vegetation (Opuntia galapageia, Alternanthera filifolia, Prosopis juliflora), on rock, 01-Mar-2007, Bungartz, F. 6062 (CDS 33741). SANTA FÉ: on top of lava flow at the N-coast of the island, $0^{\circ} 48^{\prime} 12^{\prime \prime} \mathrm{S}, 90^{\circ} 2^{\prime} 34^{\prime \prime} \mathrm{W}, 13 \mathrm{~m}$ alt., coastal zone, open scrubland of partly dead shrubs (Croton scouleri, Cordia lutea), few shrubby Bursera graveolens, and Opuntia echios var. barringtonensis among lava rocks, on rock, 25-Oct-2007, Bungartz, F. 7141 (CDS 37625). SAN CRISTÓBAL: slope of Cerro Tortuga, $4 \mathrm{~km}$ inland from the NW-coast, $0^{\circ} 44^{\prime} 51^{\prime \prime} \mathrm{S}$, $89^{\circ} 23^{\prime} 25^{\prime \prime} \mathrm{W}, 155 \mathrm{~m}$ alt., dry zone, rocky S-exposed slope with few Bursera graveolens, Piscidia carthagenensis, Zanthoxylum fagara, and Mentzelia aspera in the understory, on rock, 25-Apr2007, Bungartz, F. 6567 (CDS 34785). SANTIAGO: at the W-coast of the island in Bahía Ladilla, $0^{\circ} 18^{\prime} 8^{\prime \prime} \mathrm{S}, 90^{\circ} 49^{\prime} 56^{\prime \prime} \mathrm{W}$, $10 \mathrm{~m}$ alt., coastal zone, S-exposed coastal lava cliff and boulders, on rock, 22-Jul-2006, Bungartz, F. 5380 (CDS 29596); Bungartz, F. 5407 (CDS 29623); SE of James Bay, 0¹6'45"S, $90^{\circ} 50^{\prime} 0^{\prime \prime} \mathrm{W}, 40 \mathrm{~m}$ alt., dry zone, open Bursera forest on a lava flow, on rock, 26-Apr-1971, Pike, L.H. 2584 (OSC 53250); near James Bay, $0^{\circ} 14^{\prime} 0^{\prime \prime} \mathrm{S}, 90^{\circ} 49^{\prime} 30^{\prime \prime} \mathrm{W}, 45 \mathrm{~m}$ alt., dry zone, nearly barren, recent, pahoehoe lava flow, on rock, 27-Apr-1971, Pike, L.H. 2596 (OSC 53245); $0^{\circ} 13^{\prime} 50^{\prime \prime} \mathrm{S}, 90^{\circ} 50^{\prime} 50^{\prime \prime} \mathrm{W}, 15 \mathrm{~m}$ alt., dry zone, open Bursera forest on S-facing slope of red cinder cone next to sea and nearly surrounded by recent lava flow, on rock, 28-Apr-1971, Pike, L.H. 2666 (L-56486, COLO 260269); Pike, L.H. 2666 (OSC 53499).

Teloschistes Norman, Conat. Praem. Gen. Lich.: 17. 1852 MycoBank MB 5369

Teloschistes chrysophthalmus (L.) Th. Fr., Syn. N. Amer. Lich. (Boston) 1: 48. 1882.

\section{MycoBank MB 406786}

Basionym: Lichen chrysophthalmus L. [as 'chrysophtalmos'], Mantissa Altera: 311. 1771; MycoBank MB 393845.

Description. Thallus subfruticose to \pm fruticose, overall color typically yellow to deep orange (distinctly gray specimens not known from the Galapagos), in small, erect to \pm prostrate tufts, overall $1-2(-4) \mathrm{cm}$ in diam., growing from a single holdfast, but occasionally attached also by rhizines; branches rigid, up to $0.5 \mathrm{~mm}$ broad, irregular to at least in parts distinctly flattened and then dorsiventral, i.e., with an upper, more deeply orange and a lower, pale yellow side, in parts even grayish or white; cortex on both sides generally dull or barely shiny, typically with sparse cortical hairs; upper surface longitudinally rigged or wrinkled, the lower surface veined by longitudinal cracks, exposing strands of medullary hyphae; overall branching pattern irregular, apices frequently turning upwards and typically ciliate, cilia occasionally also forming alongside the branches and occasionally then attached to the substrate as 'rhizines'; soralia, if present, with farinose to granular soredia, generally very rare and not yet observed in any of the Galapagos specimens. Apothecia typically abundant, developing mostly at the tip, rarely also along the side of the branches, sessile to barely stalked, $(1-) 2-5(-7) \mathrm{mm}$ in diam., generally variable in size, the larger ones typically \pm undulate, lecanorine; thalline margin \pm crenulate and with few to numerous, short to elongate cilia, typically paler than the disc, concolorous with the thallus; disc deeply orange, epruinose, epihymenium with brownish to orange pigment granules, $\mathrm{C}-, \mathrm{K}+$ purple, contiguous with the outer exciple; hymenium hyaline, not inspersed; proper exciple indistinct (almost completely reduced); thalline exciple differentiated into a hyaline inner part, a central part abundantly filled with green algae, lacking crystals, and an outer part with brownish to orange pigment granules, $\mathrm{C}-, \mathrm{K}+$ purple; subhymenium and hypothecium poorly differentiated, hyaline, 
not inspersed; asci clavate, Teloschistes-type; ascospores 8/ascus, polaribilocular, oblong to narrowly ellipsoid, $(11.5-) 13.2-16.5(-17.0) \times(4.0-) 5.2-6.8(-7.2) \mu \mathrm{m}$, with a distinctly broadened, (4.3-)5.3-6.0(-6.9) $\mu \mathrm{m}$ wide septum $(\mathrm{n}=40)$. Pycnidia not observed.

Chemistry. Thallus and apothecia $\mathrm{P}-, \mathrm{K}+$ purple, $\mathrm{C}-$, $\mathrm{KC} \pm$ purplish (fading), UV- (dull); with a large proportion of parietin and smaller proportions of teloschistin, fallacinal, parietinic acid, emodin and erythroglaucin (chemosyndrome A sensu Søchting 1997).

Ecology and distribution. Almost cosmopolitan (though absent from most of Asia, see Frödén et al. 2004), but it is a rare species in the Galapagos, currently known only from dry and transition zone vegetation of Isabela (Volcán Alcedo, Cerro Azul, and Volcán Darwin). It grows on branches and twigs, most commonly found on Zanthoxylum fagara, less frequently also on Croton scouleri, Acacia rorundiana, or Pisonia floribunda.
Notes. The two species of Teloschistes in Galapagos are normally distinguished quite easily; T. chrysophthalmus being abundantly fertile, T. flavicans abundantly sorediate. Generally both species can, however, produce apothecia, as well as soredia. Nevertheless, among all Galapagos specimens of $T$. flavicans, only a single one was found fertile (Bungartz, F. 8541, CDS 41187). The species is very common, particularly throughout the transition zone of the islands. In comparison, T. chrysophthalmus is rare and specimens with soredia have not been found so far anywhere in the archipelago. Cilia of T. flavicans are frequently blackened at their apex while, unless infected by parasites, cilia of T. chrysophthalmus remain deep orange. Branches of $T$. flavicans generally appear more irregularly terete, their lower cortex remaining largely intact, apart from the areas where soralia are being formed. Branches of $T$. chrysophthalmus are at least in part distinctly flattened, the lower side at least in part pale yellow or even whitish gray, the surface typically longitudinally cracked with strands of the medulla exposed.
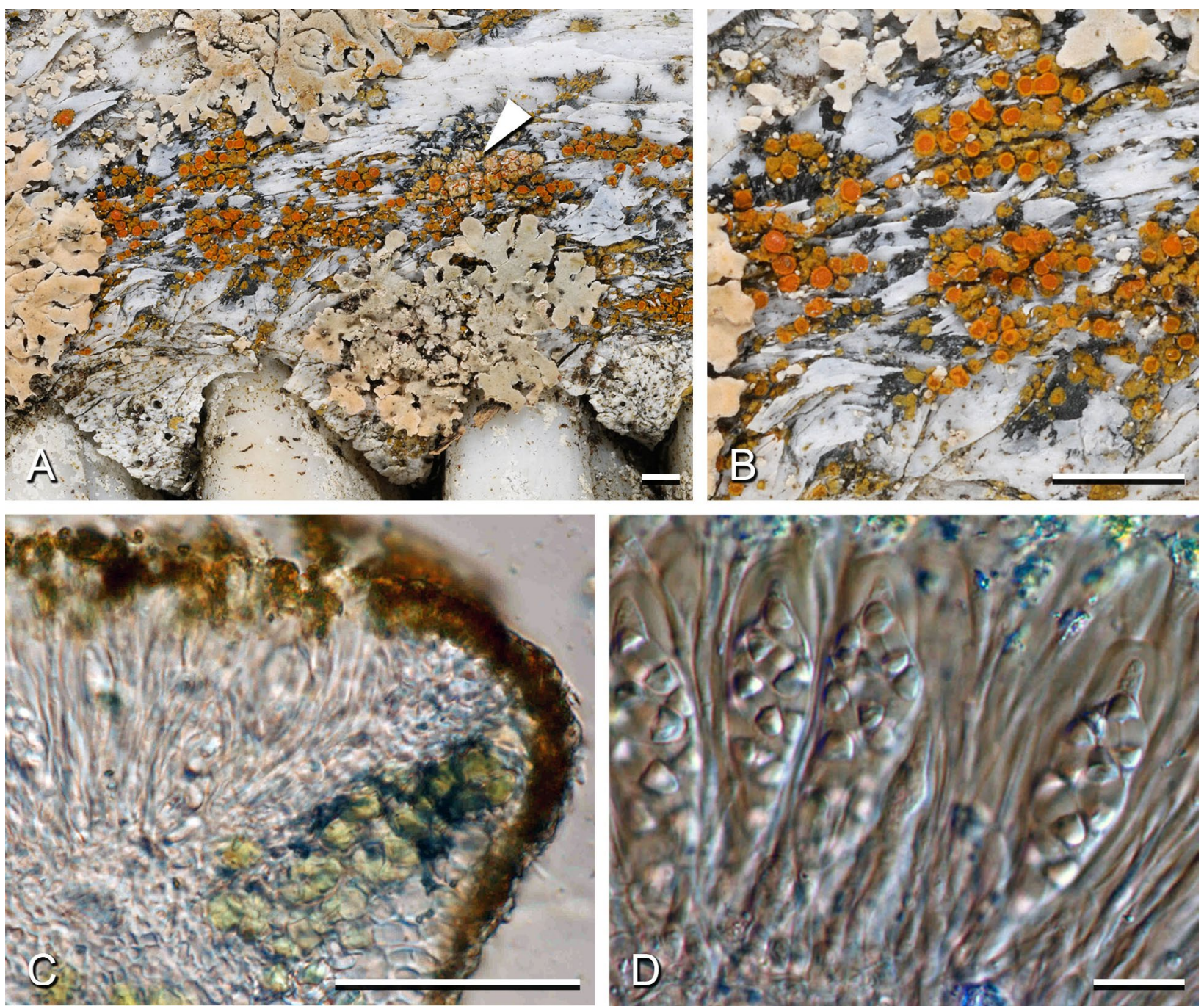

Figure 15. Squamulea osseophila. A - Scattered thallus areoles of S. osseophila (Aptroot, A. 65488 A-holotype) growing in between immature rosettes of Physcia atrostriata on the calciferous lower jawbone of a goat [teeth of the jawbone barely visible in the lower half of the picture]; a minute thallus of $S$. humboldtiana with convex pruinose areoles also visible (arrow: Aptroot, A. 65488 B); B - Close-up of S. osseophila, deep yellow thalli of scattered, convex, 'waxy', epruinose areoles, apothecia sessile, epruinose, the margin concolorous with the thallus, the disc a deeper orange (Aptroot, A. 65488 A, CDS 42936). C-D - apothecial section [DIC, in water] (Aptroot, A. 65489, CDS 32078-holotype). C - Lecanorine, outer thalline exciple densely filled with orange granules, central part with trebouxioid algae, epihymenium with abundant orange granules; D Asci with ellipsoid ascospores, septum broad. Scales: A-B $=2 \mathrm{~mm} ; \mathrm{C}=50 \mu \mathrm{m} ; \mathrm{D}=10 \mu \mathrm{m}$. 
Specimens examined from Ecuador, Galápagos. ISABELA, VOLCÁN ALCEDO: along the trail going up the E-slope, basalt rubble field to the SE-side of the trail and the barranco, $0^{\circ} 24^{\prime} 6^{\prime \prime} \mathrm{S}, 91^{\circ} 2^{\prime} 53^{\prime \prime} \mathrm{W}, 530 \mathrm{~m}$ alt., dry zone, basalt rubble field with scattered vegetation (Bursera graveolens, Zanthoxylum fagara, Pisonia floribunda, Senna pistaciifolia), on bark, 10-Mar-2006, Aptroot, A. 64902 (CDS 31480); along both sides of the trail going up the E-slope, at the NW-side of the barranco, $0^{\circ} 24^{\prime} 5^{\prime \prime} \mathrm{S}, 91^{\circ} 2^{\prime} 53^{\prime \prime} \mathrm{W}, 480 \mathrm{~m}$ alt., dry zone, open Bursera graveolens stand, with an occasional Pisonia floribunda, and Zanthoxylum fagara in between and shrubs of Macraea laricifolia, Waltheria ovata, and Senna pistaciifolia, on bark, 10-Mar-2006, Bungartz, F. 4422 (CDS 28507). VOLCÁN CERRO AZUL: path from the first Caseta del Parque to Caleta Iguana at the coast, approx. one third of the way, $0^{\circ} 59^{\prime} 9^{\prime \prime} \mathrm{S}, 91^{\circ} 26^{\prime} 4^{\prime \prime} \mathrm{W}, 224 \mathrm{~m}$ alt., transition zone, dense Psidium guajava woodland with few large Zanthoxylum fagara trees, Pisonia floribunda and Scalesia cordata trees, understory with Tournefortia rufo-sericea shrubs and ferns, on bark, 08-May-2012, Spielmann, A.A. 10679 (CDS 52034), 10680 (CDS 52035), 10681 (CDS 52036); Bungartz, F. 10422 (CDS 52391). VOLCÁN DARWIN: southwestern slope, above Tagus Cove, $0^{\circ} 14^{\prime} 15^{\prime \prime} \mathrm{S}, 91^{\circ} 20^{\prime} 40^{\prime \prime} \mathrm{W}$, $351 \mathrm{~m}$ alt., dry zone, open Bursera graveolens forest with Croton scouleri, Macraea laricifolia and Waltheria ovata, few trees of Acacia rorudiana, on bark, 16-Nov-2007, Ertz, D. 12017 (CDS 37376); 0¹3'57"S, 91²0'5.096"W, 613 m alt., transition zone, SW-exposed lava flow of weathered AA-lava with scarce vegetation (Macraea laricifolia, Croton scouleri, Dodonaea viscosa, Scalesia microcephala, Cordia revoluta and Opuntia insularis), on bark, 12-Nov-2007, Bungartz, F. 7405 (CDS 37892). VOLCÁN SIERRA NEGRA: Volcán Santo Tomás, cerca del borde del cráter, $0^{\circ} 50^{\prime} 0^{\prime \prime} \mathrm{S}, 91^{\circ} 2^{\prime} 0^{\prime \prime} \mathrm{W}$, $\mathrm{m}$ alt., arbustos, 01-Feb-1994, Follmann, G. 35311 (108732, B-KOELN 60 0173569).

Teloschistes flavicans (Sw.) Norman, Nytt Mag. Natur. 7: 229. 1853 [1852]. (Fig. 18B-C)

MycoBank MB 355609

Basionym: Lichen flavicans Sw., Prodr.: 147. 1788; MycoBank MB 462958.

Description. Thallus fruticose, overall color typically deep yellow to almost reddish orange, in small erect tufts or relatively large clusters of loosely entangled branches, overall 1.5-5(-10) cm in diam.; branches \pm flexible, up to $1.5 \mathrm{~mm}$ wide, irregularly terete, not distinctly flattened, not dorsiventral, typically at least apically ciliate, occasionally also with sparse cilia along the side; cilia often blackened at their tip; cortex dull, with sparse to abundant cortical hairs, rarely \pm tomentose, surface irregularly wrinkled, but not cracked (apart from the areas where soralia are formed); overall branching pattern \pm dichotomous, apices straight to irregularly curved; soralia common, typically abundant, initially punctiform, then orbicular, but soon broadened to elongate, typically developing along the side of the branches and occasionally confluent, with pale to deep yellow, farinose to \pm granular soredia, which are rarely budding into short cilia or even secondary branches, but more typically erode, leaving \pm labriform scars. Apothecia very rare (found in one Galapagos specimen only), developing along the side of the branches, sessile to barely stalked, (0.6-)1-3(-4) $\mathrm{mm}$ in diam., \pm undulate; lecanorine; thalline margin entire to \pm undulate, regularly circular, densely sorediate, occasionally with sparse, short cilia; disc deeply orange, epruinose; epihymenium with brownish to orange pigment granules, $\mathrm{C}-$-, $\mathrm{K}+$ purple, contiguous with the outer exciple; hymenium hyaline, not inspersed; proper exciple indistinct (almost completely reduced); thalline exciple differentiated into a hyaline inner part, a central part abundantly filled with photobionts, lacking crystals, and an outer part with brownish to orange pigment granules, $\mathrm{C}-, \mathrm{K}+$ purple; subhymenium and hypothecium poorly differentiated, hyaline, not inspersed; asci clavate, Teloschistes-type; ascospores 8/ascus, polaribilocular, oblong to narrowly ellipsoid, (9.5-)11.3-17.8(-20.3) × (5.0-)6.0-8.5(-9.5) $\mu \mathrm{m}$, with a distinctly broadened, $(3.3-) 3.5-8.6(-11.0) \mu \mathrm{m}$ wide septum $(\mathrm{n}=39)$. Pycnidia not observed.

Chemistry. Thallus and apothecia $\mathrm{P}-, \mathrm{K}+$ purple, $\mathrm{C}-$, $\mathrm{KC} \pm$ purplish (fading), UV- (dull); contains high proportions of parietin and caloploicin, lesser proportions of teloschistin, fallacinal, parietinic acid, vicanicin and isofulgidin, occasionally also with emodin (chemosyndrome A+2 sensu Søchting \& Frödén 2002). This is the same syndrome as found in T. flavicans in S. America (Søchting \& Frödén 2002).

Ecology and distribution. Widespread throughout the tropics and subtropics (Frödén et al. 2004) and in Galapagos extremely common. It is very characteristic of the lower, but still fog-drenched parts of the transition zone, among curtains of Ramalina usnea, $R$. anceps and Usnea mexicana, though best developed in habitats that are slightly drier, where the Ramalina and Usnea species are not dominant. Small thalli are typically found also in the dry zone further below and rarely even directly at the coast. The species is generally less abundant but still regularly present also in the humid zone. It typically grows on bark, but occasionally it can be found on cacti or even stems of herbaceous plants, and rarely also on rock.

Notes. Diagnostic differences of T. chrysophtalmus are discussed there.

Specimens examined from Ecuador, Galápagos. ISABELA, VOLCÁN ALCEDO: along the trail going up the E-slope, at the NW-side of the trail, $0^{\circ} 24^{\prime} 2^{\prime \prime} \mathrm{S}, 91^{\circ} 2^{\prime} 36^{\prime \prime} \mathrm{W}, 410 \mathrm{~m}$ alt., dry zone, basalt boulders and outcrops at the NW-exposed slope of the barranco, Bursera graveolens and Zanthoxylum fagara growing in between, on bark, 09-Mar-2006, Bungartz, F. 4389 (CDS 28474 ); on the crater rim near the hut, $0^{\circ} 26^{\prime} 33^{\prime \prime} \mathrm{S}, 91^{\circ} 5^{\prime} 31^{\prime \prime} \mathrm{W}$, $1100 \mathrm{~m}$ alt., humid zone, Pteridium arachnoideum and Stachytarpheta cayennensis, scattered low shrubs of Tournefortia rufo-sericea and outcrops of basalt tuff in between, on bark, 07-Mar-2006, Aptroot, A. 65217 (CDS 31803), 65278 (CDS 31864); rim of caldera of Volcán Alcedo, $700 \mathrm{~m}$ alt., humid zone, on bark, 11-May-1976, Weber, W.A. s.n. (L-63295, COLO 297126); outer SE-exposed slope and crater rim, 0²7'29"S, $91^{\circ} 7^{\prime} 19^{\prime \prime} \mathrm{W}, 1089 \mathrm{~m}$ alt., humid zone, disturbed by former grazing of goats therefore scattered trees (Tournefortia rufo-sericea, Zanthoxylum fagara), on bark, 05-Mar-2006, Bungartz, F. 4027 (CDS 27957); cerca las fumarolas, $0^{\circ} 26^{\prime} 22^{\prime \prime} \mathrm{S}, 91^{\circ} 8^{\prime} 35^{\prime \prime} \mathrm{W}, 900 \mathrm{~m}$ alt., zona de transición, con árboles de Trema micrantha, con 

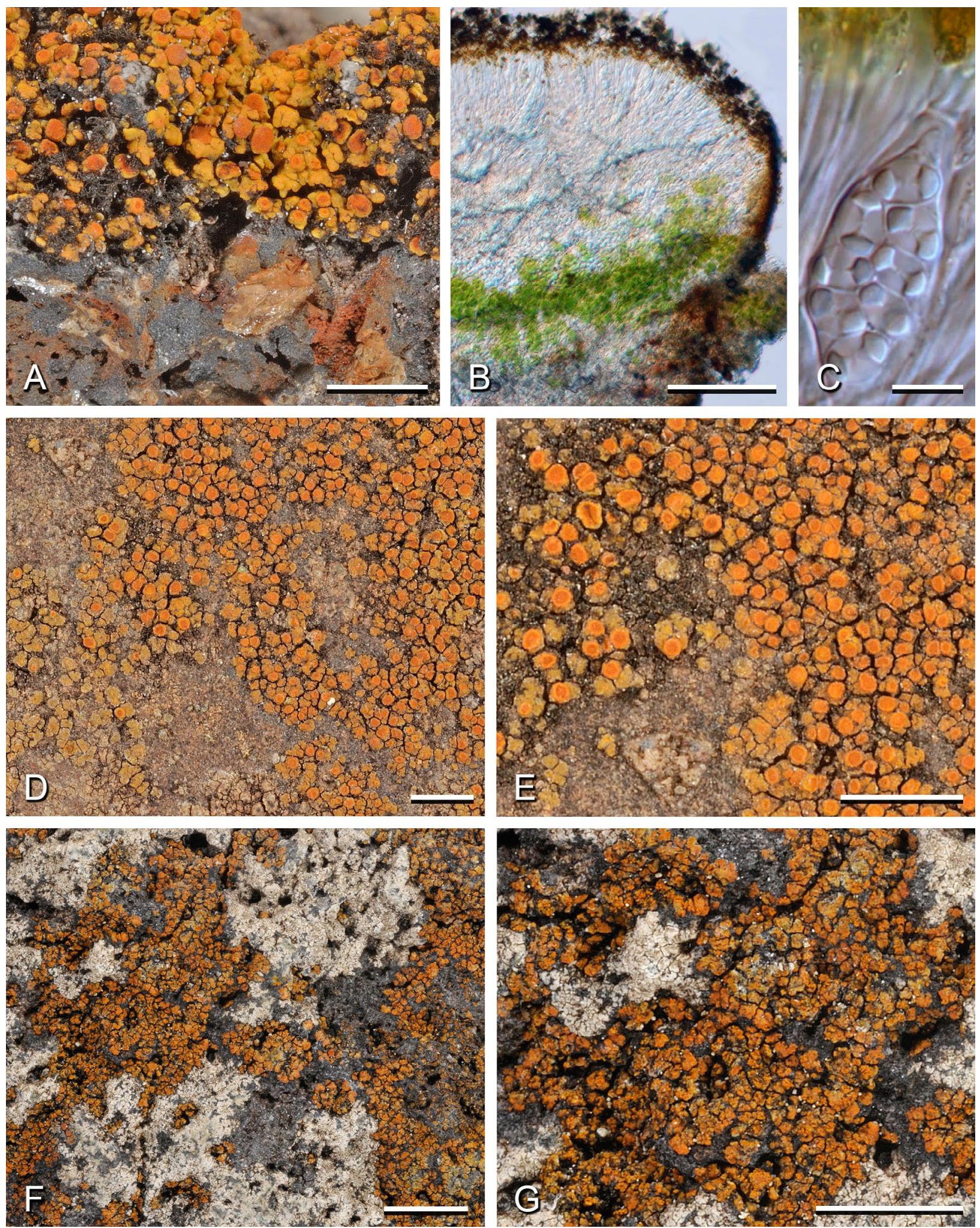

Figure 16. Squamulea subsoluta/squamosa s.l. A-C - Squamulea aff. squamosa. A - Morphotype phylogenetically close to S. squamosa s.str., with a distinctly squamulose deep yellow-orange, epruinose thallus; apothecia sessile, epruinose, their margin concolorous with the thallus, the disc more deeply orange. (Bungartz, F. 7428, CDS 37915); B - Apothecial section: outer thalline exciple and epihymenium densely filled with orange granules, inner exciple hyaline, hypothecium hyaline, paraplectenchymatous, of large, \pm rounded cells, trebouxioid green algae radiating into the inner exciple from below the hypothecium [DIC, in water] (Bungartz, F. 7428, CDS 37915); C - Broadly clavate ascus with broad, ellipsoid ascospores, septum moderately widened [DIC, in water] (Aptroot, A. 64940, CDS 31519). D-E - Squamulea subsoluta s.l. (Aptroot, A. 65480, CDS 32069, specimen close to the Squamulea loekoesiana-clade). D - Scattered to closely aggregated, epruinose, deep yellow-orange, angular to barely subsquamulose areoles with adnate apothecia; E - Close-up with isolated, more scattered areoles becoming barely subsquamulose, central, adjoining areoles angular, not subsquamulose; apothecia and thallus epruinose, disc only slightly deeper in color than the thallus. F-G - Sorediate morphotype of Squamulea subsoluta/squamosa s.1. (Weber, W.A. s.n. \& Lanier, J., L-62891, COLO 294630). F - Overview of thallus growing in between a sterile specimen of Sucioplaca diplacia; $\mathrm{G}$ - Close-up of deep orange, epruinose, subsquamulose areoles, along their edges breaking into ill-defined soralia with coarse soredia. Scales: $A, D-G=2 \mu m ; B=100 \mu \mathrm{m} ; C=10 \mu \mathrm{m}$. 
muy poca vegetación, los árboles existentes carecen de hojas, es una zona casi sin vida, sobre corteza, 01-Dec-2006, Nugra, F. 159 (CDS 32813); al lado este del cumbre, $0^{\circ} 26^{\prime} 54^{\prime \prime} \mathrm{S}$, $91^{\circ} 5^{\prime} 22^{\prime \prime} \mathrm{W}, 950 \mathrm{~m}$ alt., zona húmeda, bosque abierto, sobre corteza, 30-Dec-2006, Nugra, F. 170 B (CDS 38753). VOLCÁN CERRO AZUL: along the trail from Caleta Iguana to the first Caseta del Parque, $0^{\circ} 59^{\prime} 13^{\prime \prime} \mathrm{S}, 9^{\circ}{ }^{\circ} 5^{\prime} 39^{\prime \prime} \mathrm{W}, 300 \mathrm{~m}$ alt., transition zone, open Psidium guajava forest, with Zanthoxylum fagara, Tournefortia rufo-sericea, and Darwiniothamnus lancifolius, on bark, 02-May-2012, Nugra, F. 1007 (CDS 52170); lower crater slopes above the first Caseta del Parque; below the cloud layer, $0^{\circ} 58^{\prime} 39^{\prime \prime} \mathrm{S}, 91^{\circ} 25^{\prime} 25^{\prime \prime} \mathrm{W}, 434 \mathrm{~m}$ alt., transition zone, open Guajava forest, with sparse Psidium guajava shrubs, few larger Zanthoxylum fagara trees, and Tournefortia rufo-sericea scrub, on bark, 03-May-2012, Spielmann, A.A. 10431 (CDS 51786), 10432 (CDS 51788); uppermost crater slopes of blackened volcanic ash fields along the crater rim, $0^{\circ} 56^{\prime} 20^{\prime \prime} \mathrm{S}, 91^{\circ} 24^{\prime} 13^{\prime \prime} \mathrm{W}$, $1614 \mathrm{~m}$ alt., high-altitude dry zone, open black volcanic ash fields bare of vegetation with inspersed patches of vegetation of (Opuntia spp.), very few Tournefortia rufo-sericea shrubs and occasional Iochroma ellipticum trees, on bark, 05-May2012, Spielmann, A.A. 10486 (CDS 51842). VOLCÁN DARWIN: southwestern slope, above Tagus Cove (2nd campsite), $0^{\circ} 13^{\prime} 43^{\prime \prime} \mathrm{S}, 91^{\circ} 19^{\prime} 47^{\prime \prime} \mathrm{W}, 724 \mathrm{~m}$ alt., transition zone, SW-exposed lava flow of weathered AA-lava with scarce vegetation (Macraea laricifolia, Dodonaea viscosa, Croton scouleri, Cordia revoluta and Jasminocereus thouarsii), on bark, 12-Nov-2007, Bungartz, F. 7478 (CDS 37965); southwestern crater rim, $0^{\circ} 12^{\prime} 11^{\prime \prime} \mathrm{S}$, $91^{\circ} 18^{\prime} 41^{\prime \prime} \mathrm{W}, 1286 \mathrm{~m}$ alt., high-altitude dry zone, open forest of Scalesia microcephala, few trees of Zanthoxylum fagara, Cordia revoluta and Croton scouleri shrubs, many young Scalesia in the understory, on bark, 13-Nov-2007, Bungartz, F. 7525 (CDS 38016); southwestern slope, above Tagus Cove, $0^{\circ} 13^{\prime} 27^{\prime \prime} \mathrm{S}$, $91^{\circ} 19^{\prime} 21^{\prime \prime} \mathrm{W}, 860 \mathrm{~m}$ alt., transition zone, open scrubland of Dodonaea viscosa, Croton scouleri, Macraea laricifolia, Scalesia microcephala, few Opuntia insularis and dry grasses in the understory, on bark, 15-Nov-2007, Bungartz, F. 7685 (CDS 38188); $0^{\circ} 13^{\prime} 59^{\prime \prime} \mathrm{S}, 91^{\circ} 20^{\prime} 8^{\prime \prime} \mathrm{W}, 597 \mathrm{~m}$ alt., dry zone, open Bursera graveolens forest with Croton scouleri and Macraea laricifolia shrubs, few Chiococca alba and Scalesia microcephala, among lava boulders and outcrops, on bark, 16-Nov-2007, Bungartz, F. 7861 (CDS 38370). VOLCÁN SIERRA NEGRA: along dirt road from Puerto Villamil to crater of Sierra Negra, $0^{\circ} 55^{\prime} 12^{\prime \prime} \mathrm{S}, 90^{\circ} 59^{\prime} 38^{\prime \prime} \mathrm{W}, 30 \mathrm{~m}$ alt., dry zone, top of old lava flow with scattered vegetation (Bursera graveolens, Opuntia echios, and Waltheria ovata), on bark, 10-Sep-2007, Bungartz, F. 6997 (CDS 36501), 6949 (CDS 36453); close to La Esperanza, $0^{\circ} 51^{\prime} 37^{\prime \prime} \mathrm{S}, 91^{\circ} 1^{\prime} 40^{\prime \prime} \mathrm{W}, 306 \mathrm{~m}$ alt., humid zone, farming areas, slope $20^{\circ} \mathrm{SE}$, on bark, 15-Aug-2008, Herrera-Campos, M.A.

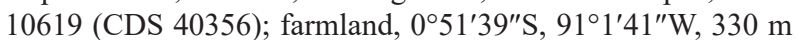
alt., humid zone, Cedrela odorata and Psidium guajava trees along road bordering a pasture, on bark, 09-Sep-2007, Bungartz, F. $6926(\mathrm{CDS} 36425) ; 0^{\circ} 51^{\prime} 32^{\prime \prime} \mathrm{S}, 91^{\circ} 1^{\prime} 50^{\prime \prime} \mathrm{W}, 346 \mathrm{~m}$ alt., humid zone, Cedrela odorata and Psidium guajava trees along road bordering a pasture, on plant stems, 09-Sep-2007, Bungartz, F. 6917 (CDS 36415); near parking place at start of foot path to the crater, $0^{\circ} 49^{\prime} 47^{\prime \prime} \mathrm{S}, 91^{\circ} 5^{\prime} 19^{\prime \prime} \mathrm{W}, 939 \mathrm{~m}$ alt., humid zone, open grazed woodland of shrubby Psidium guajava, on bark, 08-Sep2007, Bungartz, F. 6832 (CDS 36263); mirador El Mango, SE side of island, $0^{\circ} 53^{\prime} 1.399^{\prime \prime} \mathrm{S}, 91^{\circ} 0^{\prime} 48^{\prime \prime} \mathrm{W}, 161 \mathrm{~m}$ alt., transition zone, rocky area (open) with shrubs of Psidium guajava, ferns and Stereocaulon covering the ground, on bark, 15-Aug-2008, Truong, C. 1235 (CDS 39546); Herrera-Campos, M.A. 10584 (CDS 40321); on leaves, 15-Aug-2008, Herrera-Campos, M.A. 10586 (CDS 40323); on the E-side of the dirt road, $0^{\circ} 53^{\prime} 1^{\prime \prime} \mathrm{S}$, $91^{\circ} 0^{\prime} 50^{\prime \prime} \mathrm{W}, 162 \mathrm{~m}$ alt., transition zone, lower transition zone; basalt lava outcrop with scattered vegetation (Polypodium sp., Pityrogramma calomelanos, Darwiniothamnus tenuifolia), on plant stems \& leaves, 15-Aug-2008, Bungartz, F. 8200 (CDS 40846); around the mirador El Mango, $0^{\circ} 53^{\prime} 2^{\prime \prime} \mathrm{S}, 91^{\circ} 0^{\prime} 51^{\prime \prime} \mathrm{W}$, $174 \mathrm{~m}$ alt., transition zone, mixed stand with Cedrela odorata and Kalanchoe pinnata invading the understory, slope $15^{\circ} \mathrm{SE}$, on bark, 15-Aug-2008, Herrera-Campos, M.A. 10670 (CDS 40407), 10672 (CDS 40409); Muro de las Lagrimas, $25 \mathrm{~km}$ $\mathrm{W}$ of Puerto Villamil, $0^{\circ} 57^{\prime} 52^{\prime \prime} \mathrm{S}, 91^{\circ} 0^{\prime} 46^{\prime \prime} \mathrm{W}, 78 \mathrm{~m}$ alt., dry zone, wall of basalt boulders, SE-exposed, on bark, 17-Aug2008, Bungartz, F. 8446 (CDS 41092); small hill above the wall, $0^{\circ} 57^{\prime} 54^{\prime \prime} \mathrm{S}, 91^{\circ} 0^{\prime} 47^{\prime \prime} \mathrm{W}, 81 \mathrm{~m}$ alt., dry zone, dry zone vegetation with Bursera graveolens and Opuntia echios, slope $45^{\circ}$ N, on bark, 17-Aug-2008, Truong, C. 1294 (CDS 39605); along the stairs going up behind the wall, $0^{\circ} 57^{\prime} 52^{\prime \prime} \mathrm{S}, 91^{\circ} 0^{\prime} 46^{\prime \prime} \mathrm{W}, 78 \mathrm{~m}$ alt., dry zone, dry zone vegetation with Bursera graveolens and Opuntia echios, slope $45^{\circ} \mathrm{N}$, on bark, 17-Aug-2008, HerreraCampos, M.A. 10739 (CDS 40477); Volcán Santo Tomás, borde del cráter, $0^{\circ} 50^{\prime} 0^{\prime \prime} \mathrm{S}, 91^{\circ} 2^{\prime} 0^{\prime \prime} \mathrm{W}$, m alt., 01-Feb-1994, Follmann, G. 34989 (108733, B-KOELN 60 0173574). VOLCÁN WOLF: Iguana Cove, on bark, Snodgrass, R.E. s.n. (FH 197414), s.n. (CAS-DS 681269). SAN CRISTÓBAL: Southwest end, upper region, Baur, G. s.n. (FH 197413); sector of the 'Gotera de agua', trail to Cerro Pelado, $0^{\circ} 51^{\prime} 51^{\prime \prime} \mathrm{S}, 89^{\circ} 27^{\prime} 36^{\prime \prime} \mathrm{W}, 402 \mathrm{~m}$ alt., transition zone, upper transition zone, open area within the forest with shrubs of Psidium guajava and Macraea laricifolia, and Malachra capitata covering the ground, flat plane, on bark, 23-Aug-2008, Truong, C. 1496 (CDS 39807); Herrera-Campos, M.A. GAL-422 (CDS 43313), M.A. 10902 (CDS 43438); $0^{\circ} 51^{\prime} 40^{\prime \prime} \mathrm{S}, 89^{\circ} 27^{\prime} 37^{\prime \prime} \mathrm{W}, 397 \mathrm{~m}$ alt., transition zone, upper transition zone, forest stand with Psidium guajava, Hippomane mancinella, Macraea laricifolia and Rubus niveus invading the understory, slope $15^{\circ} \mathrm{SE}$, on bark, 23-Aug-2008, Herrera-Campos, M.A. GAL-435 (CDS 43326); northwestern foothills of Media Luna, inland from the NW-coast, $0^{\circ} 43^{\prime} 41^{\prime \prime} \mathrm{S}, 89^{\circ} 18^{\prime} 44^{\prime \prime} \mathrm{W}$, $75 \mathrm{~m}$ alt., dry zone, open woodland of Cordia lutea and Bursera graveolens, on bark, 22-Apr-2007, Bungartz, F. 6189 (CDS 34401); southwestern foothills of Media Luna, inland from the NW-coast of the island along the trail from Galapagera to Media Luna; bottom of small crater to the NW of Media Luna, $0^{\circ} 43^{\prime} 53^{\prime \prime} \mathrm{S}, 89^{\circ} 18^{\prime} 57^{\prime \prime} \mathrm{W}, 124 \mathrm{~m}$ alt., dry zone, upper dry zone; woodland of Piscidia carthagenensis, Cordia lutea, Zanthoxylum fagara, Croton scouleri and few Bursera graveolens, on bark, 22-Apr-2007, Bungartz, F. 6273 (CDS 34485); saddle between the two summits of Cerro Tortuga, $0^{\circ} 44^{\prime} 52^{\prime \prime} \mathrm{S}$, $89^{\circ} 23^{\prime} 27^{\prime \prime} \mathrm{W}, 140 \mathrm{~m}$ alt., dry zone, open Piscidia carthagenensis woodland with understory of Cordia lutea, on bark, 25-Apr2007, Bungartz, F. 6558 (CDS 34776); crest of Cerro Tortuga, $\sim 4 \mathrm{~km}$ inland from the NW-coast, $0^{\circ} 44^{\prime} 54^{\prime \prime} \mathrm{S}, 8^{\circ} 23^{\prime} 32^{\prime \prime} \mathrm{W}$, 116 m alt., dry zone, open Piscidia carthagenensis woodland with few Bursera graveolens and dense understory of Croton scouleri, Cordia lutea, and Mentzelia aspera on rocky SE-exposed slope of hill, on bark, 25-Apr-2007, Bungartz, F. 6538 (CDS 34756); Cerro Partido along trail from entrance to Cerro Pelado to El Ripioso, $0^{\circ} 51^{\prime} 23^{\prime \prime} \mathrm{S}, 8^{\circ} 27^{\prime} 37^{\prime \prime} \mathrm{W}, 376 \mathrm{~m}$ alt., transition zone, rocky SW-exposed slope of hill with Jasminocereus thouarsii, Clerodendrum molle var. glabrescens, Psidium galapageium, Bromeliaceae and ferns growing in rock crevices, on cactus, 28-Apr-2007, Bungartz, F. 6601 (CDS 34821), 6616 (CDS 34836); trail from Cerro Pelado to El Ripioso, S of Cerro Partido, $0^{\circ} 51^{\prime} 28^{\prime \prime} \mathrm{S}, 89^{\circ} 27^{\prime} 38^{\prime \prime} \mathrm{W}, 372 \mathrm{~m}$ alt., transition zone, open flat area with the abundant annual herb Malachra capitata and scattered shrubs of Psidium guajava and Croton scouleri, on bark, 23-Aug-2008, Bungartz, F. 8541 (CDS 41187); area $\mathrm{W}$ of Cerro Pelado on the way to El Ripioso, $0^{\circ} 51^{\prime} 50^{\prime \prime} \mathrm{S}$, $89^{\circ} 27^{\prime} 40^{\prime \prime} \mathrm{W}, 400 \mathrm{~m}$ alt., transition zone, open Psidium guajava 
shrubland with Macraea laricifolia and dominant annual herb Malachra capitata, on bark \& wood, 23-Aug-2008, Bungartz, F. 8484 (CDS 41130); bordering lake at El Junco, humid zone, on steep slope bordering lake, on rock, 21-May-1976, Lanier, J. s.n. (L-63760, COLO 298419); Cerro Colorado, enclosure for Calandrinia galapagosa near the viewpoint on the top, $0^{\circ} 54^{\prime} 58^{\prime \prime} \mathrm{S}, 89^{\circ} 26^{\prime} 5^{\prime \prime} \mathrm{W}, 130 \mathrm{~m}$ alt., transition zone, open scrubland with Croton scouleri, Macraea laricifolia, Calandrinia galapagosa, Lecocarpus darwinii and few trees of Piscidia carthagenensis among lava boulders on SE-exposed slope of cinder cone, on bark, 29-Apr-2007, Bungartz, F. 6743 (CDS 34987); Cerro Colorado, fenced-off area, $0^{\circ} 54^{\prime} 58^{\prime \prime} \mathrm{S}, 89^{\circ} 26^{\prime} 4^{\prime \prime} \mathrm{W}$, $132 \mathrm{~m}$ alt., transition zone, on bark, 15-May-2006, Jaramillo, P. 2879 A (CDS 38794), 2880 C (CDS 38798), 2886 C (CDS 38804); Cerro Colorado summit, around the viewpoint, $0^{\circ} 54^{\prime} 54^{\prime \prime} \mathrm{S}, 89^{\circ} 26^{\prime} 1^{\prime \prime} \mathrm{W}, 159 \mathrm{~m}$ alt., dry zone, dry zone vegetation with Croton scouleri, Cordia lutea and Macraea laricifolia, slope $15^{\circ} \mathrm{SWW}$ (on the ridge), on bark, 24-Aug-2008, Herrera-Campos, M.A. GAL-453 (CDS 43344); W of the cemetery of El Progresso at the border of the National Park, $0^{\circ} 54^{\prime} 44^{\prime \prime} \mathrm{S}$, $89^{\circ} 34^{\prime} 34^{\prime \prime} \mathrm{W}, 170 \mathrm{~m}$ alt., transition zone, at the edge of a forest of native and introduced trees (Hippomane mancinella, Tamarindus indica, Leucaena leucocephala, Clerodendrum molle and vines), on bark, 24-Aug-2008, Bungartz, F. 8570 (CDS 41216). SANTA CRUZ: E-slope, $200 \mathrm{~m}$ alt., transition zone, 04-Apr1969, Horneman, S. s.n. (L-67373, COLO 316715); Academy Bay, on bark, 27-Mar-1971, Higgins, A. s.n. (FH 197411); vicinity of Academy Bay, coastal zone, coastal scrub, 15-Feb-1964, Weber, W.A. s.n. (L-41187, COLO 195013); at seismic station, dry zone, 29-Jan-1964, Schuster, R.O. s.n. (L-40124, COLO 189726); base of barranco near seismic station, $20 \mathrm{~m}$ alt., dry zone, on bark, 11-Apr-1976, Weber, W.A. s.n. (CDS 10816), s.n. (QCA); along short trail from Darwin Research Station to seismic station, about $0.4 \mathrm{~km}$ back from the beach, $30 \mathrm{~m}$ alt., dry zone, in cactus forest, on bark, 27-Jan-1964, Weber, W.A. s.n. (FH 197410); Table Mountain (= Cerro Mesa), humid zone, in moist zone, on bark, 15-Feb-1964, Weber, W.A. s.n. (L-41183, COLO 194814); on the cliff behind the tortoise corral of the Charles Darwin Research Station, $0^{\circ} 44^{\prime} 14^{\prime \prime} \mathrm{S}, 90^{\circ} 18^{\prime} 2.399^{\prime \prime} \mathrm{W}$, $36 \mathrm{~m}$ alt., dry zone, dry zone vegetation with Opuntia and Acacia, with the influence of the sea (at $\sim 1 \mathrm{~km}$; presence of salt bush), S-exposed, very little slope, on bark, 03-Aug-2008, Clerc,
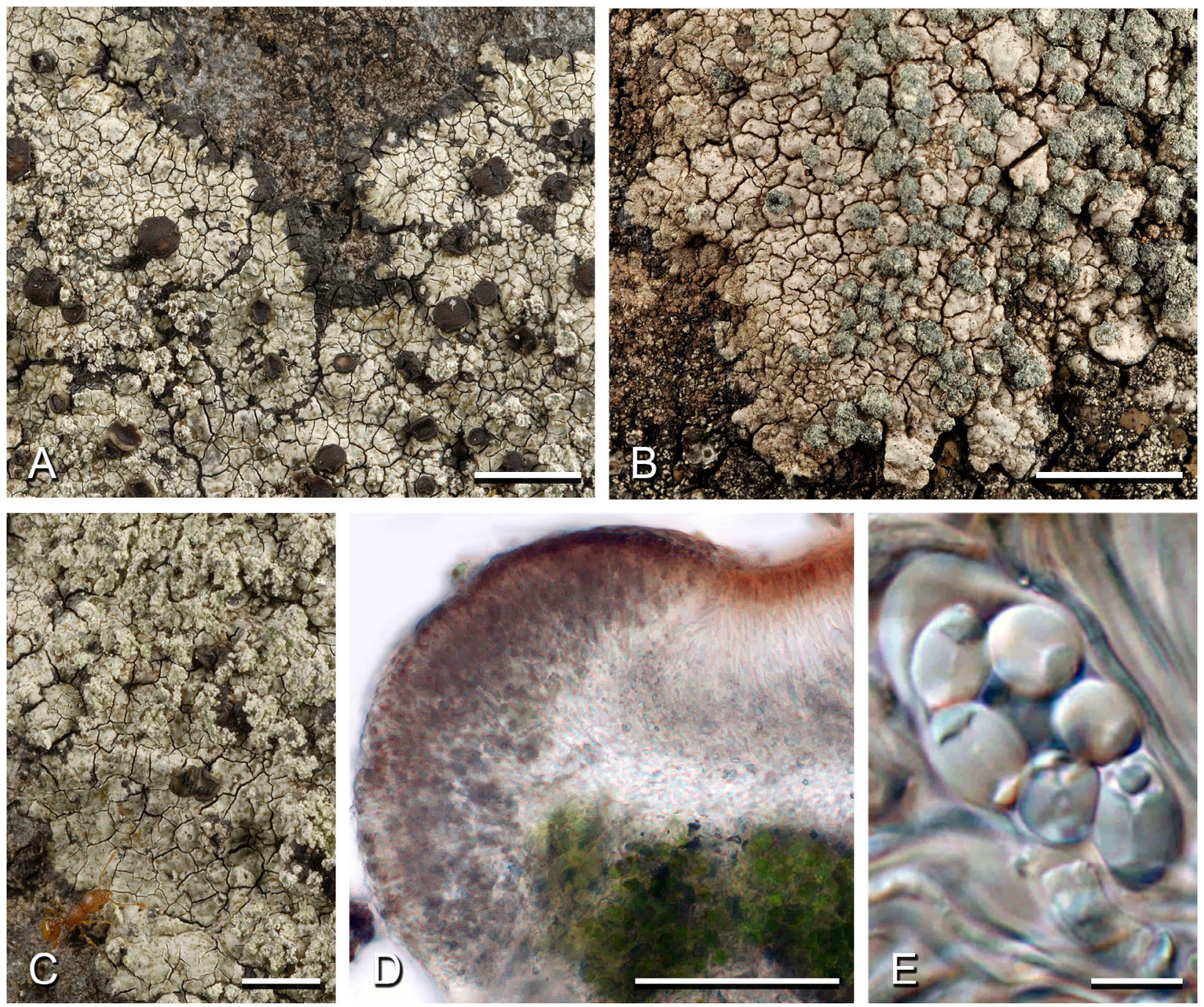

Figure 17. Sucioplaca diplacia. A - Gray, areolate thallus, distinctly delimited by a black prothallus, with few pustulate soralia (grayish white soredia with bluish tinge), apothecia abundant, mostly black throughout, some only discolored in part by a violaceous pigment (Bungartz, F. 5630, CDS 33255); B - Gray, areolate-subsquamulose thallus with abundant pustulate soralia, soredia tinged bluish gray (Bungartz, F. 4815, CDS 28979); C - Thallus with soredia and apothecia, visited by little red fire ant [Wasmannia auropunctata (Roger, 1863)] (Bungartz, F. 5630, CDS 33255); D - Apothecial section: lecanorine, outer thalline exciple colored by a diffuse violaceous pigment, most strongly concentrated at the top, extending, but less concentrated across the epihymenium, inner and lower thalline exciple filled with trebouxioid green algae, innermost thalline exciple hyaline, hypothecium and lateral proper exciple grayish [DIC, in water] (Clerc, P. 08-384, CDS 40238); E - Ascus with broadly ellipsoid to almost globose ascospores, septum very broad (Clerc, P. 08-230, CDS 40084). Scales: A-C = 2 mm; D = $100 \mu \mathrm{m} ; \mathrm{E}=10 \mu \mathrm{m}$. 
P. 08-15 (CDS 39869); Puerto Ayora, near begin of road to Baltra, $0^{\circ} 44^{\prime} 34^{\prime \prime} \mathrm{S}, 90^{\circ} 18^{\prime} 45^{\prime \prime} \mathrm{W}, 25 \mathrm{~m}$ alt., dry zone, on bark, 26-May-2005, Aptroot, A. 63075 (CDS 29803); along the trail from Puerto Ayora to Bahía Tortuga, $0^{\circ} 44^{\prime} 48^{\prime \prime} \mathrm{S}, 90^{\circ} 19^{\prime} 14^{\prime \prime} \mathrm{W}$, $28 \mathrm{~m}$ alt., dry zone, decidous forest in dry zone; with Bursera graveolens, Acacia rorudiana, and Opuntia echios; over basalt, on bark, 05-Jan-2006, Bungartz, F. 3350 (CDS 27017); on the way to Bahía Tortuga, $0^{\circ} 45^{\prime} 0^{\prime \prime} \mathrm{S}, 90^{\circ} 19^{\prime} 0^{\prime \prime} \mathrm{W}$, dry zone, on bark, 16-Feb-1994, Follmann, G. 34978 (108750, B-KOELN 60 0173586); between Bellavista and Puerto Ayora, site 14, on bark, 31-Jul-2000, LeDee, O.E. OEL-00-09 D (CDS 56065); near Los Gemelos craters, $0^{\circ} 36^{\prime} 31^{\prime \prime} \mathrm{S}, 90^{\circ} 22^{\prime} 4^{\prime \prime} \mathrm{W}, 350 \mathrm{~m}$ alt., humid zone, on bark, 28-May-2005, Aptroot, A. 63224 (CDS 29959), 63380 (CDS 30126); along the road from Los Gemelos towards the N-coast of the island, $\sim 1 \mathrm{~km} \mathrm{~N}$ of Los Gemelos, $0^{\circ} 37^{\prime} 22^{\prime \prime} \mathrm{S}, 90^{\circ} 22^{\prime} 47^{\prime \prime} \mathrm{W}, 584 \mathrm{~m}$ alt., transition zone, upper transition zone with open dry forest, Scalesia pedunculata, Chiococca alba, Tournefortia rufo-sericea, Cordia leucophlyctis, and Zanthoxylum fagara, on bark, 12-Feb-2006, Bungartz, F. 3501 (CDS 27279); cerca la vía sector Los Gemelos, $0^{\circ} 38^{\prime} 0.1000^{\prime \prime} \mathrm{S}, 90^{\circ} 23^{\prime} 35^{\prime \prime} \mathrm{W}, 661 \mathrm{~m}$ alt., zona húmeda, bosque de Scalesia pedunculata, sobre corteza, 15-Feb-2007, Nugra, F. 399 (CDS 35154); above the quarry Mina Granillo Rojo, off the main road to the channel, on the $\mathrm{N}$-side of the island, $0^{\circ} 37^{\prime} 5.798^{\prime \prime} \mathrm{S}, 90^{\circ} 21^{\prime} 59^{\prime \prime} \mathrm{W}, 617 \mathrm{~m}$ alt., transition zone, open and dry forest of mainly Psidium galapageium, with some Scalesia pedunculata and Pisonia floribunda, and basalt outcrops, on bark, 21-Oct-2007, Bungartz, F. 7121 (CDS 37606); dirt road to Mina Granillo Rojo, on the N-side of the island, $0^{\circ} 36^{\prime} 52^{\prime \prime} \mathrm{S}, 90^{\circ} 22^{\prime} 11^{\prime \prime} \mathrm{W}, 547 \mathrm{~m}$ alt., transition zone, upper transition zone with Bursera graveolens, Psidium galapageium and Zanthoxylum fagara, slope $10^{\circ} \mathrm{N}$, on bark, 20-Aug-2008, Truong, C. 1314 (CDS 39625); Herrera-Campos, M.A. 10783 (CDS 40521), 10790 (CDS 40528); 0 36'55"S, 90²2'0"W, $579 \mathrm{~m}$ alt., transition zone, upper transition zone with Bursera graveolens, Psidium galapageium and Zanthoxylum fagara, slope $10^{\circ} \mathrm{N}$, on bark, 20-Aug-2008, Herrera-Campos, M.A. 10818 (CDS 40556); off the dirt road to Mina Granillo Rojo, on the N-side of the island, $0^{\circ} 37^{\prime} 2^{\prime \prime} \mathrm{S}, 90^{\circ} 22^{\prime} 6^{\prime \prime} \mathrm{W}, 294 \mathrm{~m}$ alt., transition zone, deciduous forest of Zanthoxylum fagara, Psidium galapageium, Pisonia floribunda and few Bursera graveolens and Cedrela odorata, on bark, 21-Jun-2006, López, A. 656 (CDS 43981); cerca de la mina de granillo rojo, vía a Baltra, $0^{\circ} 37^{\prime} 2^{\prime \prime} \mathrm{S}, 90^{\circ} 22^{\prime} 6^{\prime \prime} \mathrm{W}, 290 \mathrm{~m}$ alt., zona de transición, con árboles de Bursera, Opuntia y Croton, Psidium galapageium 'guayabillo', Piscidia carthagenensis 'matazarno', sobre corteza, 21-Jun-2006, Nugra, F. 1 (CDS 32654); Garrapatero Bay, site 3, $0^{\circ} 41^{\prime} 27^{\prime \prime} \mathrm{S}, 90^{\circ} 13^{\prime 2} 4^{\prime \prime} \mathrm{W}$, 26-Jul-2000, LeDee, O.E. OEL-0007 (CDS 54916); El Garrapatero, about $20 \mathrm{~km} \mathrm{NE}$ of Puerto Ayora, $0^{\circ} 41^{\prime} 30^{\prime \prime} \mathrm{S}, 90^{\circ} 13^{\prime} 39^{\prime \prime} \mathrm{W}$, m alt., dry zone, on bark, 14-Feb-2005, Tehler, A. 8641 (CDS 40605); about midway on the road between Puerto Ayora and Canal de Itabaca, $0^{\circ} 37^{\prime} 24^{\prime \prime} \mathrm{S}$, $90^{\circ} 24^{\prime} 49^{\prime \prime} \mathrm{W}, 575 \mathrm{~m}$ alt., humid zone, on bark, 17-Feb-2005, Tehler, A. 8673 (CDS 40636); E-side of island, trail from parking lot to to El Garrapatero beach, $0^{\circ} 41^{\prime} 34^{\prime \prime} \mathrm{S}, 90^{\circ} 13^{\prime} 16^{\prime \prime} \mathrm{W}, 2 \mathrm{~m}$ alt., dry zone, disturbed forest of old Hippomane mancinella trees and Scutia spicata in the understory, 16-Jun-2010, Nugra, F. 868 (CDS 44937). SANTIAGO: near James Bay, $0^{\circ} 13^{\prime} 45^{\prime \prime} \mathrm{S}$, $90^{\circ} 48^{\prime} 30^{\prime \prime} \mathrm{W}, 240 \mathrm{~m}$ alt., dry zone, recent pahoehoe lava flow vegetated by Opuntia and shrubby Compositae, on bark, 01-May-1971, Pike, L.H. 2686 (OSC 51881); $2 \mathrm{~km} \mathrm{E} \mathrm{of} \mathrm{the}$ eastern peak, $0^{\circ} 13^{\prime} 0^{\prime \prime} \mathrm{S}, 90^{\circ} 45^{\prime} 0^{\prime \prime} \mathrm{W}, 725 \mathrm{~m}$ alt., humid zone, open Zanthoxylum forest in the highlands, 06-May-1971, Pike, L.H. ID26-10 (OSC 51883); $9 \mathrm{~km} \mathrm{E} \mathrm{of} \mathrm{the} \mathrm{eastern} \mathrm{summit,}$ $0^{\circ} 13^{\prime} 45^{\prime \prime} \mathrm{S}, 90^{\circ} 42^{\prime} 0^{\prime \prime} \mathrm{W}, 250 \mathrm{~m}$ alt., dry zone, Bursera forest with Croton and Clerodendron on hilltop, 10-May-1971, Pike,
L.H. ID (L-56188, COLO 263265), ID36-34 (OSC 51885); $\sim 7 \mathrm{~km}$ inland from the E-coast, \pm at the same latitude as Bahía Sullivan, $0^{\circ} 17^{\prime} 4^{\prime \prime} \mathrm{S}, 90^{\circ} 38^{\prime} 21^{\prime \prime} \mathrm{W}, 190 \mathrm{~m}$ alt., dry zone, scrubland of Castela galapageia and Macraea laricifolia with occasional trees of Bursera graveolens, Zanthoxylum fagara and Psidium galapageium, on bark, 17-Jul-2006, Bungartz, F. 5067 (CDS 29280); Nugra, F. 96 (CDS 32750); along the trail from Bucanero to Jaboncillos, $\sim 200 \mathrm{~m}$ below the summit, Cerro Gavilan, $0^{\circ} 12^{\prime} 9^{\prime \prime} \mathrm{S}, 90^{\circ} 47^{\prime} 3^{\prime \prime} \mathrm{W}, 796 \mathrm{~m}$ alt., transition zone, upper transition zone; open Psidium galapageium forest with Zanthoxylum fagara, dense understory of Clerodendrum molle, Tournefortia pubescens and others, on bark, 23-Mar-2006, Bungartz, F. 4741 (CDS 28852); along the trail from Bucanero to Jaboncillos, $\sim 2 \mathrm{~km}$ SE of Bucanero, $0^{\circ} 10^{\prime} 34^{\prime \prime} \mathrm{S}, 90^{\circ} 48^{\prime} 55^{\prime \prime} \mathrm{W}, 225 \mathrm{~m}$ alt., dry zone, open woodland with Bursera graveolens, Erythrina sp.; Vallesia glabra, Castela galapageia, Cordia lutea and grasses (e.g. Cenchrus platyacanthus) among basalt boulders and outcrops, on bark, 22-Mar-2006, Bungartz, F. 4578 (CDS 28665); Aptroot, A. 65363 (CDS 31949); Cerro Gavilan, directly below the summit at the NE-exposed slope, $0^{\circ} 12^{\prime} 19^{\prime \prime} \mathrm{S}$, $90^{\circ} 47^{\prime} 6^{\prime \prime} \mathrm{W}, 828 \mathrm{~m}$ alt., humid zone, formerly with scrub or forest, disturbed by former grazing therefore shrubs and trees missing; artificial pampa with Solanum americanum, Portulaca oleraceum, Senna occidentalis, Borreria laevis, and grasses, basalt boulders and outcrops, on bark, 23-Mar-2006, Bungartz, F. 4723 (CDS 28821), 4724 (CDS 28822); along trail to summit above Santiago Bay lava flow, $0^{\circ} 13^{\prime} 0^{\prime \prime} \mathrm{S}, 90^{\circ} 47^{\prime} 30^{\prime \prime} \mathrm{W}, 680 \mathrm{~m}$ alt., humid zone, dense stand of Zanthoxylum, Croton, and Psychotria, 03-May-1971, Pike, L.H. ID (L-56187, COLO 263264), ID21-4 (OSC 51884). PINTA: along the trail up to the summit from the S-coast, $0^{\circ} 33^{\prime} 57^{\prime \prime} \mathrm{N}, 90^{\circ} 44^{\prime} 51^{\prime \prime} \mathrm{W}, 215 \mathrm{~m}$ alt., transition zone, dense vegetation of Bursera graveolens, Croton scouleri, Scalesia baurii, Pisonia floribunda, and Zanthoxylum fagara, on bark, 25-Feb-2007, Bungartz, F. 5694 (CDS 33331); SW-part of the island, along trail going up the southwestern slope to Las Pampas on the western saddle, $0^{\circ} 34^{\prime} 13^{\prime \prime} \mathrm{N}, 90^{\circ} 45^{\prime} 38^{\prime \prime} \mathrm{W}, 316 \mathrm{~m}$ alt., transition zone, open forest of Trema micrantha, Bursera graveolens, Pisonia floribunda, Opuntia galapageia, Zanthoxylum fagara and Chiococca alba on flat lava flow, on bark, 30-Jan-2008, Nugra, F. 569 (CDS 38947). PINZÓN: 14-Dec1982, Luong, T.T. s.n. (CDS 10895); lower N-slope, 300 m alt., transition zone, on bark, Cavagnaro, D. s.n. (L-40498, COLO 192823); on bark, 07-Feb-1964, Cavagnaro, D. s.n. (L-40147, COLO 189442), s.n. (L-40148, COLO 189443); Snodgrass, R.E. s.n. (CAS-DS 681270); summit area, transition zone, on bark, 15-Feb-1964, Weber, W.A. s.n. (L-40520, COLO 192834); nesting area for tortoises, $0^{\circ} 36^{\prime} 46^{\prime \prime} \mathrm{S}, 90^{\circ} 40^{\prime} 13^{\prime \prime} \mathrm{W}, 303 \mathrm{~m}$ alt., transition zone, lower transition zone, on bark, 25-Nov-2005, Guézou, A. 209 A (CDS 39128), 204 A (CDS 39129); along the trail going up from Playa Escondida, N- to W-facing cliff above a crater, $0^{\circ} 36^{\prime} 29^{\prime \prime} \mathrm{S}, 90^{\circ} 40^{\prime} 14^{\prime \prime} \mathrm{W}, 318 \mathrm{~m}$ alt., transition zone, dry transition zone with Cordia lutea, Croton scouleri, and at the bottom of the cliff also Scalesia baurii ssp. baurii, on bark, 16-Feb-2006, Bungartz, F. 3584 (CDS 27393). RÁBIDA: 02-Feb-1964, Dawson, E.Y. s.n. (L-40119, COLO 188167); E-side of the island, dry zone, Bursera forest and lava talus slope, 01-May-1976, Weber, W.A. s.n. (L-62867, COLO 294654). FLOREANA: Oertiz-C., F. s.n. (L-40794, COLO 192309); Koford, C.B. s.n. (L-40780, COLO 193445); Itow, S. s.n. (L-40772, COLO 193441); $560 \mathrm{~m}$ alt., humid zone, on bark, Itow, S. s.n. (L-40712, COLO 192201); inland trail, on bark, 28-Jan-1934, Taylor, W.R. 865 (FH 197409); trail from Black Beach to highlands, 25-Apr-1976, Weber, W.A. s.n. (L-62963, COLO 294559); Cerro Alieri, $1^{\circ} 17^{\prime} 18^{\prime \prime} \mathrm{S}, 90^{\circ} 26^{\prime} 60^{\prime \prime} \mathrm{W}, 370 \mathrm{~m}$ alt., zona húmeda, sobre corteza, 23-Mar-2006, Simbaña, W. 550 (CDS 32386); caldera of Cerro Pajas, trail at the end of 

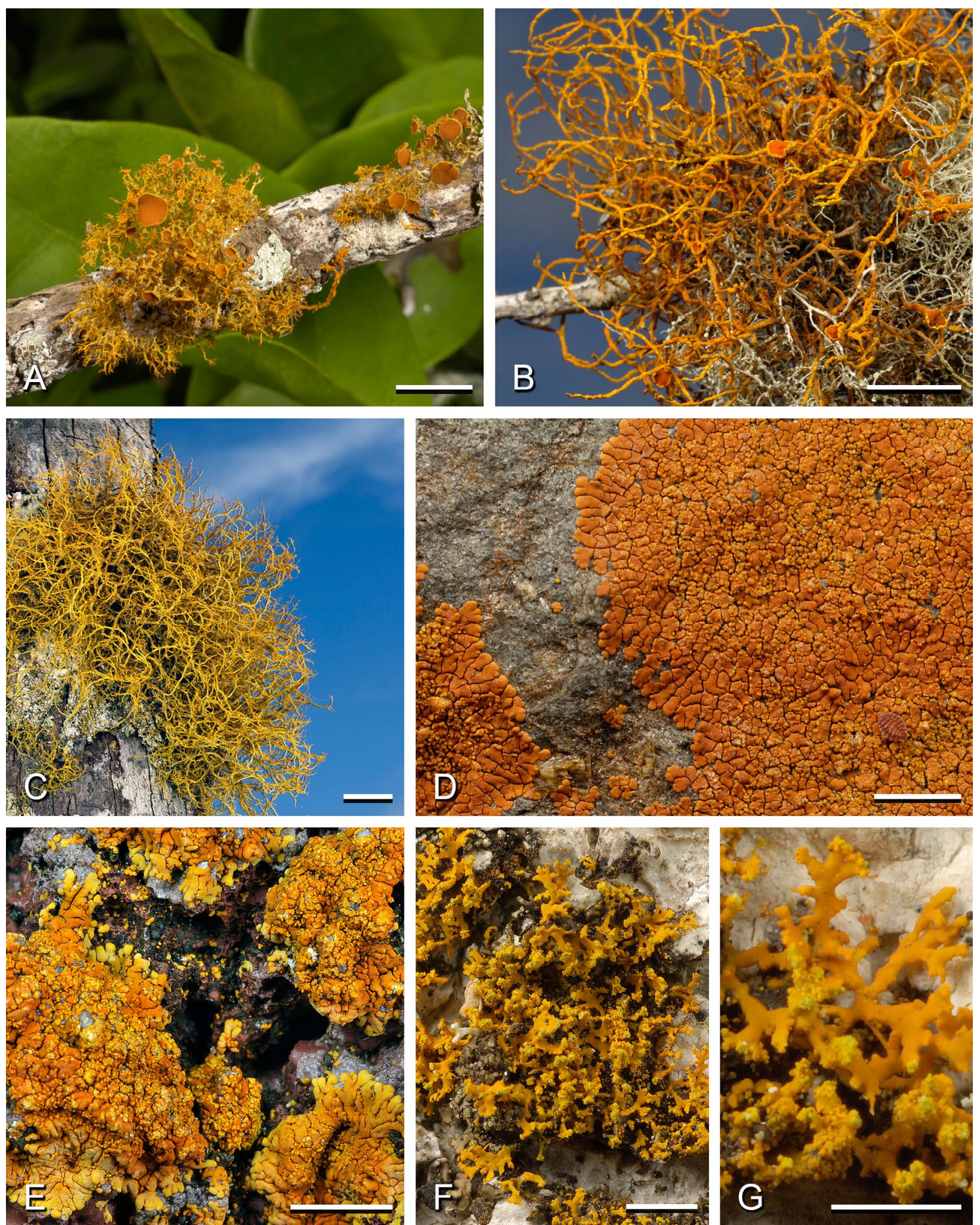

Figure 18. Species of Teloschistes, Wetmoreana \& Xanthomendoza in the Galapagos. A - Thallus of Teloschistes chrysophthalmus, abundantly fertile, lacking soredia (Bungartz, F. 4422, CDS 28507). B-C - Teloschistes flavicans. B - Sorediate thallus with few apothecia (Bungartz, F. 8541, CDS 41187); C - Sorediate thallus lacking apothecia (Bungartz, F. 4723, CDS 28821). D-E - Wetmoreana brouardii. D - Thallus deep orange, epruinose, papillae mostly intact (Bungartz, F. 4722, CDS 28820); E - Thallus deep orange and weakly pruinose in the center, with deep yellow, strongly pruinose lobes, papillae mostly breaking apart into deep yellow soredia (Bungartz, F. 3580, CDS 27389). F-G - Xanthomendoza leoncita (Bungartz, F. 4417, CDS 28502-holotype); F - Thallus yellow, epruinose, minutely foliose. G - Close-up of orange thallus lobes with deep yellow terminal blastidia. Scales: $A-C=10 \mathrm{~mm} ; \mathrm{D}-\mathrm{F}=2 \mathrm{~mm} ; \mathrm{G}=1 \mathrm{~mm}$. 
road leading up to crater rim, $1^{\circ} 17^{\prime} 54^{\prime \prime} \mathrm{S}, 90^{\circ} 27^{\prime} 22^{\prime \prime} \mathrm{W}$, humid zone, forest, on bark, 02-Jan-2010, Hillmann, G. GAL-62 (CDS 44842); Cerro Pajas, inside the crater, around the small hut, at the end of trail off the dirt road to the highlands, $1^{\circ} 17^{\prime} 50^{\prime \prime} \mathrm{S}$, $90^{\circ} 27^{\prime} 23^{\prime \prime} \mathrm{W}, 376 \mathrm{~m}$ alt., humid zone, edge of Scalesia pedunculata forest with Croton scouleri and ferns in the understory, on bark, 12-Jan-2011, Bungartz, F. 9383 (CDS 46670); Asilo de la Paz, Cerro Wittmer, trail in between cliffs, $1^{\circ} 18^{\prime} 50^{\prime \prime} \mathrm{S}$, $90^{\circ} 27^{\prime} 13^{\prime \prime} \mathrm{W}$, humid zone, on bark, 03-Jan-2010, Hillmann, G. GAL-118 (CDS 44877); on W-slope of Cerro Alieri, $1^{\circ} 17^{\prime} 24^{\prime \prime} \mathrm{S}$, $90^{\circ} 27^{\prime} 8^{\prime \prime} \mathrm{W}, 347 \mathrm{~m}$ alt., transition zone, dense forest of Croton scouleri with few Scalesia pedunculata, Citrus sp. and Zanthoxylum fagara, on bark, 12-Jan-2011, Bungartz, F. 9313 (CDS 46539); Pampa Larga, S of Cerro Asilo de la Paz, $1^{\circ} 19^{\prime} 38^{\prime \prime}$ S, $90^{\circ} 27^{\prime} 11^{\prime \prime} \mathrm{W}, 249 \mathrm{~m}$ alt., transition zone, herbaceous vegetation with dominant Phyla strigulosa, occasional grasses and other herbs, few small shrubs of Geoffroea spinosa, on bark, 13-Jan2011, Bungartz, F. 9439 (CDS 46726), 9444 (CDS 46731); plain between the two hills Cerro de los Chanchos and Cerro de los Burros, $1^{\circ} 16^{\prime} 40^{\prime \prime} \mathrm{S}, 90^{\circ} 24^{\prime} 12^{\prime \prime} \mathrm{W}, 311 \mathrm{~m}$ alt., transition zone, open herbaceous area surrounded by dense forest of Clerodendrum molle and Croton scouleri, some rocks and boulders on the ground, on bark, 21-Jan-2011, Bungartz, F. 10010 (CDS 47379 ); at the base of Cerro Comunista, $1^{\circ} 17^{\prime} 22^{\prime \prime} \mathrm{S}, 90^{\circ} 28^{\prime} 22^{\prime \prime} \mathrm{W}$, $158 \mathrm{~m}$ alt., dry zone, dense low forest of Croton scouleri, Waltheria ovata and Castela galapageia with occasional trees of Acacia rorudiana and Bursera graveolens, on bark, 16-Jan-2011, Bungartz, F. 9744 A (CDS 47061), 9725 B (CDS 49525); Yánez-Ayabaca, A. 1969 (CDS 48319); lower S-slope of Cerro Ventanas, $1^{\circ} 16^{\prime} 36^{\prime \prime} \mathrm{S}, 90^{\circ} 25^{\prime} 41^{\prime \prime} \mathrm{W}, 295 \mathrm{~m}$ alt., transition zone, open shrubland of Macraea laricifolia and some lower Waltheria ovata shrubs in between, on bark, 18-Jan-2011, Bungartz, F. 9851 (CDS 47189), 9843 (CDS 47181). GARDNER (FLOREANA): flat plain in the northern part of he island, $1^{\circ} 19^{\prime} 48^{\prime \prime} \mathrm{S}, 90^{\circ} 17^{\prime} 39^{\prime \prime} \mathrm{W}, 76 \mathrm{~m}$ alt., dry zone, dry and dense scrub of Croton scouleri and Opuntia megasperma with some Scalesia villosa and occasional shrubs of Cordia lutea and Grabowskia boerhaaviaefolia, on cactus, 23-Jan-2011, Bungartz, F. 10094 (CDS 47489). SANTA FÉ: Orr, R.T. s.n. (L-40417, COLO 190143); peak, $180 \mathrm{~m}$ alt., dry zone, Koford, C.B. s.n. (L-40753, COLO 188669); on top of lava flow at the N-coast of the island, $0^{\circ} 48^{\prime} 12^{\prime \prime} \mathrm{S}, 90^{\circ} 2^{\prime} 34^{\prime \prime} \mathrm{W}, 13 \mathrm{~m}$ alt., coastal zone, open scrubland of partly dead shrubs (Croton scouleri, Cordia lutea), few shrubby Bursera graveolens, and Opuntia echios var. barringtonensis among lava rocks, on bark, 25-Oct-2007, Bungartz, F. 7158 (CDS 37642). ESPAÑOLA: Itow, S. s.n. (L-40765, COLO 190183); Bahía Manzanillo on the N-coast of the island to the highest point, $1^{\circ} 22^{\prime} 18^{\prime \prime} \mathrm{S}, 89^{\circ} 42^{\prime} 7^{\prime \prime} \mathrm{W}, 125 \mathrm{~m}$ alt., dry zone, Cordia lutea shrubland with some Prosopis juliflora shrubs at bottom of basalt outcrop, on bark, 11-Nov-2010, Bungartz, F. 9138 (CDS 45956); trail from Bahía Manzanillo on the N-coast of the island to the highest point, $1^{\circ} 21^{\prime} 40^{\prime \prime} \mathrm{S}$, $89^{\circ} 41^{\prime} 56^{\prime \prime} \mathrm{W}, 48 \mathrm{~m}$ alt., dry zone, open scrub of Cordia lutea and Prosopis juliflora with grasses and few trees of Bursera graveolens over weathered lava boulders, on bark, 11-Nov-2010, Bungartz, F. 9048 (CDS 45866); Yánez-Ayabaca, A. 1662 (CDS 45545); along S-coast of the island, SE of Punta Suárez, $60 \mathrm{~m}$ inland from coast, $1^{\circ} 22^{\prime} 58^{\prime \prime} \mathrm{S}, 89^{\circ} 43^{\prime} 15^{\prime \prime} \mathrm{W}, 113 \mathrm{~m}$ alt., dry zone, Cordia lutea shrubland with Prosopis juliflora, on bark, 10-Nov2010, Bungartz, F. 8928 (CDS 45746). WOLF: summit plateau, dry zone, on bark, 15-Feb-1964, Weber, W.A. 212 (L-40370, FH 197412); Cavagnaro, D. s.n. (L-40370, COLO 188581).

Wetmoreana Arup, Søchting \& Frödén, in Arup, Søchting \& Frödén, Nordic J1 Bot. 31(1): 66. 2013.

MycoBank MB 802011
Wetmoreana brouardii (B. de Lesd.) Wilk \& Søchting, comb. nov.

(Figs 2, 18D-E)

\section{MycoBank MB 836904}

Basionym: Placodium brouardii B. de Lesd., Lich. Mexique 11. 1914; MycoBank MB 401030.

Description. Thallus placodioid, of \pm isodiametric, angular, convex areoles in the center and shortly elongated, moderately convex to broadly flattened, $\sim 0.3 \mathrm{~mm}$ broad lobes along the periphery, individual thalli up to $3 \mathrm{~cm}$ in diam., but several thalli frequently confluent, merging with one another; hypothallus and prothallus absent; surface smooth to dull, not shiny, orange to deep orange, epruinose or, especially on the marginal lobes, with pale orange, farinose pruina; central areoles strongly papillate; papillae granular-globose, $\sim 0.2 \mathrm{~mm}$ in diam., apically often breaking apart to extrude coarse, blastidiate soredia, (27-)28-41(-42) $\mu \mathrm{m}$ in diam. Apothecia not seen. Pycnidia not observed.

Chemistry. Thallus $\mathrm{P}-, \mathrm{K}+$ purple, $\mathrm{C}-, \mathrm{KC} \pm$ purplish (fading), UV-(dull); with dominant parietin and smaller proportions of fallacinal together with traces of teloschistin, parietinic acid and emodin. In some specimens the thallus contains significant proportions of the depsidones isofulgidin and vicanicin. This corresponds to chemosyndrome A3+2 sensu Søchting \& Frödén (2002) and is the same as found in specimens from Baja California.

Ecology and distribution. Africa, North and South America (Brazil, Guatemala, Peru; see Wetmore \& Kärnefelt 1998). It is new to Ecuador and the Galapagos, where the species is only moderately common, growing on rock in sheltered to \pm exposed habitats throughout the transition zone, less frequently also in the humid zone.

Notes. The specimens from Galapagos are morphologically indistinguishable from specimens from the Sonoran Desert, but the few analyzed specimens may suggest the Galapagos material to represent a separate genotype. More material from the American continents is needed to elucidate this.

Specimens examined from Ecuador, Galápagos. VOLCÁN ALCEDO, ISABELA: outer SE-exposed slope and crater rim, $0^{\circ} 27^{\prime} 29^{\prime \prime} \mathrm{S}, 91^{\circ} 7^{\prime} 19^{\prime \prime} \mathrm{W}, 1089 \mathrm{~m}$ alt., humid zone, tortoise pasture with scattered trees (Tournefortia rufo-sericea, Zanthoxylum fagara), on rock, 05-Mar-2006, Aptroot, A. 65107 (CDS 31689); Bungartz, F. 4053 (CDS 27983). SANTIAGO: Cerro Gavilan, directly below the summit at the NE-exposed slope, $0^{\circ} 12^{\prime} 19^{\prime \prime} \mathrm{S}$, $90^{\circ} 47^{\prime} 6^{\prime \prime} \mathrm{W}, 828 \mathrm{~m}$ alt., humid zone, formerly with scrub or forest, disturbed by former grazing therefore shrubs and trees missing; artificial pampa with Solanum americanum, Portulaca oleraceum, Senna occidentalis, Borreria laevis, and grasses, basalt boulders and outcrops, on rock, 23-Mar-2006, Bungartz, F. 4722 (CDS 28820). SAN CRISTÓBAL: Cerro Partido along trail from entrance to Cerro Pelado to El Ripioso, $0^{\circ} 51^{\prime} 23^{\prime \prime} \mathrm{S}$, $89^{\circ} 27^{\prime} 37^{\prime \prime} \mathrm{W}, 376 \mathrm{~m}$ alt., transition zone, rocky SW-exposed slope of hill with Jasminocereus thouarsii, Clerodendrum molle var. glabrescens, Psidium galapageium, Bromeliaceae and ferns growing in rock crevices, on rock, 28-Apr-2007, Bungartz, F. 6638 (CDS 34858); Cerro Mundo, at the base of the rock cliffs on the $\mathrm{S}$ side close to the summit, $0^{\circ} 53^{\prime} 32^{\prime \prime} \mathrm{S}, 89^{\circ} 34^{\prime} 40^{\prime \prime} \mathrm{W}, 243 \mathrm{~m}$ 
alt., transition zone, with Bursera graveolens, Croton scouleri, Piscidia carthagenensis, Zanthoxylum fagara and a few Scalesia pedunculata, slope $45^{\circ}$ ESE, on rock, 25-Aug-2008, Clerc, P. 08-389 (CDS 40243); walking up the encañada of the S-slope of Cerro Mundo, NE of Puerto Baquerizo Moreno, $0^{\circ} 53^{\prime} 32^{\prime \prime} \mathrm{S}$, $89^{\circ} 34^{\prime} 37^{\prime \prime} \mathrm{W}, 162 \mathrm{~m}$ alt., transition zone, rocky, dry bed of periodical stream in native forest of Hippomane mancinella, Psidium galapageium, Zanthoxylum fagara and Bursera graveolens, on rock, 25-Aug-2008, Bungartz, F. 8681 (CDS 41327); trail to Cerro Mundo, passing by the 'cañadas', $0^{\circ} 53^{\prime} 33^{\prime \prime} \mathrm{S}, 89^{\circ} 34^{\prime} 40^{\prime \prime} \mathrm{W}$, $200 \mathrm{~m}$ alt., transition zone, with Hippomane mancinella, Zanthoxylum fagara, Psidium galapageium, P. guajava and Kalanchoe pinnata and Mormordica charantia invading the understory, slope $10^{\circ}-25^{\circ} \mathrm{WNW}$, on rock, 25-Aug-2008, Herrera-Campos, M.A. GAL-488 (CDS 43379). SANTA CRUZ: off the dirt road to Mina Granillo Rojo, on the N-side of the island, $0^{\circ} 37^{\prime} 2^{\prime \prime} \mathrm{S}, 90^{\circ} 22^{\prime} 6^{\prime \prime} \mathrm{W}, 294 \mathrm{~m}$ alt., transition zone, deciduous forest of Zanthoxylum fagara, Psidium galapageium, Pisonia floribunda and few Bursera graveolens and Cedrela odorata, on rock, 21-Jun-2006, Yánez-Ayabaca, A. 301 (CDS 43988); along the road from Los Gemelos towards the N-coast of the island, $\sim 1.2 \mathrm{~km} \mathrm{~N}$ of Los Gemelos, $0^{\circ} 37^{\prime} 18^{\prime \prime} \mathrm{S}, 90^{\circ} 22^{\prime} 43^{\prime \prime} \mathrm{W}, 573 \mathrm{~m}$ alt., transition zone, upper transition zone; open dry decidous forest with Bursera graveolens, and Zanthoxylum fagara, on rock, 12-Feb-2006, Aptroot, A. 63761 (CDS 30321). PINZÓN: along the trail going up from Playa Escondida, $\mathrm{N}$ - to $\mathrm{W}$-facing cliff above a crater, $0^{\circ} 36^{\prime} 29^{\prime \prime} \mathrm{S}, 90^{\circ} 40^{\prime} 14^{\prime \prime} \mathrm{W}, 318 \mathrm{~m}$ alt., transition zone, dry transition zone with Cordia lutea, Croton scouleri, and at the bottom of the cliff also Scalesia baurii ssp. baurii, on rock, 16-Feb-2006, Bungartz, F. 3580 (CDS 27389); Aptroot, A. 64015 (CDS 30576).

Xanthorioideae Arup, Søchting \& Frödén, subfam. nov.

\section{MycoBank MB 837366}

Type genus: Xanthoria Th. Fr.

Taxonomic note: The name for this subfamily was originally proposed by Gaya et al. (2012) and adopted by Arup et al. (2013a). Both published the subfamily without a diagnosis, which is here provided to formally validate the name.

Diagnosis: The subfamily represents a major, well-supported clade in the molecular phylogeny of Teloschistaceae. It differs from Caloplacoideae in the following nrLSU sequences DNA pattern: usually having a $\mathrm{G}$ (rarely A or C) versus an A (rarely G, C or lacking) in the sequence AGGTG(alt. A)GGAACCCNGGGGCGCACC(alt. T)ATCGA; and in the following mrSSU DNA sequence pattern: usually having a $G(A)$ versus usually an $\mathrm{A}(\mathrm{T})$ in the sequence TATGCCTTACAAAGGGATGCTAAATT, and from the Teloschistoideae in the mrSSU sequence pattern usually having a A (T) versus usually an $\mathrm{T}$ in the sequence TTCTGGGTAGGCTTTTGATAATGACA and in usually having an A or a $T(G)$ versus a $G$ in the sequence AGATTAGATA(alt. T)TAATTTGATCTA. The subfamily Xanthorioideae includes mainly species from the Northern Hemisphere. With very few exceptions the secondary chemistry consists of chemosyndrome A or A3 with parietin as the dominant anthraquinone. The majority of species in this subfamily are crustose, with a few genera being mainly foliose or including fruticose species.
Squamulea Arup, Søchting \& Frödén, in Arup, Søchting \& Frödén, Nordic Jl Bot. 31(1): 55. 2013.

\section{MycoBank MB 802003}

New synonym: Huriella S.Y. Kondr., in Kondratyuk, Lőkös, Upreti, Nayaka, Mishra, Ravera, Jeong, Jang, Park \& Hur, Acta bot. hung. 59(1-2): 101. 2017; MycoBank MB 819645.

Taxonomic note: Classical morpho-anatomical characters in the genus Squamulea are extremely variable and presently insufficiently understood to be useful for reliable differentiation of the species treated here. We therefore decided to only provide brief diagnoses, even for the newly described species. Phylogenetically, these newly described species are all clearly distinct, reliably identified by their ITS barcoding sequence. Morphological and anatomical characters remain cryptic; the diagnoses provided here emphasize characteristics that may be useful to preliminarily identify Galapagos specimens. The species are, however, generally much more variable than these brief descriptions imply.

Squamulea chelonia Bungartz \& Søchting, sp. nov.

(Figs 3, 13C-E)

\section{MycoBank MB 836954}

Diagnosis: A saxicolous species with thalli composed of dull, yellow-orange to deep orange, angular areolate to indistinctly subsquamulose, loosely dispersed to closely aggregated areoles, their surface epruinose or farinose whitish pruinose (particularly if growing on calcareous substrates), without a distinct prothallus, apothecia immersed to adnate, disc epruinose, deeper in color than the thallus; $(6.6-) 8.0-10.4(-11.8) \times$ $(4.2-) 4.7-6.0(-6.8) \mu \mathrm{m}$, with a moderately thickened, (1.4-)2.1$3.3(-3.7) \mu \mathrm{m}$ wide septum $(\mathrm{n}=27)$. The new species is reliably distinguished from other morphologically extremely similar species in Squamulea by its different ITS sequence.

Type: Ecuador, Galápagos: San Cristóbal, hills S of Punta Pit at the NE-coast of the island, $0^{\circ} 43^{\prime} 8^{\prime \prime} \mathrm{S}, 89^{\circ} 14^{\prime} 36^{\prime \prime} \mathrm{W}, 44 \mathrm{~m}$ alt., dry zone, NE-exposed cliff of basalt lava with some Cordia lutea shrubs and abundant Mentzelia aspera as ground cover, on rock, 21-Apr-2007, Bungartz, F. 6146 (CDS 34358-holotype; GenBank Accession number nrITS: MT967452).

Chemistry. Thallus and apothecia $\mathrm{P}-, \mathrm{K}+$ purple, $\mathrm{C}-$, $\mathrm{KC} \pm$ purplish, $\mathrm{UV}-($ dull); thallus and apothecia with a large proportion of parietin and smaller proportions of teloschistin, fallacinal, parietinic acid and emodin (chemosyndrome A sensu Søchting 1997).

Ecology and distribution. Currently, known only from the Galapagos and possibly endemic; most specimens were collected in the humid zone, some in the transition zone, and even a few in the dry zone; on exposed rocks and boulders, occasionally in crevices; frequently at dust-impregnated, nitrophytic, slightly calcareous sites, there growing with other, similar species of Squamulea (e.g., S. humboldtiana, S. phyllidizans).

Etymology. The epithet chelonia recalls Greek mythology, 'khelônê' meaning tortoise. Chelone was a nymph changed by the Greek gods into a tortoise. The archipelago is of course named for its most iconic species, the Galapagos Giant Tortoise (the genus Chelonoidis is endemic to the archipelago). Here, we select this epithet for one of the lichens that might be endemic as well. 
Notes. Squamulea chelonia is morphologically virtually indistinct from specimens of $S$. subsoluta s.l. and specimens are extremely similar to $S$. oceanica too. All have minute, thin and poorly developed areoles that are typically not squamulose, if at all with angular, barely subsquamulose edges. On calcareous substrates, thalli of S. chelonia are often pruinose. Galapagos specimens appear to have more closely aggregated areoles than the scattered ones of $S$. oceanica, which typically develop from a thin, \pm shiny hypothallus. None of this morphological variation is well-defined and the species must be considered cryptic.

Specimens examined from Ecuador, Galápagos. ISABELA, VOLCÁN DARWIN: $\sim 1.5 \mathrm{~km}$ from the southwestern crater rim, $0^{\circ} 12^{\prime} 20^{\prime \prime} \mathrm{S}, 91^{\circ} 18^{\prime} 52^{\prime \prime} \mathrm{W}, 1280 \mathrm{~m}$ alt., high-altitude dry zone, basalt outcrop bare of vegetation, on rock, 14-Nov-2007, Ertz, D. 11880 (CDS 37239); southwestern slope, above Tagus Cove, $0^{\circ} 13^{\prime} 25^{\prime \prime} \mathrm{S}, 91^{\circ} 19^{\prime} 13^{\prime \prime} \mathrm{W}, 900 \mathrm{~m}$ alt., transition zone, top of lava flow of weathered AA-lava with scarce vegetation (Jasminocereus thouarsii, Dodonaea viscosa, Chiococca alba, Macraea laricifolia), on rock, 15-Nov-2007, Bungartz, F. 7776 (CDS 38284). VOLCÁN SIERRA NEGRA: along dirt road from Puerto Villamil to crater of Sierra Negra, $0^{\circ} 55^{\prime} 12^{\prime \prime} \mathrm{S}, 90^{\circ} 59^{\prime} 38^{\prime \prime} \mathrm{W}, 30 \mathrm{~m}$ alt., dry zone, old lava flow with scattered vegetation (Bursera graveolens, Opuntia echios, and Waltheria ovata), on rock, 10-Sep-2007, Bungartz, F. 6950 (CDS 36454); Muro de las Lagrimas, $\sim 5 \mathrm{~km} \mathrm{~W}$ of Puerto Villamil, $0^{\circ} 57^{\prime} 52^{\prime \prime} \mathrm{S}, 91^{\circ} 0^{\prime} 46^{\prime \prime} \mathrm{W}$, $78 \mathrm{~m}$ alt., dry zone, wall of basalt boulders, SE-exposed, on rock, 17-Aug-2008, Bungartz, F. 8433 (CDS 41079); Muro de las Lagrimas W of Puerto Villamil, along the stairs going up behind the wall, $0^{\circ} 57^{\prime} 52^{\prime \prime} \mathrm{S}, 91^{\circ} 0^{\prime} 46^{\prime \prime} \mathrm{W}, 78 \mathrm{~m}$ alt., dry zone, dry zone vegetation with Bursera graveolens and Opuntia echios, slope $45^{\circ} \mathrm{N}$, on rock, 17-Aug-2008, Truong, C. 1248 (CDS 39559). SANTIAGO: $\sim 5 \mathrm{~km}$ inland from the E-coast, \pm at the same latitude as Bahía Sullivan, $0^{\circ} 16^{\prime} 52^{\prime \prime} \mathrm{S}, 90^{\circ} 37^{\prime} 17^{\prime \prime} \mathrm{W}, 175 \mathrm{~m}$ alt., dry zone, rubble of older lava with very scarce vegetation of few Bursera graveolens trees, Macraea laricifolia, and Mentzelia aspera, on rock, 16-Jul-2006, Bungartz, F. 5047 (CDS 29260), 5050 (CDS 29263); NW-side of cinder cone $1 \mathrm{~km}$ SE of Santiago Bay, $0^{\circ} 15^{\prime} 0^{\prime \prime} \mathrm{S}, 90^{\circ} 51^{\prime} 15^{\prime \prime} \mathrm{W}, 30 \mathrm{~m}$ alt., dry zone, along sides of trench containing the spring, on consolidated ash, 24-Apr-1971, Pike, L.H. 2619 (L-55215, COLO 255643). PINTA: along the trail up to the summit from the S-coast, $0^{\circ} 33^{\prime} 46^{\prime \prime} \mathrm{N}, 90^{\circ} 44^{\prime} 46^{\prime \prime} \mathrm{W}$, $174 \mathrm{~m}$ alt., transition zone, old SW-exposed lava flow in open woodland with Bursera graveolens, Croton scouleri, Opuntia galapageia, few Pisonia floribunda, and with Scalesia baurii in the understory, on rock, 28-Feb-2007, Bungartz, F. 5993 (CDS 33671). RÁBIDA: on rock, 15-Feb-1964, Dawson, E.Y. 377 (L-41042, COLO 192037). SANTA FÉ: Yankee Bay, on rock, 09-Jun-1971, Weber, W.A. s.n. (L-54812, COLO 255240). PINZÓN: in the valley on the W-slope of the highest mountain, $0^{\circ} 36^{\prime} 41^{\prime \prime} \mathrm{S}, 90^{\circ} 40^{\prime} 11^{\prime \prime} \mathrm{W}, 310 \mathrm{~m}$ alt., dry zone, dry zone vegetation with Prosopis juliflora, Alternanthera filifolia, Maytenus octogona, and Croton scouleri, on rock, 16-Feb-2006, Aptroot, A. 64100 (CDS 30661). SANTA CRUZ: Puerto Ayora, $150 \mathrm{~m}$ from Research Station, coastal zone, on rock, 10-Apr-1976, Weber, W.A. s.n. (CDS 10815), s.n. (QCA); along the S-coast of Santa Cruz close to the Charles Darwin Research Station (CDRS), Puerto Ayora, $0^{\circ} 44^{\prime} 35^{\prime \prime} \mathrm{S}, 90^{\circ} 18^{\prime} 14^{\prime \prime} \mathrm{W}, 1 \mathrm{~m}$ alt., coastal zone, bare lava rocks, Cryptocarpus pyriformis occasionally in between, on rock, 10-Feb-2006, Bungartz, F. 3412 (CDS 27118), 3410 (CDS 27116); along the road from Los Gemelos towards the N-coast of the island, $\sim 1 \mathrm{~km} \mathrm{~N}$ of Los Gemelos, $0^{\circ} 37^{\prime} 22^{\prime \prime} \mathrm{S}$, $90^{\circ} 22^{\prime} 47^{\prime \prime} \mathrm{W}, 584 \mathrm{~m}$ alt., transition zone, upper transition zone with open dry forest, Scalesia pedunculata, Chiococca alba,
Tournefortia rufo-sericea, Cordia leucophlyctis, and Zanthoxylum fagara, on rock, 12-Feb-2006, Bungartz, F. 3526 (CDS 27304); Puerto Ayora, near Charles Darwin Research Station (CDRS), $0^{\circ} 44^{\prime} 32^{\prime \prime} \mathrm{S}, 90^{\circ} 18^{\prime} 10^{\prime \prime} \mathrm{W}, 5 \mathrm{~m}$ alt., coastal zone, on rock, 24-May-2005, Aptroot, A. 63122 (CDS 29852); cliff N of the town, $0^{\circ} 43^{\prime} 59^{\prime \prime} \mathrm{S}, 90^{\circ} 18^{\prime} 45^{\prime \prime} \mathrm{W}, 20 \mathrm{~m}$ alt., dry zone, on rock, 11-Feb-2006, Aptroot, A. 63723 (CDS 30279).

Specimens examined (pruinose material) from Ecuador, Galápagos. SANTA CRUZ: Puerto Ayora, Charles Darwin Research Station (CDRS), 'Biomar' building site, $0^{\circ} 44^{\prime} 32^{\prime \prime} \mathrm{S}$, $90^{\circ} 18^{\prime} 10^{\prime \prime} \mathrm{W}, 1 \mathrm{~m}$ alt., coastal zone, on eternit (fiber cement), 15-Feb-2006, Aptroot, A. 63996 (CDS 30557). Bungartz, F. 9251 (CDS 46069); living quarters at the Charles Darwin Research Station, small station house behind the Thomas Fischer Science Buildings, $0^{\circ} 44^{\prime} 31.420^{\prime \prime} \mathrm{S}, 90^{\circ} 18^{\prime} 11^{\prime \prime} \mathrm{W}$, m alt., coastal zone, scrub vegetation with Cryptocarpus pyriformis, Maytenus octogona, and Scutia spicata var. pauciflora, on rock, 23-Feb-2006, Bungartz, F. 4521 (CDS 28607). FLOREANA: at the base of Cerro Comunista, $1^{\circ} 17^{\prime} 22^{\prime \prime} \mathrm{S}, 90^{\circ} 28^{\prime} 22^{\prime \prime} \mathrm{W}, 158 \mathrm{~m}$ alt., dry zone, dense low forest of Croton scouleri, Waltheria ovata and Castela galapageia with occasional trees of Acacia rorudiana and Bursera graveolens, on fiber cement, 16-Jan-2011, Bungartz, F. 9745 (CDS 47062).

Squamulea flakusii (Wilk) Arup, Søchting \& Bungartz, comb. nov.

(Figs 3, 13A-B)

\section{MycoBank MB 836955}

Basionym: Huriella flakusii Wilk, The Lichenologist 52: 39. 2020; MycoBank MB 831528.

For a detailed description of the original material from Peru refer to the protologue published in Wilk (2020).

Ecology and distribution. The species was originally described from material collected '... on siliceous rock in arid montane habitats, at elevations of c. $3500 \mathrm{~m}$ in the Colca Canyon region in southern Peru. ...' (Wilk 2020, p. 39). Wilk (2020) cites two additional specimens, also from semi-desert areas in the mountains of Peru. In Galapagos, the three specimens identified as this species using molecular tools occur also at high altitude. All three were collected near the crater rim of Volcán Alcedo, a habitat that occasionally emerges from the cloud forests below, at the upper end of the Galapagos humid zone.

Notes. Morphologically, Galapagos specimens do not closely resemble the illustration of S. flakusii published in Wilk (2020) of the holotype material described from Peru. The thallus color is not as reddish; instead Galapagos specimens are a deep yellow-orange. The concentration of anthraquinones in Teloschistaceae is generally known to vary considerably, the amount correlated to habitat exposure, cortical pigments offering protection against excess UV-light. Apothecia of the Galapagos specimens are not as conspicuously deformed as the specimen illustrated in Wilk (2020). This holotype from Peru has a poorly developed, inconspicuous thallus, which is almost absent. Wilk (2020) emphasizes, however, that the morphology of the Peruvian specimens can be very variable, from distinctly '... squamulose to strongly reduced and almost invisible'. The Galapagos specimens have distinct, relatively well-developed thalli, composed of minute subsquamulose to lobulate rosettes (Fig. 13B). Their anatomy does 
not markedly differ from the Peruvian specimens. Wilk (2020) did not examine the chemistry of S. flakusii with HPLC, but mentions that apothecia and thalli react $\mathrm{K}+$ purple. We only recently noticed that the ITS sequences from the three Galapagos specimens cited below closely match those published in Wilk (2020). Previously the material had been included among Galapagos specimens of Squamulea subsoluta/squamosa. The three specimens that we analyzed for chemistry had chemosyndrome A.

Specimens examined from Ecuador, Galápagos. ISABELA, VOLCÁN ALCEDO: outer SE-exposed slope, $\sim 100 \mathrm{~m}$ below the crater rim, $0^{\circ} 25^{\prime} 36^{\prime \prime} \mathrm{S}, 91^{\circ} 5^{\prime} 12^{\prime \prime} \mathrm{W}, 1146 \mathrm{~m}$ alt., humid zone, disturbed by former grazing of goats, Pteridium arachnoideum and Stachytarpheta cayennensis, scattered low shrubs of Tournefortia rufo-sericea and outcrops of basalt tuff in between, on rock, 06-Mar-2006, Bungartz, F. 4131 (CDS 28162), 4157 (CDS 28188); on the crater rim near the hut, $0^{\circ} 26^{\prime} 33^{\prime \prime} \mathrm{S}$, $91^{\circ} 5^{\prime} 31^{\prime \prime} \mathrm{W}, 1100 \mathrm{~m}$ alt., humid zone, Pteridium arachnoideum and Stachytarpheta cayennensis, scattered low shrubs of Tournefortia rufo-sericea and outcrops of basalt tuff in between, on rock, 07-Mar-2006, Aptroot, A. 65261 (CDS 31847)

Squamulea humboldtiana Bungartz \& Søchting, sp. nov. (Figs 3, 14A-D, 15A)

\section{MycoBank MB 836956}

Diagnosis: A saxicolous species with thalli composed of dull, yellow-orange to deep orange, moderately to strongly convex or even bullate marginal areoles with downward turned edges and \pm flattened, angular, central areoles, their surface often coarsely pruinose (especially if growing on calcareous substrates) or epruinose (on siliceous rock), some specimens delimited by a black prothallus, apothecia immersed to adnate, deeper in color than the thallus, disc epruinose; ascospores (7.9-)8.1-9.9(-10.3) $\times$ (4.7-)4.8-5.9(-6.3) $\mu \mathrm{m}$, with a moderately thickened, (2.6-)2.7$3.2(-3.6) \mu \mathrm{m}$ wide septum $(\mathrm{n}=13)$. The new species is reliably distinguished from other morphologically extremely similar species in Squamulea by its different ITS sequence.

Type: Ecuador, Galápagos: Santiago, directly below the summit at the NE-exposed slope, $0^{\circ} 12^{\prime} 19^{\prime \prime} \mathrm{S}, 90^{\circ} 47^{\prime} 6^{\prime \prime} \mathrm{W}, 828 \mathrm{~m}$ alt., humid zone, formerly with scrub or forest, disturbed by former grazing therefore shrubs and trees missing, artificial pampa with Solanum americanum, Portulaca oleraceum, Senna occidentalis, Borreria laevis, and grasses, basalt boulders and outcrops, on rock, 22-Mar-2006, Bungartz, F. 4711 B (CDS 56235-holotype; GenBank Accession number nrITS: MT967440).

Chemistry. Thallus and apothecia $\mathrm{P}-, \mathrm{K}+$ purple, $\mathrm{C}-$, $\mathrm{KC} \pm$ purplish, UV- (dull); thallus and apothecia with a large proportion of parietin and smaller proportions of teloschistin, fallacinal, parietinic acid and emodin (chemosyndrome A sensu Søchting 1997).

Ecology and distribution. Although most specimens examined are from the Galapagos, at least one specimen included in our phylogenetic analyses comes from the Caribbean island of Nevis ('West Indies'; Buck 29560, $\mathrm{MIN}$ ); the species therefore most likely is generally more common throughout the Neotropics. In the Galapagos, it occurs from the dry through the transition into the humid zone. It is a saxicolous species that grows in both shaded and \pm sheltered as well as in sunny, wind- and rain-exposed habitats.
Etymology. Named as a belated recognition of Alexander von Humboldt whose 250th birthday was celebrated in 2019. Although Humboldt never visited the Galapagos, he is perhaps the most important explorer of the natural history throughout the South American continent and thus pioneered the ecology of the Neotropics, the region inhabited by $S$. humboldtiana.

Notes. Squamulea humboldtiana is one of several 'cryptic' species of Squamulea in the Galapagos. Phylogenetically, the species is well-defined forming a distinct clade together with S. chelonia and S. oceanica (Fig. 3). Morphologically, these three species are all very similar and not well distinguished from other Squamulea species in the archipelago (particularly $S$. subsoluta s.1.). Specimens of $S$. humboldtiana are frequently found in nitrophytic, often slightly calcareous habitats; like $S$. osseophila also on bone. Areoles of the two species can be similar, both convex, almost bullate, but growing side-by-side, thalli of S. osseophila are epruinose, almost 'waxy'; those of S. humboldtiana, growing on the same piece of bone, are pruinose (Fig. 15A). The thallus morphology of S. humboldtiana can nevertheless be misleading; some specimens have distinctly more angular areoles (Fig. 14B), and not all material is pruinose.

Specimens examined (pruinose material) from Ecuador, Galápagos. FLOREANA: inside the crater of Cerro Laguna at E-side of island, on W-exposed slope, $1^{\circ} 16^{\prime} 11^{\prime \prime} \mathrm{S}, 90^{\circ} 23^{\prime} 17^{\prime \prime} \mathrm{W}$, $245 \mathrm{~m}$ alt., transition zone, dense forest of Prosopis juliflora, Clerodendrum molle, very few Bursera graveolens and some Jasminocereus thouarsii in the upper part among lava outcrops and boulders; Ramalina usnea/anceps hanging in cutains from Clerodendrum twigs, on rock, 20-Jan-2011, Bungartz, F. 9985 (CDS 47354). SANTIAGO: summit of Cerro Gavilan, outer S-exposed crater rim, $0^{\circ} 12^{\prime} 23^{\prime \prime} \mathrm{S}, 90^{\circ} 46^{\prime} 57^{\prime \prime} \mathrm{W}, 840 \mathrm{~m}$ alt., humid zone, S-exposed, steep basalt cliffs of crater rim with ferns (Pityrograma calomelanos var. calomelanos, Polypodium tridens, Dryopteris palmata, Adiantum concinnum, Blechnum polypodioides) growing in crevices, on bone, 23-Mar-2006, Aptroot, A. 65488 B (CDS 32077); inner N- and NE-exposed crater rim, $0^{\circ} 12^{\prime} 20^{\prime \prime} \mathrm{S}, 90^{\circ} 47^{\prime} 3^{\prime \prime} \mathrm{W}, 840 \mathrm{~m}$ alt., humid zone, N- and NE-exposed, steep basalt cliffs of crater rim with ferns (Pityrograma calomelanos var. calomelanos, Polypodium tridens, Dryopteris palmata, Adiantum concinnum, Blechnum polypodioides) growing in crevices, on rock, 23-Mar-2006, Aptroot, A. 65729 B (CDS 56233), 65718 B (CDS 56236); directly below the summit at the NE-exposed slope, $0^{\circ} 12^{\prime} 19^{\prime \prime} \mathrm{S}, 90^{\circ} 47^{\prime} 6^{\prime \prime} \mathrm{W}, 828 \mathrm{~m}$ alt., humid zone, formerly with scrub or forest, disturbed by former grazing therefore shrubs and trees missing; artificial pampa with Solanum americanum, Portulaca oleraceum, Senna occidentalis, Borreria laevis, and grasses, basalt boulders and outcrops, on rock, 22-Mar-2006, Bungartz, F. 4709 B (CDS 56234).

Specimens examined (epruinose material) from Ecuador, Galápagos. SANTIAGO: $\sim 7 \mathrm{~km}$ inland from the E-coast, \pm at the same latitude as Bahía Sullivan, $0^{\circ} 17^{\prime} 1^{\prime \prime} \mathrm{S}, 90^{\circ} 38^{\prime} 24^{\prime \prime} \mathrm{W}$, $183 \mathrm{~m}$ alt., dry zone, SE-exposed slope of lava flow, on rock, 17-Jul-2006, Bungartz, F. 5151 (CDS 29364). PINZÓN: along the trail going up from Playa Escondida, N- to W-facing cliff above a crater, $0^{\circ} 36^{\prime} 29^{\prime \prime} \mathrm{S}, 90^{\circ} 40^{\prime} 14^{\prime \prime} \mathrm{W}, 318 \mathrm{~m}$ alt., transition zone, dry transition zone with Cordia lutea, Croton scouleri, and at the bottom of the cliff also Scalesia baurii ssp. baurii, on rock, 16-Feb-2006, Bungartz, F. 3581 (CDS 27390); Aptroot, A. 64014 (CDS 30575). 
Squamulea oceanica Bungartz \& Søchting, sp. nov.

(Figs 3, 13F-G, 14C)

\section{MycoBank MB 836957}

Diagnosis: A saxicolous species with thalli composed of dull, yellow-orange to deep orange, typically widely dispersed areoles, their surface consistently epruinose (even when growing on calcareous substrates), areoles usually developing on a faint, thin, \pm shiny, whitish to blackened hypothallus, in some specimens distinctly separating several thalli as a distinctly blackened prothallus, apothecia adnate, disc epruinose, concolorous or barely deeper in color than the surrounding areoles; ascospores $(8.0-) 8.5-9.9(-10.4) \times(4.0-) 4.6-6.8(-7.7) \mu \mathrm{m}$, with a moderately thickened, (2.0-)2.6-3.6(-3.8) $\mu$ m wide septum $(\mathrm{n}=15)$. The new species is reliably distinguished from the morphologically similar species in Squamulea by its different ITS sequence.

Type: Ecuador, Galápagos: Florean, lower S-slope of Cerro Ventanas, $1^{\circ} 16^{\prime} 36^{\prime \prime} \mathrm{S}, 90^{\circ} 25^{\prime} 41^{\prime \prime} \mathrm{W}, 295 \mathrm{~m}$ alt., transition zone, open shrubland of Macraea laricifolia and some lower Waltheria ovata shrubs in between, on rock, 18-Jan-2011, Yánez-Ayabaca, A. 2023 (CDS 48373-holotype; GenBank Accession number nrITS: MT967445).

Chemistry. Thallus and apothecia $\mathrm{P}-, \mathrm{K}+$ purple, $\mathrm{C}-$, $\mathrm{KC} \pm$ purplish, $\mathrm{UV}-$ (dull); thallus and apothecia with a large proportion of parietin and smaller proportions of teloschistin, fallacinal, parietinic acid and emodin (chemosyndrome A sensu Søchting 1997).

Ecology and distribution. Few specimens currently known, all from the Galapagos, from the dry, through the transition into the humid zone, all from basalt (non-calcareous substrates).

Etymology. The epithet oceanica is derived from the Pacific Ocean, where the type locality on Galapagos is located.

Notes. Squamulea oceanica is, like most Squamulea species in the Galapagos, morphologically ill-defined. Specimens here identified as this species are all epruinose, but unlike pruinose specimens of Squamulea they were not collected on calcareous substrates. Often present between the scattered areoles is a thin, \pm shiny, whitish to blackened hypothallus. It can be particularly well-developed as a black borderline delimiting different incompatible thalli. Such a prothallus has also been observed in some of the other species in the group, particularly $S$. humboldtiana (Fig. 14C shows the two species growing side-by-side).

Specimens examined from Ecuador, Galápagos. FLOREANA: lower S-slope of Cerro Ventanas, $1^{\circ} 16^{\prime} 36^{\prime \prime} \mathrm{S}, 90^{\circ} 25^{\prime} 41^{\prime \prime} \mathrm{W}$, $295 \mathrm{~m}$ alt., transition zone, open shrubland of Macraea laricifolia and some lower Waltheria ovata shrubs in between, on rock, 18-Jan-2011, Bungartz, F. 9857 (CDS 47195); trail from La Primavera Farm to La Corona and Arco de la Reina, southeastern part of the island, $1^{\circ} 19^{\prime} 21^{\prime \prime} \mathrm{S}, 90^{\circ} 24^{\prime} 45^{\prime \prime} \mathrm{W}, 219 \mathrm{~m}$ alt., transition zone, very dense scrub of Clerodendrum molle with some Croton scouleri, Waltheria ovata, few Prosopis juliflora and occasional trees of Geoffroea spinosa in flat area on generally SE-exposed, moderately inclined slope with few boulders, on rock, 24-Jan-2011, Bungartz, F. 10152 (CDS 47571). SAN CRISTÓBAL: hills S of Punta Pit at the NE-coast of the island, $0^{\circ} 43^{\prime} 16^{\prime \prime} \mathrm{S}, 89^{\circ} 14^{\prime} 40^{\prime \prime} \mathrm{W}, 63 \mathrm{~m}$ alt., coastal zone, SSE-exposed ridge of basalt cliff, on rock, 21-Apr-2007, Bungartz, F. 6168 (CDS 34380); crest of Cerro Tortuga, $\sim 4 \mathrm{~km}$ inland from the NW-coast, $0^{\circ} 44^{\prime} 54^{\prime \prime} \mathrm{S}, 89^{\circ} 23^{\prime} 32^{\prime \prime} \mathrm{W}, 116 \mathrm{~m}$ alt., dry zone, open Piscidia carthagenensis woodland with few Bursera graveolens and dense understory of Croton scouleri, Cordia lutea, and Mentzelia aspera on rocky SE-exposed slope of hill, on rock, 25-Apr-2007, Bungartz, F. 6529 (CDS 34747). SANTIAGO: summit of Cerro Gavilan, inner N- and NE-exposed crater rim, $0^{\circ} 12^{\prime} 20^{\prime \prime} \mathrm{S}, 90^{\circ} 47^{\prime} 3^{\prime \prime} \mathrm{W}, 840 \mathrm{~m}$ alt., humid zone, N- and NE-exposed, steep basalt cliffs of crater rim with ferns (Pityrograma calomelanos var. calomelanos, Polypodium tridens, Dryopteris palmata, Adiantum concinnum, Blechnum polypodioides) growing in crevices, on rock, 23-Mar-2006, Aptroot, A. 65718 A (CDS 32310)

Squamulea osseophila Søchting \& Bungartz, sp. nov.

(Figs 3, 15)

MycoBank MB 836958

Diagnosis: A species so far collected only on bone (i.e., 'osseo-philous'), with thalli composed of irregularly convex areoles, barely subsquamulose around their edges, their surface smooth, with a 'waxy', shiny texture, consistently epruinose even though appearing restricted to calcareous substrates (all Galapagos specimens exclusively collected on bone), without a distinct prothallus, apothecia distinctly sessile, disc epruinose, deeper in color than the thallus; (7.6-)8.4-13.3(-17.3) $\times$ (4.4-)5.1-6.6(-7.4) $\mu \mathrm{m}$, with a moderately thickened, (1.7-)2.5$3.6(-4.1) \mu \mathrm{m}$ wide septum $(\mathrm{n}=46)$. The new species is reliably distinguished from other morphologically extremely similar species in Squamulea by its different ITS sequence.

Type: Ecuador, Galápagos: Santiago, summit of Cerro Gavilan, outer S-exposed crater rim, $0^{\circ} 12^{\prime} 23^{\prime \prime} \mathrm{S}, 90^{\circ} 46^{\prime} 57^{\prime \prime} \mathrm{W}$, $840 \mathrm{~m}$ alt., humid zone, S-exposed, steep basalt cliffs of crater rim with ferns (Pityrograma calomelanos var. calomelanos, Polypodium tridens, Dryopteris palmata, Adiantum concinnum, Blechnum polypodioides) growing in crevices, on bone, 23Mar-2006, Aptroot, A. 65489 (CDS 32078-holotype; GenBank Accession number nrITS: MT967455).

Chemistry. Thallus and apothecia $\mathrm{P}-, \mathrm{K}+$ purple, $\mathrm{C}-$, $\mathrm{KC} \pm$ purplish, $\mathrm{UV}-($ dull); thallus and apothecia with a large proportion of parietin and smaller proportions of teloschistin, fallacinal, parietinic acid and emodin (chemosyndrome A sensu Søchting 1997)

Ecology and distribution. Currently, known only from the Galapagos, but most likely not confined to the islands. The few specimens currently known, collected on three different islands, have all been found growing on bone. In the Galapagos, bone is among the few natural substrates that contain calcium carbonate, although only in trace amount compared to calcareous rock, which in the islands only occurs where reefs have been uplifted or as part of artificial substrates (e.g., buildings: concrete, cement, fiber cement).

Etymology. The epithet osseophila indicates that the species is so far only known to be growing on bone.

Notes. Among the Squamulea described here as new, $S$. osseophila is relatively well characterized by its substrate (found only on bone) and, despite growing on this calciferous substrate, nevertheless consistently forming epruinose thalli with a \pm shiny, almost 'waxy' surface 
texture. Phylogenetically, the material analyzed appears to be more closely related to S. flakusii, S. loekoesiana, and S. phyllidizans than to S. subsoluta/squamosa, or the newly described $S$. chelonia, $S$. humboldtiana, and S. oceanica.

Specimens examined. ISABELA, VOLCÁN ALCEDO: upper NNW-exposed slope inside the crater, $0^{\circ} 27^{\prime} 27^{\prime \prime} \mathrm{S}$, $91^{\circ} 7^{\prime} 23^{\prime \prime} \mathrm{W}, 1055 \mathrm{~m}$ alt., humid zone, open vegetation with Adianthus concinnum, and scattered shrubs of Tournefortia rufo-sericea among basalt rocks, on bone, 05-Mar-2006, Aptroot, A. 64900 (CDS 31478). SANTIAGO: summit of Cerro Gavilan, outer S-exposed crater rim, $0^{\circ} 12^{\prime} 23^{\prime \prime} \mathrm{S}, 90^{\circ} 46^{\prime} 57^{\prime \prime} \mathrm{W}$, $840 \mathrm{~m}$ alt., humid zone, S-exposed, steep basalt cliffs of crater rim with ferns (Pityrograma calomelanos var. calomelanos, Polypodium tridens, Dryopteris palmata, Adiantum concinnum, Blechnum polypodioides) growing in crevices, on bone, 23-Mar-2006, Aptroot, A. 65488 A (CDS 42936); Aptroot, A. 65488 A (CDS 42936). SANTA CRUZ: Puerto Ayora, cliff behind Charles Darwin Research Station (CDRS), $0^{\circ} 44^{\prime} 30^{\prime \prime} \mathrm{S}$, $90^{\circ} 18^{\prime} 40^{\prime \prime} \mathrm{W}, 20 \mathrm{~m}$ alt., dry zone, on bone, 18-Feb-2006, Aptroot, A. 64203 (CDS 30769).

Squamulea phyllidizans (Wetmore) Søchting \& Bungartz, comb. nov.

(Figs 3, 14A-B, E-G)

MycoBank MB 836959

Basionym: Caloplaca phyllidizans Wetmore, Bryologist 106(1): 149. 2003; MycoBank MB 489530.

Description. Thallus distinctly subsquamulose to minutely squamulose, individual squamules \pm sub-erect, giving the thallus an almost subfoliose appearance, up to $3 \mathrm{~cm}$ in diam. or confluent, several thalli merging, effuse, not delimited by a prothallus, hypothallus absent; surface smooth, yellowish orange, epruinose to faintly orange pruinose, with abundant, distinct, dense, marginal blastidia. Apothecia mostly sparse, sessile, up to $0.8 \mathrm{~mm}$ in diam., lecanorine; thalline margin slightly prominent and persistent, $\sim 100 \mu \mathrm{m}$ thick, regularly circular, concolorous with the thallus, epruinose, $\mathrm{C}-, \mathrm{K}+$ purple; disc flat, deep orange, darker than the margin, epruinose, $\mathrm{C}-, \mathrm{K}+$ purple; epihymenium with orange pigment granules, $\mathrm{C}+$ red, $\mathrm{K}+$ purple, pigmentation contiguous with the outer exciple, hymenium hyaline, not inspersed; proper exciple absent (completely reduced); thalline exciple differentiated into an inner, hyaline part, a central part with large trebouxioid photobionts, lacking crystals, and an outer, deeply brownish orange part, with abundant pigment granules, $\mathrm{C}+$ red, $\mathrm{K}+$ purple; subhymenium and hypothecium not differentiated, hyaline, not inspersed; asci clavate, Teloschistes-type; ascospores 8/ascus, polaribilocular, oblong to broadly ellipsoid, $(8.3-) 9.7-12.0(-12.8) \times$ (3.7-)5.0-7.1(-8.2) $\mu \mathrm{m}$, with a moderately thickened, $(1.7-) 2.8-4.6(-5.9) \mu \mathrm{m}$ wide septum $(\mathrm{n}=40)$.

Chemistry. Thallus and apothecia $\mathrm{P}-, \mathrm{K}+$ purple, $\mathrm{C}-$, $\mathrm{KC} \pm$ purplish, UV- (dull); thallus and apothecia contain a large proportion of parietin, a smaller proportion of fallacinal and very small proportions of teloschistin, parietinic acid and emodin (chemosyndrome A3 sensu Søchting 1997).
Ecology and distribution. New to South America. Wetmore (2007a) previously reported the species from southwestern North America, including Mexico. In Galapagos, specimens have been found on rock or consolidated volcanic ash, rarely also on bone (carapace of a living tortoise). The species appears to be only moderately common and can typically be found in \pm nitrophytic, dust-rich habitats close to the ground, in the dry, transition and humid zone.

Notes. Squamulea phyllidizans is one of the few species morphologically easily distinguished from the remainder of the squamosa/subsoluta-group, characterized by distinct thallus squamules lined with abundant marginal blastidia (Fig. 14A-B \& E). Only two of the three ITS sequences examined here, however, form a monophyletic group. The third sequence appears as a sister clade to species formerly referred to as 'Huriella', and as a sister group also of $S$. osseophila (Fig. 3). Further studies are necessary to better understand the position of $S$. phyllidizans within the group. Squamosa phyllidizans is not only distinguished by its distinctly squamulose blastidiate thallus, but further characterized by chemosyndrome A3, whereas most specimens of the squamosa/subsoluta-group appear to be characterized by chemosyndrome A.

Specimens examined from Ecuador, Galápagos. ISABELA, VOLCÁN ALCEDO: outer SE-exposed slope, $~ 100 \mathrm{~m}$ below the crater rim, $0^{\circ} 25^{\prime} 36^{\prime \prime} \mathrm{S}, 91^{\circ} 5^{\prime} 12^{\prime \prime} \mathrm{W}, 1146 \mathrm{~m}$ alt., humid zone, disturbed by former grazing of goats, Pteridium arachnoideum and Stachytarpheta cayennensis, scattered low shrubs of Tournefortia rufo-sericea and outcrops of basalt tuff in between, on rock, 06-Mar-2006, Bungartz, F. 4158 (CDS 28189); on crater rim SE of hut, $0^{\circ} 27^{\prime} 35^{\prime \prime} \mathrm{S}, 91^{\circ} 6^{\prime} 43^{\prime \prime} \mathrm{W}, 1080 \mathrm{~m}$ alt., humid zone, tortoise pasture with scattered trees (Tournefortia rufo-sericea, Zanthoxylum fagara), on bone, 05-Mar-2006, Aptroot, A. 64828 (CDS 56109); along the trail going up the E-slope, basalt rubble field to the SE-side of the trail and the barranco, $0^{\circ} 24^{\prime} 7^{\prime \prime} \mathrm{S}, 91^{\circ} 2^{\prime} 55^{\prime \prime} \mathrm{W}$, $493 \mathrm{~m}$ alt., dry zone, basalt rubble field with scattered vegetation (Bursera graveolens, Zanthoxylum fagara, Pisonia floribunda, Senna pistaciifolia), on rock, 10-Mar-2006, Bungartz, F. 4455 (CDS 28541). SANTIAGO: Cerro Gavilan, directly below the summit at the NE-exposed slope, $0^{\circ} 12^{\prime} 19^{\prime \prime} \mathrm{S}, 90^{\circ} 47^{\prime} 6^{\prime \prime} \mathrm{W}, 828 \mathrm{~m}$ alt., humid zone, formerly with scrub or forest, disturbed by former grazing therefore shrubs and trees missing; artificial pampa with Solanum americanum, Portulaca oleraceum, Senna occidentalis, Borreria laevis, and grasses, basalt boulders and outcrops, on rock, 22-Mar-2006, Bungartz, F. 4710 (CDS 28808), 4709 A (CDS 28807), 4711 A (CDS 28809); summit of Cerro Gavilan, inner $\mathrm{N}$ - and NE-exposed crater rim, $0^{\circ} 12^{\prime} 20^{\prime \prime} \mathrm{S}, 90^{\circ} 47^{\prime} 3^{\prime \prime} \mathrm{W}$, $840 \mathrm{~m}$ alt., humid zone, N- and NE-exposed, steep basalt cliffs of crater rim with ferns (Pityrograma calomelanos var. calomelanos, Polypodium tridens, Dryopteris palmata, Adiantum concinnum, Blechnum polypodioides) growing in crevices, on rock, 23-Mar-2006, Aptroot, A. 65729 A (CDS 32321); along the trail from Bucanero to Jaboncillos, $\sim 1 \mathrm{~km}$ below the summit, Cerro Gavilan, $0^{\circ} 11^{\prime} 45^{\prime \prime} \mathrm{S}, 90^{\circ} 47^{\prime} 20^{\prime \prime} \mathrm{W}, 680 \mathrm{~m}$ alt., transition zone, open Psidium galapageium forest with Zanthoxylum fagara, Blainvillea dichotoma, Mentzelia aspera and Senna obtusifolia, basalt boulders and outcrops in between, on rock, 22-Mar-2006, Bungartz, F. 4698 (CDS 28785); Aptroot, A. 65468 (CDS 32057); cinder cone $1 \mathrm{~km}$ SE of James Bay, $0^{\circ} 15^{\prime} 0^{\prime \prime} \mathrm{S}, 90^{\circ} 51^{\prime} 15^{\prime \prime} \mathrm{W}$, $30 \mathrm{~m}$ alt., dry zone, along sides of trench containing the spring on NW side of cinder cone, on consolidated ash, 24-Apr-1971, Pike, L.H. 2619 (OSC 53249). 
Squamulea subsoluta (Nyl.) Arup, Søchting \& Frödén, in Arup, Søchting \& Frödén, Nordic J1 Bot. 31(1): 56. 2013.

[Figs 3, 16A-C (Squamulea aff. squamosa), D-E (Squamulea subsoluta s.1.), F-G (sorediate morphotype)]

MycoBank MB 802121

Basionym: Lecanora murorum var. subsoluta Nyl., Flora, Regensburg 56: 197. 1873; MycoBank MB 604472.

Taxonomic note: The name is here applied in the widest sense. Material includes both specimens that more closely resemble the barely squamulose morphotypes of $S$. subsoluta s.str., as well as others that are distinctly squamulose and thus more closely resemble $S$. aff. squamosa. Although some Galapagos material phylogenetically seems to be part of S. subsoluta s.str., most specimens are part of various different other clades. They cannot presently adequately be assigned to any named taxon within Squamulea.

Description. Thallus very variable, areolate to indistinctly subsquamulose, up to $3 \mathrm{~cm}$ in diam., but several thalli often merging, often confluent, individual areoles flattened to barely convex, edges mostly turned downward, areoles loosely dispersed to aggregating into small groups with few immersed to adnate apothecia, effuse, not delimited by a prothallus, hypothallus absent; surface smooth, \pm waxy, but not shiny, pale yellow orange to deep orange, epruinose; very rarely sorediate; soralia erumpent, $0.1-0.3(-4) \mathrm{mm}$ in diam., occasionally confluent, irregularly extruding deep orange or deep yellow, granular soredia (35-50 $\mu \mathrm{m}$ in diam.). Apothecia numerous, dispersed to \pm aggregated, sometimes crowded, sessile, up to $0.6 \mathrm{~mm}$ in diam., lecanorine; thalline margin persistent, not excluded, slightly prominent, regularly circular, not flexuose, almost level with disc, (40-)60-80 $\mu \mathrm{m}$ thick, concolorous with thallus, epruinose, rarely whitish pruinose in parts, $\mathrm{C}-, \mathrm{K}+$ purple; disc flat to slightly convex, deep orange, darker than the margin, mostly epruinose, rarely faintly whitish pruinose in parts, $\mathrm{C}-, \mathrm{K}+$ purple; epihymenium with orange pigment granules, $\mathrm{C}+$ red, $\mathrm{K}+$ purple, pigmentation contiguous with the outer exciple, hymenium hyaline, not inspersed; proper exciple absent (completely reduced); thalline exciple differentiated into an inner, hyaline part, a central part with large trebouxioid photobionts, lacking crystals (or rarely with very few, small crystals, dissolving in K), and an outer, deeply brownish orange part, with abundant pigment granules, $\mathrm{C}+$ red, $\mathrm{K}+$ purple; subhymenium and hypothecium not differentiated, hyaline, not inspersed, paraplectenchymatous, with large, rounded to \pm angular cells; asci broadly to narrowly clavate, Teloschistes-type; ascospores 8/ascus, polaribilocular, oblong to narrowly or broadly ellipsoid to almost globose often with slight median swelling at the septum, (7.5-)8.4-13.3(-17.3) × (4.0-)5.2-7.0(-7.8) $\mu \mathrm{m}$, with a moderately thickened, (1.7-)2.5-3.9(-5.0) $\mu \mathrm{m}$ wide septum $(\mathrm{n}=90)$. Pycnidia not observed.

Chemistry. Thallus and apothecia $\mathrm{P}-, \mathrm{K}+$ purple, $\mathrm{C}-$, $\mathrm{KC} \pm$ purplish, $\mathrm{UV}-$ (dull); thallus and apothecia contain high proportions of parietin and lesser proportions of teloschistin, fallacinal, parietinic acid and emodin corresponding to chemosyndrome A sensu Søchting (1997); some specimens analyzed correspond to chemosyndrome A3 sensu Søchting (1997) (Table 2).

Ecology and distribution. Squamulea subsoluta, as currently delimited, has a world-wide, cosmopolitan distribution, unlike its similar counterpart Squamulea squamosa (B. de Lesd.) Arup, Søchting \& Frödén, which Wetmore (2003, 2007a) suggests is restricted to southwestern North America. In Galapagos, S. subsoluta s.l. is common throughout all vegetation zones, often growing in nutrient-rich situations and then frequently blackened by cyanobacteria growing in between its thallus areoles.

Notes. Our current phylogenetic analysis (Fig. 3) was unable to clearly resolve the different groups of Squamulea squamosa/subsoluta. Although we included in our analyses numerous specimens also from outside Galapagos (Table 1), the resolution of this group remains taxonomically challenging.

Most specimens cited below belong to the typical morphotype of $S$. subsoluta: their thalli are thin, poorly developed, composed of \pm angular to barely subsquamulose epruinose areoles, without a distinct pro- or hypothallus. Some of these specimens (Fig. 16D-E) appear phylogenetically more closely related to $S$. loekoesiana than to $S$. subsoluta s.str. Morphologically, all specimens are not clearly distinguished from the phylogenetically distinct $S$. chelonia, S. humboldtiana, and S. oceanica.

Few specimens in Galapagos have a more distinct squamulose morphology (Fig. 16A). In our phylogenetic tree, these specimens (labeled 'squamosa 2 \& 3') appear closely related to $S$. squamosa s.str. (Fig. 3). The specimens, however, do not belong to the same clade and as soon as more specimens from a broader geographic range are included the resolution of the phylogenetic tree breaks down; relationships then appear much less clearly resolved. Additional specimens of a much broader scope, including additional genes, are necessary to better understand this group.

Virtually all Galapagos specimens of S. squamosa/ subsoluta s.1. lack soredia. One sorediate collection, however, is assigned here with some hesitation to $S$. squamosa/subsoluta s.l. Nevertheless, the only two specimens (COLO 294630, duplicate at QCA) cannot be considered to be conspecific with $S$. phyllidizans as their morphology clearly does not agree with that species (Fig. 16F-G). The material instead has a deep orange thallus composed of irregularly subsquamulose areoles; it is not distinctly squamulose and only very sparsely sorediate, but not blastidiate. Unfortunately, this historic collection turned out to be too old to yield DNA (specimens collected on 25-Apr-1976 by Weber, W.A. s.n. \& Lanier, J., L-62891, COLO 294630, duplicate at QCA).

Specimens examined from Ecuador, Galápagos. Morphotype of S. subsoluta s.l. - fertile material, lacking soredia: ECUADOR. Galápagos: ISABELA, VOLCÁN ALCEDO:; along the trail going up the E-slope, basalt rubble field to the SE-side of the trail and the barranco, $0^{\circ} 24^{\prime} 6^{\prime \prime} \mathrm{S}, 91^{\circ} 2^{\prime} 53^{\prime \prime} \mathrm{W}$, $530 \mathrm{~m}$ alt., dry zone, basalt rubble field with scattered vegetation (Bursera graveolens, Zanthoxylum fagara, Pisonia floribunda, Senna pistaciifolia), on rock, 10-Mar-2006, Aptroot, 
A. 64940 (CDS 31519). VOLCÁN CERRO AZUL: highest peak with GPS station, atop of the peak, just below the GPS station, $0^{\circ} 55^{\prime} 44^{\prime \prime} \mathrm{S}, 91^{\circ} 24^{\prime} 35^{\prime \prime} \mathrm{W}, 1680 \mathrm{~m}$ alt., high-altitude dry zone, open pasture with dense, humid soil and exposed soil crusts, small elevation near the crater, open place, on rock, 05-May-2012, Spielmann, A.A. 10514 (CDS 51870); outer, lower, densely vegetated slopes of the crater rim, $0^{\circ} 57^{\prime} 1^{\prime \prime} \mathrm{S}$, $91^{\circ} 24^{\prime} 18^{\prime \prime} \mathrm{W}, 1512 \mathrm{~m}$ alt., high altitude transition zone, dense grassy pasture with abundant Low Rattlebox (Crotolaria pumila), scarce Tournefortia rufo-sericea scrub and sparse Psidium galapageium trees, on rock, 05-May-2012, Spielmann, A.A. 10529 (CDS 51886). VOLCÁN DARWIN: southwestern slope, above Tagus Cove, $0^{\circ} 13^{\prime} 27^{\prime \prime} \mathrm{S}, 91^{\circ} 19^{\prime} 21^{\prime \prime} \mathrm{W}, 860 \mathrm{~m}$ alt., transition zone, open scrubland of Dodonaea viscosa, Croton scouleri, Macraea laricifolia, Scalesia microcephala, few Opuntia insularis and dry grasses in the understory, on rock, 15-Nov-2007, Bungartz, F. 7717 (CDS 38219); 1.5 km from the southwestern crater rim, $0^{\circ} 12^{\prime} 20^{\prime \prime} \mathrm{S}, 91^{\circ} 18^{\prime} 52^{\prime \prime} \mathrm{W}, 1280 \mathrm{~m}$ alt., high-altitude dry zone, basalt outcrop bare of vegetation, on rock, 14-Nov-2007, Ertz, D. 11884 (CDS 37243); Bungartz, F. 7594 (CDS 38090). VOLCÁN SIERRA NEGRA: top of the northern crater rim, $0^{\circ} 48^{\prime} 3^{\prime \prime} \mathrm{S}, 91^{\circ} 5^{\prime} 25^{\prime \prime} \mathrm{W}, 968 \mathrm{~m}$ alt., humid zone, SW-exposed basalt cliffs among dry vegetation of grasses and herbs, on rock, 08-Sep-2007, Bungartz, F. 6779 (CDS 36198); Muro de las Lagrimas W of Puerto Villamil, along the stairs going up behind the wall, $0^{\circ} 57^{\prime} 52^{\prime \prime} \mathrm{S}, 91^{\circ} 0^{\prime} 46^{\prime \prime} \mathrm{W}, 78 \mathrm{~m}$ alt., dry zone, dry zone vegetation with Bursera graveolens and Opuntia echios, slope $45^{\circ} \mathrm{N}$, on rock, 17-Aug-2008, Herrera-Campos, M.A. 10738 (CDS 40476). SAN CRISTÓBAL: Pan de Azúcar, inland from Bahía Sardinas at the NW-coast of the island, $0^{\circ} 43^{\prime} 13^{\prime \prime} \mathrm{S}, 89^{\circ} 21^{\prime} 14^{\prime \prime} \mathrm{W}, 155 \mathrm{~m}$ alt., dry zone, E- to SE-exposed cliff at E-facing slope of the hill, on rock, 24-Apr-2007, Bungartz, F. 6438 (CDS 34653); Cerro Colorado, enclosure for Calandrinia galapagosa near the viewpoint on the top, $0^{\circ} 54^{\prime} 58^{\prime \prime} \mathrm{S}, 89^{\circ} 26^{\prime} 5^{\prime \prime} \mathrm{W}, 130 \mathrm{~m}$ alt., transition zone, open scrubland with Croton scouleri, Macraea laricifolia, Calandrinia galapagosa, Lecocarpus darwinii and few trees of Piscidia carthagenensis among lava boulders on SE-exposed slope of cinder cone, on rock, 29-Apr-2007, Bungartz, F. 6706 (CDS 34950). FLOREANA: trail going to Post Office Bay off the dirt road between highlands and Puerto Velasco Ibarra, $1^{\circ} 16^{\prime} 57^{\prime \prime} \mathrm{S}, 90^{\circ} 26^{\prime} 41^{\prime \prime} \mathrm{W}, 310 \mathrm{~m}$ alt., transition zone, open shrubland of Croton scouleri, Zanthoxylum fagara, Macraea laricifolia, Waltheria ovata and lava rocks; Ramalina usneal anceps forming long curtains hanging from branches, on rock, 14-Jan-2011, Bungartz, F. 9578 (CDS 46857); trail from La Primavera Farm to La Corona and Arco de la Reina, southeastern part of the island, $1^{\circ} 19^{\prime} 21^{\prime \prime} \mathrm{S}, 90^{\circ} 24^{\prime} 45^{\prime \prime} \mathrm{W}, 219 \mathrm{~m}$ alt., transition zone, very dense scrub of Clerodendrum molle with some Croton scouleri, Waltheria ovata, few Prosopis juliflora and occasional trees of Geoffroea spinosa in flat area on generally SE-exposed, moderately inclined slope with few boulders, on rock, 24-Jan-2011, Bungartz, F. 10153 (CDS 47572).

Morphotype of S. subsoluta s.l. - Sorediate material, lacking apothecia: FLOREANA: trail from Black Beach to highlands, 25-Apr-1976, Weber, W.A. s.n. (L-62891, COLO 294630); along trail from Black Beach to Cruz farm, on rock, 25-Apr-1976, Weber, W.A. s.n. (CDS 10849), s.n. (QCA).

Morphotype close to $S$. squamosa s.str. (S. 'squamosa 2 \& 3'): ISABELA, VOLCÁN ALCEDO: outer E-exposed slope just below the crater rim, $0^{\circ} 25^{\prime} 17^{\prime \prime} \mathrm{S}, 91^{\circ} 5^{\prime} 8^{\prime \prime} \mathrm{W}, 1077 \mathrm{~m}$ alt., humid zone, basalt outcrops, SE-exposed slope with scattered shrubs of Tournefortia rufo-sericea, Opuntia insularis, Lantana peduncularis and occasional trees of Zanthoxylum fagara among basalt rubble, on rock, 08-Mar-2006, Aptroot, A. 65167 (CDS 31751). ISABELA, VOLCÁN DARWIN: southwestern slope, above Tagus Cove, $0^{\circ} 13^{\prime} 43^{\prime \prime} \mathrm{S}, 91^{\circ} 19^{\prime} 47^{\prime \prime} \mathrm{W}, 724 \mathrm{~m}$ alt., transition zone, SW-exposed lava flow of weathered AA-lava with scarce vegetation (Macraea laricifolia, Dodonaea viscosa, Croton scouleri, Cordia revoluta and Jasminocereus thouarsii), on rock, 12-Nov-2007, Bungartz, F. 7428 (CDS 37915).

Material close to $S$. loekoesiana (S. 'squamosa 1'): SANTIAGO: summit of Cerro Gavilan, outer S-exposed crater rim, $0^{\circ} 12^{\prime} 23^{\prime \prime} \mathrm{S}, 90^{\circ} 46^{\prime} 57^{\prime \prime} \mathrm{W}, 840 \mathrm{~m}$ alt., humid zone, S-exposed, steep basalt cliffs of crater rim with ferns (Pityrograma calomelanos var. calomelanos, Polypodium tridens, Dryopteris palmata, Adiantum concinnum, Blechnum polypodioides) growing in crevices, on lava rock, Aptroot, A. 65480 (CDS 32069).

\section{New combination in Squamulea not reported from the Galapagos}

Squamulea loekoesiana (S.Y. Kondr. \& Upreti) Arup, Søchting \& Bungartz, comb. nov.

MycoBank MB 836960

Basionym: Huriella loekoesiana S.Y. Kondr. \& Upreti, Acta Botanica Hungarica 59: 102. 2017; MycoBank MB 819646.

Xanthomendoza S.Y. Kondr. \& Kärnefelt, Progr. Probl. Lichenol. Nineties. Proc. Third Symp. Intern. Assoc. Lichenol., Biblthca Lichenol. 68: 26. 1997.

MycoBank MB 27731

Xanthomendoza leoncita Bungartz \& Søchting, sp. nov. (Figs 4, 18F-G)

\section{MycoBank MB 836963}

Diagnosis: A corticolous, foliose species with narrow, shortly elongate, very minute lobes, $0.1-0.3 \mathrm{~mm}$ wide, apically broadened to $0.5 \mathrm{~mm}$, the upper side deep yellow to deep orange, the lower surface white to pale yellow, with few cilia (marginal rhizines), attached with hapters or short, scarce rhizines, soralia pustulate-capitate, mostly apical, rarely submarginal.

Type: Ecuador, Galápagos: Isabela, Volcán Alcedo, along the trail going up the E-slope, basalt rubble field to the SEside of the trail and the barranco, $0^{\circ} 24^{\prime} 3^{\prime \prime} \mathrm{S}, 91^{\circ} 2^{\prime} 35^{\prime \prime} \mathrm{W}, 434 \mathrm{~m}$ alt., dry zone, basalt rubble field with scattered vegetation (Bursera graveolens, Zanthoxylum fagara, Pisonia floribunda, Senna pistaciifolia), on bark, 09-Mar-2006, Bungartz, F. 4417 (CDS 28502-holotype; GenBank Accession number nrITS: MT967476).

Description. Thallus minutely foliose, forming small to medium-sized, \pm coralloid rosettes or small mats of stout, sub-erect, anisotomically branched lobes; lobes dorsiventral, mostly convex, narrow, shortly elongate, $0.1-0.3 \mathrm{~mm}$ wide, slightly broadening at their flattened, \pm truncate apex (up to $0.5 \mathrm{~mm}$ wide); lobe margin rarely with very few cilia (= marginal rhizines); upper surface deep yellow to deep orange, smooth, epruinose, dull to \pm shiny; lower surface white to pale yellow, \pm wrinkled, attached by few, sparse hapters (or short rhizines); soralia mostly apical, occasionally submarginal, pustulate-capitate, $\sim 0.1-0.2 \mathrm{~mm}$ broad, with coarse, granular-blastidiate yellowish to bright orange, in parts \pm greenish soredia, (24-)26-37(-40) $\mu \mathrm{m}$ in diam. Apothecia unknown. Pycnidia unknown. 
Chemistry. Thallus and apothecia $\mathrm{P}-, \mathrm{K}+$ purple, $\mathrm{C}-$, $\mathrm{KC} \pm$ purplish, $\mathrm{UV}-$ (dull); thallus and apothecia contain a large proportion of parietin, a smaller proportion of fallacinal and very small proportions of teloschistin, parietinic acid and emodin (chemosyndrome A3 sensu Søchting 1997).

Ecology and distribution. Known only from the Galapagos, where it is a relatively rare species. It is most common throughout the dry zone, occasionally also in the transition zone, rarely in the humid zone (Cerro Gavilan, Santiago). Typically, it grows on bark (often on Pisonia floribunda, less frequently on Bursera graveolens or Piscidia carthagenensis), but there are also two specimens from rock.

Etymology. The epithet leoncita means little lion in Spanish and the golden orange rosettes recall a lion's mane; incidentally, the name is also a nickname of the first author's daughter Lea. It is thus used as a noun in apposition.

Notes. Compared to other species in the genus, Xanthomendoza leoncita has unusually minute lobes, almost as small as those of Polycauliona tenuiloba (known only from the Sonoran Region). That species, however, has an overall grayish white to very pale yellow thallus, never deep yellow or orange. Although lobes of $X$. leoncita have the tendency to grow slightly erect, often forming small mats, its individual lobes appear more distinctly flattened and not as 'terete' as those of Polycauliona candelaria, which typically forms \pm coralloid cushions. Habitually, X. leoncita also resembles Polycauliona adscendens, which, however, has much wider lobes with helmet-shaped tips. The species is described here as a Xanthomendoza, because specimens typically have at least some, though often only few cilia or short rhizines. Unfortunately, conidiomata were not observed, but the molecular results also suggest the species belongs in Xanthomendoza, not in Polycauliona, and seems to be closely related to $X$. weberi (Fig. 4).

Specimens examined from Ecuador, Galápagos. ISABELA, VOLCÁN ALCEDO: along the trail going up the E-slope, basalt rubble field to the SE-side of the trail and the barranco, $0^{\circ} 24^{\prime} 3^{\prime \prime} \mathrm{S}, 91^{\circ} 2^{\prime} 35^{\prime \prime} \mathrm{W}, 434 \mathrm{~m}$ alt., dry zone, basalt rubble field with scattered vegetation (Bursera graveolens, Zanthoxylum fagara, Pisonia floribunda, Senna pistaciifolia), on bark, 09-Mar-2006, Bungartz, F. 4417 (CDS 28502); along the trail going up the E-slope, basalt rubble field to the SE-side of the trail and the barranco, $0^{\circ} 24^{\prime} 7^{\prime \prime} \mathrm{S}, 91^{\circ} 2^{\prime} 55^{\prime \prime} \mathrm{W}, 493 \mathrm{~m}$ alt., dry zone, basalt rubble field with scattered vegetation (Bursera graveolens, Zanthoxylum fagara, Pisonia floribunda, Senna pistaciifolia), on bark, 10-Mar-2006, Bungartz, F. 4449 (CDS 28535); basalt rubble field to the SE-side of the trail and the barranco, $0^{\circ} 24^{\prime} 6^{\prime \prime} \mathrm{S}, 91^{\circ} 2^{\prime} 53^{\prime \prime} \mathrm{W}, 530 \mathrm{~m}$ alt., dry zone, basalt rubble field with scattered vegetation (Bursera graveolens, Zanthoxylum fagara, Pisonia floribunda, Senna pistaciifolia), on bark, 10-Mar-2006, Aptroot, A. 64925 (CDS 31504), 64946 (CDS 31525). VOLCÁN DARWIN: southwestern slope, above Tagus Cove, $0^{\circ} 14^{\prime} 15^{\prime \prime} \mathrm{S}, 91^{\circ} 20^{\prime} 40^{\prime \prime} \mathrm{W}, 351 \mathrm{~m}$ alt., dry zone, open Bursera graveolens forest with Croton scouleri, Macraea laricifolia and Waltheria ovata, few trees of Acacia rorudiana, on bark, 16-Nov-2007, Bungartz, F. 7903 (CDS 38412). VOLCÁN WOLF: NW-coast between Punta Isabela and Volcán Ecuador, dry zone, on bark, 07-May-1976, Weber, W.A. s.n. (L-63261,
COLO 296854). SANTA CRUZ: along old trail from Puerto Ayora (Academy Bay) to Bella Vista, $80 \mathrm{~m}$ alt., dry zone, on bark, 11-Apr-1976, Weber, W.A. s.n. (L-63323, COLO 297098); vicinity of Academy Bay, top of first barranca along old trail, dry zone, 15-Feb-1964, Weber, W.A. s.n. (L-40564, COLO 192475); dry zone, cactus forest, on bark, 15-Feb-1964, Weber, W.A. s.n. (L-40361, COLO 188566); along old trail to Bella Vista, transition zone, on bark, 29-Apr-1976, Weber, W.A. s.n. (CDS 10866), s.n. (QCA); near begin of old trail to Baltra, $0^{\circ} 44^{\prime} 12^{\prime \prime} \mathrm{S}$, $90^{\circ} 19^{\prime} 11^{\prime \prime} \mathrm{W}, 25 \mathrm{~m}$ alt., dry zone, 19-Mar-2006, Aptroot, A. 65301 (CDS 31887). SANTIAGO: summit of Cerro Gavilan, inner $\mathrm{N}$ - and NE-exposed crater rim, $0^{\circ} 12^{\prime} 20^{\prime \prime} \mathrm{S}, 90^{\circ} 47^{\prime} 3^{\prime \prime} \mathrm{W}$, $840 \mathrm{~m}$ alt., humid zone, N- and NE-exposed, steep basalt cliffs of crater rim with ferns (Pityrograma calomelanos var. calomelanos, Polypodium tridens, Dryopteris palmata, Adiantum concinnum, Blechnum polypodioides) growing in crevices, on rock, 23-Mar-2006, Aptroot, A. 65669 (CDS 32260).

\section{New synonyms in Xanthomendoza not reported from the Galapagos}

Xanthomendoza mendozae (Räsänen) S.Y. Kondr. \& Kärnefelt, Progr. Probl. Lichenol. Nineties. Proc. Third Symp. Intern. Assoc. Lichenol., Biblthca Lichenol. 68: 26. 1997.

\section{MycoBank MB 442646}

Basionym: Xanthoria mendozae, Räsänen, Anal. Soc. cient. argent. 128(3): 140. 1939; MycoBank MB 371933.

New Synonym: Xanthomendoza kashiwadanii S.Y. Kondr. \& Kärnefelt, in Kondratyuk, Kärnefelt, Elix \& Thell, Biblthca Lichenol. 100: 275. 2009; MycoBank MB 540875.

Xanthomendoza ulophyllodes (Räsänen) Søchting, Kärnefelt \& S.Y. Kondr., Mitt. Inst. Allg. Bot. Hamburg 30-32: 238. 2002.

\section{MycoBank MB 373384}

Basionym: Xanthoria ulophyllodes Räsänen, Die Flecht. Estl. 1: 105. 1931; MycoBank MB 410049.

New Synonyms: Xanthomendoza soechtingii (S.Y. Kondr.) Kärnefelt \& S.Y. Kondr., in Søchting, Kärnefelt \& Kondratyuk, Mitt. Inst. Allg. Bot. Hamburg 30-32: 238. 2002; MycoBank MB 373386. Xanthoria soechtingii S.Y. Kondr. [as 'soechtingi'], J. Hattori bot. Lab. 89: 261. 2000; MycoBank MB 482989.

Xanthomendoza weberi (S.Y. Kondr. \& Kärnefelt) L. Lindblom, Bryologist 109(1): 5. 2006.

MycobBank No. MB 516908

Basionym: Xanthoria weberi SY. Kondr. \& Kärnefelt, Ukrainskiy Botanichnyi Zhurnal 60(2): 126. 2003; MycoBank MB 529428.

New synonym: Xanthoria wetmorei S.Y. Kondr. \& Kärnefelt [as 'wetmori'] Ukrainskiy Botanichnyi Zhurnal 60(2): 128. 2003; MycoBank MB 529429.

\section{New combination in Loekoesia, a genus not reported from the Galapagos}

Loekoesia yuchiorum (Lendemer \& C. A. Morse) Arup \& Søchting, comb. nov.

MycoBank MB 836964 
Basionym: Caloplaca yuchiorum Lendemer \& C. A. Morse, Journal of the Torrey Botanical Society 137: 328. 2010; MycoBank MB 518412.

Taxonomic Note: The genus Loekoesia was erected to accommodate one single species, L. austrocoreana (S.Y. Kondr. Lökös \& Hur) S.Y. Kondr. et al. (Kondratyuk et al. 2015). Loekoesia austrocoreana and L. yuchiorum show great similarities in morphology, anatomy and probably also chemistry (atranorin in thallus, but lacking anthraquinones) and the combined analysis clearly shows that they are close relatives. Loekoesia yuchiorum has smaller spores and grows in inland localities in the USA and L. austrocoreana on seashore rocks in South Korea.

\section{Key to the species}

Thallus foliose, subfruticose or distinctly fruticose; adhered to the substrate by a central holdfast, hapters or rhizines, either developing dorsiventral lobes with a distinct upper and lower side, or forming \pm terete to irregular branches.................. Thallus crustose; almost entirely adhered to the substrate, no distinct lower surface (leprose, rimose, areolate, placodioid-lobate, subsquamulose, or squamulose) . . . . 4 4

2 Thallus minutely foliose, forming small rosettes or mats of \pm suberect lobes adhered by sparse hapters or short rhizines; with apical, pustulate-capitate soralia, extruding coarse, blastidiate soredia; apothecia unknown. ..... .

Xanthomendoza leoncita

Thallus subfruticose to fruticose, forming small or large tufts of elongate, irregularly terete to \pm flattened branches, growing either from a distinct central holdfast or loosely and irregularly attached, but not forming hapters or rhizines; soralia, if present, mostly marginal, if apical, not distinctly capitate; apothecia numerous, sparse or absent (Teloschistes) . . . . . . . . . . . . . . 3

3 Thallus typically with abundant apothecia; branches \pm flattened and indistinctly dorsiventral, i.e., with a deeply colored upper side and a pale lower side; tufts relatively small and \pm prostrate; cilia not darkened at their tip; soralia not known from the Galapagos specimens .... ............ Teloschistes chrysophthalmus

Thallus very rarely producing apothecia; branches irregularly terete, not dorsiventral, i.e., not flattened, not distinctly differentiated into an upper and lower side; tufts often large, irregularly erect; cilia often darkened or even blackened at their tips; abundantly sorediate. ....... .

Teloschistes flavicans

4(1) Thallus leprose, i.e., entirely dissolved into deep yellow to orange, coarse, pseudocorticate granules ........ .................. Leproplaca chrysodeta

Thallus not leprose, not entirely dissolved into granules, but several species are densely isidiate or abundantly sorediate, with propagules developing from a distinct thallus or at least a conspicuous hypothallus......5

5 Apothecia pallid (flesh-colored), in parts grayish, turning deep wine-red, brown or blackened throughout, $\mathrm{K}$ - (anthraquinones absent) ................. 6 Apothecia absent or, if present, yellow to brownish orange or rust red, $\mathrm{K}+$ purple (with anthraquinones).......9 gin; thallus rimose, pale creamy white to beige, on

a conspicuously blackened hypothallus; corticolous. . . Phaeoplaca tortuca

Apothecia pallid (flesh-colored), deep wine-red or black; thallus rimose to areolate, light to dark gray or brownish olive; corticolous or saxicolous . . . . . . . . . . . 7

Thallus pale whitish gray, typically sorediate; young apothecia pallid (flesh-colored), soon becoming discolored, at least in parts grayish to deeply wine-red, almost blackened throughout, adnate, often \pm convoluted and deforming one another, 'gall-forming'; mostly saxicolous, rarely corticolous . . . . . . Sucioplaca diplacia

Thallus dark gray or olivaceous, lacking soredia; apothecia deep black throughout, never pallid, immersed to sessile, distinctly separate, not deforming one another; corticolous or saxicolous . . . . . . . . . . . 8

Thallus rimose, dark gray, corticolous; apothecia sessile, distinctly lecideine . . . . . . . Caloplaca floridana

Thallus areolate, brownish olive, saxicolous; apothecia initially immersed, \pm aspicilioid, adnate to sessile with age and then appearing \pm lecideine .. Caloplaca nigra

9(5) Thallus gray or whitish, lacking yellow or orange pigmentation, $\mathrm{K}-$ (anthraquinones absent) . . . . . . 10 Thallus with yellow to orange pigmentation, $\mathrm{K}+$ purple (with anthraquinones) ................. 17

10 Thallus always with vegetative propagules (isidia or soredia), rarely fertile............... 11 Thallus lacking vegetative propagules (isidia or soredia), typically fertile ................. 15

11 Thallus surface with distinctly delimited, punctiform to circular soralia; apothecia, if present, pallid (fleshcolored), in part discolored, deep wind-red or almost blackened, K- (lacking anthraquinones, see dichotomy 6) ................. Sucioplaca diplacia Thallus surface isidiate to granular isidiate, or blastidiate throughout; apothecia, if present, orange to rust red, $\mathrm{K}+$ purple ....................... 12

Thallus pale, whitish beige; isidia distinctly coralloid, mature isidia loosely branched ... Huneckia wrightii

Thallus pale bluish gray to dark olive-gray; isidia coarsely granular to minutely granular-blastidiate or densely coralloid, but not loosely branched............ 13

13 Thallus pale bluish gray, distinctly pruinose, coarsely granular isidiate; apothecial disc deep orange, but not rust colored, with a thick, undulate to crenate thalline margin, of the same color or slightly paler than the disc......

. Oceanoplaca chemoisidiosa

Thallus dark olive gray, epruinose, minutely granular to densely coralloid isidiate; apothecial disc deep orange to rusty orange, the thalline margin of the same color as the thallus ....................... 14

Proper margin reduced to a thin dark line between disc and thalline margin, $\mathrm{C}-$; thallus rimose-areolate to squamulose, the surface minutely granular isidiate, isidia occasionally breaking into blastidiate soredia; saxicolous or, less commonly, corticolous................ .... Oceanoplaca sideritoides (isidiate morphotype) Proper margin thick, concolorous with the disc, $\mathrm{C}+$ red; thallus rimose to rimose-areolate, granular to densely coralloid isidiate; mostly corticolous, very rarely saxicolous . .

Lacrima aphanotripta 
15(10) Apothecial disc delimited by a thin, but distinct dark olive to blackish rim (proper margin), at the outside additionally surrounded by a paler, dull olive gray thalline margin. .............. Oceanoplaca sideritoides

(non-isidiate morphotype)

Apothecial disc surrounded by a thick thalline margin; proper margin absent or inconspicuous . . . . . . 16

16 Apothecial disc deep orange; thalline margin thick, of the same color, but slightly paler than the disc, undulate to crenate, at least in parts distinctly whitish pruinose; thallus bullate to subsquamulose areolate, in part almost granular isidiate, pale to dark bluish gray, typically with a whitish pruina ....... Oceanoplaca chemoisidiosa

Apothecial disc dark rust-red, thalline margin concolorous with the disc, rarely pale yellow and in part concolorous with the thallus (especially immature apothecium initials); rimose-areolate to \pm granular, but not subsquamulose, not isidiate, dark gray to brownish gray, epruinose. . . . . ....... Lacrima galapagoensis

17(9) Thallus placodioid, areolate in the center, with distinctly radiating, marginal lobes . . . . . . . . . . 18

Thallus not placodioid, areolate to subsquamulose, if lobate not distinctly radiating. . . . . . . . . . . 19

18 Marginal lobes broadly flattened, central thallus areoles abundantly covered with coarse papillae, which occasionally break apart into bright yellow-orange, blastidiate soralia; apothecia not observed among Galapagos specimens . . . . . . . . . . Wetmoreana brouardii

Marginal lobes \pm convex, central thallus areoles abundantly covered by granular to coralloid isidia, not breaking apart; Galapagos specimens occasionally with apothecia................ Oceanoplaca isidiosa

19(17) Thallus lacking vegetative propagules (no isidia, blastidia, or soredia), always fertile* .......... 20

* (Squamulea: difficult group with highly variable thallus morphology; taxa cannot reliably be distinguished without molecular analysis; key below based on predominant characteristics of Galapagos specimens only!)

Thallus with vegetative propagules, with or without apothecia...................... 26

20 Areoles epruinose, mostly flattened, at least in parts distinctly squamulose to sublobate...........21

Areoles pruinose or epruinose, flattened or convex, mostly angular to barely subsquamulose .......22

21 Thallus of scattered to aggregated, sublobate rosettes ..................... Squamulea flakusii

Thallus of loosely dispersed to closely aggregated squamulose areoles .........S. squamosa/subsoluta s.l. (morphotype of $S$. squamosa s.str.)

22 Thallus areoles angular, barely to strongly convex or almost bullate, not distinctly subsquamulose; frequently on calciferous substrates in nitrophytic habitats . . . 23

Thallus areoles angular to indistinctly subsquamulose; typically on lava .....................24

23 Marginal and central areoles irregularly convex, barely subsquamulose along the edges; thallus surface epruinose, with a 'waxy', shiny texture; apothecia distinctly sessile; currently known only from bone.

S. osseophila
Marginal areoles moderately to strongly convex or even bullate, edges turned downward; central areoles \pm flattened, angular; thallus surface often coarsely pruinose (especially if growing on calciferous substrates such as concrete, fiber cement, or bone; specimens on lava lack pruina); apothecia immersed to adnate; found on a variety of substrates . . . . . . . . . S humboldtiana

24 Thallus areoles typically widely dispersed; surface consistently epruinose; growing typically on a faint, thin, \pm shiny, whitish to blackened hypothallus, in some specimens distinctly separating several thalli as a distinctly blackened prothallus..............S. oceanica

Thallus areoles at least in the thallus center mostly aggregated; surface typically epruinose, but occasionally pruinose (if found on calcareous substrates); prothallus or hypothallus absent .................25

25 Apothecia immersed to adnate; disc distinctly deeper in color than the surrounding areoles.......S. chelonia

Apothecia adnate to soon sessile; disc slightly deeper to almost concolorous with the areoles ...........

S. squamosa/subsoluta s.1. (morphotype of S. subsoluta s.str.)

26(19) Thallus very densely granular to coralloid isidiate, apothecia, if present, rust red; corticolous. . . . . . . . . . ....................... Lacrima epiphora

Thallus not isidiate, with soredia or blastidia; saxicolous . . . . . . . . . . . . . . . . . . . . 27

27 Thallus yellow orange, distinctly squamulose to almost subfoliose; squamules with abundant, marginal, lipshaped, coarsely blastidiate soralia . ........... ................. Squamulea phyllidizans

Thallus chrome yellow to deep orange, central areoles angular and \pm convex, marginal areoles irregularly subsquamulose, \pm convex to barely flattened; soralia laminal, punctiform to \pm circular . . . . . . . . . . . . . 28

28 Thallus deep orange, central areoles \pm convex, irregularly aggregated or dispersed, marginal areoles \pm convex, irregularly subsquamulose; soralia irregularly extruding soredia, not excavate or crateriform, in parts occasionally confluent, with deep orange or deep yellow soredia, of the same color or slightly paler than the thallus, not bright sorediate form of . ........... ........... Squamulea squamosa/subsoluta s.l.

Thallus chrome yellow, central areoles flattened and closely contiguous, marginal areoles flattened and distinctly subsquamulose; soralia moderately excavate to deeply crateriform ('cupuliform'), with coarse, bright yellow soredia, conspicuously brighter than the chrome yellow thallus . . . . ......... Caloplaca cupulifera

\section{Doubtful and incorrect reports}

\section{Caloplaca byrsonimae (Malme) Zahlbr.}

Reports by Weber (1986) and Elix \& McCarthy (1998) refer to Lacrima epiphora.

\section{Caloplaca camptidia (Tuck.) Zahlbr.}

Reports by Weber (1986) and Elix \& McCarthy (1998) refer to the newly described Phaeoplaca tortuca. 
Caloplaca cerina (Ehrh. ex Hedw.) Th. Fr.

A single specimen collected by Reverend T. Hill during the Hassler Expedition 1872 (FH-Tuck 259998), identified by C.M. Wetmore in June 1993 as C. cerina s.l. is most probably erroneously labeled; like several other specimens collected by Hill during that expedition this specimen was not likely collected in the Galapagos.

Caloplaca cirrochroa (Ach.) Th. Fr.

Reported by Weber (1986) and subsequently Elix \& McCarthy (1998) based on misidentifications of Caloplaca cupulifera and/or a sorediate morphotype of Caloplaca subsoluta s.1. (Weber, W.A. s.n. \& Lanier, J., L-62891, COLO 294630).

\section{Caloplaca chlorina (Flot.) Sandst.}

Records previously published online under this name (Bungartz et al. 2016) are based on misidentifications of the isidiate morphotype of the newly described Oceanoplaca sideritoides.

\section{Caloplaca elegans (Link) Th. Fr.}

According to Weber (1986) erroneous reports of 'Caloplaca' (= Oceanoplaca) isidiosa.

Caloplaca ferruginea (Huds.) Th. Fr.

A specimen in COLO (Weber, W.A. s.n., L-40827, COLO 190227) has been annotated by Weber as Caloplaca ferruginea agg., but this record was never published. The specimen belongs to the newly described Oceanoplaca sideritoides.

Caloplaca murorum (Hoffm.) Th. Fr.

First cited in Weber (1966) based on records of Placodium murorum (see below) reported by Stewart (1912); according to Weber (1986) misidentifications of 'Caloplaca' (=Oceanoplaca) isidiosa.

\section{Caloplaca muelleri (Vain.) Zahlbr.}

First reported from the Galapagos by Dodge (1936) based on a specimen collected during the Hancock Expedition 1934 (Taylor, W.R. 874b, included in the same packet as FH 197443). Weber (1986) rejected the report as misidentification of 'Caloplaca' (= Oceanoplaca) isidiosa.

Caloplaca obscurella (J. Lahm ex Körb.) Th. Fr.

Aptroot identified an extremely poorly developed specimen collected on bark as this taxon (Aptroot, A. 65096, CDS 31678; handwritten annotation). The record was never published and the identity of the material remains unresolved.

\section{Caloplaca rugulosa (Nyl.) Zahlbr.}

First reported from the Galapagos by Dodge (1936) based on a specimen collected during the Hancock Expedition 1934 (Taylor, W.R. 859). Weber (1986) did not find the specimen on which this record is based; possibly a misidentification of 'Caloplaca' (= Oceanoplaca) isidiosa.

\section{Caloplaca saxicola (Hoffm.) Nordin}

Records of this species from the Galapagos were never published; they refer to material originally identified by Weber as this taxon, because it is fertile, less abundantly isidiate and frequently \pm pruinose. Here these specimens are treated as part of Oceanoplaca isidiosa.

Caloplaca sideritis (Tuck.) Zahlbr.

Non-isidiate specimens of the newly described Oceanoplaca sideritoides were previously included in the online checklist (Bungartz et al. 2016) under this name.

\section{Placodium murorum (Ach.) DC}

First reported by Stewart (1912); according to Weber (1986) based on erroneous reports of Oceanoplaca isidiosa.

\section{Polycauliona candelaria (L.) Th. Fr.}

Erroneous reports of the newly described Xanthomendoza leoncita; first reported by Weber (1986) and Elix \& McCarthy (1998) under the name Xanthoria candelaria (L.) Th. Fr.

\section{Teloschistes exilis (Michx.) Vain.}

First reported by Dodge (1936), subsequently cited also by Weber (1966), but subsequently considered an erroneous identification of T. flavicans (Weber 1986). We agree with Weber's assessment: the specimen in FH annotated by Dodge (Taylor, W.R. 865, FH 197409) is indeed sorediate and sterile.

\section{Xanthomendoza weberi (S.Y. Kondr. \& Kärnefelt) L. Lindblom}

Previously included in the online checklist (Bungartz et al. 2016); the record refers to the newly described Xanthomendoza leoncita.

\section{Acknowledgements}

On occasion of his $65^{\text {th }}$ birthday, we dedicate this publication to our friend and colleague Philippe Clerc for his life's work in lichenology, particularly his tremendous contribution to the taxonomy of the genus Usnea, not only in the Galapagos, but globally. The Galapagos lichen inventory would not be possible without Frauke Ziemmeck, who for many years managed the cryptogam collection at CDS. André Aptroot contributed many important specimens to the lichen herbarium of the research station in the Galapagos, among the specimens much of the material of the Teloschistaceae examined here; we especially want to acknowledge this contribution by naming $P$. tortuca in his honor (see Etymology of this species' name). We further acknowledge support by successive CDF science directors (Alan Tye, Mark Gardener, Rodolfo Martinez, Ulf Härdter, Noëmi d'Ozouville, Heinke Jäger, and most recently Maria-José Barragan Paladines) and are indebted to the Directorate of the Galapagos National Park (DPNG). The Galapagos Lichen Inventory is now part of the national biodiversity assessment 'Biodiversidad Genética del Ecuador', led by the Instituto Nacional de Biodiversidad del Ecuador (INABIO). For research and specimen permits we are particularly indebted to Danny Rueda, Daniel Lara Solís, Galo Quedaza and Victor Carrión from DPNG, and Diego Inclán, Francisco Prieto and Rosa Batallas (INABIO). The Census 
of Galapagos Biodiversity and the CDF Checklist of Galapagos Species received several grants (donors and contributing scientists cited at http://www.darwinfoundation.org/datazone/ checklists/). The assistance of Lisbeth Knudsen (University of Copenhagen) for molecular and chemical analyses is highly appreciated; John A. Elix made valuable comments on some of the chemical results. Most of these analyses were carried out during a 2011 visit in Copenhagen by the first author (FB), who would like to thank Ulrik Søchting for his hospitality. We much appreciate how Konstanze Bensch helped to resolve some difficult nomenclatural aspects. We much appreciate the constructive criticism that we received from two anonymous reviewers. Elizabeth Makings, Christian Parrinello, and Camille Truong helped editing the final version, catching numerous errors and suggesting stylistic changes which much improved the text. As authors, we are entirely to blame for any additional mistakes that we might still have overlooked. The lichen inventory received funds from The Paul and Bay Foundations, and the Erwin Warth Stiftung. An international workshop was supported 2010 by the US National Science Foundation (DEB 0715660, PI Robert Lücking; DEB 0841405, PI James Lawrey, local coordinator F. Bungartz). Taxonomic research with the objective to publish an IUCN red-list of endemic Galapagos lichens is funded by the Mohamed bin Zayed Species Conservation Fund (project 152510692). The Galapagos lichen herbarium is indebted to the curators of: $\mathrm{B}, \mathrm{COLO}, \mathrm{CAS}, \mathrm{FH}, \mathrm{H}$, and $\mathrm{S}$. A visit to FH by the first author (FB) in 2009 was generously supported by a Friends of the Farlow Fellowship. Specimens at BM in London were recently studied with a SYNTHESYS grant to the first author (FB), who is much indebted to the BM curator at the time, Holger Thüs. This is contribution no. 2362 of the Charles Darwin Foundation for the Galapagos Islands.

\section{References}

Ahti, T., Kondratyuk, S. Y., Kärnefelt, I. \& Thell, A. 2015. Nomenclatural corrections and notes on some taxa in the Teloschistaceae (lichenized ascomycetes). Graphis Scripta 27: 37-41.

Ali, J. R. \& Aitchison, J. C. 2014. Exploring the combined role of eustasy and oceanic island thermal subsidence in shaping biodiversity on the Galapagos. Journal of Biogeography 41: 1227-1241.

Aptroot, A. 2002. New and interesting lichens and lichenicolous fungi in Brazil. Fungal Diversity 9: 15-45.

Aptroot, A. 2015. Holarctic and Caribbean crustose lichens collected by López Figueras in Venezuela. Glalia 7: 1-18.

Aptroot, A. \& Cáceres, M. E. S. 2016. Two new lecanoroid Caloplaca (Teloschistaceae) species from gneiss inselbergs in equatorial Brazil, with a key to tropical lecanoroid species of Caloplaca s.lat. The Lichenologist 48: 201-207.

Arup, U. 1992a. Caloplaca marina and C. rosei, two difficult species in North America. The Bryologist 95: 148-160.

Arup, U. 1992b. Caloplaca stantonii sp. nov. and its relationship to Caloplaca bolacina and other lobate to squamulose species in North America. The Bryologist 95: 449-457.

Arup, U. \& Ekman, S. 1992. Nyheter i södra Sveriges lavflora. Graphis Scripta 4: 81-86.

Arup. U. 1993a. Caloplaca luteominia and C. bolanderi in western North America. The Bryologist 96: 463-470.

Arup, U. 1993b. Caloplaca flavogranulosa sp. nov. and C. citrina, two sorediate species on seashore rocks in Western North America. The Bryologist 96: 598-603.

Arup, U. 1994. The genus Caloplaca on seashore rocks in Eastern North America. The Bryologist 97: 377-392.
Arup, U. 1995a. Eight species of Caloplaca in Western North America. The Bryologist 98: 92-111.

Arup, U. 1995b. Littoral species of Caloplaca in North America: A summary and a key. The Bryologist 98: 129-140.

Arup, U. 2006. A new taxonomy of the Caloplaca citrina group in the Nordic countries, except Iceland. The Lichenologist 38: 1-20.

Arup, U. 2006. A new taxonomy of the Caloplaca citrina group in the Nordic countries, except Iceland. The Lichenologist 38: 1-20.

Arup, U. \& van den Boom, P. 2011. Three new dark-fruited Caloplaca species from Cape Verde. Bibliotheca Lichenologica 106: 1-6.

Arup, U., Søchting, U. \& Frödén, P. 2013a. A new taxonomy of the family Teloschistaceae. Nordic Journal of Botany 31: 16-83.

Arup, U., Søchting, U. \& Frödén, P. 2013b. Addendum to 'A new taxonomy of the family Teloschistaceae'. Nordic Journal of Botany 31: 256.

Bungartz, F., Hillmann, G., Kalb, K. \& Elix, J. A. 2013. Leprose and leproid lichens of the Galapagos with a particular focus on Lepraria (Stereocaulaceae) and Septotrapelia (Pilocarpaceae). Phytotaxa 150: 1-28.

Bungartz, F., Elix, J. A. \& Printzen, C. 2020. Lecanoroid lichens in the Galapagos Islands: the genera Lecanora, Protoparmeliopsis, and Vainionora (Lecanoraceae, Lecanoromycetes). Phytotaxa 431: $1-85$.

Bungartz, F., Elix, J. A., Yánez-Ayabaca, A. \& Archer, A. W. 2015. Endemism in the genus Pertusaria (Pertusariales, lichenized Ascomycota) from the Galapagos Islands. Telopea 18: 325-369.

Bungartz, F., Lücking, R. \& Aptroot, A. 2010. The lichen family Graphidaceae in the Galapagos Islands. Nova Hedwigia 90(1-2): 1-44.

Bungartz, F., Ziemmeck, F., Yánez-Ayabaca Ayabaca, A., Nugra, F. \& Aptroot, A. 2016. CDF Checklist of Galapagos Lichenized Fungi. In: Bungartz, F., Herrera, H., Jaramillo, P., Tirado, N., Jímenez-Uzcategui, G., Ruiz, D., Guézou, A. \& Ziemmeck, F. (eds) Charles Darwin Foundation Galápagos Species Checklist. Puerto Ayora, Charles Darwin Foundation. http://www.darwinfoundation. org/datazone/checklists/ecological-groups/lichens/ [Last updated 29 December 2016]

Darriba, D., Taboada, G. L., Doallo, R. \& Posada, D. 2012. jModelTest 2: more models, new heuristics and parallel computing. Nature Methods 9: 772 .

Dix, W. L. 1953. Some Peruvian lichens. The Bryologist 56: 277-278.

Dodge, C. W. 1936. Lichens of the G. Allan Hancock Expedition of 1934, collected by Wm. R. Taylor. Hancock Pacific Expeditions 3: $33-46$.

Dodge, C. W. 1966. New lichens from Chile. Nova Hedwigia 12: 307-352.

Döring, H., Clerc, P., Grube, M. \& Wedin, M. 2000. Mycobiont specific PCR primers for the amplification of nuclear ITS and LSU rDNA from lichenized ascomycetes. The Lichenologist 32: 200-204.

Elix, J. A. \& McCarthy, P. M. 1998. Catalogue of the Lichens of the Smaller Pacific Islands. Bibliotheca Lichenologica 70: 1-361.

Etayo, J. \& Osorio, H. S. 2004. Algunos hongos liquenícolas de Sudamérica, especialmente del Uruguay. Comunicaciones Botánicas Museos Nacionales de Historia Natural y Antropologia 6: 1-19.

Follmann, G. \& Redon, J. 1972. Ergänzungen zur Flechtenflora der nordchilenischen Nebeloasen Fray Jorge und Talinay. Willdenowia 6: $431-460$.

Frödén, P., Ryan, B. D. \& Kärnefelt, I. 2004. Teloschistes. In: Nash III, T. H., Ryan, B. D., Diederich, P., Gries, C. \& Bungartz, F. (eds) Lichen Flora of the Greater Sonoran Desert Region. Volume 2, pp. 524-529. Arizona State University, Tempe, Arizona.

Fryday, A. M. \& Øvstedal, D. O. 2012. New species, combinations and records of lichenized fungi from the Falkland Islands (Islas Malvinas). The Lichenologist 44: 483-500. 
Gardes, M. \& Bruns, T. D. 1993. ITS primers with enhances specificity for basidiomycetes. Application for the identification of mycorrhizae and rusts. Molecular Ecology 2: 113-118.

Gaya, E., Högnabba, F., Holguin, Á., Molnar, K., Fernández-Brime, S., Stenroos, S., Arup, U., Søchting, U., van den Boom, P., Lücking, R., Sipman, H. J. M. \& Lutzoni, F. 2012. Implementing a cumulative supermatrix approach for a comprehensive phylogenetic study of the Teloschistales (Pezizomycotina, Ascomycota). Molecular Phylogenetics and Evolution 63: 374-387.

Geist, D. 1996. On the emergence and submergence of the Galapagos Islands. Noticias de Galápagos 56: 5-9.

Geist, D., Snell, H., Snell, H., Goddard, C. \& Kurz, M. 2014. Paleogeography of the Galapagos Islands and biogeographical implications. In: Harpp, K., Mittelstaedt, E., d'Ozouville, N. \& D. Graham (eds) The Galapagos: a natural laboratory for the Earth Sciences, pp. 145-166. American Geophysical Union Monograph, Washington.

Guindon, S. \& Gascuel, O. 2003. A simple, fast, and accurate algorithm to estimate large phylogenies by maximum likelihood. Systematic Biology 52: 696-704.

Kondratyuk, S. Y., Kärnefelt, I., Elix, J. A. \& Thell, A. 2007. New species of the genus Caloplaca in Australia. Bibliotheca Lichenologica 95: 341-386.

Kondratyuk, Y. S., Lökös, L., Kim, J. A. Kondratyuk, A. S., Jeong, M. H., Jang, S. H., Oh, S.-O. \& Hur, J.-S. 2015. Three new monotypic genera of the caloplacoid lichens (Teloschistaceae, lichen-forming Ascomycetes). Mycobiology 43: 195-202.

Kondratyuk, S. Y., Lőkös, L., Upreti, D. K., Nayaka, S., Mishra, G. K., Ravera, S., Jeong, M.-H., Jang, S.-H., Park, J. S. \& Hur, J. S. 2017. New monophyletic branches of the Teloschistaceae (lichen-forming Ascomycota) proved by three gene phylogeny. Acta Botanica Hungarica 59: 71-136.

Kärnefelt, E. I., Kondratyuk, S., Søchting, U., Frödén, P. \& Arup, U. 2002. Two new species of Caloplaca (Teloschistaceae) from the Southern Hemisphere. The Bryologist 105: 301-309.

Laundon, J. R. 1974. Leproplaca in the British Isles. The Lichenologist 6: $102-105$.

Lumbsch, H. T., Ahti, T., Altermann, S., Amo De Paz, G., Aptroot, A., Arup, U., Bárcenas Peña, A., Bawingan, P. A., Benatti, M. N., Betancourt, L., Björk, C. R., Boonpragob, K., Brand, M., Bungartz, F., Cáceres, M. E. S., Candan, M., Chaves, J. L., Clerc, P., Common, R., Coppins, B. J., Crespo, A., Dal Forno, M., Divakar, P. K., Duya, M. V., Elix, J. A., Elvebakk, A. V., Fankhauser, J., Farkas, E., Ferraro, I. L., Fischer, E., Galloway, D. J., Gaya, E., Giralt, M., Goward, T., Grube, M., Hafellner, J., Hernández M., J. E., De Los Ángeles Herrera Campos, M., Kalb, K., Kärnefelt, I., Kantvilas, G., Killmann, D., Kirika, P., Knudsen, K., Komposch, H., Kondratyuk, S., Lawrey, J. D., Mangold, A., Marcelli, M. P., Mccune, B., Messuti, M. I., Michlig, A., Miranda Gonzáles, R., Moncada, B., Naikatini, A., Nelsen, M. P., Øvstedal, D. O., Palice, Z., Papong, K., Parnmen, S., Pérez-Ortega, S., Printzen, C., Rico, V. J., Robayo, J., Rosabal, D., Ruprecht, U., Salazar Allen, N., Sancho, L., Santos De Jesus, L., Santos Vieira, T., Schultz, M., Seaward, M. D. R., Sérusiaux, E., Schmitt, I., Sipman, H. J. M., Sohrabi, M., Søchting, U., Søgaard, M. Z., Sparrius, L. B., Spielmann, A., Spribille, T., Sutjaritturakan, J., Thammathaworn, A., Thor, G., Thüs, H., Timdal, E., Truong, C., Türk, R., Umaña Tenorio, L., Upreti, D. K., Van Den Boom, P., Vivas Rebuelta, M., Wedin, M., Will-Wolf, S., Wirth, V., Wirtz, N., Yahr, R., Yeshitela, K., Ziemmeck, F. \& Lücking, R. 2011. One hundred new species of lichenized fungi: a signature of undiscovered global diversity. Phytotaxa 18: 1-127.

Magnusson, A. H. 1950. Lichens from Uruguay. Meddelanden från Göteborgs Botaniska Trädgård. 18: 213-237.

May, T. W., Redhead, S. A., Bensch, K., Hawksworth, D. L., Lendemer, L., Lombard, L. \& Turland, N. 2019. Chapter F of the International Code of Nomenclature for algae, fungi, and plants as approved by the 11th International Mycological Congress, San Juan, Puerto Rico, July 2018. IMA Fungus 10: 21.

McCarthy, P. M. 2016. Checklist of the Lichens of Australia and its Island Territories. Australian Biological Resources Study, Canberra.
Version 22 January 2016. http://www.anbg.gov.au/abrs/lichenlist/ introduction.html

Ronquist, F., Teslenko, M., van der Mark, P., Ayres, D. L., Darling, A., Höhna, S., Larget, B., Liu, L., Suchard, M. A. \& Huelsenbeck, J. P. 2012. MrBayes 3.2: Efficient Bayesian phylogenetic inference and model choice across a large model space. Systematic Biology 61: 539-542.

Rosato, V. G. \& Arup, U. 2010. Caloplaca austrocitrina (Teloschistaceae) new for South America, based on molecular and morphological data. The Bryologist 113: 124-128.

Santesson, J. 1970. Anthraquinones in Caloplaca. Phytochemistry 9: 2149-2166.

Santesson, R. 1944. Contributions to the lichen flora of South America. Arkiv för Botanik 31A: 1-28.

Snell, H. M., Stone, P. A. \& Snell, H. L. 1995. Geographical characteristics of the Galapagos Islands. Noticias de Galápagos 55: 18-24.

Snell, H. M., Stone, P. A. \& Snell, H. L. 1996. A summary of geographical characteristics of the Galapagos Islands. Journal of Biogeography 23: 619-624.

Schumm, F. \& Aptroot, A. 2019a. Images of the lichen genus Caloplaca. Volume 1. Caloplaca adelphoparasitica - Caloplaca crenularia. Books on Demand, Norderstedt.

Schumm, F. \& Aptroot, A. 2019b. Images of the lichen genus Caloplaca. Volume 2. Caloplaca crenularia-Caloplaca holocarpa. Books on Demand, Norderstedt.

Schumm, F. \& Aptroot, A. 2019c. Images of the lichen genus Caloplaca. Volume 3. Caloplaca holocarpa-Caloplaca pulicarioides. Books on Demand, Norderstedt.

Søchting, U. 1997. Two major anthraquinone chemosyndromes in Teloschistaceae. Bibliotheca Lichenologica 86: 135-144.

Søchting, U. 2001. Chemosyndromes with chlorinated anthraquinones in the lichen genus Caloplaca. Bibliotheca Lichenologica 78: 395-404.

Søchting, U. \& Frödén, P. 2002. Chemosyndromes in the genus Teloschistes (Teloschistaceae, Lecanorales). Mycological Progress 1: 257-266.

Søchting, U. \& Sancho, L. G. 2012. Caloplaca magellanica sp. nova, a southern Patagonian parasite on Zahlbrucknerella. Bibliotheca Lichenologica 108: 215-220.

Søchting, U., Søgaard, M. Z., Elix, J. A., Arup, U., Elvebakk, A. \& Sancho, L. G. 2014. Catenarina (Teloschistaceae, Ascomycota), a new Southern Hemisphere genus with 7-chlorocatenarin. The Lichenologist 46: 175-187.

Søchting, U., Søgaard, M. Z., Sancho, L. G., Frödén, P. \& Arup, U. 2016. Sirenophila ovis-atra a new species of maritime Teloschistaceae from the Southern Hemisphere. Opuscula Philolichenum 15: 1-5.

Stewart, A. 1912. Expedition of the California Academy of Sciences to the Galapagos Islands 1905-1906. No. 7: Notes on the Lichens of the Galapagos Islands. Proceedings of the Californian Academy of Sciences, 4th Series 1: 431-446.

Trueman, M. \& d'Ozouville, N. 2010. Characterizing the Galapagos terrestrial climate in the face of global climate change. Galapagos Research 67: 26-37.

Tucker, S. C. 1979. New or noteworthy records of lichens from Louisiana. The Bryologist 82: 125-140.

Tuckerman, E. 1862. Observations on North American and other lichens (Continued from Vol. IV. p. 407). Proceedings of the American Academy of Arts and Sciences 5: 383-422.

Tye, A. \& Francisco-Ortega, J. 2011. Origins and evolution of Galapagos endemic vascular plants. In: Bramwell, D. \& Caujapé-Castells, J. (eds) The Biology of Island Floras, pp. 89-153. Cambridge University Press, Cambridge.

Tye, A., Snell, H. L., Peck, S. B. \& Adsersen, H. 2002. Outstanding terrestrial features of the Galapagos Archipelago. In: Bensted-Smith, R. (ed.) A biodiversity vision for the Galapagos Islands, pp. 25-35. Charles Darwin Foundation and World Wildlife Fund, Puerto Ayora.

Vainio, E. A. 1890. Étude sur la classification et la morphologie des lichens du Brésil, I. Acta Soc. pro Fauna et Flora Fennica 7: 1-247. 
Vainio, E. A. 1896. Lichenes Antillarum a W. R. Elliot collecti. The Journal of Botany 34: 66-72.

Vilgalys, R. \& Hester, M. 1990. Rapid genetic identification and mapping of enzymatically amplified ribosomal DNA from several Cryptococcus species. Journal of Bacteriology 172: 4239-4246.

Weber, W. A. 1966. Lichenology and bryology in the Galápagos Islands, with checklists of the lichens and bryophytes thus far reported. In: Bowman, R. I. (ed.) The Galápagos, pp. 197-200. Proceedings of the Symposium of the Galápagos International Scientific Project. University of California Press, Berkeley.

Weber, W. A. 1986. The lichen flora of the Galapagos Islands, Ecuador. Mycotaxon 27: 451-497.

Wetmore, C. M. \& Kärnefelt, E. I. 1998. The lobate and subfruticose species of Caloplaca in north and central America. The Bryologist 101: 230-255.

Wetmore, C. M. \& Kärnefelt, E. I. 1999. [2000] What is Caloplaca cinnabarina? The Bryologist 102: 683-691.

Wetmore, C. M. 1994. The lichen genus Caloplaca in North and Central America with brown or black apothecia. Mycologia 86: 813-838.

Wetmore, C. M. 1996. The Caloplaca sideritis group in North and Central America. The Bryologist 99: 292-314.

Wetmore, C. M. 1997. The typification of Caloplaca chlorina. The Bryologist 100: 170.

Wetmore, C. M. 1999. Four new species of Caloplaca from Mexico. The Bryologist 102: 99-103.

Wetmore, C. M. 2001. The Caloplaca citrina group in North and Central America. The Bryologist 104: 1-11.
Wetmore, C. M. 2003. The Caloplaca squamosa group in North and Central America. The Bryologist 106: 147-156.

Wetmore, C. M. 2004. The isidiate corticolous Caloplaca species in North and Central America. The Bryologist 107: 284-292.

Wetmore, C. M. 2007a. Caloplaca. In: Nash III, T. H., Gries, C. \& Bungartz, F.: Lichen Flora of the Greater Sonoran Desert Region. Volume 3. Arizona State University, Tempe, p. 179-220.

Wetmore, C. M. 2007b. Notes on Caloplaca cerina (Teloschistaceae) in North and Central America. The Bryologist 110: 798-807.

Wetmore, C. M. 2009. New species of Caloplaca (Teloschistaceae) from North America. The Bryologist 112: 379-386.

White, T. J., Bruns, T. D., Lee, S. \& Taylor, J. 1990. Application and direct sequencing of fungal ribosomal DNA for phylogenetics. In: Innis, M. A., Gelfand, D. H., Sninsky, J. J. \& White, T. J. (eds) PCR protocols: a guide to methods and applications, pp. 315-322. Academic Press, San Diego.

Wilk, K. 2020. Huriella flakusii (Teloschistaceae, lichenized Ascomycota), a new species from the Colca Canyon region in Peru. The Lichenologist 52: 37-47.

Wilk, K. \& Flakus, A. 2017. Eight Caloplaca species newly recorded from Bolivia, including C. crocina comb. nov. Mycotaxon 132: 125-140.

Zoller, S., Scheidegger, C. \& Sperisen, C. 1999. PCR primers for the amplification of mitochondrial small subunit ribosomal DNA of lichen- forming ascomycetes. The Lichenologist 31: 511-516.

Zhou, S. \& Stanosz, G. R. 2001. Primers for amplification of mt SSU rDNA, and a phylogenetic study of Botryosphaeria and associated anamorphic fungi. Mycological Research 105: 1033-1044. 